\title{
RESERVAS ORGÂNICAS, ÍNDICE DE ÁREA FOLIAR E PRODUÇÃO DE FORRAGEM EM Brachiaria brizantha cv. Marandu SUBMETIDA A INTENSIDADES DE PASTEJO POR BOVINOS DE CORTE
}

\author{
Adriano VecChiatti LUPinacCi
}

Dissertação apresentada à Escola Superior de Agricultura "Luiz de Queiroz", Universidade de São Paulo, para obtenção do título de Mestre em Agronomia, Área de Concentração: Ciência Animal e Pastagens.

P I R A C I C A B A

Estado de São Paulo - Brasil

Maio - 2002 


\title{
RESERVAS ORGÂNICAS, ÍNDICE DE ÁREA FOLIAR E PRODUÇÃO DE FORRAGEM EM Brachiaria brizantha cv. Marandu SUBMETIDA A INTENSIDADES DE PASTEJO POR BOVINOS DE CORTE
}

\author{
Adriano Vecchiatti Lupinacci \\ ENGENHEIRO AGRÔNOMO
}

Orientador: Prof. Dr. SILA CARNEIRO DA SILVA

Dissertação apresentada à Escola Superior de Agricultura "Luiz de Queiroz", Universidade de São Paulo, para obtenção do título de Mestre em Agronomia, Área de Concentração: Ciência Animal e Pastagens.

P I R A C I C A B A

Estado de São Paulo - Brasil

Maio - 2002 


\title{
Dados Internacionais de Catalogação na Publicação (CIP) DIMSÃO DE BIBLIOTECA E DOCUMENTAÇÃO - ESALQ/USP
}

\author{
Lupinacci, Adriano Vecchiatti \\ Reservasorgânicas, índice de área foliare produção de forragem em \\ Brachiaria brizantha cv. Marandu submetida a intensidades de pastejo por \\ bovinos de corte / Adriano Vecchiatti Lupinacci. - - Piracicaba, 2002. \\ 160 p. : il. \\ Dissertação (mestrado) - - Escola Superior de Agricultura Luiz de \\ Queiroz, 2002. \\ Bibliografia. \\ 1. Bovinos de corte 2. Capim braquiária 3. Crescimento vegetal 4. \\ Forragem 5. Nutrição vegetal 6. Pastejo (Manejo) 7. Plantas cultivadas \\ (Fisiologia) I. Título
}

CDD 633.2

\section{"Permitida a cópia total ou parcial deste documento, desde que citada a fonte - O autor"}




\section{DEDICO}

Aos meus pais Ronaldo e Eunice, pelo exemplo de vida, amor e confiança Às minhas irmãs Patrícia e Isabella pela convivência sempre harmoniosa Às minhas queridas avós, Lica e Luzia pelo amor e incentivo constante Aos meus tios Alberto e Rosângela pela hospitalidade e incentivo À querida Daniela pela amizade, amor e companheirismo

\section{MINHA ETERNA GRATIDÃO}

\section{OFEREÇO}

Ao meu orientador Sila Carneiro da Silva, pelo pioneirismo e coragem próprios dessa linha de pesquisa e conduta - científica e profissional - exemplar

Ao meu grande "mestre" Alexandre de Oliveira Barcellos, pelos ensinamentos, constante incentivo e profissionalismo insólito

Ao amigo André Fisher Sbrissia, pela admirável dedicação à causa científica e como estímulo pelo árduo trabalho.

Ao meu avô Petrus Tulius (in memorian) pelo maior exemplo MINHA HOMENAGEM 
Aos amigos do GEPF: se algum sucesso houver, este deverá ser compartilhado com àqueles que sempre estiveram ao meu lado nesta árdua, mas

gratificante caminhada.

Um conforto: "sei que meu trabalho é uma gota no oceano. Mas sem ele, o oceano seria menor." (Madre Teresa de Calcutá)

"A mente que se abre a uma nova idéia jamais voltará ao seu tamanho original".

(Albert Einstein)

Aos pioneiros: “... lembre-se sempre de que o primeiro cão de neve que puxa o trenó é o único que desfruta de uma vista decente...”. (Leonardo Boff)

"Cada pessoa em sua existência pode ter duas atitudes: construir ou plantar.

Os construtores podem demorar anos em suas tarefas, mas um dia terminam aquilo que começaram. Então param e ficam limitados por suas próprias paredes. A vida perde o sentido quando a construção acaba.

Mas existem os que plantam. Estes, às vezes sofrem com as tempestades, com as intempéries e, raramente descansam. Mas, ao contrário de um edifício, o Jardim jamais pára de crescer. E, ao mesmo tempo em que exige a atenção do jardineiro, permite que, para ele, a vida seja um grande desafio.

Os jardineiros se reconhecerão entre si, porque sabem que na história de cada planta está o crescimento de Toda Terra". (Paulo Coelho) 


\section{AGRADECIMENTOS}

Ao Professor Dr. Sila Carneiro da Silva, orientador exemplar e distinto, pela oportunidade ímpar, paciência, dedicação contagiante, amizade e confiança em mim.

Aos membros, pós-graduandos, do Grupo de Estudos de Plantas Forrageiras (GEPF), Alexandre Gonçalves, Daniel Sarmento, Flávia de Andrade e Leonardo Molan pelo apoio, nas alegrias e dissabores ao longo da condução do experimento, sem o qual seria impossível a realização deste gratificante trabalho. Em especial, ao doutorando André Fischer Sbrissia pela serenidade, incentivo, amizade e colaboração inestimáveis.

Aos estagiários do Grupo de Estudos de Plantas Forrageiras (GEPF): Érica Rodrigues, Luciano Piza, Érica Nakandare, Felipe Barreto, Alexandre Mariano, Fábio Caminha, Artur Siqueira, Diego da Silva, Lilian Bellucci, Tiago Palma, Victor Hugo, Alexandra Lupo, Danilo Kashiwakuara e, especialmente, aos estudantes Cauê Varesqui Zeferino e Vitor Braga Pereira de Carvalho, por terem confiado em mim desde o início desta árdua empreitada. A todos vocês, pelo empenho e dedicação, meu mais profundo agradecimento.

À Eng ${ }^{\mathrm{a}}$. Agr ${ }^{\mathrm{a}}$. Daniela Moreira Kubiak pela dedicação, amizade, companheirismo e presença nos momentos difíceis, que a tornam muito especial.

Ao grande amigo Eng ${ }^{\circ}$. Agr ${ }^{\circ}$. Fábio Henrique Rojo Baio, com quem dividi parte do tempo e espaço, pela valiosa amizade desde a graduação.

Aos primos Nando, Ricardo e Tuia pela amizade e convivência harmoniosa.

Aos Professores Dr. Vidal Pedroso de Faria e Dr. Wilson Roberto Soares Mattos pelo exemplo de dedicação profissional e convivência enriquecedora.

Aos Professores Dr. Luiz Gustavo Nussio e Dr. Flávio Augusto Portela Santos, pela oportunidade de uso do Laboratório de Bromatologia do Departamento de Produção Animal da USP/ESALQ e pela concessão dos animais utilizados no experimento, respectivamente.

Ao Professor Dr. Carlos Guilherme Silveira Pedreira pelas valiosas sugestões dadas ao longo do curso e, sobremaneira, durante a elaboração deste documento. 
Ao Professor Dr. Quirino Carmello pela solicitude constante e concessão de parte do material de laboratório usado nas análises.

Ao Professor Dr. Valdo Rodrigues Herling, da Faculdade de Zootecnia e Engenharia de Alimentos (USP/FZEA), pelo treinamento concedido.

Aos funcionários do Departamento de Produção Animal, Creide, Carlos, Juscelino, Émerson, Laureano, Benedito, César e Renato, pela constante solicitude.

Aos colegas Paulo Sérgio, Tadeu, Junio César, Lirís, Décio, Rafael, Vicente, Henrique Rocha, Felipe, Lyssa, Carolina, Raquel, Liliane, Maurício, Rosane e Fábio Maya pela amizade. Em especial aos amigos Francisco Dias, Hugo Imaizumi, Marina Uebele e Roberta Carnevalli, Marco Jacomazzi, Cláudio Franco e Adriano Borges.

Aos pesquisadores da EMBRAPA Cerrados, Alexandre de Oliveira Barcellos, Lourival Vilela, Ronaldo de Andrade, Gilberto Leite, Wilson Soares, Cláudio Karia, Marcelo Ayres e Marco Antônio de Souza (in memorian), pelos ensinamentos e contribuição fundamental para minha formação profissional.

Ao Chefe Geral da EMBRAPA Cerrados, Carlos Magno Campos da Rocha por todas as oportunidades cedidas durante minha estada nesse centro de pesquisa.

Ao pesquisador da EMBRAPA Gado de Corte, Manuel Cláudio Motta Macedo e, aos amigos Allan Kardec e Luis Gustavo Barioni pelo incentivo e valiosas sugestões.

Ao Professor e pesquisador José Guilherme Nascimento Neto e Dr. José Carlos Chitolina, que ao longo do curso técnico em Agropecuária e durante a graduação, respectivamente, foram os primeiros que me incentivaram na pesquisa científica.

Aos Professores Dr. Jean Avice, da Université de Caen, Dr. Jeffrey Volenec, da Purdue University, Dr. Peter Millard e Dr. Barry Thornton, do Macaulay Land Research Institute, pelos valiosos textos e comentários sobre reservas orgânicas.

À Escola Superior de Agricultura "Luiz de Queiroz", pela oportunidade única de formação profissional, tanto durante a graduação quanto neste momento.

À Fundação de Coordenação de Aperfeiçoamento de Pessoal de Nível Superior (CAPES) e à Fundação de Amparo à Pesquisa do Estado de São Paulo (FAPESP), pela concessão da bolsa de estudo e, a essa última, também pelo financiamento deste projeto. 


\section{SUMÁRIO}

Página

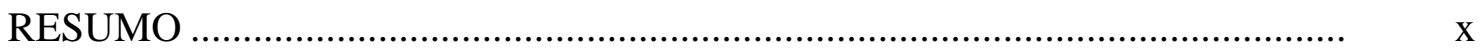

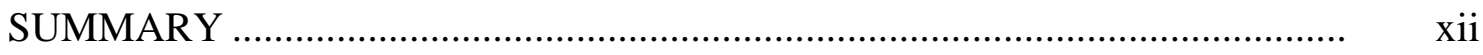

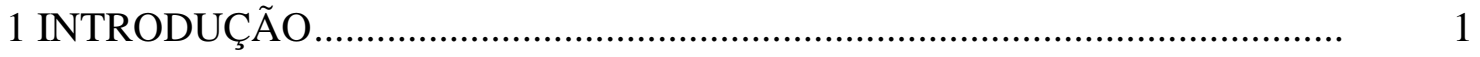

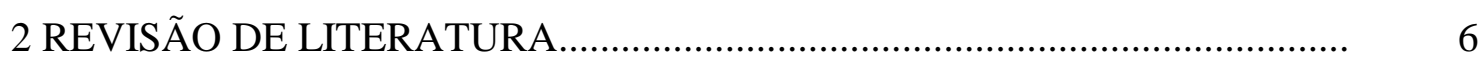

2.1 Importância da manutenção de um estado de equilíbrio do pasto em estudos

de ecofisiologia de pastagens .............................................................. 6

2.2 Espécie forrageira: Brachiaria brizantha $\mathrm{cv}$. Marandu ................................. 9

2.3 Respostas das plantas forrageiras ao processo de desfolha ............................ 12

2.3.1 Índice de área foliar (IAF): definição .................................................... 14

2.3.1.1 IAF e aspectos fisiológicos da produção de forragem .............................. 16

2.3.1.2 IAF em plantas forrageiras tropicais: resultados de pesquisa...................... 18

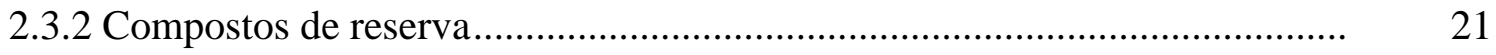

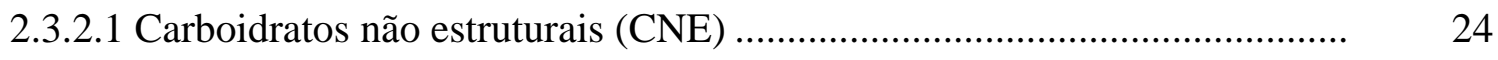

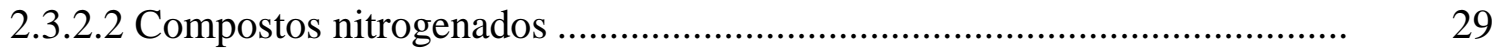

2.4 Área foliar e compostos de reserva: implicações no manejo do pastejo .......... 34

2.4.1 Lotação contínua e lotação intermitente .................................................. 34

2.4.2 Princípios de manejo do pastejo ........................................................... 37

3 MATERIAL E MÉTODOS .....................................................................

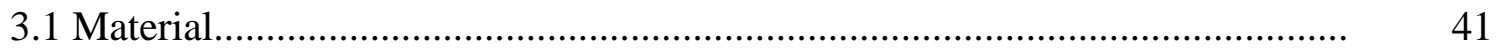

3.1.1 Espécie vegetal .......................................................................... 41

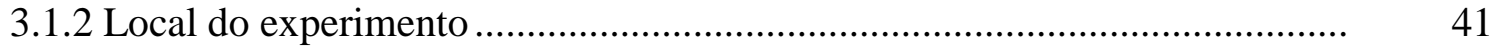

3.1.3 Solo da área experimental .............................................................. 42 


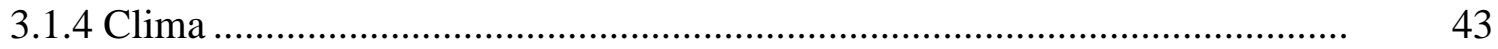

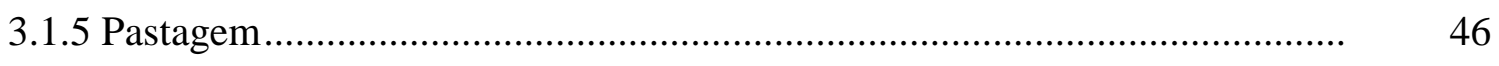

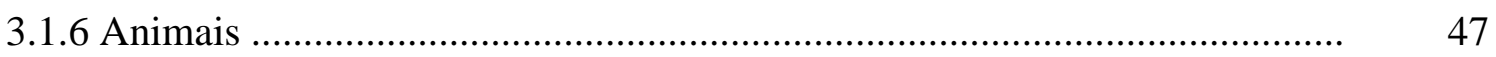

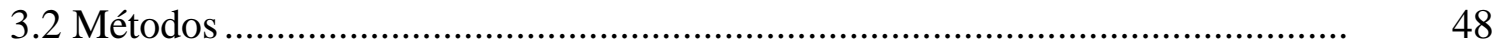

3.2.1 Delineamento experimental e tratamentos .................................................... 48

3.2.2 Instalação e monitoramento das condições experimentais ............................. 49

3.2.3 Calibração: altura x massa............................................................................ 51

3.2.4 Acúmulo de forragem ........................................................................ 52

3.2.5 Distribuição relativa da ocupação do solo nas unidades experimentais........ 53

3.2.6 Índice de área foliar (IAF) do pasto............................................................. 53

3.2.7 Coleta de amostras para determinação de massa de raízes e parte aérea e teores de compostos de reserva .................................................................. 54

3.2.7.1 Amostragem e amostras ......................................................................... 54

3.2.7.2 Determinação da massa de raízes e de parte aérea ....................................... $\quad 56$

3.2.7.3 Determinação dos teores de compostos de reserva .................................... 57

3.2.7.3.1 Carboidratos não estruturais ................................................................ 57

3.2.7.3.2 Compostos nitrogenados ................................................................... 57

3.2.7.3.2.1 Determinação do nitrogênio total $(\mathrm{N}$ total)............................................. 57

3.2.7.3.2.2 Determinação do nitrogênio protéico solúvel ( $\mathrm{N}$ solúvel)..................... 58

3.2.7.3.2.3 Determinação do nitrogênio em aminoácidos ( $\mathrm{N}$ aminoácidos) ........... 58

3.2.7.3.2.4 Determinação do amônio $\left(\mathrm{NH}_{4}{ }^{+}\right)$e nitrato $\left(\mathrm{NO}_{3}{ }^{-}\right)$................................ 58

3.2.7.4 Determinação do nitrogênio total ( $\mathrm{N}$ total) em folhas ................................... 58

3.2.8 Análise estatística dos dados ....................................................................... 59

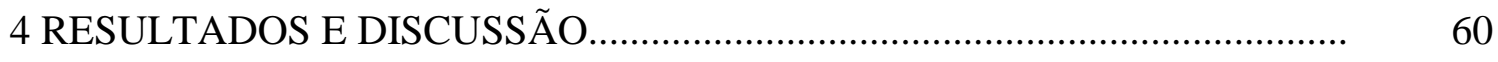

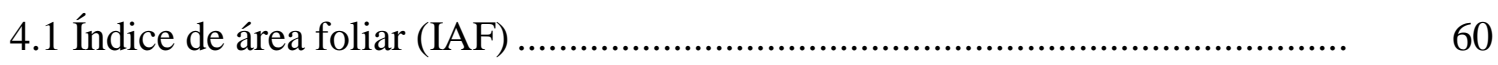

4.2 Massa de raízes e de parte aérea..................................................................... 65

4.3 Compostos de reserva.............................................................................. 71

4.3.1 Carboidratos não estruturais (CNE) …………………………………....... 71

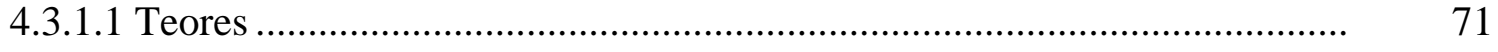

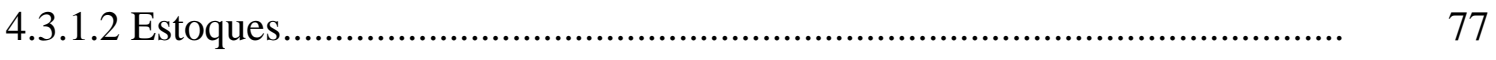




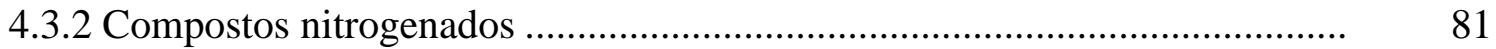

4.3.2.1 Nitrogênio total $(\mathrm{N}$ total) ………………………................................. 81

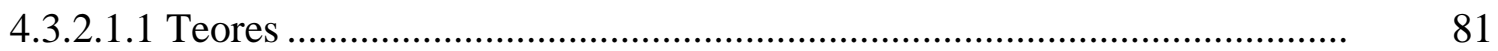

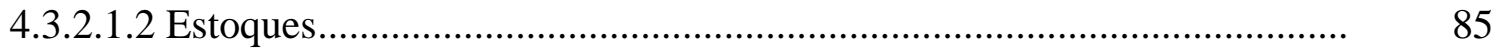

4.3.2.2 Nitrogênio solúvel ( $\mathrm{N}$ solúvel) ...............................................................

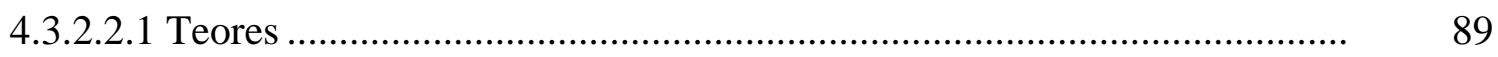

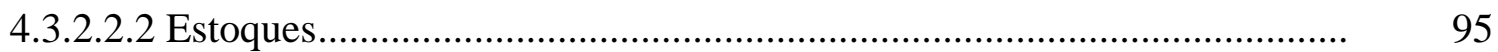

4.3.2.3 Nitrogênio em aminoácidos ( $\mathrm{N}$ aminoácidos) ............................................ 100

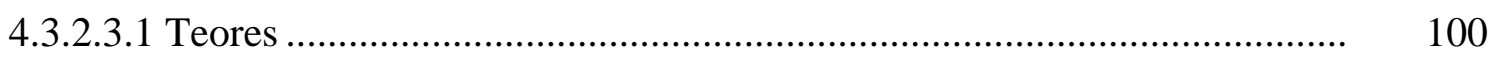

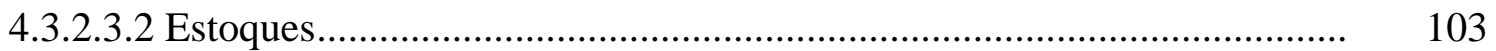

4.3.2.4 Amônio $\left(\mathrm{NH}_{4}{ }^{+}\right)$.................................................................................

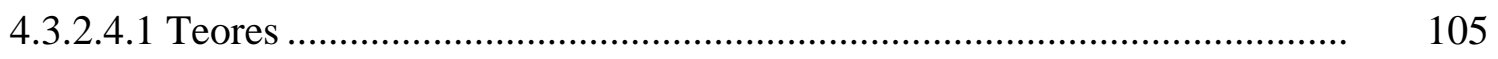

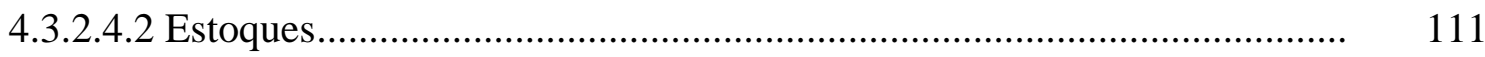

4.3.2.5 Nitrato $\left(\mathrm{NO}_{3}{ }^{-}\right)$.............................................................................

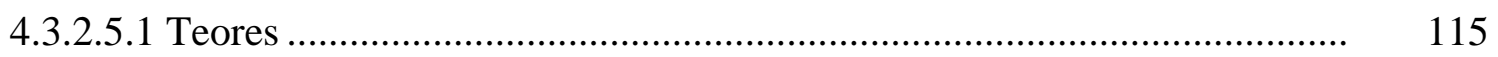

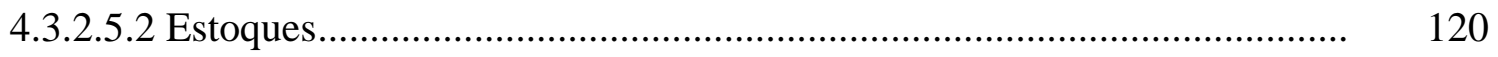

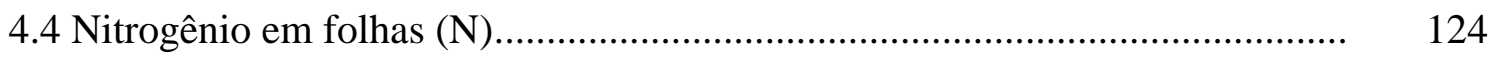

4.5 Taxa de acúmulo e acúmulo de forragem...................................................... 128

4.6 Considerações Finais ................................................................................. 134

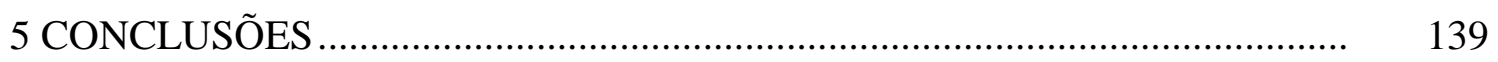

REFERÊNCIAS BIBLIOGRÁFICAS.......................................................... 140

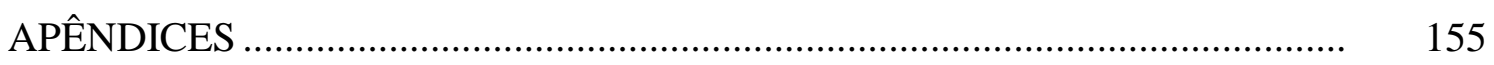




\title{
RESERVAS ORGÂNICAS, ÍNDICE DE ÁREA FOLIAR E ACÚMULO DE FORRAGEM EM Brachiaria brizantha cv. Marandu SUBMETIDA A INTENSIDADES DE PASTEJO POR BOVINOS DE CORTE
}

\author{
Autor: ADRIANO VECCHIATTI LUPINACCI \\ Orientador: Prof. Dr. SILA CARNEIRO DA SILVA
}

\section{RESUMO}

As áreas de pastagens no Brasil ocupam cerca de 180 milhões de hectares, que são responsáveis por cerca de $90 \%$ da carne bovina produzida no país. No entanto, em torno de $80 \%$ das pastagens cultivadas apresentam algum grau de degradação, sendo este apontado como o maior problema relacionado com a sustentabilidade da produção animal em pastagens. Uma das principais razões para esse fato está relacionada a erros grosseiros no manejo das pastagens, conseqüência do desconhecimento dos limites ecofisiológicos e de resistência ao pastejo das plantas forrageiras. Dentro desse contexto, o objetivo deste experimento foi determinar quantitativamente o índice de área foliar, os teores e estoques de carboidratos não estruturais e frações nitrogenadas ( $\mathrm{N}$ total, $\mathrm{N}$ solúvel, $\mathrm{N}$ aminoácidos, $\mathrm{N}$ amônio, $\mathrm{N}$ nitrato) de reserva, a taxa de acúmulo e a produção de forragem em pastos de Brachiaria brizantha cv. Marandu pastejados por bovinos em regime de lotação contínua e taxa de lotação variável. O experimento foi realizado em área do Departamento de Produção Animal da USP/ESALQ, em Piracicaba, SP, entre 27 de agosto de 2001 e 28 de fevereiro de 2002. Os tratamentos corresponderam a quatro alturas de pasto $(10,20,30$ e $40 \mathrm{~cm})$, mantidas em steady state, e foram alocados às unidades experimentais conforme um delineamento de blocos completos casualizados, com quatro repetições. Os valores de IAF $(1,7 ; 3,5 ; 4,0$ e 3,8) 
foram crescentes para as alturas de pasto estudadas $(10,20,30$ e $40 \mathrm{~cm}$, respectivamente) e semelhantes para as alturas de 20, 30 e $40 \mathrm{~cm}$. Comportamento semelhante foi identificado para as taxas de acúmulo $(102,0 ; 118,5 ; 121,6$ e 113,9 $\left.\mathrm{kg} \mathrm{ha}^{-1} \mathrm{dia}^{-1} \mathrm{MS}\right)$ e acúmulo total de forragem (10.300; $13.340 ; 12.620$ e $\left.13.880 \mathrm{~kg} \mathrm{ha}^{-1}\right)$. Os teores $\left(88,5 ; 111,7 ; 109,8\right.$ e $\left.118,4 \mathrm{~g} \mathrm{~kg}^{-1}\right)$ e estoques $(0,152 ; 0,167 ; 0,180$ e 0,157 $\left.\mathrm{kg} \mathrm{m}^{-2}\right)$ de carboidratos não estruturais foram crescentes com as alturas de pasto $(10,20$, 30 e $40 \mathrm{~cm}$, respectivamente), ao passo que o inverso foi detectado para os teores e estoques de todas as frações nitrogenadas $\left(10,65 ; 8,93 ; 8,64 ; 8,04 \mathrm{~g} \mathrm{~kg}^{-1} \mathrm{~N}\right.$ total e 0,018 ; 0,$017 ; 0,014 ; 0,012 \mathrm{~kg} \mathrm{~m}^{-2} \mathrm{~N}$ total, respectivamente). Com relação ao meses, houve uma redução acentuada ao longo do período experimental nos teores $\left(118,8\right.$ para $87,2 \mathrm{~g} \mathrm{~kg}^{-1}$ de setembro a fevereiro) e estoques $\left(0,225\right.$ para $0,111 \mathrm{~kg} \mathrm{~m}^{-2}$ de setembro a fevereiro) de carboidratos não estruturais e, também nos teores e estoques correspondentes às frações nitrogenadas (12,76 para 3,98 $\mathrm{g} \mathrm{kg}^{-1} \mathrm{~N}$ total e 0,031 para $0,005 \mathrm{~kg} \mathrm{~m}^{-2} \mathrm{~N}$ total de setembro a fevereiro), motivadas inicialmente pelo início do verão (estação de crescimento) e posteriormente pelo início do desenvolvimento reprodutivo das plantas. Os estoques de carboidratos e de frações nitrogenadas foram consistentemente maiores para a base do colmo relativamente às raízes, tendo sido utilizados como fonte preferencial de matéria prima para o crescimento das plantas, razão pela qual sofreram as maiores reduções ao longo do tempo. As inflorescências se mostraram drenos metabólicos muito fortes durante a fase reprodutiva, assim como os meristemas apicais durante a fase vegetativa. $\mathrm{O}$ teor de $\mathrm{N}$ total nas folhas dos perfilhos diminuiu com $\mathrm{o}$ tempo (17,4 para 13,1 $\mathrm{g} \mathrm{kg}^{-1}$ de dezembro a fevereiro), sendo os valores crescentes para folhas senescentes, maduras e em expansão (11,4, 14,0 e $16,7 \mathrm{~g} \mathrm{~kg}^{-1}$, respectivamente). A altura de pasto de $10 \mathrm{~cm}$ correspondeu a uma condição de desfolha drástica, de modo que o manejo do pastejo deveria ser efetuado entre as condições de pasto de 20 e $40 \mathrm{~cm}$. A escolha da condição de pasto mais indicada deve ser feita mediante o objetivo da atividade e a natureza da exploração animal proposta. 


\title{
ORGANIC RESERVES, LEAF AREA INDEX AND HERBAGE YIELD IN Brachiaria brizantha cv. Marandu SUBMITTED TO GRAZING INTENSITIES BY BEEF CATTLE
}

\author{
Author: ADRIANO VECCHIATTI LUPINACCI \\ Advisor: Prof. Dr. SILA CARNEIRO DA SILVA
}

\section{SUMMARY}

Grassland areas in Brazil occupy around 180 million hectares and support about $90 \%$ of the country's beef production. However, approximately $80 \%$ of the cultivated pasture areas present some degree of degradation, that being the main problem related to the sustainability of pasture-based animal production systems. One of the main reasons for this is the mismanagement of pastures, consequence of the lack of knowledge and understanding about the ecophysiological limits and tolerance to grazing of forage plants. Against this background, the objective of this experiment was to determine the leaf area index (LAI), concentrations and pools of non structural carbohydrates (NSC) and nitrogenous reserve compounds (total $\mathrm{N}$, soluble $\mathrm{N}$, amino acid $\mathrm{N}$, ammonium $\mathrm{N}$, nitrate $\mathrm{N}$ ), herbage dry matter accumulation rates and forage yield from Brachiaria brizantha $\mathrm{cv}$. Marandu pastures continuously stocked by cattle, with variable stocking rate. The experiment was carried out at Departamento de Produção Animal, USP/ESALQ, Piracicaba, SP, from 27 August 2001 until 28 February 2002. Treatments corresponded to four steady state conditions characterized by sward surface heights (SSH) of 10, 20, 30 and $40 \mathrm{~cm}$, assigned to experimental units according to a complete randomized block design, with four replications. LAI values (1.7, 3.5, 4.0 and 3.8) increased with increasing SSH $(10,20,30$ and $40 \mathrm{~cm}$, respectively) and were not 
different among the 20,30 and $40 \mathrm{~cm}$ treatments. Similar trend was recorded for herbage accumulation rates $\left(102.0,118.5,121.6\right.$ and $\left.113.9 \mathrm{~kg} \mathrm{ha}^{-1}\right)$ and forage yield $(10,300$, 13,340, 12,620 and 13,880 $\left.\mathrm{kg} \mathrm{ha}^{-1}\right)$. The concentration (88.5, 111.7, 109.8 and $118.4 \mathrm{~g}$ $\left.\mathrm{kg}^{-1}\right)$ and pool (0.152, 0.167, 0.180 and $0.157 \mathrm{~kg} \mathrm{~m}^{-2}$ ) of NSC increased with increasing SSH (10, 20, 30 and $40 \mathrm{~cm}$, respectively), whereas the inverse occurred with the concentration and pool of all nitrogenous compounds (10.65, 8.93, 8.64 and $8.04 \mathrm{~g} \mathrm{~kg}^{-1}$ total $\mathrm{N}$ and $0.018,0.017,0.014$ and $0.012 \mathrm{~kg} \mathrm{~m}^{-2}$ total $\mathrm{N}$, respectively). In relation to time of the year, there was a sharp decrease in the concentration and pool of NSC throughout the experimental period (118.8 to $87.2 \mathrm{~g} \mathrm{~kg}^{-1}$ and 0.225 to $0.111 \mathrm{~kg} \mathrm{~m}^{-2}$, respectively, from September to February) as well as in the concentration and pool of all nitrogenous compounds (12.76 to $3.98 \mathrm{~g} \mathrm{~kg}^{-1}$ total $\mathrm{N}$ and 0.031 to $0.005 \mathrm{~kg} \mathrm{~m}^{-2}$ total $\mathrm{N}$, respectively, from September to February), initially motivated by the commencement of summer (growing season) and followed by the beginning of reproductive development of plants. Pools of NSC and all nitrogenous compounds stored in stem base were consistently higher than those stored in roots and comprised the prime source of substances for plant growth, that being the reason for presenting the greatest reductions throughout the experimental period. Reproductive stems proved to be very strong metabolic drains during the reproductive phase of plant development as well as tiller growing points during the vegetative phase. The total $\mathrm{N}$ concentration in tiller leaves decreased with time (17.4 to $13.1 \mathrm{~g} \mathrm{~kg}^{-1}$ from December to February), with values increasing for senescent, mature and elongating leaves $\left(11.4,14.0\right.$ and $16.7 \mathrm{~g} \mathrm{~kg}^{-1}$, respectively). The $10 \mathrm{~cm} \mathrm{SSH}$ corresponded to a drastic defoliation condition, indicating that grazing management should be conducted within the 20 to $40 \mathrm{~cm} \mathrm{SSH}$ range. The choice of the most appropriate SSH condition must take into account the main objective and nature of the animal production system proposed. 


\section{INTRODUÇÃO}

As áreas de pastagens no Brasil ocupam cerca de 180 milhões de hectares, ou seja, aproximadamente 20\% do território nacional (IBGE, 1998; FAO, 2002). Perto de $56 \%$ dessas pastagens foram introduzidas através da ação antrópica (IBGE, 1998), principalmente nas últimas quatro décadas, incentivada pela criação do Programa de Desenvolvimento do Centro Oeste (POLOCENTRO) (Macedo, 1995) e do Conselho de Desenvolvimento para a Pecuária (CONDEPE). Estimativas recentes mostram que a metade dessas áreas se encontra nos Cerrados, havendo um consenso de que as áreas de pastagens cultivadas deverão ser expandidas nessa região nos próximos anos, visto que a referida região se destaca como uma das últimas e, talvez, a mais extensa fronteira agrícola do mundo (Macedo, 2000). Esse fato pode ser ratificado pelo crescimento vertiginoso das áreas ocupadas por pastagens cultivadas nos Cerrados, que passaram de 11 milhões de hectares em 1970 para cerca de 50 a 55 milhões de hectares atualmente (Sano et al., 1999), aumento este equivalente a 350\%. Comparativamente, no mesmo período, o aumento da área total de pastagens (nativas e cultivadas) no país foi de 15,3\% (IBGE, 1998).

Além da importância territorial das pastagens, ressalta-se que cerca de $90 \%$ da carne bovina produzida no país tem origem nos rebanhos mantidos exclusivamente em pastagens (Arruda, 1997), visto que não existe qualquer outro tipo de modalidade alimentar (capineiras, silagens e fenação) que seja mais competitiva do que a forragem colhida no campo pelo próprio animal (Nussio, 2000).

Dada a importância dessas áreas para a pecuária nacional, uma das mais otimistas estimativas a respeito da situação das pastagens é, no mínimo, surpreendente, pois 
destaca que ao redor de $80 \%$ das pastagens cultivadas nos Cerrados apresentam algum grau de degradação, sendo este apontado como um dos maiores problemas sociais, econômicos e ambientais vividos pela pecuária regional (Barcellos et al., 2001), além de ser considerado o maior problema relacionado com a sustentabilidade da produção animal em pastagens (Macedo, 2000). A razão principal para tal fato pode ser atribuída à concepção extrativista e tradicionalista (Da Silva \& Pedreira, 1997 a), não somente presente no Brasil (Fick \& Clark, 1998), de que pastos devem ser estabelecidos em áreas que apresentem sérias limitações à produção de culturas e, mesmo em tais condições, sejam capazes de produzir grandes quantidades de forragem de bom valor nutritivo a baixo custo (Da Silva, 1995).

O processo de degradação das pastagens pode ser atribuído tanto a problemas de ordem essencialmente técnica, caracterizados por erros no manejo das plantas forrageiras, quanto a associação entre a natureza dos solos tropicais - que apresentam sérias limitações em termos químicos e nutricionais à produção vegetal - e a ausência de práticas de correção e manutenção da fertilidade das áreas onde são cultivadas as pastagens, o que determina o agravamento dessa situação.

Uma análise criteriosa do problema revela ainda uma questão adicional menos aparente - devido à sua natureza - mas nem por isso menos importante, que é a notória falta de planejamento e organização presente nos sistemas de produção animal baseados no uso de pastagens. Por consequência, torna-se complicado definir estratégias de gerenciamento da propriedade, entre as quais aquelas envolvidas diretamente com o manejo do pastejo, bem como avaliar a rentabilidade da atividade sem que um objetivo pré-determinado de produtividade animal seja fixado. Na prática, tanto o planejamento como o desenvolvimento de sistemas pastoris, os quais exigem conhecimento e entendimento aprofundados dos processos que atuam na produção animal (Sbrissia, 2000), são substituídos por critérios empíricos e simplistas que, em última análise, apontam somente para ajustes no manejo do pastejo como solução da pecuária nacional. Como resultado, a pecuária brasileira é praticada, na grande maioria dos casos, de uma forma amadora, onde os resultados de produtividade e rentabilidade comprometem a longevidade da atividade e não possibilitam que a pecuária seja classificada como uma 
modalidade de exploração econômica da terra tão competitiva quanto cana-de-açúcar, milho e soja, por exemplo (De Faria et al., 1997; Da Silva \& Pedreira, 1997 a). Como consequência, a evolução da pecuária nacional no âmbito tecnológico (melhoria dos índices zootécnicos) e econômico (rentabilidade), fica limitada devido à falta de investimentos e a resistência a mudanças na filosofia de exploração por parte dos pecuaristas, motivadas por um processo contínuo de descapitalização, atualmente inerente à atividade, sendo esse o resultado mais marcante da ineficiência da pecuária nacional.

Especificamente, o que se observa na prática é que o manejo do pastejo é baseado em referenciais empíricos, apresentando um caráter pouco técnico e se resume, na maior parte das vezes, a um conjunto de informações a respeito de faixas amplas de alturas de entrada e de saída dos animais dos pastos (imprimindo uma conotação de que no país predominam sistemas baseados no uso de lotação intermitente ou rotacionada como estratégia de desfolha) ou, em outros casos, sendo definido por uma associação entre variações em taxa de lotação acompanhadas por diferentes ciclos de pastejo. Como consequência, os índices zootécnicos do rebanho nacional são ruins e caracterizam uma prova incontestável da inoperância da concepção extrativista da pecuária. Adicionalmente, advertem que mudanças radicais na filosofia de exploração animal baseada no uso de pastagens são urgentes no sentido da adoção de práticas de exploração racional, onde sistemas competitivos e eficientes de produção animal possam, enfim, ser planejados e desenvolvidos.

Um outro ponto passível de discordância atrelado ao modelo extrativista de produção animal está relacionado à falta de apreço dado ao contexto sistêmico do processo produtivo (Da Silva \& Sbrissia, 2000). A produtividade animal baseada no uso de pastagens é o resultado da interação entre os estágios de crescimento do pasto, de utilização da forragem produzida e a conversão da forragem produzida em produto animal (Hodgson, 1990). Cada um desses estágios de produção possui sua própria eficiência, a qual pode ser influenciada pelo manejo e que, em conjunto, determinam o nível de produção a ser atingido por um determinado sistema (Hodgson, 1990). Além disso, por definição, decisões de manejo que favoreçam a eficiência do processo de 
crescimento, resultam em redução na eficiência de utilização do pasto, bem como medidas que contemplem aumentos na eficiência de conversão da forragem em produto animal também atuam negativamente sobre a eficiência de utilização do pasto (Da Silva \& Sbrissia, 2000).

Como consequência dessa íntima interdependência e da natureza antagônica entre os estágios de produção, decisões de manejo que melhorem a eficiência em um deles tendem a reduzi-la em outro e vice-versa, ou seja, o manejo do pastejo tem a finalidade de gerenciar ineficiências parciais entre os estágios de produção, visando maximizar a produtividade do sistema. Tal peculiaridade limita a possibilidade de melhorias da produção animal através de mudanças simples e isoladas no manejo do sistema, mas também diminui o risco do sistema entrar em colapso como consequência de decisões erradas (Hodgson, 1990). Dessa forma, melhorias efetivas e duradouras em índices de produtividade animal em sistemas pastoris somente poderão ocorrer se alterações de caráter sistêmico em pontos chave do processo de produção forem realizadas, as quais devem ser consoantes com o objetivo da atividade (Da Silva \& Sbrissia, 2000).

Sob esta ótica, a reversão desse quadro terá início a partir de uma mudança de caráter filosófico (Corsi, 1986), onde num primeiro momento a eleição de objetivos específicos de produtividade animal é inquestionável. Num segundo momento, a partir do conhecimento dos limites ecofisiológicos de utilização das plantas forrageiras, ou seja, a determinação de amplitudes de condição do pasto dentro da qual a planta pode ser utilizada, se determinará a melhor estratégia de uso das pastagens, a qual será consequência direta de resultados de estudos de caráter multidisciplinar que contemplem aspectos de morfologia, fisiologia e ecologia das espécies forrageiras.

Estudos dessa natureza, embora ainda incipientes no Brasil e outras regiões tropicais do globo, têm mostrado que as plantas forrageiras tropicais apresentam respostas dentro de uma amplitude de condições de pasto sob a qual este pode ser utilizado convenientemente. Tal amplitude é elástica o suficiente para gerar combinações de alta eficiência de utilização do pasto associada a ganhos modestos de desempenho individual (exploração do mérito genético da planta forrageira), do mesmo 
modo que permite que taxas de lotação modestas sejam compensadas por elevado desempenho individual (exploração do mérito genético do animal). Tais resultados traduzem a plasticidade fenotípica das plantas forrageiras (Ernst et al., 1980; Briske, 1996), ou seja, a capacidade que as plantas têm de se adaptar à ação de agentes estressantes, e indica a possibilidade de uso de uma mesma espécie em cenários completamente diferentes (flexibilidade), submetida a regimes de desfolha distintos mas, acima de tudo, dentro de seus limites ecofisiológicos. Portanto, dentro de uma filosofia racional de exploração animal em sistemas pastoris, a escolha da estratégia de uso da planta forrageira deverá ser definida através dos objetivos da atividade.

$\mathrm{Na}$ atualidade, alguns dos mais relevantes aspectos relativos ao entendimento da ecofisiologia de plantas forrageiras em ecossistemas de pastagens e que merecem maior atenção da sociedade científica estão associados aos seguintes tópicos: os compostos de reserva, padrões de interceptação de luz e a arquitetura do dossel, o índice de área foliar, o perfilhamento controlado através do mecanismo de compensação tamanho/densidade populacional de perfilhos, o binômio intensidade-frequência de pastejo, a morfogênese de tecidos e a dinâmica do acúmulo de matéria seca, no que diz respeito ao universo das respostas da planta forrageira em relação à condição do pasto e, o comportamento ingestivo, os padrões de comportamento animal, o valor nutritivo da forragem ofertada e o desempenho individual do animal, no que se refere ao universo das respostas do animal em relação à condição do pasto.

Em suma, a produção animal em pastagens deverá se tornar um desafio maior na medida em que deixará de ser meramente uma colheita aleatória de produtos animais para se tornar uma atividade profissional, resultante do planejamento e controle da produção e utilização de forragem pelos animais.

O presente estudo teve por objetivo determinar o índice de área foliar, quantificar os teores e estoques de compostos de reserva (carboidratos não estruturais totais e frações nitrogenadas) e avaliar a taxa de acúmulo de forragem e a produção de pastos de Brachiaria brizantha (A. Rich.) Stapf submetidos a quatro intensidades de pastejo por bovinos de corte. 


\section{REVISÃO DE LITERATURA}

\subsection{Importância da manutenção de um estado de equilíbrio do pasto em estudos de ecofisiologia de pastagens}

Numa análise inédita sobre a contribuição da pesquisa científica nacional sobre a natureza dos trabalhos apresentados em Reuniões Anuais da Sociedade Brasileira de Zootecnia, em duas épocas distintas (1971-1975 e 1991-1995), De Faria et al. (1997) apontaram que as informações geradas para o desenvolvimento de sistemas de produção animal em sistemas pastoris são provenientes de trabalhos de pesquisa que, na sua grande maioria (84\%), foram realizados sem o uso de animais e, portanto, contribuem muito pouco com informações essenciais para a implementação de práticas de manejo. Por outro lado, nas situações onde os animais estavam presentes (16\%), as estratégias de manejo do pastejo foram definidas em termos de variáveis-resposta (normalmente taxas de lotação e ciclos de pastejo fixos) que não permitem um entendimento adequado e efetivo do que ocorre com as plantas forrageiras sob pastejo, uma vez que não consideram, em momento algum, características intrínsecas à planta forrageira, tampouco, a natureza dinâmica dos ecossistemas de pastagens (Da Silva \& Pedreira, 1997 b) não possibilitando, assim, a geração de informação alguma pertinente ao controle e manipulação das pastagens em termos de manejo do pastejo.

Hodgson (1985) relatou que o manejo do pastejo com base apenas em taxas de lotação e ciclos de pastejo predeterminados não permite a compreensão dos resultados integrados em termos de desempenho, tanto da planta forrageira como do animal, pois não podem ser considerados fatores determinantes dos processos de produção de forragem e desempenho do animal, sendo, portanto, incompletos no tocante ao 
direcionamento de bases que nortearão o manejo do pastejo. Além disso, o uso de taxas de lotação e ciclos de pastejo fixos com o objetivo de se eleger estratégias de manejo do pastejo, dada a rigidez desses parâmetros no que diz respeito ao entendimento e compreensão das respostas da planta forrageira e do animal em pastejo, traz dificuldades no sentido de se vislumbrar a extensão da flexibilidade da estratégia de manejo escolhida, a qual é fundamental para o planejamento da alimentação do rebanho em sistemas pastoris, bem como limita a identificação da contribuição potencial de componentes isolados dentro dos sistemas de produção.

O completo entendimento das respostas relativas ao desempenho da planta forrageira e do animal em sistemas pastoris somente pode ser efetivo quando os mecanismos intrínsecos a esses componentes do ecossistema pastoril e que determinam essas respostas forem totalmente compreendidos. Resultados de pesquisas realizadas em países como Nova Zelândia e Inglaterra com plantas forrageiras características desses locais (na sua maioria de fisiologia $\mathrm{C}_{3}$ ) nos últimos 20-30 anos (e.g. Bircham \& Hodgson, 1983), têm mostrado que os mecanismos que determinam as respostas das plantas forrageiras no tocante à produção de forragem são compreendidos quando a estrutura do pasto (altura, massa, índice de área foliar, etc.) é descrita de forma concomitante. Por outro lado, quando os mecanismos que determinam o desempenho individual do animal em pastejo, principalmente caracterizados por aspectos relacionados ao consumo, também passam a ser caracterizados em termos de variações na estrutura do pasto, o entendimento do assunto se torna "coincidentemente" claro. Nesse sentido, a estrutura do pasto parece ser o elo de ligação entre as respostas de desempenho observadas para esses dois universos intimamente relacionados, quais sejam, a planta forrageira e o animal. Portanto, a caracterização da estrutura do pasto permite o entendimento da grande maioria dos processos relativos à interface planta:animal para plantas de clima temperado (Hodgson \& Da Silva, 2002).

Entretanto, resultados recentes de trabalhos com plantas forrageiras tropicais têm evidenciado um grau de similaridade surpreendente em termos de respostas à desfolha dessas espécies relativamente àquelas de plantas forrageiras de clima temperado. É pertinente, no entanto, ressaltar que ainda que os processos, mecanismos e princípios 
que determinam a produção forrageira sejam idênticos, a exteriorização das respostas das plantas forrageiras assume valores distintos para cada espécie, visto que a plasticidade fenotípica, responsável pela amplitude das compensações entre esses processos e mecanismos é singular e específica (Hodgson \& Da Silva, 2002), justificando ainda mais a necessidade de se conhecer a planta forrageira (Da Silva \& Pedreira, 1997 b).

Assim, a importância da mensuração de variáveis estruturais do pasto em estudos relacionados ao manejo do pastejo fica caracterizada. De forma complementar, o reconhecimento e o entendimento da amplitude da flexibilidade das estratégias de manejo do pastejo somente podem ser alcançados a partir de estudos baseados no controle da condição/estado do pasto (Hodgson, 1985).

Além disso, ressalta-se que o estado do pasto também responde a variações em características do ambiente (solo e clima), características genéticas da planta, taxas de lotação, uso de insumos (fertilizantes e suplementos alimentares) e estratégias de manejo que determinam o uso desses componentes dentro do sistema, o que caracteriza a natureza dinâmica do estado do pasto (variações passageiras ao longo do tempo) e indica a necessidade de estudos multidisciplinares visando uma compreensão adequada de um assunto extremamente complexo.

É nesse sentido que Da Silva \& Pedreira (1997 b) caracterizaram com propriedade que os resultados da grande maioria dos trabalhos de pesquisa nacional não passam de uma mescla de efeitos dos tratamentos utilizados e uma combinação das interações possíveis entre todos os componentes do ecossistema pastoril, fazendo com que existam inconsistências e antagonismos quando se comparam vários experimentos que avaliaram aspectos semelhantes de uma mesma planta forrageira. Como consequência, conclusões efetivas sobre os assuntos estudados deixam de ser ou demoram demais a serem alcançadas. Dessa forma, um entendimento apropriado das respostas em termos do desempenho da planta forrageira e do animal sob regime de pastejo, e da sensibilidade desses componentes à interferência do manejo do pastejo, somente pode ser atingido em estudos baseados no controle e manipulação de características específicas do pasto num estado de equilíbrio (steady state) ou seguindo 
um padrão pré-especificado de variação (Hodgson, 1985). Evidencia-se, também, a necessidade de trabalhos de pesquisa que reconheçam o caráter dinâmico e altamente complexo de ecossistemas pastoris (Sbrissia, 2000). Esse reconhecimento permite que a pesquisa seja planejada de forma a estabelecer guias práticos de manejo, facilitando a difusão da informação gerada, que é fruto da avaliação detalhada de processos básicos que interagem entre si e determinam a dinâmica e a natureza das respostas de plantas forrageiras submetidas à desfolha. Essa característica confere consistência aos resultados obtidos e objetividade no planejamento e priorização de pesquisas futuras (Sbrissia, 2000), bem como, em última instância, o planejamento e desenvolvimento de sistemas de produção animal rentáveis e tecnicamente eficientes.

Nesse contexto, estudos que têm por objetivo definir as bases que direcionarão o manejo de espécies tropicais utilizadas como plantas forrageiras deveriam utilizar parâmetros como altura, massa de forragem, massa de folhas, interceptação luminosa, índice de área foliar, entre outros, de forma isolada ou em combinação, no sentido da caracterização e controle da estrutura do pasto ao longo do período experimental. Dessa maneira, as recomendações de manejo do pastejo passariam então a ser consistentes e permitiriam o planejamento e desenvolvimento de sistemas de produção animal baseados em relações de causa e efeito claras e objetivas.

\subsection{Espécie forrageira: Brachiaria brizantha cv. Marandu}

Numa extensa revisão taxonômica, Renvoize et al. (1996) apontaram que o gênero Brachiaria contém cerca de 97 espécies, com limites taxonômicos ainda mal definidos, distribuídas por toda a zona tropical do planeta. São encontradas espécies nativas no continente Americano (14), na Austrália (10) e no sudeste Asiático (6), sendo que aquelas originárias do continente africano são, indubitavelmente, as mais conhecidas e de maior importância para a pecuária tropical (67).

Segundo esses autores as braquiárias crescem dentro de uma grande faixa de variação de habitats (de várzeas e bosques sombreados até semidesertos) sendo que a 
maioria das espécies é encontrada nas savanas africanas. $\mathrm{O}$ interesse agronômico dado ao gênero está relacionado ao seu uso como plantas forrageiras em pastagens (Valle et al., 2000), embora sejam descritas como plantas daninhas agressivas e de controle custoso em áreas agrícolas.

Dados não oficiais mostram que as braquiárias, em especial Brachiaria decumbens Stapf, Brachiaria brizantha (A. Rich.) Stapf, Brachiaria humidicola (Rendle) Schweick e outras, em menor escala, ocupam cerca de $85 \%$ das pastagens na região dos Cerrados (42,5 milhões de hectares). Dos cerca de 50 a 55 milhões de hectares de pastagens cultivadas nessa região (Macedo, 1995; Sano et al., 1999), cerca de $21 \%$ são formados por Brachiaria brizantha cv. Marandu (Macedo, 2000), embora as estatísticas do setor de sementes mostrem que essa seja a espécie forrageira mais comercializada no país (Santos Filho, 1996).

A espécie braquiária brizanta, Brachiaria brizantha (A. Rich.) Stapf, é originária da África tropical (Nunes et al., 1985), embora se encontre difundida em Madagascar, Sri Lanka, Austrália, Suriname e Brasil. Dentre as brizantas, o cultivar Marandu é o mais encontrado no país, tendo sido trazido pela primeira vez da Zimbabwe Grasslands Research Station, localizada em Marandellas, Zimbábue, no ano de 1967 (Nunes et al., 1985; Alcântara, 1987; Keller-Grein et al., 1996). Foi cultivado por vários anos em Ibirarema, no Estado de São Paulo, de onde foi distribuído para várias regiões. Em 1976, foi cedido ao International Research Institute (IRI), em Matão, também no Estado de São Paulo e, em 1977 essa gramínea foi fornecida à EMBRAPA Gado de Corte, em Campo Grande, tendo sido incluída no processo de avaliação de plantas forrageiras da unidade. Em 1977/78 foi levada do Campo Experimental do IRI, em Suiamissu, no Estado do Mato Grosso, para a EMBRAPA Trópico Úmido, em Belém, no Estado do Pará. Em 1979 foi enviada para a EMBRAPA Cerrados, localizada em Planaltina, no Distrito Federal, com o intuito de ser avaliada sob as condições do Brasil Central. Em 1984 a Brachiaria brizantha cv. Marandu foi lançada pela EMBRAPA, sendo que o nome Marandu, dado ao cultivar, significa novidade no idioma Guarani, visto que se tratava de uma nova alternativa de forragem para a região dos Cerrados (Nunes et al., 1985). 
A brizanta é uma espécie cosmopolita em solos vulcânicos no continente africano, que geralmente apresentam boa fertilidade natural e localizam-se numa região com precipitação anual ao redor de $700 \mathrm{~mm}$ e cerca de 8 meses de seca no ano (Nunes et al., 1985; Valle et al., 2000).

De acordo com Nunes et al. (1985), é uma planta cespitosa, muito robusta, de 1,5 a 2,5 $\mathrm{m}$ de altura, com colmos iniciais prostrados, mas produzindo perfilhos predominantemente eretos. Rizomas muito curtos e encurvados. Colmos floríferos eretos, freqüentemente com perfilhamento nos nós superiores, o que leva à proliferação de inflorescências, especialmente sob regimes de corte ou pastejo. Bainhas pilosas com cílios nas margens, geralmente mais longas que os entre-nós, escondendo-os nos nós, o que confere a impressão de haver densa pilosidade nos colmos vegetativos. Lâminas foliares linear-lanceoladas, esparsamente pilosas na face ventral e glabras na face dorsal. Apresenta inflorescências de até $40 \mathrm{~cm}$ de comprimento, geralmente com 4 a 6 racemos, bastante equidistantes ao longo do eixo, medindo de 7 a $10 \mathrm{~cm}$ de comprimento, mas podendo alcançar $20 \mathrm{~cm}$ nas plantas muito vigorosas. A raque da inflorescência é estreita e tem forma de meia-lua. Espiguetas unisseriadas ao longo da raque, oblongas a elíptico-oblongas, com 5 a 5,5 mm de comprimento por 2 a 2,5 $\mathrm{mm}$ de largura, esparsamente pilosas no ápice.

Suas sementes são ligeiramente maiores que as das outras espécies do gênero Brachiaria, sendo que $1 \mathrm{~g}$ de sementes desse cultivar contém 145 sementes viáveis, enquanto que na decumbens, $1 \mathrm{~g}$ contém 184 sementes.

Os principais atributos positivos da brizanta podem ser resumidos em termos da alta resistência à cigarrinha-das-pastagens, alto potencial de resposta à aplicação de fertilizantes, capacidade de cobertura do solo, bom desempenho sob condições de sombra, bom valor nutritivo da forragem e alta produção de raízes e sementes. Por outro lado, apresenta baixo grau de adaptação a solos mal drenados, resistência moderada à seca e necessidade de solos medianamente férteis para persistência em longo prazo (Valle et al., 2000), sendo que a inclusão da exigência da brizanta em termos de fertilidade do solo não deveria ser enquadrada como um atributo negativo se uma análise dentro de uma filosofia de exploração racional de pastagens fosse elaborada, pois as 
plantas forrageiras devem ser reconhecidas como culturas tão ou mais exigentes quanto qualquer outra, possuindo requerimentos específicos que, isolada ou conjuntamente, determinam a produtividade e a persistência das pastagens (Da Silva, 1995).

A atual preferência pelo uso da brizanta (estatística do setor de sementes, Santos Filho, 1996) em comparação a decumbens é motivada basicamente pela susceptibilidade à cigarrinha-das-pastagens e pela ocorrência de fotossensibilização hepatógena atribuídos a esta última e que não foram até o momento detectadas em brizanta (Valle et al., 2000).

\subsection{Respostas das plantas forrageiras ao processo de desfolha}

As plantas fazem parte de um conjunto restrito de organismos que são capazes de produzir os compostos metabólicos responsáveis pela manutenção de seus ciclos, vegetativo e reprodutivo. Essa capacidade, no caso dos vegetais superiores, é conferida pelo processo de fotossíntese, pelo qual a absorção de luz através dos cloroplastos, localizados principalmente nas folhas, desencadeia um conjunto de reações físicas e bioquímicas que garantem o suprimento de energia necessário para a sobrevivência das plantas (Larcher, 1995).

Em sistemas pastoris, as plantas forrageiras estão sujeitas a desfolhas sucessivas, as quais apresentam frequência e intensidade dependentes do método de pastejo a que estão submetidas (Lemaire \& Chapman, 1996) e, dessa forma, necessitam produzir tecidos fotossintetizantes continuamente, visando sua persistência e longevidade dentro da pastagem.

As respostas das plantas à desfolha podem ser entendidas como um mecanismo de restabelecimento e manutenção dos padrões de crescimento, onde todos os recursos disponíveis devem ser usados de forma racional para se garantir, num primeiro momento, a formação de novos tecidos fotossintetizantes (folhas) visando restaurar um balanço positivo de energia e, por consequência, permitir o crescimento da planta (Lemaire \& Chapman, 1996). O processo de recuperação ao processo de desfolha 
apresenta duas fases distintas: (1) em curto prazo (dias), nota-se uma adaptação fisiológica devido a uma restrição no suprimento de carbono para o crescimento, resultante da remoção de tecidos fotossintetizantes (folhas); e (2) em longo prazo (semanas), quando os mecanismos de curto prazo são incapazes de restabelecer um balanço positivo de energia, é verificada uma readaptação relativa às atividades fisiológicas, incluindo ações em nível hormonal (Davies, 1995), resultando em modificações na expressão das características morfológicas da planta (Richards, 1993). Essas alterações morfológicas constituem uma importante parte da resistência das plantas ao pastejo, particularmente ligadas aos mecanismos de "preterimento" (Briske, 1996), os quais visam reduzir a probabilidade e a intensidade da desfolha de tecidos vegetais (Hodgkinson \& Williams, 1983; Lemaire \& Chapman, 1996).

Embora a importância dos tecidos fotossintetizantes (folhas) para a formação de novos tecidos e produção das culturas seja incontestável, Rodrigues \& Rodrigues (1987) e Rodrigues \& Reis (1995) relataram que durante muito tempo as orientações sobre o manejo do pastejo foram baseadas na utilização de compostos de reserva, principalmente nos teores de carboidratos não estruturais (CNE) acumulados em órgãos de reserva (raízes e base do colmo), pois se verificava uma redução nos teores desses compostos logo após a desfolha, a qual era atribuída à formação de novos tecidos (Davies, 1988). A maior justificativa para se atribuir à formação de novos tecidos aos carboidratos de reserva, segundo Volenec et al. (1996), se devia ao fato de que nenhum aspecto da fisiologia de plantas forrageiras havia sido estudado tão extensivamente quanto à função dos carboidratos de reserva em situações de estresse (desfolha, inverno) e persistência da planta no ambiente.

Essa hipótese, no entanto, foi contestada após a análise dos resultados relatados pelo trabalho clássico de Brougham (1956), que indicou uma relação inversa entre a velocidade de formação de novos tecidos e a intensidade de desfolha sofrida pela planta forrageira, destacando que a área foliar poderia ser mais relevante do que o teor de carboidratos não estruturais de reserva na recuperação da planta após a desfolha.

Adicionalmente, um terceiro fato merece ser considerado no que diz respeito à resposta de plantas forrageiras ao processo de desfolha. Embora existam resultados da 
década de 20 mostrando a importância dos compostos nitrogenados na recuperação da planta forrageira à desfolha (May, 1960; Avice et al., 1996 a; Volenec et al., 1996), apenas recentemente foram relatados resultados de pesquisas que investigaram a relevância desses compostos no referido processo (Ourry et al., 1988, 1993, 1994; Cyr \& Bewley, 1990; Kim et al., 1991; Hendershot \& Volenec, 1993; Avice et al., 1996 a, b, 1997 a, b; Core et al., 1996; Millard, 1996; Thornton \& Millard, 1997; Louahlia et al., 1999; Schnyder \& de Visser, 1999; Skinner et al., 1999 e Le Dily et al., 2001).

Atualmente, com o reconhecimento de que o êxito na recuperação das plantas forrageiras após a desfolha se deve tanto ao teor de compostos de reserva quanto à área foliar remanescente, é assumido que a importância de um em detrimento do outro se dará em situações específicas, revelando que esses mecanismos atuam de forma complementar e não competitiva. Nesse sentido, quando o regime de desfolha é definido por pastejos severos e pouco frequentes, as reservas assumem papel de destaque na garantia de formação de novos tecidos, visto que a área foliar remanescente possivelmente não seja capaz de permitir a renovação do dossel. Em contrapartida, se o regime de desfolha empregado é caracterizado por pastejos lenientes e frequentes, é provável que a área foliar remanescente seja suficiente para promover a recuperação da planta forrageira e, nessas condições, a importância dos compostos de reserva passa a ser secundária.

\subsection{1 Índice de área foliar (IAF): definição}

A produção de tecidos e, em última análise, a produtividade das culturas depende da fotossíntese, processo pelo qual a radiação solar, interceptada pelas folhas verdes, é transformada em energia química, que é utilizada para converter o dióxido de carbono $\left(\mathrm{CO}_{2}\right)$ do ar e a água $\left(\mathrm{H}_{2} \mathrm{O}\right)$ em açúcares simples. Cerca de $90 \%$ da massa seca do vegetal é constituída por compostos orgânicos derivados desses açúcares (Parsons \& Chapman, 2000). 
Considerando que o carbono é o principal elemento constituinte das plantas, cerca de 40 a 44\% na massa seca (Parsons \& Chapman, 2000), o acúmulo de biomassa vegetal é determinado pela fixação (assimilação) desse elemento em tecidos através do processo fotossintético (Lemaire \& Chapman, 1996). A taxa pela qual o carbono é assimilado, seja por uma planta ou pelo dossel de uma comunidade vegetal (pastagem, por exemplo), depende diretamente da quantidade de radiação fotossinteticamente ativa que é absorvida pelas folhas verdes presentes na planta ou no dossel, desde que outros fatores não sejam limitantes (Donald \& Black, 1958).

Devido à estreita relação entre a produção de biomassa vegetal e a interceptação luminosa, julgou-se necessária a eleição de parâmetros que as correlacionassem satisfatoriamente, seja de forma direta ou indireta, com o intuito de permitir a compreensão das relações funcionais existentes entre esses componentes do ecossistema. Foi sob esse contexto que se desenvolveu o conceito de índice de área foliar (IAF).

Tal conceito, inicialmente proposto por Watson (1947), está associado com a área foliar de uma face de folhas (Hodgson, 1990; Da Silva \& Pedreira, 1997 b) em relação à área de solo sombreada pela projeção da copa, quando o sol encontra-se a pino. No entanto, da forma como foi proposto por Watson (1947) e posteriormente abordado por Benicasa (1988), o IAF é um índice extremamente dinâmico, visto que a área foliar que ocupa uma determinada superfície de solo varia quase que instantaneamente ao longo do ciclo da planta, o que torna sua quantificação bastante complexa. Dessa forma, os valores de IAF encontrados na literatura referem-se a estimativas pontuais da área foliar de determinada cultura num determinado estádio de desenvolvimento.

Os primeiros pesquisadores que aplicaram o conceito de IAF relacionando-o ao processo de crescimento de plantas forrageiras e ao manejo do pastejo foram Brown \& Blaser (1968). Esses autores sugeriram o uso desse índice como uma ferramenta capaz de simplificar o entendimento das complexas relações entre a interceptação luminosa e os processos fisiológicos associados ao acúmulo de massa seca das plantas (Da Silva \& Pedreira, 1997 b).

Convencionalmente, quando 90 (Blaser et al., 1986) ou 95\% da luz incidente é interceptada pelo dossel, o IAF recebe uma denominação específica, qual seja, IAF 
“crítico" (Brown \& Blaser, 1968). Segundo esses autores quando praticamente toda a luz incidente é interceptada e a relação entre a fotossíntese bruta e a respiração é máxima (fotossíntese líquida máxima), obtém-se o IAF “ótimo". Nesse IAF a taxa de crescimento da cultura (TCC) é máxima, indicando que se obtém a maior massa seca acumulada por unidade de área e por unidade de tempo. Por fim, o IAF "teto" é obtido quando a taxa de produção de novas folhas (em unidades de massa) se iguala a taxa de morte das folhas basais ou inferiores, isto é, o máximo valor de IAF para uma determinada cultura sob uma determinada condição de manejo e ambiente é atingido (Brown \& Blaser, 1968).

Rotineiramente, pesquisadores e técnicos tentam encontrar os valores de IAF crítico, ótimo e teto dentro de curvas que relacionam crescimento de uma dada cultura em relação a unidades de tempo (dias, semanas). Ressalta-se que os conceitos de IAF crítico e ótimo não permitem que associações dessa natureza sejam realizadas de forma direta, principalmente pela forma como esses índices são gerados pela pesquisa, pois tanto o IAF crítico como o IAF ótimo somente podem ser encontrados em curvas que exprimem o comportamento do IAF da cultura em relação à interceptação de luz pelo dossel e fotossíntese líquida relativa, respectivamente. Já o IAF teto permite esse tipo de associação pois, por definição, é gerado através de uma relação entre o crescimento da cultura (acúmulo de massa) e o tempo. Assim, a forma mais indicada para se relacionar especificamente o IAF crítico e o ótimo dentro de curvas de crescimento da planta, normalmente descritas em relação a escalas temporais, seria a determinação dos mesmos em condições experimentais e, posteriormente, durante o processamento dos resultados, identificá-los na curva de crescimento da cultura (expressa em escala temporal).

\subsubsection{IAF e aspectos fisiológicos da produção de forragem}

Em termos fisiológicos, a produção de forragem é limitada pela quantidade de luz interceptada pelo dossel (dependente da área foliar e dos padrões de interceptação de luz), pela eficiência desse dossel na conversão da energia luminosa em massa seca 
(Verhagen et al., 1963) e pela presença de limitações quantitativas de água e nutrientes (Donald \& Black, 1958).

Sabendo-se que a luz (quantidade e qualidade) opera como fator decisivo no que diz respeito à competição entre vegetais (inter e intraespecífica) e a conseqüente ocupação do ambiente (Donald, 1963), pode-se afirmar que a produção de área foliar dentro de um determinado ecossistema ocorre até um valor máximo (IAF teto), que é definido pela disponibilidade de luz incidente (Briske, 1996). O IAF teto é o resultado de um equilíbrio inter e intraespecífico motivado pela competição por luz, de modo que fatores de ambiente, como água e a disponibilidade de nutrientes atuam somente sobre a velocidade com que a comunidade de plantas alcança esse equilíbrio determinado pela disponibilidade de luz (Sackville Hamilton et al., 1995).

De acordo com Brown (1984), sob condições favoráveis, o aumento da área foliar numa pastagem, seja após o estabelecimento ou após uma desfolha severa, apresenta normalmente um comportamento sigmóide. Como consequência desse aumento em área foliar, há um decréscimo na penetração de luz ao longo do perfil do dossel, visto que ocorre um progressivo aumento na interceptação de energia luminosa pelas plantas (colmos e folhas). A maior interceptação de luz observada em decorrência do aumento da área foliar resulta num acréscimo da taxa de fotossíntese bruta da comunidade vegetal, a qual é acompanhada por um aumento linear na taxa respiratória do dossel. O balanço entre essas taxas gera uma nova taxa, qual seja, a fotossíntese líquida (Parsons et al., 1988 b, c; Hodgson, 1990).

Além da compensação existente entre as taxas de fotossíntese bruta e respiração, um segundo tipo de equilíbrio aparece dentro do processo de produção de forragem, o balanço entre as taxas de fotossíntese líquida (crescimento) e senescência/morte de tecidos, do qual resulta a taxa de acúmulo de forragem (Parsons et al., 1988 b).

Embora tradicionalmente o comportamento das taxas e dos processos fisiológicos determinantes da produção forrageira seja caracterizado em função do tempo, pode-se traçar um raciocínio paralelo substituindo esse parâmetro pelo índice de área foliar do pasto, desde que não seja imposta às plantas nenhuma desfolha (crescimento livre). Nos primeiros estádios de crescimento ou rebrota da comunidade vegetal, observa-se uma 
reduzida área foliar caracterizando baixas taxas de fotossíntese líquida e acúmulo de forragem, sendo que durante esse período os processos de senescência e morte podem ser considerados desprezíveis (Parsons et al., 1988 b, c). À medida que o IAF aumenta, ocorrem incrementos nas taxas de fotossíntese líquida, senescência/morte e acúmulo de forragem, até um determinado valor de IAF, a partir do qual as taxas de respiração e senescência/morte passam a ser tão elevadas que o resultado em acúmulo de forragem é pequeno ou praticamente nulo. Sob tais condições, o sombreamento que se origina associado à excessiva quantidade de material morto pode comprometer de forma decisiva os processos responsáveis pela manutenção da perenidade da pastagem, principalmente no tocante ao perfilhamento (Parsons \& Chapman, 2000).

A mais importante implicação que pode ser observada como resultado das compensações entre esses processos fisiológicos dentro de uma amplitude de combinações entre o binômio intensidade-frequência de desfolha está associada à pequena variação passível de ser obtida na taxa de acúmulo de forragem dentro de uma amplitude considerável de valores de IAF (Parsons et al., 1988 c). Tal mecanismo limita que um aumento significativo na quantidade de forragem produzida seja obtido somente por alteração no regime de desfolha imposto ao pasto (Hodgson, 1990; Da Silva \& Pedreira, 1997 b).

\subsubsection{IAF em plantas forrageiras tropicais: resultados de pesquisa}

Resultados em termos de crescimento e produção forrageira e desempenho animal são intimamente relacionados à condição/estado do pasto (Hodgson, 1990). Por essa razão, pareceria lógico que as recomendações de manejo do pastejo fossem baseadas em parâmetros relacionados com os processos e mecanismos ecofisiológicos que determinam a produção de forragem. No entanto, para plantas tropicais essa realidade é diferente, com apenas um pequeno e bastante recente número de informações sendo disponível. 
Para plantas de clima temperado, já há algumas décadas, é estabelecido que a altura de uma dada massa de forragem é um parâmetro que se destaca com relação ao monitoramento da condição do pasto, dada sua capacidade de explicar as interações existentes entre as respostas relativas ao crescimento e a produção de forragem, bem como com aspectos que definem o consumo de forragem pelo animal (Hodgson \& Da Silva, 2002), o qual responde por grande parte do desempenho animal (Poppi et al., 1987).

Além da altura, outros parâmetros poderiam ser utilizados em estudos de ecofisiologia de plantas forrageiras. Assim, o monitoramento da condição do pasto poderia ser baseado na massa de folhas vivas e na a massa total de forragem entre outros parâmetros, os quais poderiam ser adotados de forma isolada ou em conjunto, tanto em situações de pesquisa como de campo. No entanto, nenhum desses apresenta a mesma praticidade de uso como a altura. Assim, parece ser compreensível a preferência pela altura como variável controle em experimentos dessa natureza.

Gomide et al. (1997), estudando Brachiaria decumbens dentro de uma amplitude de alturas variando entre 10 e $50 \mathrm{~cm}$, obtiveram uma variação no IAF de 3,3 a 8,4, respectivamente. A produção de massa seca total variou, para a mesma amplitude de alturas, de 4,4 a 15,2 $\mathrm{t} \mathrm{ha}^{-1}$, respectivamente. Da mesma forma que foi relatado para plantas forrageiras de clima temperado (Hodgson, 1990; Hodgson \& Da Silva, 2002), os resultados desse trabalho apontaram que a correlação entre a altura do pasto e o IAF foi muita elevada $\left(\mathrm{R}^{2}=0,92\right)$.

Em outro experimento, Grasseli et al. (2000), estudando a mesma planta forrageira mas dentro de uma amplitude menor de variações de altura do pasto $(10,15$, 20 e $25 \mathrm{~cm}$ ) mantido sob lotação contínua, obtiveram também alta correlação entre a altura do pasto e o IAF $\left(\mathrm{R}^{2}=0,96\right)$. A máxima interceptação luminosa foi obtida ao redor de $90,5 \%$ no pasto mantido a $25 \mathrm{~cm}$ de altura (na prática tal altura correspondeu a $22 \mathrm{~cm}$ ). A produção de biomassa do pasto, tanto total quanto de folhas, respondeu linearmente ao IAF e, consequentemente, à altura do pasto. Os autores concluíram que a altura de $25 \mathrm{~cm}$ foi a que maximizou a produção de forragem. Com base nos resultados do trabalho de Gomide et al. (1997), pode-se concluir que a amplitude de alturas 
utilizada por Grasseli et al. (2000) não foi suficiente para se detectar o limite superior de utilização da braquiária decumbens e, portanto, a conclusão do trabalho, no tocante à altura que maximizou a produção de forragem, deve ser vista com ressalva para a recomendação de estratégias de manejo do pastejo.

Trabalhando com Brachiaria brizantha cv. Marandu e Brachiaria humidicola, colhidas segundo intervalos entre cortes de 14, 28, 42 e 56 dias e uma única intensidade de desfolha para cada espécie (5 e $10 \mathrm{~cm}$ para humidícola e brizanta, respectivamente), Reis \& Azambuja (1996) relataram a existência de um incremento no IAF tanto da brizanta como da humidícola com intervalos entre cortes mais longos. Todavia, as respostas em termos de produção de massa seca total apresentaram comportamentos distintos, sendo crescente para humidícola e quadrática para brizanta. Os valores obtidos de IAF foram também distintos para essas espécies, variando entre 3,1 e 6,1 para a brizanta e 2,4 e 3,5 para a humidícola. A avaliação dos resultados dados permite concluir que devido à ocorrência de diferenças significativas observadas em termos de IAF e produção de forragem, as plantas provavelmente apresentam limites de utilização e amplitudes de plasticidade fenotípica distintas e, portanto, seria compreensível que fossem manejadas de forma diferente, muito embora pertençam à mesma espécie. Corsi et al. (1994) chegaram à conclusão semelhante quando estudaram aspectos relativos à morfogênese dessas mesmas espécies consideradas.

Especificamente, até o momento a amplitude de variações encontrada para o IAF respectivo às espécies forrageiras do gênero Brachiaria está entre 1 e 15 (Alcântara, 1987; Grasseli et al., 2000).

Fagundes (1999), estudando o gênero Cynodon (Tifton-85, Florakirk e Coastcross), avaliou vários aspectos morfofisiológicos sendo que, devido ao objetivo do presente trabalho, serão discutidos apenas os resultados relativos ao IAF e a interceptação luminosa. Pastos de Cynodon spp. foram manejados sob lotação contínua com taxa de lotação variável e submetidos a intensidades de pastejo (alturas de 5, 10, 15 e $20 \mathrm{~cm}$ ) por ovinos. De forma geral, os pastos mantidos mais altos $(15$ e $20 \mathrm{~cm})$ apresentaram os maiores valores de IAF. Os dados referentes à interceptação luminosa (IL) apontaram uma íntima relação entre IL e IAF, de modo que aumentos em IAF 
resultaram em aumentos em IL. Tomando-se como critério para monitoramento da condição do pasto a interceptação de $95 \%$ da luz incidente, os pastos de Tifton-85 estariam aptos para serem desfolhados a partir de $15 \mathrm{~cm}$ de altura. Já os pastos de Coastcross apresentaram os menores valores de IL, mesmo na altura de $20 \mathrm{~cm}$, valores esses muito inferiores aos $95 \%$ considerados ideais. Os pastos de Florakirk apresentaram um comportamento intermediário. O cultivar Tifton-85 interceptou consistentemente mais luz que os demais. Assim, poder-se-ia inferir que Tifton-85 apresentaria uma flexibilidade, em termos de amplitude de altura de colheita, maior que Florakirk e Coastcross, uma vez que interceptou $95 \%$ da luz incidente já a partir de $15 \mathrm{~cm}$ de altura, enquanto que Florakirk e Coastcross provavelmente atingiriam esse ponto em altura superior a $20 \mathrm{~cm}$.

Os resultados apresentados para plantas forrageiras tropicais, embora ainda incipientes, já indicam que quaisquer aproximações ou generalizações relativas ao manejo do pastejo para espécies pertencentes aos mesmos gêneros, fundamentadas na proximidade botânica das espécies, podem resultar em erros graves no manejo do pastejo, com reflexos na produtividade global do sistema, reforçando mais uma vez a necessidade de se conhecer a essência da biologia, fisiologia e morfologia de cada planta forrageira (Da Silva \& Pedreira, 1997 b).

\subsubsection{Compostos de reserva}

May (1960), em sua revisão sobre o uso de carboidratos por plantas forrageiras em pastagens após a desfolha, argumentou que a palavra "reservas" não seria a mais indicada quando o propósito fosse expressar o acúmulo de compostos orgânicos em tecidos vegetais, visto que o referido termo sugere uma provisão para o futuro e, na realidade, o que ocorre é um processo contínuo de acúmulo e utilização de compostos orgânicos em períodos de estresse (Bernatowicz, 1958). Assim, o vocábulo "acumulados" seria tecnicamente mais indicado. Todavia, devido ao uso consagrado do termo "reservas", o mesmo será utilizado no trabalho. 
Embora um conjunto de definições sobre reservas (Millard, 1996) seja encontrado na literatura, a definição apresentada por Sheard (1973) parece ser apropriada: reservas orgânicas são compostos constituídos por carbono e nitrogênio, elaborados e armazenados pela planta em órgãos permanentes, principalmente aqueles remanescentes à desfolha, usados como substrato nos processos de manutenção durante períodos de estresse e formação de novos tecidos durante a recuperação após desfolha. Apesar de antiga, essa definição se mostra mais completa do que aquela apresentada por Thornton et al. (2000), segundo a qual as reservas são caracterizadas quando há a remobilização de carbono e/ou nitrogênio, ou compostos constituídos por esses elementos, de um determinado tecido para sua utilização subseqüente em processos de crescimento e/ou manutenção em outro tecido.

As plantas fazem uso de dois processos para armazenar reservas, quais sejam, a formação propriamente dita de sítios de acúmulo de substâncias e a reciclagem interna de compostos orgânicos (Lemaire \& Millard, 1999). Segundo Thornton et al. (2000), o processo de formação de reservas envolve a deposição de carbono e/ou nitrogênio, ou compostos originados desses elementos, em organelas de armazenamento, tais como o vacúolo ou o amiloplasto. De forma alternativa, a formação de reservas nitrogenadas também pode ser feita através da deposição de esqueletos protéicos em órgãos de reserva, ou mesmo em sementes. Além disso, a produção de proteínas de reserva (VSP vegetative storage proteins) - grupo de proteínas sintetizadas preferencialmente durante a formação das reservas, utilizado na produção de novos tecidos e que se destaca por ser mais abundante do que outros tipos de proteínas em órgãos de armazenamento - seria um outro exemplo de formação desse tipo de reservas (Avice et al., 1996 b, 1997 a, b; Core et al., 1996; Volenec et al., 1996; Thornton, 2000; Le Dily, et al., 2001). A deposição de amido em raízes se constitui num exemplo de armazenamento de carbono através do processo de formação de reservas (Avice et al., 1997 b).

A alocação de compostos para a formação de reservas freqüentemente é feita por transporte ativo através de membranas, e ocorre quando a disponibilidade de carbono e/ou nitrogênio na planta excede os requerimentos para crescimento e manutenção de tecidos (Lemaire \& Millard, 1999). A reciclagem de compostos, também caracterizada 
como mecanismo de reserva, é mais dinâmica do que a formação de sítios de armazenamento e envolve, normalmente, pequenas quantidades de compostos que se encontram metabolicamente ativas (Thornton et al., 2000) e, portanto, prontas para serem utilizadas na gênese de tecidos. Segundo esses autores, a reciclagem de carbono e nitrogênio ocorre como uma consequência do desenvolvimento e renovação de tecidos e se caracteriza como uma forma dinâmica de reserva, pois disponibiliza compostos para a formação de novos tecidos em curto prazo. A reciclagem é a principal fonte de esqueletos nitrogenados usados em gramíneas no processo de recuperação de tecidos após a desfolha, de modo que a remobilização do nitrogênio freqüentemente envolve a senescência de tecidos (Ourry et al., 1988).

É provável, portanto, que o nitrogênio armazenado pelas gramíneas e mobilizado após a desfolha seja proveniente principalmente da reciclagem interna desse elemento, consequência da renovação de proteínas associada com o processo de senescência de tecidos (Thornton et al., 2000).

Com relação aos sítios de armazenamento, Sheard (1973) indicou que as plantas acumulam compostos de reserva em órgãos permanentes, remanescentes após a desfolha e/ou associados com mecanismos de reprodução vegetativa. Conseqüentemente, órgãos como raízes, rizomas, estolões ou base do colmo são utilizados para armazenar substâncias de reserva.

Um outro aspecto relevante em estudos relacionados ao comportamento de reservas e a recuperação de plantas forrageiras após desfolhas, mas que nem sempre é contemplado, diz respeito aos estoques de reservas orgânicas acumulados na planta forrageira, resultante do produto entre a concentração e a massa de órgãos de acúmulo (May, 1960). A mensuração dos estoques de reserva é fundamental, uma vez que as respostas da planta forrageira em relação à recuperação após a desfolha nem sempre são explicadas pelos teores dos compostos acumulados (Carvalho et al., 2001), mas pela quantidade de reservas disponíveis para a planta. Todavia, resultados de pesquisa que contemplem esse assunto são escassos, até mesmo para plantas forrageiras de clima temperado. 


\subsubsection{Carboidratos não estruturais (CNE)}

Os carboidratos se constituem na mais abundante classe de compostos encontrada em plantas, perfazendo entre 50 e $80 \%$ da biomassa total (\% MS) das espécies forrageiras (Moore \& Hatfield, 1994). Desempenham funções associadas a diversos processos metabólicos, transferência e armazenamento de energia e, quantitativamente, são os principais componentes da parede celular das plantas (função estrutural) (Moore \& Hatfield, 1994).

Por conveniência, os carboidratos encontrados em plantas podem ser classificados em dois grupos: (1) carboidratos estruturais, responsáveis pela delimitação celular (membranas) e sustentação das plantas, e (2) carboidratos não estruturais, que atuam em processos bioquímicos diversos, compreendendo a fração de carboidratos que é armazenada em estruturas de reserva (McIlroy, 1967).

Os carboidratos não estruturais normalmente acumulados em tecidos de reserva são os monossacarídeos, especificamente hexoses (glicose e frutose), oligossacarídeos (sacarose, maltose e, em menores quantidades, rafinose, estaquiose, manose, arabinose e xilose) e polissacarídeos (amido e frutosanas) (McIlroy, 1967; Smith, 1973). Os monossacarídeos, glicose e frutose, e os dissacarídeos, sacarose e maltose, são os carboidratos solúveis encontrados em maior quantidade nas plantas (Moore \& Hatfield, 1994).

Quanto aos tipos de carboidratos de reserva, as gramíneas originárias de regiões de clima temperado acumulam sacarose e frutosanas; já as gramíneas tropicais e as leguminosas armazenam sacarose e amido (May, 1960; Weinmann, 1961; Smith et al., 1964; Smith, 1969, 1973; Davies, 1988).

Embora Weinmann (1961) tenha apresentado os termos carboidratos "solúveis em água" e carboidratos "não estruturais" como sinônimos e, ainda hoje, ambos são rotineiramente utilizados em trabalhos científicos sem distinções, faz-se oportuno considerar que o amido é um polissacarídeo insolúvel em água, particularmente devido à presença da amilose (Smith et al., 1964; Smith, 1969, 1973), Portanto, em se tratando de 
gramíneas tropicais e leguminosas, seria apropriado fazer referência aos carboidratos de reserva como "carboidratos não estruturais".

A importância dos compostos de reserva para o processo de recuperação da planta forrageira após a desfolha tem sido um dos tópicos mais controversos da agronomia de pastagens (Vickery, 1981; Da Silva \& Pedreira, 1997 b) dada à natureza antagônica encontrada nos resultados de pesquisas, principalmente no tocante à importância dos carboidratos não estruturais. No entanto, não são raros os trabalhos que apontam alguma relação entre esses carboidratos e a velocidade de recuperação das plantas forrageiras após a desfolha (Volenec et al., 1996; Thornton et al., 2000). Contudo, uma análise crítica feita à luz dos conhecimentos atuais permite concluir que os antagonismos encontrados sobre a importância dos carboidratos não estruturais de reserva em relação à recuperação das plantas forrageiras após desfolha podem ser compreendidos através dos seguintes fatos: (1) devido ao desconhecimento dos limites de utilização da planta forrageira, a escolha da frequência e intensidade de desfolha é feita de forma empírica e variável entre experimentos que estudam aspectos semelhantes das mesmas plantas forrageiras; (2) existem confusões conceituais generalizadas em termos de qual fração de carboidratos, estaria de fato sendo determinada, ou seja, se os resultados descritos compreendem os carboidratos totais não estruturais ou somente a fração solúvel dos carboidratos e, por fim, (3) a pesquisa científica praticamente desconsiderou as ponderações da década de 20, que apontavam que a recuperação das plantas após a desfolha não era determinada diretamente pela utilização dos carboidratos não estruturais, mas pela quantidade e capacidade de imobilização de frações nitrogenadas depositadas em órgãos de reserva (May, 1960; Sheard, 1973; Richards, 1993; Ourry et al., 1994; Volenec et al., 1996; Avice et al., 1997 b; Thornton, 2000).

A amplitude de valores encontrada para os teores de carboidratos não estruturais em gramíneas forrageiras provenientes de clima temperado é de 60 a $180 \mathrm{~g} \mathrm{~kg}^{-1}$, ao passo que em gramíneas tropicais varia entre 10 e $140 \mathrm{~g} \mathrm{~kg}^{-1}$ (Gross, 1988; Moore \& Hatfield, 1994; Carvalho et al., 2001). Esses resultados comprovam a tendência generalizada para maiores teores de carboidratos não estruturais em gramíneas $\mathrm{C}_{3} \mathrm{em}$ comparação às $C_{4}$, conforme descrito por Humphreys (1991). 
Especificamente para o gênero Brachiaria, a literatura nacional dispõe de informações para braquiária decumbens, para a qual os teores presentes nas raízes ou parte aérea variaram indistintamente entre 10 e $80 \mathrm{~g} \mathrm{~kg}^{-1}$ (Reis et al., 1985; Gross, 1988; Soares Filho, 1991). No entanto, informações relativas a braquiária brizanta cv. Marandu não foram encontradas, à exceção do trabalho desenvolvido por Alexandrino (2000), no qual os resultados dos teores de carboidratos não estruturais foram calculados através de uma base normalmente não utilizada (massa fresca ao invés de massa seca), dificultando a comparação com os dados encontrados na literatura, razão pela qual não serão citados.

Os fatores que interferem no acúmulo de carboidratos não estruturais em órgãos de reserva já foram descritos em inúmeras oportunidades e, portanto, para maiores esclarecimentos sugere-se a leitura das revisões de May (1960), Weinmann (1961), Smith (1973), Gross (1988) e Soares Filho (1991).

Grande parte do conhecimento relativo ao comportamento dos teores de carboidratos não estruturais foi originada a partir de estudos onde a planta forrageira foi submetida a intensidades de desfolha e acompanhou-se a variação dos teores desses compostos acumulados nas raízes ou bases dos colmos, relativamente à velocidade de restabelecimento da área foliar ao longo do tempo (situações típicas de lotação intermitente) ou, ainda, doses de nutrientes, sobretudo o nitrogênio, foram usadas visando-se identificar alguma relação entre o nível crítico externo do nutriente e a velocidade de restabelecimento da planta após a desfolha (Reis et al., 1985; Gross, 1988; Soares Filho, 1991; Alexandrino, 2000).

Por definição, a natureza das respostas obtidas nesses trabalhos difere sensivelmente daquela proveniente de situações onde a planta é mantida num estado de equilíbrio ao longo do tempo (lotação contínua), particularmente se as variações nos teores de carboidratos forem caracterizadas em termos de comunidade vegetal (pastagem, por exemplo) ao invés de indivíduos (planta) isoladamente. A grande maioria desses trabalhos foi realizada em condições que se assemelham àquelas observadas em pastos manejados sob lotação intermitente, e mostra que logo após a desfolha há uma redução progressiva nos teores de carboidratos não estruturais de reserva (May, 1960; 
Weinmann, 1961; Reis et al., 1985; Blaser et al., 1986; Rodrigues \& Rodrigues, 1987; Gross, 1988; Soares Filho, 1991; Avice et al., 1996 b; Volenec et al., 1996; Thornton, 2000) e, somente quando a planta restabelece um balanço positivo de energia, esses compostos são novamente acumulados em órgãos de reserva (May, 1960; Weinmann, 1961; Reis et al., 1985; Blaser et al., 1986; Rodrigues \& Rodrigues, 1987; Gross, 1988; Soares Filho, 1991). Alterações nesse padrão de comportamento são normalmente verificadas quando a planta passa do estádio vegetativo para o reprodutivo (Reis et al., 1985), visto que apesar de existir área foliar suficiente para a produção de fotoassimilados, por ser a inflorescência um dreno muito forte de assimilados (Da Silva \& Pedreira, 1997 b), a planta pode lançar mão das reservas para assegurar o sucesso do processo de perpetuação da espécie.

A explicação mais apropriada para a referida distinção entre o comportamento dos teores de carboidratos em nível de comunidade de plantas ou de plantas individuais pode ser entendida considerando-se que as plantas mantidas numa condição de equilíbrio (lotação contínua) apresentam variações discretas nos teores de compostos de reserva dentro de uma mesma estação do ano, caso não ocorram intempéries climáticas, pois a condição média do pasto oscila pouco ao longo do tempo e, provavelmente, mudanças significativas nesses teores serão descritas apenas quando a comunidade de plantas passar do estádio vegetativo para reprodutivo (Reis et al., 1985). Todavia, se a abordagem for feita em nível de indivíduo isoladamente, considerando-se a existência de padrões de heterogeneidade na comunidade vegetal (Schwinning \& Parsons, 1999), resultados semelhantes àqueles obtidos em condições de desfolhas típicas de lotação intermitente poderão ser encontrados em pontos isolados do pasto, pois nesses pontos as plantas são permitidas crescer livre de desfolha durante um certo período de tempo, o qual é variável em virtude da densidade de lotação imposta ao dossel (Wade, 1991; Schwinning \& Parsons, 1999).

Com relação à função, May (1960) e Humphreys (1991) postularam que na maioria dos casos o estoque e as perdas das reservas lábeis de carboidratos são insuficientes para justificar grande parte da gênese de novos tecidos após a desfolha, embora esses sejam os compostos de reserva quantitativamente mais importantes. De 
acordo com Humphreys (1991), perfilhos jovens normalmente se tornam fotossinteticamente independentes num curto prazo de tempo após sua expansão, iniciando rapidamente a exportação de assimilados para outras partes da planta e passando de uma condição de "dreno" para a de "fonte". Nesse cenário, o autor argumenta que as reservas de carboidratos podem ser consideradas apenas como um mecanismo de tamponamento no sistema ao invés de uma reserva grande e utilizável.

Adicionalmente, May (1960), Vickery (1981), Ourry et al. (1988, 1994), Richards (1993), Avice et al. (1996 a), Volenec et al. (1996), Thornton \& Millard (1997), Thornton et al. (2000), Noquet et al. (2001) e Justes et al. (2002) apontaram que a redução nos teores de carboidratos não estruturais presentes em órgãos de reserva é devida principalmente à contínua respiração (síntese e manutenção) dos tecidos remanescentes após a desfolha ao invés da translocação para processos anabólicos, muito embora uma pequena parcela seja utilizada para a formação de tecidos (Avice et al., 1996 a). Portanto, em situações onde o binômio intensidade-frequência de desfolha não permite que o restabelecimento do crescimento seja efetuado pela área foliar remanescente à desfolha, a mobilização e translocação de compostos nitrogenados são responsáveis pela produção de novos tecidos (Avice et al., 1996 a; Lemaire \& Chapman, 1996; Volenec et al., 1996; Thornton et al., 2000; Le Dily et al., 2001; Noquet et al., 2001; Justes et al., 2002), até que as primeiras folhas passem da condição de dreno para fonte e, assim, permitam que um novo balanço positivo de energia seja alcançado dentro da planta.

Finalmente, o possível consenso sobre o verdadeiro papel das reservas orgânicas no processo de rebrota parece residir, em grande parte, no entendimento de aspectos de fisiologia e morfologia das plantas forrageiras (Da Silva \& Pedreira, 1997 b) como determinantes de padrões de partição de nutrientes durante o processo de crescimento das plantas e, nesse contexto, estudos baseados na utilização de isótopos passam a ser cada vez mais importantes para a compreensão efetiva do assunto (Avice et al., 1996 a). 


\subsubsection{Compostos nitrogenados}

Considerando-se que o carbono é o principal constituinte das plantas superiores sendo encontrado principalmente sob a forma de carboidratos, a taxa de acúmulo de biomassa vegetal em comunidades de plantas é, portanto, determinada pela taxa na qual esse elemento é incorporado aos tecidos (Lemaire \& Chapman, 1996). A taxa de acúmulo de carbono, por sua vez, é influenciada pelo conteúdo de nitrogênio presente na planta. Consequentemente, a interação e a dinâmica desses elementos estão intimamente ligadas aos processos metabólicos que resultam no crescimento da planta (Lemaire \& Chapman, 1996).

Enquanto compostos constituídos de formas reduzidas de carbono são os principais responsáveis pelo suprimento de energia da planta e de diversos outros organismos vivos, o nitrogênio deve ser visto como um elemento chave devido à sua participação em compostos como proteínas e ácidos nucléicos, os quais atuam diretamente na garantia da perpetuação da vida (Novoa \& Loomis, 1981).

Dentre as diversas classes de compostos químicos, o nitrogênio é encontrado somente em aminoácidos, proteínas, enzimas e ácidos nucléicos, os quais compreendem um grupo extenso de moléculas (Taiz \& Zeiger, 1998; Mengel \& Kirkby, 2001). Os aminoácidos são as unidades básicas que formam as proteínas. As proteínas ocorrem nos seres vivos, incluindo as plantas, como enzimas, acelerando a velocidade de inúmeras reações químicas em diversas vias metabólicas; no citoplasma e membranas, apresentando função estrutural e podem, ainda atuar como carregadores (carriers) em funções específicas de transporte intra e extracelular. Adicionalmente, os ácidos nucléicos têm a capacidade de codificar, armazenar e traduzir as informações genéticas em organismos vivos (Novoa \& Loomis, 1981; Elliot \& Elliot, 1997).

As plantas contêm cerca de 15 a $50 \mathrm{~g} \mathrm{~kg}^{-1}$ de nitrogênio, expresso em base de massa seca (Novoa \& Loomis, 1981; Taiz \& Zeiger, 1998; Whitehead, 2000; Mengel \& Kirkby, 2001), sendo que entre 80 e $90 \%$ desse teor corresponde somente ao nitrogênio presente na forma de proteínas (Novoa \& Loomis, 1981). 
Ainda que o nitrogênio seja indiscutivelmente um dos nutrientes mais estudados dentro das ciências agronômicas, consequência de sua grande influência na determinação da produção das culturas, não serão aqui apresentados comentários ou resultados dessa natureza, considerando-se que a abordagem segundo a qual o elemento será tratado difere daquela normalmente encontrada na literatura.

Reduções nos teores de compostos nitrogenados presentes em órgãos de reserva após a remoção da parte aérea são relatadas desde os primórdios do século XX (May, 1960; Avice et al., 1996 a; Volenec et al., 1996), embora os estudos relacionados ao comportamento das reservas em plantas forrageiras, conduzidos em diversas partes do mundo desde aquela época, praticamente ignoraram tais resultados e, consequentemente, até o início da década de 80, as informações sobre o assunto se resumiam somente ao comportamento de carboidratos não estruturais.

A partir da metade da década de 80 , começaram a ser publicados resultados de pesquisa, na sua extensa maioria com plantas forrageiras de clima temperado ou subtropical (dentre essas principalmente a alfafa (Medicago sativa L.)), que estimularam uma nova discussão sobre a importância dos carboidratos não estruturais de reserva na recuperação de plantas após a desfolha. Contrariamente ao que foi relatado durante pelo menos cinco décadas, e em conformidade com dados da década de 20 (May, 1960; Avice et al., 1996 a), tais trabalhos destacaram a importância de frações nitrogenadas na formação de tecidos após a desfolha, ressaltando que os carboidratos assumem importância secundária nesse processo. Os resultados de pesquisa mais relevantes são relatados em Ourry et al. (1988, 1993, 1994); Cyr \& Bewley (1990); Kim et al. (1991, 1993); Hendershot \& Volenec (1993); Avice et al. (1996 a, b, 1997 a, b); Core et al. (1996); Cunningham \& Volenec (1996); Millard (1996); Thornton \& Millard (1997); Louahlia et al. (1999); Schnyder \& de Visser (1999); Skinner et al. (1999); Le Dily et al. (2001); Noquet et al. (2001) e Justes et al. (2002).

Ainda que informações, mesmo que recentes e escassas, relativas ao estudo do comportamento dos teores de compostos nitrogenados em espécies forrageiras de clima temperado sejam encontradas na literatura internacional, com relação às plantas forrageiras tropicais, a quantidade de resultados existente é insuficiente ainda para que 
conclusões sejam tiradas a respeito do assunto, pois tais pesquisas foram desenvolvidas com um enfoque ligeiramente distinto daquele necessário para um melhor entendimento do problema em sistemas pastoris (Gross, 1988; Soares Filho, 1991; Alexandrino, 2000), além do que em nenhum caso foi observado o uso de animais.

À luz dos conhecimentos atuais, os quais avançaram surpreendentemente a partir do final da década de 80, principalmente fundamentados pelos trabalhos de Ourry et al. (1988, 1993, 1994) e Avice et al. (1996 a), sendo esse último o mais esclarecedor e completo a respeito da mobilização de carbono e nitrogênio até o momento, serão destacados os aspectos mais relevantes desse assunto que, ainda hoje, mesmo com um conjunto de resultados consistentes para plantas forrageiras oriundas de regiões de clima temperado ou sub-tropical, se mostra de alta complexidade, uma vez que envolve tópicos de fisiologia vegetal pouco explorados.

A principal informação proveniente desses trabalhos diz respeito às funções de compostos nitrogenados e carboidratos não estruturais em relação à recuperação da planta forrageira após ter sofrido desfolhas severas (IAF remanescente baixo). Nessa situação a formação de tecidos após a desfolha seria justificada principalmente pela mobilização de compostos nitrogenados de órgãos de reserva como raízes e base da coroa ou colmos em leguminosas e gramíneas, respectivamente, de modo que, os carboidratos não estruturais assumiriam importância secundária no referido processo. Os carboidratos são fundamentais durante o período em que o balanço de energia da planta é negativo (fotossíntese líquida menor que a respiração), visto que são responsáveis pela respiração dos órgãos remanescentes, além da respiração necessária à síntese dos novos tecidos (Avice et al., 1996 a; Volenec et al., 1996).

É importante ressaltar que a maior importância relativa dos compostos nitrogenados em comparação aos carboidratos não estruturais de reserva não deve ser confundida com uma maior importância do nitrogênio em relação ao carbono. Embora Avice et al. (1996 a) tenham mostrado que o teor de carbono das proteínas e aminoácidos presentes nas hastes e folhas da alfafa varia entre 18 e 32\%, respectivamente, Elliot \& Elliot (1997) apontaram que na composição média de proteínas esse teor normalmente varia entre 50 e $55 \%$, ao passo que o teor de nitrogênio 
oscila ente 12 e 19\%, indicando que mesmo nas frações nitrogenadas, o carbono é o principal constituinte.

Fica clara, portanto, a razão pela qual Avice et al. (1996 a) relataram que uma proporção significante (entre 14,5 e 58\%) da pequena quantidade de carbono (cerca de $5 \%$ ) mobilizada para a rebrota de tecidos foliares foi associada com a translocação de nitrogênio em alfafa. Nesse trabalho, a quantidade de carbono mobilizada e utilizada para respiração foi da ordem de $8 \%$ e $61 \%$, respectivamente, para parte aérea e raízes, o que demonstra que o custo de manutenção dos órgãos remanescentes após a desfolha é muito alto e, provavelmente, representa os maiores gastos de energia da planta durante essa fase de recuperação. Como consequência, foi observada uma maior mobilização do carbono armazenado em tecidos de reserva (74\%) em comparação com o nitrogênio (34\%) após 30 dias de experimento (Avice et al., 1996 a). Notou-se ainda que a translocação do nitrogênio se deu essencialmente durante os primeiros 14 dias, diferentemente do carbono, que foi utilizado ao longo dos 30 dias, embora não tenham sido apresentados dados indicando o momento do restabelecimento de um balanço positivo de energia na planta.

Com relação à caracterização dos compostos nitrogenados presentes em órgãos de reserva, os principais trabalhos relativos à descrição dessas frações relacionam exclusivamente as proteínas e aminoácidos (Ourry et al., 1988, 1993, 1994; Cyr \& Bewley, 1990; Kim et al., 1990; Hendershot \& Volenec, 1993; Avice et al., 1996 a, b, 1997 a; Volenec et al., 1996; Noquet et al., 2001), muito embora Silveira (1985) tenha apontado que as três principais frações de nitrogênio na planta seriam: $\mathrm{N}$ inorgânico $\left(\mathrm{NH}_{4}{ }^{+}\right.$e $\left.\mathrm{NO}_{3}{ }^{-}\right), \mathrm{N}$ em aminoácidos (aminoácidos, aminas e amidas) e $\mathrm{N}$ protéico. $\mathrm{A}$ justificativa para a mensuração exclusiva dos teores de proteínas e aminoácidos reside no fato que a planta prioriza o uso de esqueletos ou compostos orgânicos (aminoácidos e proteínas, respectivamente), previamente sintetizados para a formação de novos tecidos (Avice et al., 1996 a), ao invés de utilizar formas inorgânicas que necessitariam ser incorporadas a essas moléculas, uma vez que a planta busca minimizar gastos energéticos durante a fase de recuperação após desfolha (Millard, 1996). 
Dentre os compostos nitrogenados de reserva, os aminoácidos parecem ser os mais rápida e facilmente utilizados durante a gênese de tecidos, enquanto as proteínas se destacam como a mais importante fração em termos quantitativos (Ourry et al., 1988; Kim, et al., 1991; Hendershot \& Volenec, 1993; Volenec et al., 1996; Noquet et al., 2001; Justes et al., 2002). Normalmente, durante a recuperação das plantas após a desfolha, é observado um aumento marcante na atividade de enzimas proteolíticas (proteases) com concomitante redução nos teores de proteínas solúveis presentes em órgãos de reserva, resultando na produção de aminoácidos livres, que seriam translocados para as zonas meristemáticas e contribuiriam para a formação de tecidos foliares (Ourry et al., 1988; Hendershot \& Volenec, 1993; Volenec et al., 1996).

Na maior parte dos trabalhos, os resultados dos teores de aminoácidos e proteínas encontrados em órgãos de reserva são normalmente apresentados como teores relativos, de modo que os valores absolutos não são mostrados e, portanto, dificultam quaisquer comparações. Todavia, os resultados apresentados por Gross (1988) e Soares Filho (1991) revelaram teores de proteína bruta variando entre 3,8 e $77,1 \mathrm{~g} \mathrm{~kg}^{-1}$, com os teores de aminoácidos oscilando entre 66 e $2687 \mathrm{mg} \mathrm{kg}^{-1}$, ambos com braquiária decumbens.

Além do uso de isótopos, em alguns desses trabalhos foi inclusa a utilização da eletroforese visando a identificação de moléculas (aminoácidos ou proteínas) envolvidas na formação de tecidos após a desfolha. Hendershot \& Volenec (1993) notaram que três polipeptídios de 15,19 e $32 \mathrm{kD}$ (quilo Dalton) se destacaram quantitativamente (28\% do total de proteínas solúveis nas raízes), supostamente atuando como proteínas de reserva (VSP). A mobilização desses compostos durante os seis primeiros dias após a desfolha foi muito rápida e considerável em termos quantitativos e, assim que a planta apresentou balanço positivo de energia, foi observado o acúmulo desses polipeptídios.

A título de ilustração, cabe ressaltar que a maioria dos aminoácidos encontrados nos seres vivos é caracterizada como $\alpha$-aminoácidos (alfa aminoácidos) em função da posição ocupada pelo grupamento amina no esqueleto carbônico dos aminoácidos, ou seja, a ligação do grupo amino ocorre no carbono adjacente à carboxila $(\mathrm{COOH})$. São conhecidos mais de 200 aminoácidos, dos quais somente 20 são considerados protéicos, sendo que desses 19 são $\alpha$-aminoácidos (Elliot \& Elliot, 1997). 
A quase totalidade dos resultados aqui apresentados diz respeito a trabalhos desenvolvidos com plantas forrageiras caracterizadas por fisiologia $\mathrm{C}_{3}$ e realizados em condições de clima temperado. Fica clara, novamente, a enorme carência de informações com relação a mais um aspecto da ecofisiologia de plantas forrageiras tropicais, o qual especificamente parece fundamental para a manutenção da planta forrageira na pastagem, principalmente em situações de desfolha intensa ou mesmo total da parte aérea das plantas forrageiras.

\section{4 Área foliar e compostos de reserva: implicações no manejo do pastejo}

\subsubsection{Lotação contínua e lotação intermitente}

Antes de iniciar diretamente uma discussão relacionada ao manejo do pastejo propriamente dito, uma análise comparativa entre as duas principais estratégias de manejo do pastejo será apresentada.

Inicialmente, uma ressalva a respeito do termo lotação contínua merece ser feita, por motivos de erros conceituais frequentemente atrelados ao mesmo. Teoricamente, manejo sob lotação contínua implica na permanência dos animais em um mesmo pasto por um período longo de tempo (semanas ou meses), sendo que um controle da condição do pasto tão rigoroso quanto àquele dispensado em casos de lotação intermitente é exigido (Hodgson, 1990). Tecnicamente, o que se observa no país difere da verdadeira definição de método de lotação contínua, visto que os animais são colocados em grandes extensões de terra por longos períodos de tempo sem preocupação ou controle algum da estrutura do pasto.

Um dos mais polêmicos e controversos assuntos tratados pela pesquisa em termos de manejo de pastagens durante os últimos 60 anos está relacionado com as frequentes comparações entre os métodos de pastejo, lotação contínua e lotação intermitente, principalmente em termos da existência de vantagens relativas no tocante ao acúmulo de forragem e produtividade potencial entre os métodos (Ernst et al., 1980; 
Parsons et al., 1983 a, b; Parsons et al., 1988 a, b, c; Hodgson, 1985, 1990; Sbrissia \& Da Silva, 1999).

No entanto, graças aos resultados de pesquisas que os compararam através de algum atributo fisiológico ou estrutural do pasto (Parsons et al., 1983 a, b; 1988 a, b, c) e que permitem, portanto, um entendimento efetivo do assunto, observa-se que, em teoria, a utilização da lotação rotacionada pode permitir uma produtividade até 20 a 30\% superior à lotação contínua (Parsons et al, 1988 c; Hodgson, 1990). Todavia, essa vantagem é muito difícil de ser detectada na prática, principalmente porque é a utilização da forragem produzida pelo animal que determina, em última análise, a produtividade do sistema. Esse fato pode ser ratificado pelos dados apresentados por Ernst et al. (1980), que mostraram que os benefícios da lotação intermitente em comparação à lotação contínua sobre a produtividade do sistema foram de apenas 1,5\% e de $6 \%$ para explorações de gado leiteiro e de corte, respectivamente.

Sob um prisma científico, as diferenças entre os métodos de pastejo são mais imaginárias do que reais (Parsons \& Chapman, 2000) e, desde que o manejo do pastejo seja eficiente e coerente para um dado objetivo (monitoramento das condições de pasto preestabelecidas através de planejamento), a escolha do método de desfolha passa a ser uma questão de adequação do referido método ao sistema de produção, a qual é principalmente determinada pelo grau de flexibilidade exigida nas tomadas de decisão segundo o objetivo da atividade.

Dado que o método de pastejo empregado apresenta pouco impacto sobre a quantidade de forragem produzida em pastagens (Hodgson, 1990), é fundamental o conhecimento da existência de diferenças morfofisiológicas pontuais e marcantes em termos das respostas de plantas forrageiras aos métodos de desfolha (Parsons et al., 1988 b). Mais especificamente, o manejo sob lotação contínua é caracterizado por oscilações pequenas na condição do pasto ao longo da estação de crescimento (steady state), embora variações no comportamento das características estruturais sejam observadas. Em pastos mantidos sob lotação contínua, as flutuações no comportamento das taxas dos processos fisiológicos determinantes do acúmulo de forragem são tênues e dificilmente apresentam variações marcantes em termos de equilíbrio, razão pela qual o acúmulo de 
forragem é feito de forma contínua ao longo do ano. Além disso, as mudanças na condição do pasto são relativamente lentas.

Por outro lado, o manejo sob lotação intermitente se caracteriza pela presença de um período de rebrota, no qual a condição inicial de pós pastejo contrasta, em termos de fisiologia - teores e estoque de compostos de reserva, taxas de fotossíntese, respiração e senescência - morfologia e estrutura - índice de área foliar, interceptação luminosa, perfilhamento - com a condição de pré pastejo. As mudanças na estrutura do pasto são abruptas num curto espaço de tempo (rebrota), motivadas pela nova condição de ambiente, principalmente pela variação na disponibilidade de luz.

Nesse contexto, as amplitudes e o padrão de variação dos teores de compostos de reserva, índice de área foliar e acúmulo de forragem em pastos em estádio vegetativo mantidos sob lotação contínua, sofrem maior influência das condições de ambiente do que da natureza do processo de desfolha. Contrariamente, em pastos manejados sob lotação intermitente, as variações abruptas no comportamento das respostas dos parâmetros morfofisiológicos, particularmente durante a rebrota, são principalmente motivadas pela severidade do processo de desfolha, que permite um aumento repentino na disponibilidade de luz para as plantas.

Todavia, se as respostas das plantas à desfolha forem analisadas, independentemente do método de manejo do pastejo e através de uma base apropriada de comparação (atributo estrutural do pasto), isto é, se os valores pontuais de variáveiscontrole obtidos em lotação contínua forem confrontados com os valores médios das mesmas variáveis sob lotação intermitente, caracterizados pelo ponto médio entre as condições de pós e pré pastejo, o que se observa é que as respostas obtidas em lotação contínua descrevem o mesmo comportamento daquelas observadas em lotação intermitente. Portanto, análises comparativas entre lotação contínua e intermitente somente se tornam efetivas se realizadas nessas circunstâncias (Parsons et al., 1988 c). 


\subsubsection{Princípios de manejo do pastejo}

O manejo do pastejo é, na sua essência, o compromisso entre a necessidade de se manter área foliar para a fotossíntese e a de colher o tecido foliar produzido evitando-se perdas de forragem por senescência e morte de tecidos (Parsons, 1988). Contudo, a literatura mostra pouco consenso ao redor de qualquer regime de desfolha que seja ótimo para um dado sistema (Da Silva \& Pedreira, 1997 b), provavelmente devido às peculiaridades inerentes a cada unidade de produção associadas ao objetivo da atividade em termos de produção animal, de onde se conclui que os sistemas de produção são únicos, salvo raras exceções. Portanto, o planejamento do manejo do pastejo deve ser baseado no conhecimento das características da propriedade (solo, clima, infra-estrutura, mão-de-obra), na capacidade de investimento do empresário rural e no objetivo da atividade no que diz respeito à produção animal. Considerando a singularidade dos sistemas de produção animal baseados no uso de pastagens no Brasil, fica claro, portanto, que quaisquer definições relativas às estratégias de manejo do pastejo que não consideram as particularidades de cada sistema, isto é, sejam generalizadas, podem resultar em insucesso ou fracasso da atividade, fato que indica a natureza complexa do assunto.

Conforme foi comentado, historicamente as orientações sobre o manejo do pastejo estavam apoiadas na utilização de reservas orgânicas (carboidratos não estruturais), acumuladas nas raízes e base dos colmos, para a produção de novos tecidos, pois se observava uma redução nos teores dessas reservas após a desfolha (Rodrigues \& Reis, 1995).

Recentemente, graças à compreensão de que o êxito no processo de formação de tecidos após a desfolha se deve tanto ao uso de reservas orgânicas (compostos nitrogenados e carboidratos não estruturais) armazenadas em órgãos de reserva, quanto à área foliar remanescente, pode-se concluir que ao invés de se apresentarem como mecanismos competitivos, visando o restabelecimento dos padrões de crescimento da planta, ambos atuam de forma complementar, de modo que a relevância de um em 
detrimento do outro se dará em situações específicas, destacando uma vez mais a complexidade do assunto (Corsi et al., 1994).

Admitindo-se que a importância da mobilização de reservas orgânicas se dará em situações onde a área foliar remanescente for incapaz de garantir a formação de tecidos, o que ocorrerá de forma isolada em sistemas pastoris baseados em conceitos racionais (renovação de tecidos após o inverno e queimadas), visto que é coerente que o manejo do pastejo seja baseado exclusivamente na manutenção da área foliar, serão tecidos alguns comentários a esse respeito.

Inicialmente, existem duas características básicas que devem ser consideradas para que o entendimento do efeito do manejo do pastejo sobre a produção de forragem seja efetivo. Primeiramente, uma vez que há um constante surgimento e morte de tecidos numa pastagem em crescimento, todo o material não colhido acaba morrendo (senescência) e é perdido (Parsons et al., 1983 b). Em segundo, normalmente o que é colhido através do pastejo são predominantemente as folhas, as quais se constituem no principal órgão fotossintetizante da planta (Parsons \& Chapman, 2000). Por esse motivo, a interação entre a frequência e a intensidade da desfolha afeta o grau de remoção desses tecidos, com consequências sobre o crescimento subseqüente.

O manejo deve, então, atingir um compromisso entre a conflitante demanda das plantas, que necessitam de área foliar para a fotossíntese, e a necessidade de remover folhas para alimentar os animais (Parsons et al., 1983 b; Da Silva \& Pedreira, 1997 b). Considerando-se que os princípios fisiológicos que determinam a produção de forragem em pastos mantidos sob lotação contínua e intermitente são, por definição, os mesmos, e desde que as comparações entre esses métodos sejam apresentadas em relação a uma mesma base comparativa (condição média do pasto ao longo do tempo, por exemplo), a associação entre os mesmos é válida (Parsons et al., 1988 c).

Parsons et al. (1983 a) apontaram que diferentes padrões de desfolha podem afetar a fotossíntese por alterar a proporção de folhas de diferentes idades no pasto. Consequentemente, em pastagens mantidas sob lotação contínua e com baixo IAF, as folhas novas são produzidas sob alta luminosidade, sem serem sombreadas pelas folhas mais velhas e, dessa forma, desenvolvem alta capacidade fotossintética (corresponde ao 
início do período de rebrota em situações de lotação intermitente, ou seja, pós-pastejo). Quando a pressão de pastejo é ainda mais alta, muitas folhas são removidas ainda jovens ou mesmo ainda na fase de expansão, de modo que uma proporção importante das folhas fotossinteticamente mais eficientes é removida e a fotossíntese do dossel diminui progressivamente com o aumento da intensidade de desfolha (Parsons et al., 1983 a). Por essa razão, apesar do alto potencial fotossintético das folhas e da adaptação morfológica (plasticidade fenotípica) das plantas mantidas em baixo IAF (maior número de perfilhos de menor massa) sob lotação contínua, isto não é suficiente para compensar a redução na área foliar, resultando em baixa produtividade do pasto (Parsons et al., 1983 a).

Diferentemente, em pastos manejados sob lotação contínua com IAF alto (corresponde ao final do período de rebrota em pastos mantidos sob lotação intermitente, isto é, pré-pastejo), as taxas dos processos fisiológicos determinantes da produção de forragem são elevadas, ou seja, as taxas de fotossíntese bruta e líquida são sensivelmente maiores do que aquelas reportadas em pastos mantidos sob baixo IAF (início do período de rebrota). As taxas de respiração, senescência e morte de tecidos também são mais elevadas, de tal sorte que um conjunto de compensações entre esses processos é estabelecido. Como consequência, a quantidade de forragem acumulada em pastos mantidos sob baixos valores de IAF não deveria ser muito distinta daquela obtida em pastos manejados em valores altos de IAF (Ernst et al., 1980; Parsons et al., 1983 b). No entanto, Parsons et al. $(1988$ c) relataram, com muita propriedade, que independentemente do método de pastejo (lotação contínua ou intermitente), a máxima taxa média de acúmulo de forragem e, consequentemente, a máxima produtividade potencial do pasto, é alcançada em valores mais baixos de IAF médio do pasto, visto que em ambos os métodos, essa condição determina o melhor balanço entre os processos determinantes da produção de forragem.

Dessa maneira, altas taxas fotossintéticas e altas taxas de produção bruta de tecidos, características de pastos mantidos sob alto IAF não podem estar associadas com alta produção colhível e, portanto, alta eficiência de utilização do pasto, peculiares de pastos mantidos sob baixos valores de IAF (Parsons et al., 1988 c; Hodgson, 1990). Assim, a maior implicação desses conceitos é que o manejo do pastejo tem seu maior 
efeito na eficiência de utilização da forragem colhida pelo animal em pastejo e, desde que manejo seja embasado por conhecimentos de ecofisiologia de pastagens e respeite os limites de utilização da planta forrageira, pouco afeta a quantidade de forragem acumulada no pasto (Grant et al., 1988; Parsons et al., 1988 c). 


\section{MATERIAL E MÉTODOS}

\subsection{Material}

\subsubsection{Espécie vegetal}

Segundo Mitidieiri (1983) e Nunes et al. (1985), a espécie estudada classifica-se, de acordo com o "Sistema Engler", como divisão Angiospermae; classe Monocotyledoneae; ordem Graminales; família Gramineae; subfamília Panicoideae; tribo Paniceae; gênero Brachiaria e espécie Brachiaria brizantha (A. Rich) Stapf. cv. Marandu.

\subsubsection{Local do experimento}

O experimento foi conduzido na Unidade Experimental de Plantas Forrageiras (UEPF), em área do Departamento de Produção Animal da Escola Superior de Agricultura “Luiz de Queiroz", pertencente à Universidade de São Paulo, município de Piracicaba, Estado de São Paulo. As coordenadas geográficas aproximadas do local do experimento são $22^{\circ} 42^{\prime}$ de latitude sul e $47^{\circ} 37^{\prime}$ de longitude oeste, sendo a altitude de cerca de 550 metros. O relevo da área experimental classifica-se entre suave e moderadamente ondulado. O período experimental foi de 27 de agosto de 2001 a 28 de fevereiro de 2002, com duração de 186 dias. 


\subsubsection{Solo da área experimental}

O experimento foi instalado num solo classificado como Nitossolo Vermelho eutroférrico, com horizonte A moderado e a textura variando de argilosa a muito argilosa (EMBRAPA, 1999). Na Tabela 1 encontram-se os resultados da análise química de terra de cada unidade experimental (parcela). Devido aos valores satisfatórios de $\mathrm{pH}$ e dos teores de nutrientes em relação às exigências da espécie em estudo (Raij et al., 1996), não foi realizada prática alguma de correção do solo no momento do estabelecimento da planta forrageira.

Tabela 1. Resultados da análise química de terra da área experimental.

\begin{tabular}{|c|c|c|c|c|c|c|c|c|c|c|}
\hline Parcela* & $\begin{array}{c}\mathrm{pH} \\
\mathrm{CaCl}_{2}\end{array}$ & $\begin{array}{l}\text { M.O. } \\
\mathrm{g} \mathrm{dm}^{-3}\end{array}$ & $\begin{array}{c}\mathrm{P} \\
\mathrm{mg} \mathrm{dm}\end{array}$ & \multicolumn{6}{|c|}{$\mathrm{mmol}_{\mathrm{c}} \mathrm{dm}^{-3}$} & $\begin{array}{l}\mathrm{V} \\
\%\end{array}$ \\
\hline \multicolumn{11}{|c|}{ Bloco 1} \\
\hline I 10 & 5,6 & 44 & 64 & 73 & 22 & 11,4 & 29 & 106,4 & 135,4 & 79 \\
\hline I 20 & 5,9 & 48 & 52 & 60 & 19 & 7,1 & 28 & 86,1 & 114,1 & 75 \\
\hline I 30 & 5,9 & 44 & 59 & 69 & 23 & 6,8 & 28 & 98,8 & 126,8 & 78 \\
\hline I 40 & 6,0 & 44 & 47 & 74 & 26 & 6,2 & 24 & 106,2 & 130,2 & 82 \\
\hline \multicolumn{11}{|c|}{ Bloco 2} \\
\hline II 10 & 5,7 & 44 & 58 & 56 & 19 & 6,5 & 33 & 81,5 & 114,5 & 71 \\
\hline II 20 & 5,8 & 46 & 51 & 59 & 18 & 7,8 & 33 & 84,8 & 117,8 & 72 \\
\hline II 30 & 5,6 & 40 & 51 & 59 & 19 & 8,6 & 31 & 86,6 & 117,6 & 74 \\
\hline II 40 & 5,7 & 40 & 58 & 49 & 18 & 7,4 & 29 & 74,4 & 103,4 & 72 \\
\hline \multicolumn{11}{|c|}{ Bloco 3} \\
\hline III 10 & 5,6 & 41 & 61 & 88 & 20 & 5,9 & 36 & 113,9 & 149,9 & 76 \\
\hline III 20 & 5,5 & 43 & 56 & 72 & 16 & 5,6 & 34 & 93,6 & 127,6 & 73 \\
\hline III 30 & 5,5 & 40 & 80 & 63 & 19 & 7,4 & 36 & 89,4 & 125,4 & 71 \\
\hline III 40 & 5,5 & 41 & 82 & 81 & 20 & 5,7 & 36 & 106,7 & 142,7 & 75 \\
\hline \multicolumn{11}{|c|}{ Bloco 4} \\
\hline IV 10 & 5,2 & 35 & 89 & 91 & 14 & 5,9 & 45 & 110,9 & 155,9 & 71 \\
\hline IV 20 & 5,2 & 37 & 84 & 111 & 17 & 5,2 & 47 & 133,2 & 180,2 & 74 \\
\hline IV 30 & 5,0 & 38 & 80 & 86 & 11 & 2,5 & 55 & 99,5 & 154,5 & 64 \\
\hline IV 40 & 5,2 & 38 & 96 & 93 & 15 & 3,5 & 50 & 111,5 & 161,5 & 69 \\
\hline
\end{tabular}

* Algarismos romanos (I a IV) significam o número do bloco (1 a 4) e algarismos arábicos $(10,20,30$ e 40$)$ significam as alturas do pasto $(\mathrm{cm})$. 


\subsubsection{Clima}

Segundo o sistema Köppen, o clima da região de Piracicaba é classificado como Cwa, ou seja, mesotérmico úmido subtropical de inverno seco, onde a temperatura média do mês mais frio é inferior a $18^{\circ} \mathrm{C}$ e a do mês mais quente ultrapassa $22^{\circ} \mathrm{C}$ (Brasil, 1960). Os dados climáticos referentes ao período experimental foram coletados no posto meteorológico do Departamento de Ciências Exatas da USP/ESALQ, localizado a aproximadamente $500 \mathrm{~m}$ da área experimental (Tabela 2 e Figuras 1, 2 e 3). A Tabela 3 e a Figura 4 mostram os resultados do balanço hídrico decendial entre os meses de setembro de 2001 e fevereiro de 2002. Através da análise do balanço hídrico foi possível verificar os períodos de deficiência hídrica, especialmente em setembro e entre o final do mês de outubro e o início de novembro. Os valores apresentados foram determinados considerando-se uma CAD (capacidade de armazenamento de água) de 50 $\mathrm{mm}$.

Tabela 2. Radiação solar global, insolação diária, precipitação total e temperaturas médias mensais do ar (mínima, média e máxima) durante o período experimental.

\begin{tabular}{lcccccc}
\hline \multirow{2}{*}{ Mês } & Radiação & Insolação & Precipitação & \multicolumn{3}{c}{ Temperatura $\left({ }^{\circ} \mathrm{C}\right)$} \\
\cline { 5 - 7 } & $\begin{array}{c}\text { Global } \\
\text { cal cm } \text { dia }^{-1}\end{array}$ & $\begin{array}{c}\text { Diária } \\
\text { horas dia }^{-1}\end{array}$ & $\begin{array}{c}\text { Total } \\
\text { mm }\end{array}$ & $\begin{array}{c}\text { Mínima } \\
\text { média }\end{array}$ & Média & Máxima \\
média \\
\hline Setembro/2001 & 425 & 7,2 & 48,4 & 14,7 & 21,4 & 28,1 \\
Média (84 anos) & 379 & 6,8 & 63,7 & 13,4 & 20,7 & 28,1 \\
Outubro/2001 & 496 & 7,9 & 173,3 & 16,1 & 22,8 & 29,5 \\
Média (84 anos) & 438 & 6,9 & 111,1 & 15,6 & 22,3 & 28,9 \\
Novembro/2001 & 466 & 6,7 & 152,4 & 18,7 & 24,7 & 30,7 \\
Média (84 anos) & 474 & 7,4 & 130,6 & 16,7 & 23,1 & 29,6 \\
Dezembro/2001 & 427 & 5,4 & 204,2 & 18,7 & 24,0 & 29,2 \\
Média (84 anos) & 450 & 6,6 & 201,0 & 18,2 & 23,9 & 29,6 \\
Janeiro/2002 & 410 & 4,7 & 320,2 & 19,3 & 24,5 & 29,8 \\
Média (84 anos) & 447 & 6,3 & 225,6 & 19,0 & 24,6 & 30,0 \\
Fevereiro/2002 & 404 & 5,1 & 187,9 & 18,8 & 23,9 & 29,0 \\
Média (84 anos) & 438 & 6,5 & 184,1 & 19,0 & 24,6 & 30,2 \\
\hline
\end{tabular}

Fonte: ESALQ, Departamento de Ciências Exatas (2002). 


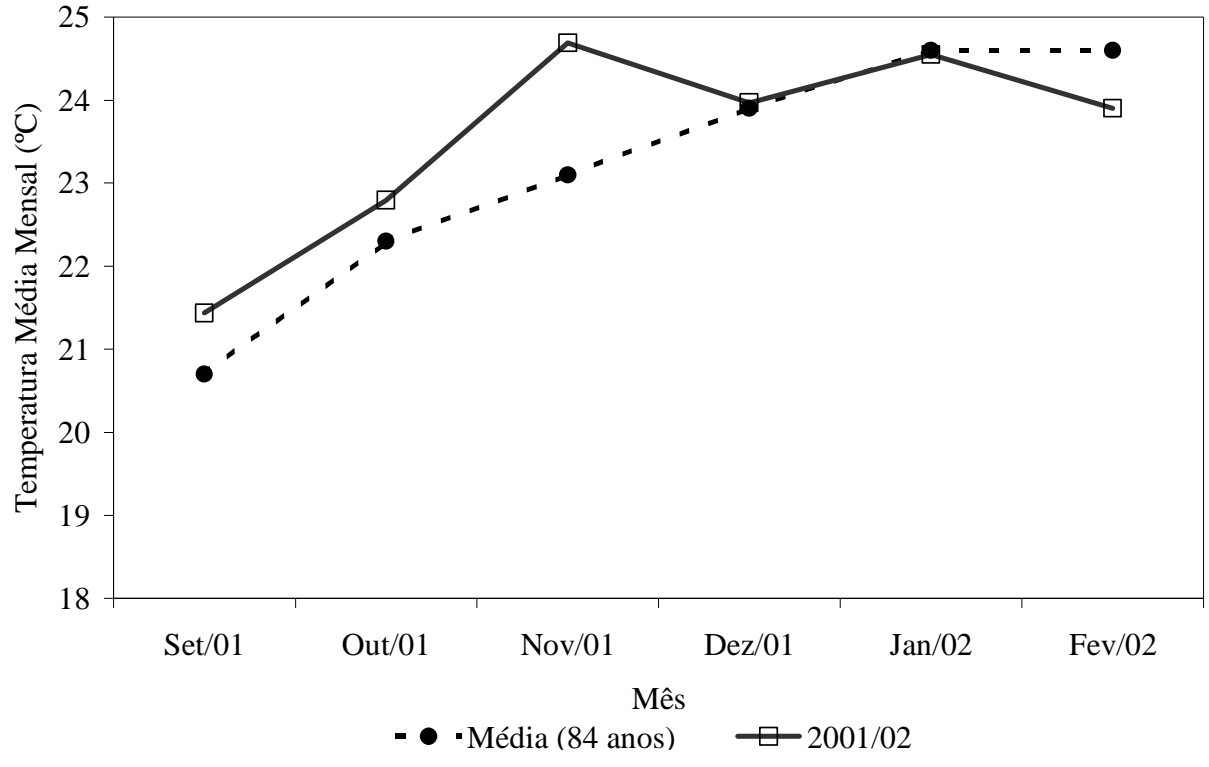

Figura 1 - Distribuição da temperatura média durante o período experimental comparada com a média dos últimos 84 anos (1917-2001).

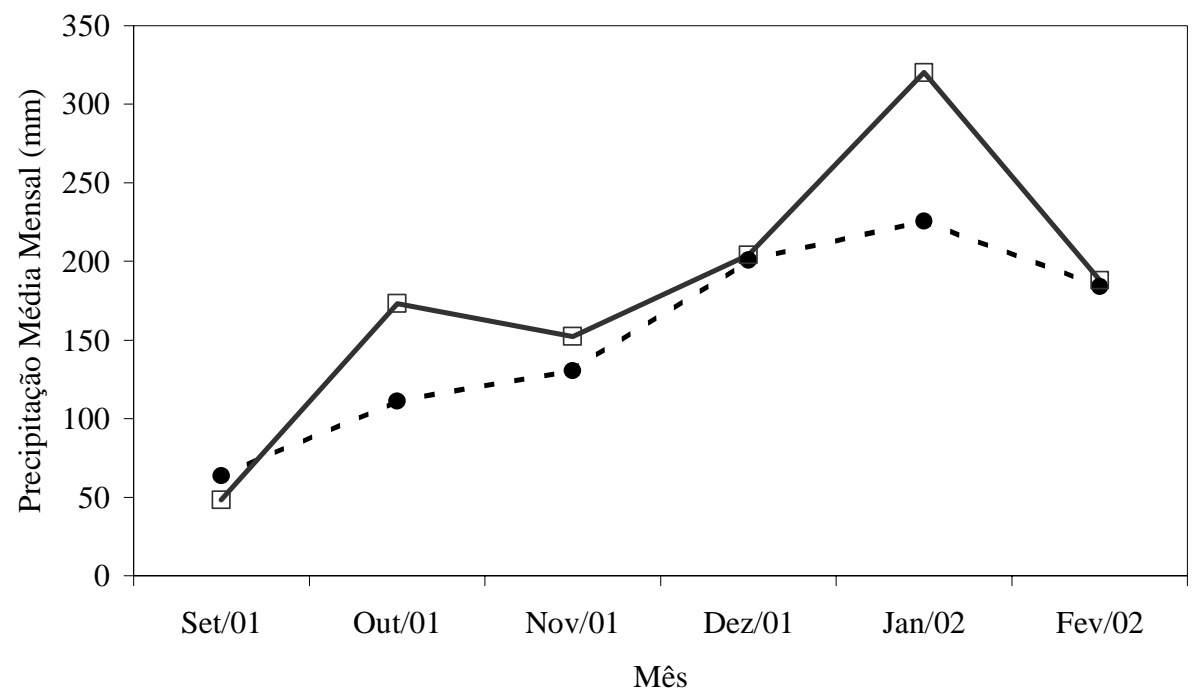

- - Média (84 anos) $\square$ 2001/02

Figura 2 - Distribuição da precipitação durante o período experimental comparada com a média dos últimos 84 anos (1917-2001). 


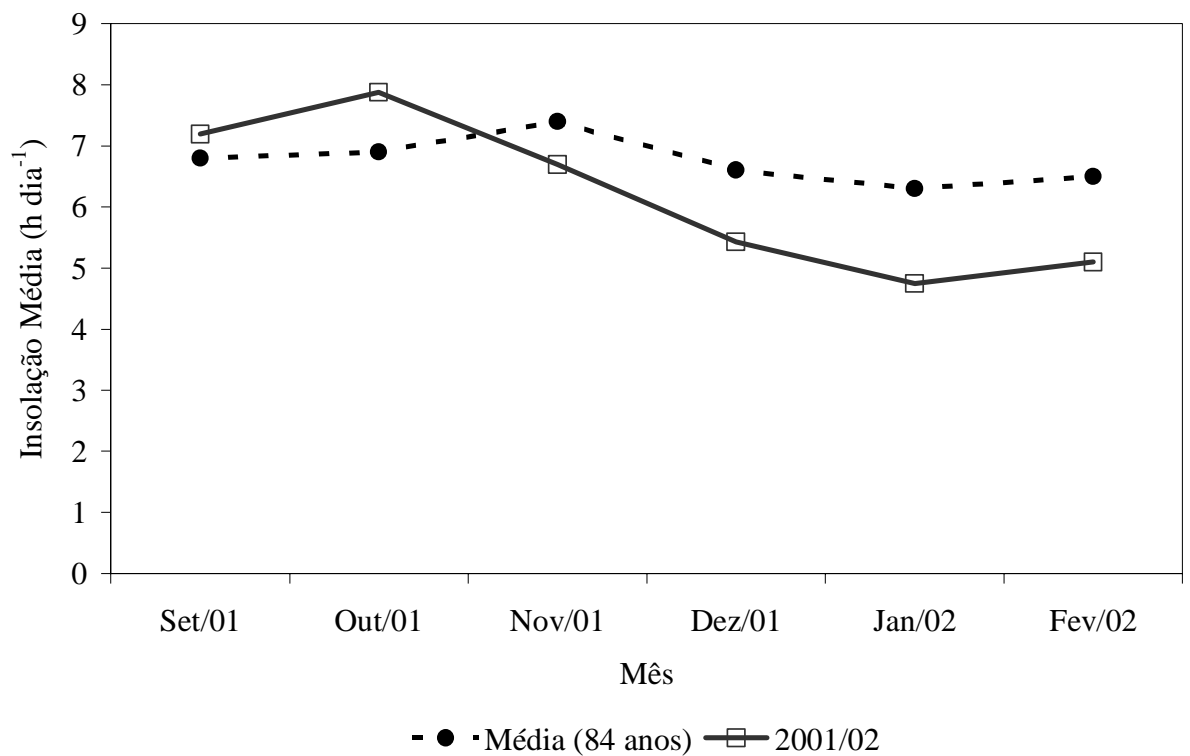

Figura 3 - Distribuição da insolação média durante o período experimental comparada com a média dos últimos 84 anos (1917-2001).

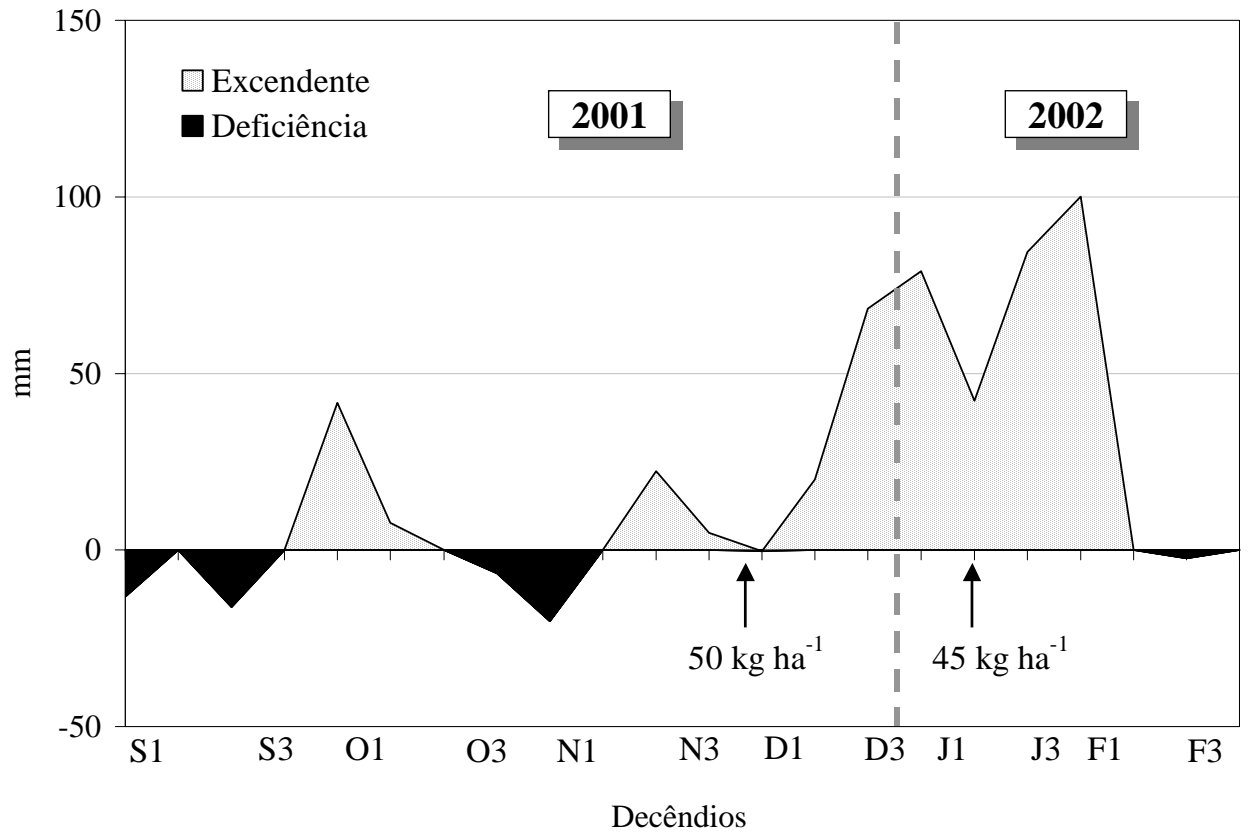

Figura 4 - Extrato do balanço hídrico dos decêndios mensais do período de setembro de 2001 a fevereiro de $2002(\mathrm{CAD}=50 \mathrm{~mm})$ e épocas de adubação nitrogenada. 
Tabela 3. Resultados do balanço hídrico mensal do primeiro decêndio de setembro/2001 ao terceiro decêndio de fevereiro/2002.

\begin{tabular}{ccccccc}
\hline Decêndio & & $\begin{array}{c}\text { Número de } \\
\text { Dias }\end{array}$ & $\begin{array}{c}\text { Temperatura } \\
{ }^{\circ} \mathrm{C}\end{array}$ & Precipitação & $\begin{array}{c}\text { Deficiência } \\
\mathrm{mm}\end{array}$ & Excedente \\
\hline \multirow{3}{*}{ Setembro/01 } & S1 & 10 & 23,2 & 0,0 & $-13,1$ & 0,0 \\
& S2 & 10 & 18,8 & 43,0 & 0,0 & 0,0 \\
& S3 & 10 & 22,3 & 5,4 & $-16,1$ & 0,0 \\
& O1 & 10 & 22,1 & 111,2 & 0,0 & 41,7 \\
Outubro/01 & O2 & 10 & 23,0 & 46,8 & 0,0 & 7,7 \\
& O3 & 11 & 23,2 & 15,3 & $-6,4$ & 0,0 \\
& N1 & 10 & 23,9 & 5,5 & $-20,2$ & 0,0 \\
Novembro/01 & N2 & 10 & 24,2 & 98,0 & 0,0 & 22,3 \\
& N3 & 10 & 26,0 & 48,9 & 0,0 & 5,0 \\
& D1 & 10 & 23,8 & 32,8 & $-0,2$ & 0,0 \\
Dezembro/01 & D2 & 10 & 24,9 & 64,2 & 0,0 & 20,0 \\
& D3 & 11 & 23,3 & 107,2 & 0,0 & 68,4 \\
& J1 & 10 & 24,8 & 117,0 & 0,0 & 79,1 \\
Janeiro/02 & J2 & 10 & 22,6 & 74,8 & 0,0 & 42,3 \\
& J3 & 11 & 26,2 & 128,4 & 0,0 & 84,5 \\
& F1 & 10 & 23,28 & 133,30 & 0,0 & 100,1 \\
Fevereiro/02 & F2 & 10 & 24,22 & 19,30 & $-2,2$ & 0,0 \\
& F3 & 8 & 24,36 & 35,30 & 0,0 & 0,0 \\
\hline
\end{tabular}

\subsubsection{Pastagem}

Os pastos começaram a ser implantados em setembro de 2000 através de sementes $\left(7 \mathrm{~kg} \mathrm{ha}^{-1}\right.$ de sementes puras e viáveis), sendo que em função de adversidades climáticas e inadequação da semeadora utilizada (baixa capacidade de campo operacional e baixa porcentagem de cobertura das sementes pelo solo), foi necessária a realização de duas novas semeaduras, uma ainda no mês de setembro de 2000 e outra em maio de 2001. Em janeiro de 2001 foi realizado um primeiro corte de uniformização das unidades experimentais, através de uma roçadora regulada para cortar de 3 a $5 \mathrm{~cm}$ da superfície do solo. Esse corte, além de muito severo, foi acompanhado de um período de deficiência hídrica moderada, resultando na morte de um grande número de touceiras, 
fato este que impossibilitou o início do experimento. Em diversas ocasiões durante o período de estabelecimento da brizanta foi necessário o controle de plantas daninhas na área, especialmente Cynodon spp. (Tifton-85, Florakirk e Coastcross), Setaria anceps (rabo de raposa), Portulaca oleracea L. (beldroega), Amaranthus sp. (caruru), Parthenium hysterophorus (losna branca) e Ipomoea sp. (corda-de-viola). Esse controle foi feito manualmente, com enxada, ou através do uso localizado de herbicidas. Duas adubações nitrogenadas foram realizadas durante o estabelecimento do pasto, as quais totalizaram $100 \mathrm{~kg} \mathrm{ha}^{-1}$, nas formas de uréia $\left(50 \mathrm{~kg} \mathrm{ha}^{-1}\right)$ e sulfato de amônio (50 $\left.\mathrm{kg} \mathrm{ha}^{-1}\right)$.

A partir de maio de 2001 a área encontrava-se satisfatoriamente ocupada por plantas de brizanta (cerca de 10 plantas $\mathrm{m}^{-2}$ ), embora os pastos não apresentassem as alturas planejadas para que as avaliações fossem iniciadas. O controle de plantas de Cynodon spp. ainda remanescentes, porém em quantidade notoriamente menor, foi feito através do pastejo seletivo da área experimental por equinos.

Em agosto de 2001 realizou-se um corte de uniformização a $8 \mathrm{~cm}$ do nível do solo através de roçadora. Os pastos foram permitidos crescer até que a altura respectiva de cada tratamento fosse atingida. No mês de outubro de 2001, todos os tratamentos apresentavam altura suficiente para o início do experimento.

\subsubsection{Animais}

Para a implantação e manutenção dos tratamentos experimentais foram utilizados bovinos (fêmeas) das raças Nelore (blocos I e III) e Canchim (II e IV), com massa corporal média aproximada de $200 \mathrm{~kg}$ no início do experimento, provenientes do rebanho do Departamento de Produção Animal da USP/ESALQ. 


\subsection{Métodos}

\subsubsection{Delineamento experimental e tratamentos}

O experimento foi realizado seguindo um delineamento de blocos completos casualizados, com quatro repetições. Os tratamentos corresponderam a quatro condições de pasto geradas por bovinos de corte e mantidas em steady state através de lotação contínua e taxa de lotação variável. Cada condição de pasto correspondeu a uma altura média de 10, 20, 30 e 40 cm mantida "constante" através de ajustes de carga (adição ou retirada de animais das unidades experimentais) durante o transcorrer do período experimental. Portanto, o experimento apresentou um total de 16 unidades experimentais ou parcelas (4 blocos x 4 unidades experimentais por bloco), com uma área média de $1.200 \mathrm{~m}^{2}$ cada, separadas por cerca de arame liso com quatro fios e 1,30 m de altura para delimitação dos piquetes (parcelas) e contenção dos animais. A área experimental total utilizada foi de cerca de 2,0 hectares (Figuras 5 e 6).

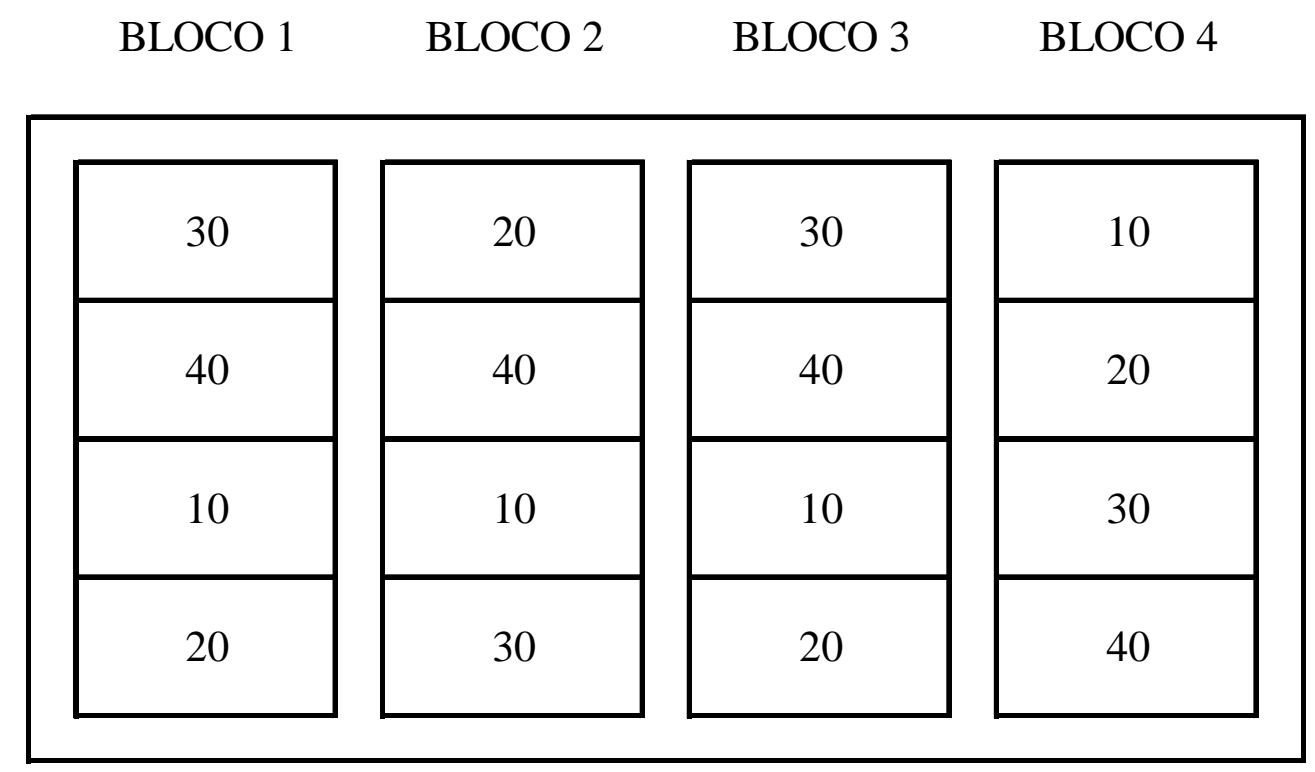

Figura 5 - Representação esquemática da distribuição dos tratamentos na área experimental. Alturas (cm): 10, 20, 30 e 40. 


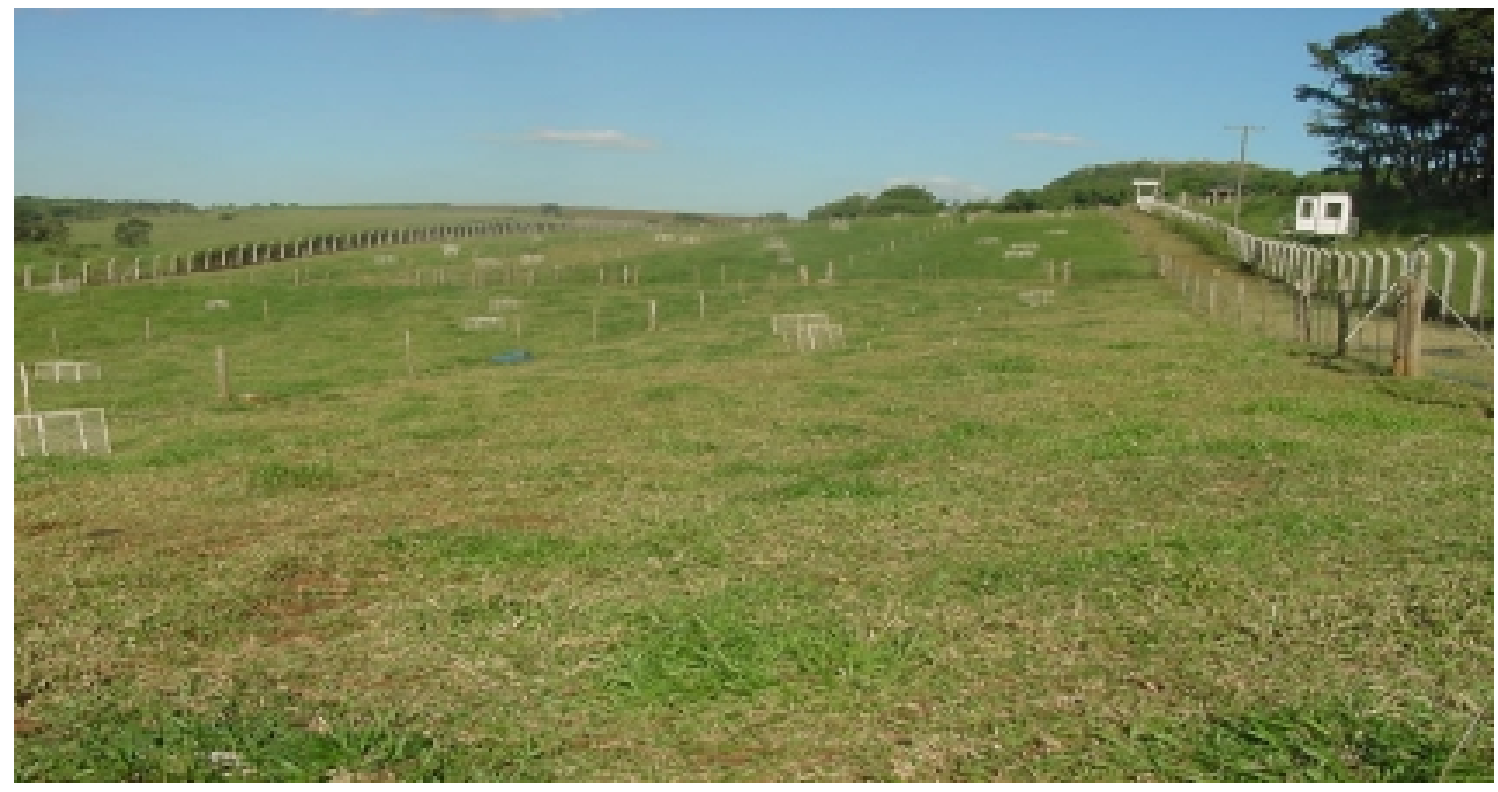

Figura 6 - Vista geral da área experimental após a implantação e início do experimento.

\subsubsection{Instalação e monitoramento das condições experimentais}

Em 27 de setembro 2001 os animais começaram a ser alocados às unidades experimentais que haviam atingido a altura predeterminada para cada tratamento. À medida que as demais unidades experimentais atingiam a altura desejada, animais eram adicionados, dando início ao pastejo. Em 26 de outubro todas as parcelas apresentaram condição para que fossem iniciadas as avaliações.

Durante a condução do experimento, de setembro de 2001 a fevereiro de 2002, foram realizadas duas adubações nitrogenadas com sulfato de amônio. A primeira em 30 de novembro (50 kg ha ${ }^{-1}$ ) e a segunda em 10 de janeiro $\left(45 \mathrm{~kg} \mathrm{ha}^{-1}\right)$. As quantidades de fertilizante aplicadas foram dimensionadas a fim de estimular o crescimento da pastagem para manter os pastos ocupados a maior parte do tempo, com no mínimo dois animais, visto que durante esse período as chances de ocorrência de limitações climáticas que pudessem comprometer a produtividade da pastagem eram mínimas. 
A altura média dos pastos (tratamentos) foi monitorada semanalmente através da tomada de 20 leituras de régua graduada em centímetros em cada parcela com o auxílio de uma transparência (duas vezes por semana), conforme descrito por Fagundes (1999). Os animais eram adicionados ou removidos das parcelas no caso da altura estar acima ou abaixo da desejada, respectivamente. As variações encontradas nas alturas e massas correspondentes dos tratamentos ao longo do período experimental são apresentadas nas Figuras 7 e 8, respectivamente. Considerando-se que as calibrações de altura e massa foram iniciadas somente no mês de novembro, época em que todas as condições de pasto foram atingidas, as massas de forragem mostradas na Figura 8 têm início em novembro.

A redução nas alturas médias dos tratamentos, principalmente nos pastos de $30 \mathrm{e}$ $40 \mathrm{~cm}$ a partir do dia 18/01/2002, ocorreu como conseqüência da manutenção de animais nos piquetes por tempo maior que o previsto no protocolo experimental de ajuste em taxa de lotação, justificado pela necessidade do término de avaliações de comportamento ingestivo sendo realizadas em experimento concomitante.

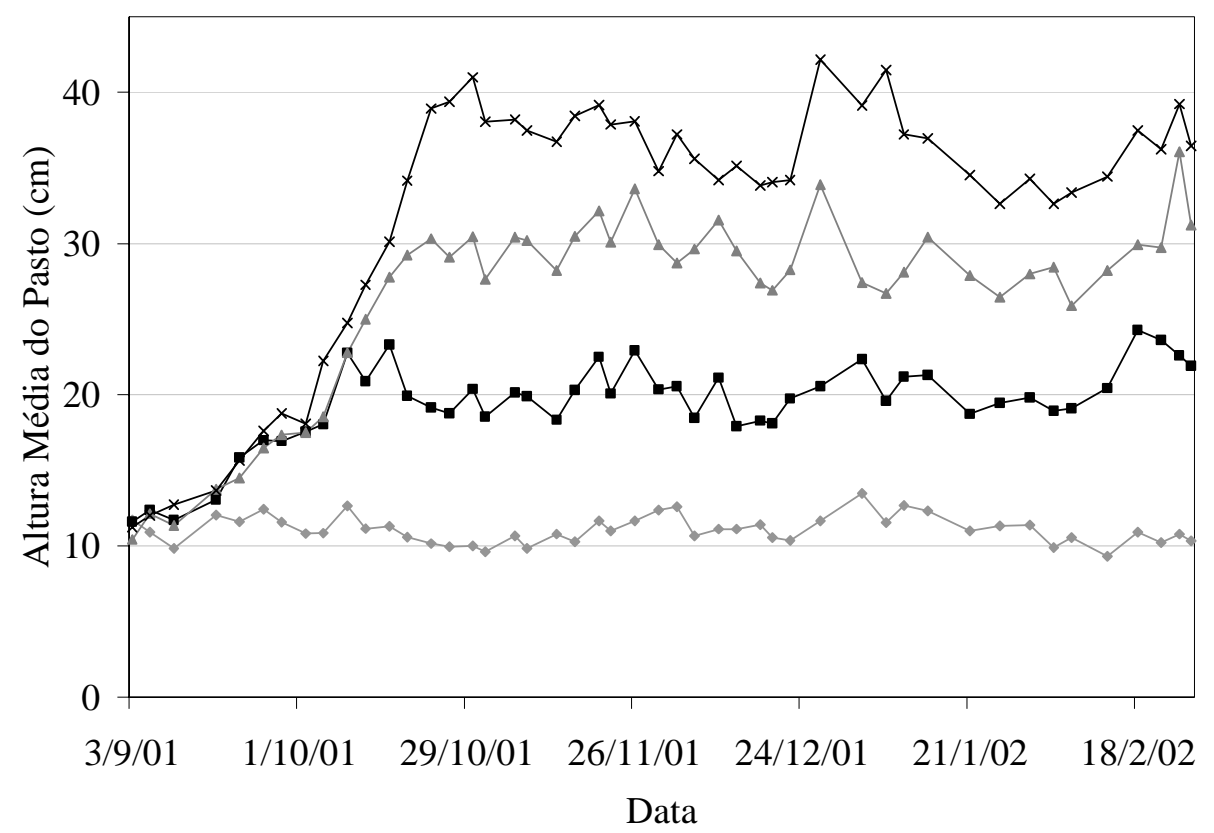

Figura 7 - Valores médios das alturas dos tratamentos $(\mathrm{cm})$ ao longo do período experimental. Alturas dos tratamentos (cm): 10, 20, 30 e 40. 


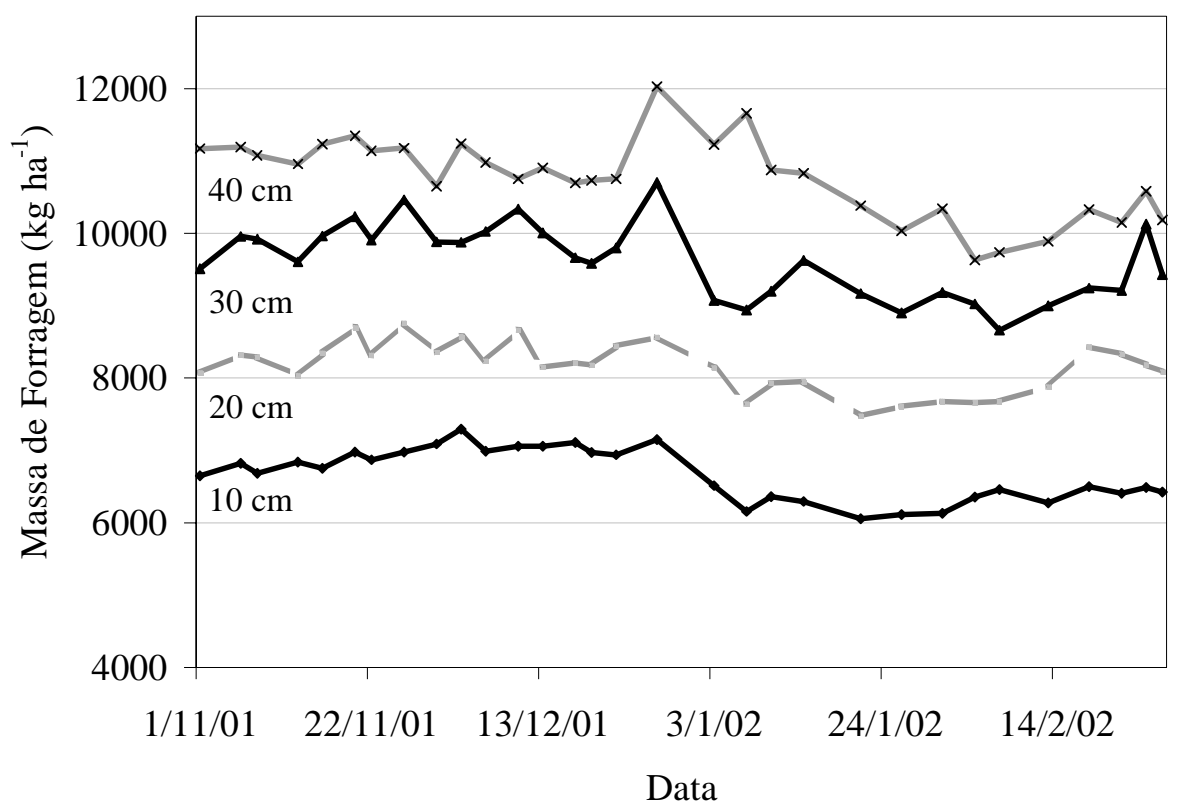

Figura 8 - Valores médios das massas de forragem $\left(\mathrm{kg} \mathrm{ha}^{-1}\right)$ dos tratamentos ao longo do período experimental. Alturas dos tratamentos (cm): 10, 20, 30 e 40.

\subsubsection{Calibração: altura x massa}

Uma vez ao mês era feita a calibração entre altura e massa de forragem, com a finalidade de relacionar a altura média do pasto com a massa de forragem existente e também determinar o acúmulo de forragem através de cálculo, minimizando assim a necessidade de amostragens destrutivas. Utilizando-se uma área retangular de 0,25 $\mathrm{m}^{2}$, foram escolhidos três pontos dentro de cada unidade experimental procurando-se, de forma consistente, a altura média, a menor e a maior altura do pasto no dia da amostragem. A estratégia de coleta dos três pontos (mais baixo, médio e mais alto) dentro de cada condição de pasto estudada possibilitou que uma amplitude significativa e representativa das situações (combinações entre massa de forragem e altura do pasto) fosse contemplada, possibilitando a geração de equações de calibração mais precisas. Dentro de cada área foi medida a altura da massa de forragem existente com o auxílio de régua e transparência e, posteriormente, a forragem foi cortada no nível do solo, lavada 
para eliminação de resíduos de terra e fezes, seca em estufa a $65^{\circ} \mathrm{C}$ até massa constante e pesada. Assim, depois de determinada a massa seca, foi estabelecida, através de regressão linear, a relação entre altura e massa da brizanta, baseada em 48 pontos de amostragem por mês, como demonstra a equação 1 abaixo:
$M F=a+b h$
equação (1) sendo:
MF = massa de forragem, em $\mathrm{kg} \mathrm{ha}^{-1}$;
$\mathrm{h}=$ altura, $\mathrm{em} \mathrm{cm}$.

\subsubsection{Acúmulo de forragem}

O acúmulo de forragem foi medido dentro de gaiolas de exclusão, em número de quatro por parcela (Figura 6), compreendendo uma área de aproximadamente 1,0 $\mathrm{m}^{2}$ $(140 \mathrm{~cm} \times 70 \mathrm{~cm})$ cada e observando-se um intervalo de 21 dias entre amostragens sucessivas. Após a amostragem, as gaiolas eram rotacionadas nas unidades experimentais e ancoradas em novos pontos representativos da condição do pasto (altura média) no momento do rodízio.

Os cálculos de acúmulo de forragem foram feitos com base no método agronômico da diferença, conforme a equação 2 (Davies et al., 1993):

$$
\mathrm{AF}=\mathrm{MFg}-\mathrm{MFp} \quad \text { equação (2), onde: }
$$

$\mathrm{AF}=$ acúmulo de forragem;

MFg = massa de forragem sob a gaiola, no último dia de exclusão;

MFp = massa de forragem sob a gaiola, no dia da colocação das gaiolas .

Os valores de massa de forragem (MF) usados nos cálculos de acúmulo foram estimados a partir das curvas de regressão linear entre altura e massa, conforme descrito na seção 3.2.3. 


\subsubsection{Distribuição relativa da ocupação do solo nas unidades experimentais}

Uma vez ao mês era realizada uma estimativa da ocupação do solo nas unidades experimentais, com a finalidade de acompanhar a evolução da distribuição de plantas de braquiária brizanta entre e dentro das condições de pasto estudadas durante o período experimental. Para tanto, era feito um caminhamento ao longo de duas diagonais em cada unidade experimental (linhas transectas) nas quais o observador determinava, passo a passo, e em função do que se encontrava sob a ponta do pé, a ocupação do solo dentro da parcela. As categorias utilizadas para caracterizar essa ocupação foram as seguintes: coroa (referindo-se a área basal da touceira), folhas (folhas e colmos sobre a superfície do solo), espaço vazio e plantas daninhas. A escolha desse método foi feita tendo-se em vista a não ocorrência de plantas daninhas arbustivas ou mesmo arbóreas, de modo que se espécies com esse hábito de crescimento estivessem presentes teria sido mais indicada a utilização de um método baseado na distribuição das massas das espécies vegetais encontradas na área.

Em função da finalidade descritiva e complementar dessa avaliação, os resultados obtidos não foram submetidos à análise estatística.

\subsection{6 Índice de área foliar (IAF) do pasto}

Para avaliação do IAF do pasto foram coletadas amostras de forragem contidas no interior de quatro retângulos $(25 \times 37 \mathrm{~cm})$ por unidade experimental, respeitando-se

um intervalo de quatro semanas entre amostragens sucessivas. A área amostrada correspondeu, sempre, a uma região da unidade experimental que estivesse com uma altura média semelhante àquela do tratamento em avaliação. A forragem foi cortada no nível do solo, acondicionada em sacos plásticos e refrigerada a $4^{\circ} \mathrm{C}$. As amostras foram então lavadas, sub-amostradas duas vezes e, nas sub-amostras, separadas todas as lâminas foliares verdes, as quais tinham sua área foliar determinada através de aparelho integrador de área foliar da marca LICOR, modelo LI-3100 (Figura 9). Em seguida, 
essas lâminas mais o material remanescente das sub-amostras e da amostra correspondente foram acondicionadas em sacos de papel, devidamente identificados, e levados à estufa de circulação forçada de ar para secagem a $65^{\circ} \mathrm{C}$ até massa constante, quando eram pesadas. Com os valores de área total das lâminas foliares de cada subamostra, sua massa correspondente e a massa do restante da sub-amostra foi possível calcular-se a área de folhas $\left(\mathrm{m}^{2}\right)$ por $\mathrm{kg}$ de massa seca de forragem. Esse valor, juntamente com a massa total de cada amostra (colhida num retângulo de 25 x $37 \mathrm{~cm}$ ) permitiu o cálculo da área de folhas $\left(\mathrm{m}^{2}\right)$ dentro da área do retângulo $\left(\mathrm{m}^{2}\right)$, ou seja, o IAF do pasto.

\subsubsection{Coleta de amostras para determinação de massa de raízes e parte áerea e teores de compostos de reserva}

\subsubsection{Amostragem e amostras}

As amostras de raízes e de parte aérea foram coletadas através de um cilindro de aço com $15 \mathrm{~cm}$ de diâmetro, que era colocado sobre a coroa da planta e, em seguida, introduzido a uma profundidade aproximada de $20 \mathrm{~cm}$ da superfície do solo. A amostra resultante, torrão de terra e vegetação correspondente (Figura 10), era imediatamente levada para laboratório e padronizada para uma profundidade de $10 \mathrm{~cm}$, retirando-se o excesso de terra e raízes. A parte aérea também era cortada a uma altura de $5 \mathrm{~cm}$ do nível do solo, descartando-se o excesso de material vegetativo. Foram amostrados seis pontos de cada unidade experimental, sendo o cilindro colocado em pontos onde a altura média era semelhante à do tratamento em avaliação.

O procedimento de amostragem foi repetido a cada quatro semanas durante todo o período experimental. Devido às variações nos teores de carboidratos de reserva (White, 1973) e de compostos nitrogenados (Schjoerring et al., 2002) nos órgãos de

acúmulo ao longo do dia, as amostragens foram realizadas consistentemente num mesmo horário, normalmente entre as 6:00 e 10:00 horas da manhã. 


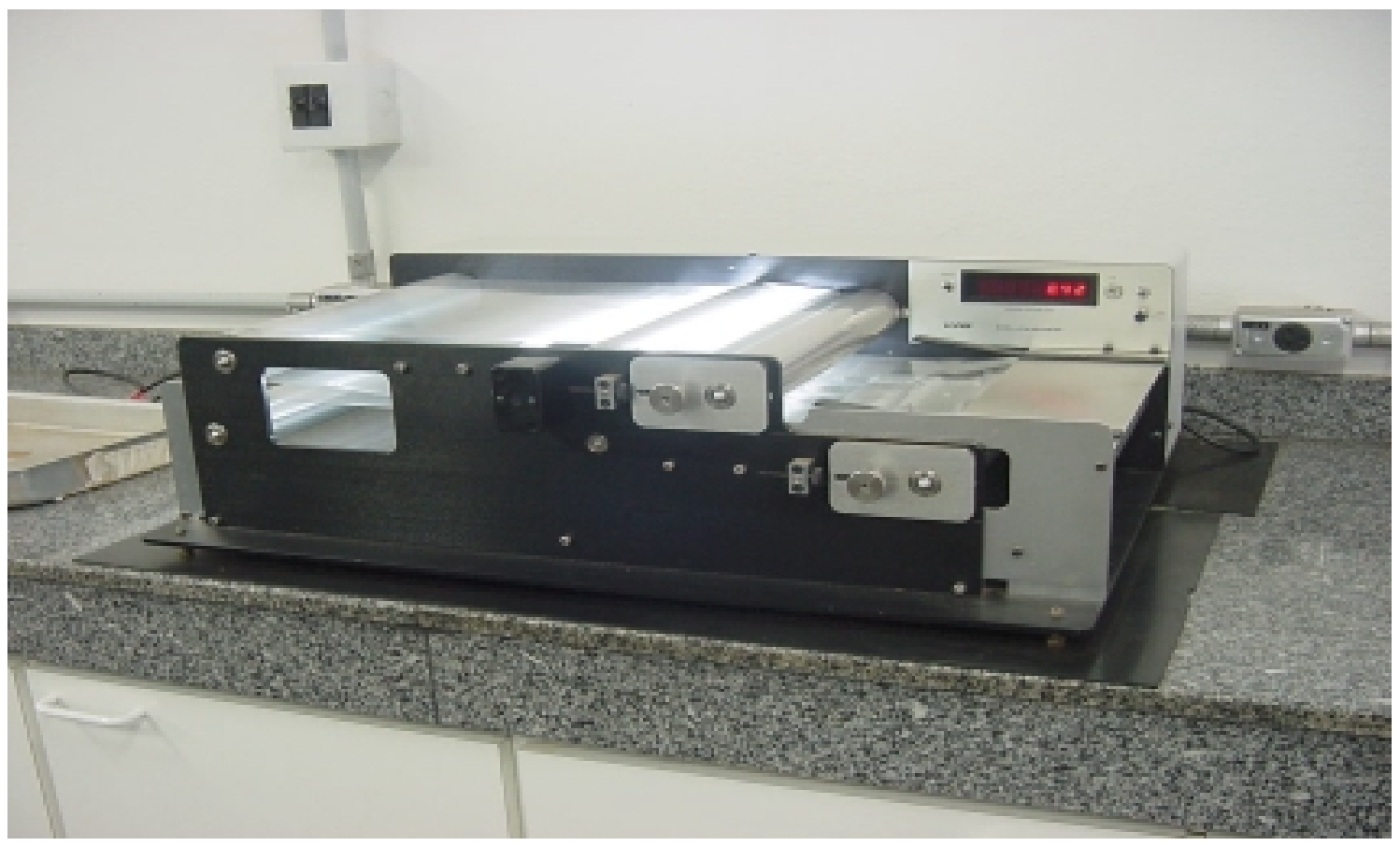

Figura 9 - Integrador de área foliar da marca LICOR, modelo LI-3100.

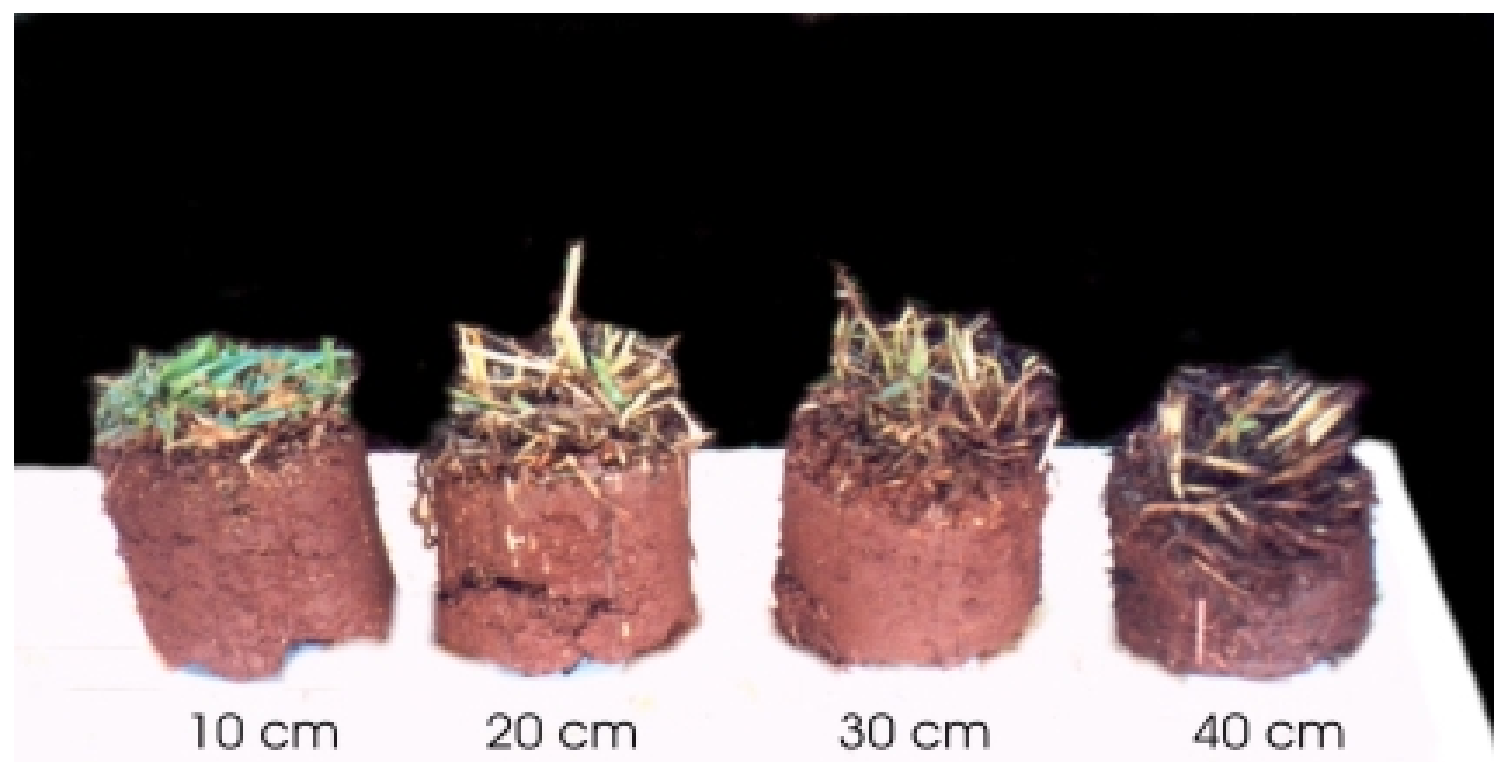

Figura 10 - Amostras para determinação de massas de órgãos e compostos de reserva. 


\subsubsection{Determinação da massa de raízes e de parte aérea}

As amostras obtidas conforme a descrição apresentada na seção anterior foram processadas cortando-se a forragem (bases dos colmos) no nível do solo, para a geração da porção de parte aérea, que foi lavada sendo, posteriormente, dividida em duas subamostras, que foram colocadas em bandejas de alumínio. Uma foi seca a sombra (determinação de compostos nitrogenados) e outra seguiu para secagem em estufa a $100^{\circ} \mathrm{C}$ por uma hora, com a finalidade de paralisar os processos respiratórios e enzimáticos, e depois a $65^{\circ} \mathrm{C}$ até massa constante. Após secas, ambas foram para pesagem em balança digital da marca Marte, modelo AK 10. A terra do torrão remanescente foi lavada em água corrente sob pressão sobre peneiras (malha de 300 mm) para separação das raízes. Após lavagem e obtenção das raízes, estas também foram subdivididas em duas porções e colocadas em bandejas de alumínio. Uma foi seca a sombra (determinação de compostos nitrogenados) e a outra seguiu para a secagem em estufa a $100^{\circ} \mathrm{C}$ por uma hora sendo, em seguida, passada para estufa a $65^{\circ} \mathrm{C}$ onde permaneceu até atingir massa constante. Após secagem, as amostras foram pesadas em balança digital da marca Marte, modelo AK 10. As massas de raízes e de parte aérea foram calculadas em relação à área de solo amostrada. Devido à forma com que a amostragem foi realizada (colocação do cilindro sobre a coroa da planta), os valores obtidos não consideraram a distribuição espacial real das plantas de brizanta nas condições de pasto estudadas, particularmente no que diz respeito à presença de espaços vazios, razão pela qual devem ser analisados com atenção e não permitem que extrapolações diretas sejam feitas sem os devidos cuidados. Esse fato não significa que o método de amostragem empregado foi inadequado. Revela apenas que o objetivo da análise foi estudar a variação nos teores e estoques de compostos de reserva existentes no sistema radicular e base dos colmos. 


\subsubsection{Determinação dos teores de compostos de reserva}

Após a pesagem, as amostras secas de raízes e parte aérea foram moídas em moinho tipo Wiley (peneira de $1 \mathrm{~mm}$ ) e acondicionadas em sacos de papel, devidamente identificados, os quais foram armazenados e posteriormente encaminhados para análise química.

\subsection{Carboidratos não estruturais}

As análises de carboidratos totais não estruturais (CNE) foram feitas seguindo o método de Smith (1969), descrito por Silva (1981). Esse método é baseado na digestão ácida das amostras por ácido sulfúrico e precipitação dos carboidratos por sulfato de cobre (Apêndice 1).

\subsection{Compostos nitrogenados}

Silveira (1985) apontou que as três principais frações de nitrogênio na planta são $\mathrm{N}$ inorgânico $\left(\mathrm{NH}_{4}{ }^{+}\right.$e $\left.\mathrm{NO}_{3}{ }^{-}\right), \mathrm{N}$ em aminoácidos (aminoácidos, aminas e amidas) e $\mathrm{N}$ protéico, sendo que neste trabalho foram determinados os teores de nitrogênio total, nitrogênio protéico solúvel, nitrogênio em aminoácidos (alfa aminoácidos), amônio e nitrato.

\subsection{Determinação do nitrogênio total ( $\mathbf{N}$ total)}

As análises de nitrogênio total ( $\mathrm{N}$ total) foram realizadas através do método volumétrico do micro Kjeldahl (AOAC, 1995 a), já utilizado para esse fim em plantas forrageiras por Gross (1988) e Soares Filho (1991). 


\subsection{Determinação do nitrogênio protéico solúvel (N solúvel)}

As amostras utilizadas para a determinação do nitrogênio solúvel sofreram um processo intenso de lavagem conforme descrito em Pereira \& Rossi Jr. (1996) e, em seguida, foram realizadas as determinações do nitrogênio total remanescente (nitrogênio insolúvel) nas amostras de acordo com o método descrito pela AOAC (1995 b). O nitrogênio solúvel foi obtido de forma indireta, através da subtração dos resultados de nitrogênio total, determinados conforme descrito em 3.2.7.3.2.1, pelos valores obtidos para o nitrogênio total remanescente da amostra (nitrogênio insolúvel).

\subsection{Determinação do nitrogênio em aminoácidos ( $\mathrm{N}$ aminoácidos)}

As determinações de $\mathrm{N}$ aminoácidos ( $\alpha$-aminoácidos) foram feitas a partir de um conjunto de adaptações feitas no método proposto por Kabat \& Mayer (1967) (Apêndice 2).

\subsection{Determinação do amônio $\left(\mathrm{NH}_{4}^{+}\right)$e nitrato $\left(\mathrm{NO}_{3}{ }^{-}\right)$}

As análises para a determinação de amônio e nitrato foram feitas segundo o método descrito por Tedesco et al. (1995).

\subsubsection{Determinação do nitrogênio total ( $\mathrm{N}$ total) em folhas}

Para determinação dos teores de $\mathrm{N}$ total em folhas, foram coletados 100 perfilhos por unidade experimental, respeitando-se um intervalo de quatro semanas entre amostragens sucessivas. Os perfilhos foram cortados próximo ao nível do solo, sendo imediatamente acondicionados em sacos de plástico previamente identificados, e 
refrigerados a $4^{\circ} \mathrm{C}$. Em seguida, as lâminas foliares foram separadas manualmente em três categorias: folhas senescentes, maduras e em expansão. Posteriormente, essas lâminas foram armazenadas em sacos de papel identificados e colocadas em estufa a $65^{\circ} \mathrm{C}$ até atingir massa constante. Após secagem, as amostras de folhas eram moídas em moinho do tipo Wiley (peneira de $1 \mathrm{~mm}$ ) e acondicionadas em sacos plásticos, devidamente identificados, que foram armazenados e, posteriormente, encaminhados para análise.

A determinação do nitrogênio total em folhas (senescentes, maduras e em expansão) foi realizada através da combustão da amostra segundo o método de Dumas, utilizando-se um auto-analisador de nitrogênio, da marca LECO, modelo FP-528 (Wiles et al., 1998).

\subsubsection{Análise estatística dos dados}

Os dados foram analisados utilizando-se o procedimento MIXED do pacote estatístico SAS $^{\circledR}$ (Statistical Analysis System), versão 8.0 para Windows ${ }^{\circledR}$, uma vez que todas as variáveis em estudo foram coletadas ao longo de vários meses (SAS Institute, 2002). Especificamente para a análise dos dados relativos ao acúmulo de forragem durante o período experimental, utilizou-se o procedimento GLM (General Linear Models) do pacote estatístico SAS ${ }^{\circledR}$, versão 8.0 para Windows ${ }^{\circledR}$, visto que esses dados foram obtidos a partir do compilamento dos resultados das taxas de acúmulo mensais.

Para efeito de comparação de médias entre tratamentos foi utilizado o “LSMEANS”, com um nível de significância de $10 \%$. 


\section{RESULTADOS E DISCUSSÃO}

\section{1 Índice de área foliar (IAF)}

Os dados referentes ao IAF são apresentados na Tabela 4 e Figuras 11 e 12. Houve efeito de altura do pasto $(\mathrm{P}=0,0217)$ e mês $(\mathrm{P}=0,0006)$, não tendo sido verificado efeito da interação altura $\mathrm{x}$ mês $(\mathrm{P}=0,3438)$. Os valores médios de IAF ao longo do período experimental variaram entre $1,2(10 \mathrm{~cm}$, dezembro) e 6,0 (40 cm, janeiro). $\mathrm{O}$ maior valor médio de IAF dentre as alturas de pasto estudadas foi alcançado em $30 \mathrm{~cm}$ $(4,0)$, a qual não diferiu de $20(3,5)$ e $40 \mathrm{~cm}(3,8)$, embora essas tenham sido diferentes da altura de $10 \mathrm{~cm}(1,7)$. Com relação ao mês, o maior valor médio de IAF foi observado em janeiro $(4,5)$, sendo que esse valor diferiu dos meses de novembro $(2,5)$, dezembro $(3,0)$ e fevereiro $(3,0)$. Não houve diferença para os valores de IAF entre esses meses.

O comportamento dos valores médios de IAF correspondente às alturas de pasto durante o período experimental foi inicialmente crescente, atingindo um platô entre as alturas de 20 e $30 \mathrm{~cm}$ (Figura 11). De uma forma geral, esse padrão de comportamento foi consistente durante os meses em que a planta forrageira esteve em estádio de desenvolvimento vegetativo (novembro e dezembro) e durante os meses de desenvolvimento reprodutivo (janeiro e fevereiro) (Figura 12). Deve-se ressaltar que os dados de IAF obtidos durante o estádio reprodutivo foram consistentemente superiores àqueles observados durante o estádio vegetativo, embora semelhantes estatisticamente. Isso se deveu principalmente à influência dos maiores valores de IAF obtidos durante o mês de janeiro em comparação aos meses de novembro e dezembro. 
Tabela 4. Índice de área foliar (IAF) de braquiária brizanta mantida em quatro alturas de pasto, de novembro de 2001 a fevereiro de 2002.

\begin{tabular}{|c|c|c|c|c|c|c|}
\hline \multirow{2}{*}{ Mês } & \multicolumn{4}{|c|}{ Altura do Pasto $(\mathrm{cm})$} & \multirow{2}{*}{ Média } & \multirow{2}{*}{$\mathrm{EPM}^{*}$} \\
\hline & 10 & 20 & 30 & 40 & & \\
\hline Novembro & 1,6 & 2,4 & 3,1 & 2,9 & $2,5 \mathrm{~B}$ & 0,33 \\
\hline Dezembro & 1,2 & 3,5 & 3,7 & 3,8 & 3,0 B & 0,33 \\
\hline Janeiro & 2,3 & 4,9 & 4,7 & 6,0 & $4,5 \mathrm{~A}$ & 0,36 \\
\hline Fevereiro & 1,9 & 3,1 & 4,5 & 2,7 & $3,0 \mathrm{~B}$ & 0,33 \\
\hline Média & $1,7 \mathrm{~b}$ & 3,5 a & $4,0^{\mathrm{a}}$ & 3,8 a & & \\
\hline EPM* & 0,45 & 0,45 & 0,45 & 0,45 & & \\
\hline
\end{tabular}

*EPM - Erro padrão da média.

Médias na linha seguidas de mesmas letras minúsculas não diferem entre si $(\mathrm{P}>0,10)$.

Médias na coluna seguidas de mesmas letras maiúsculas não diferem entre si $(\mathrm{P}>0,10)$.

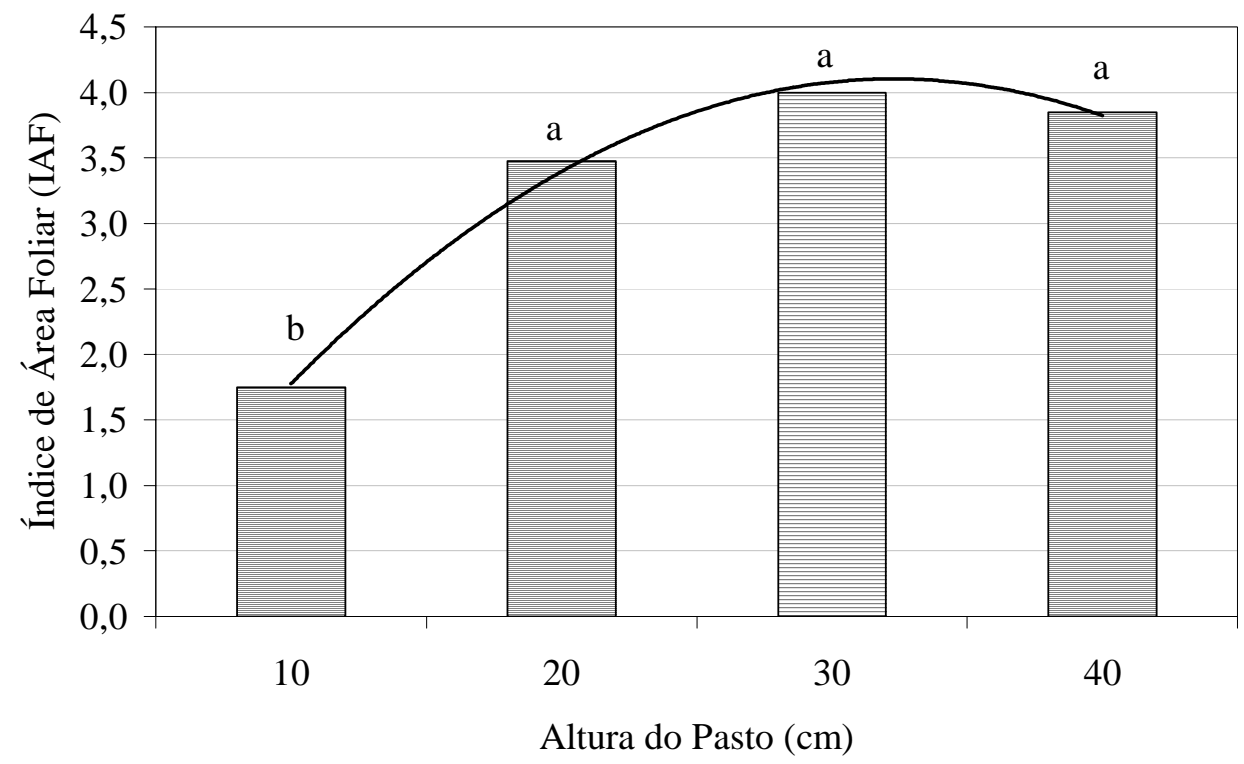

— Linha de tendência das médias

Figura 11 - Índice de área foliar (IAF) de braquiária brizanta mantida em diferentes alturas de pasto. 


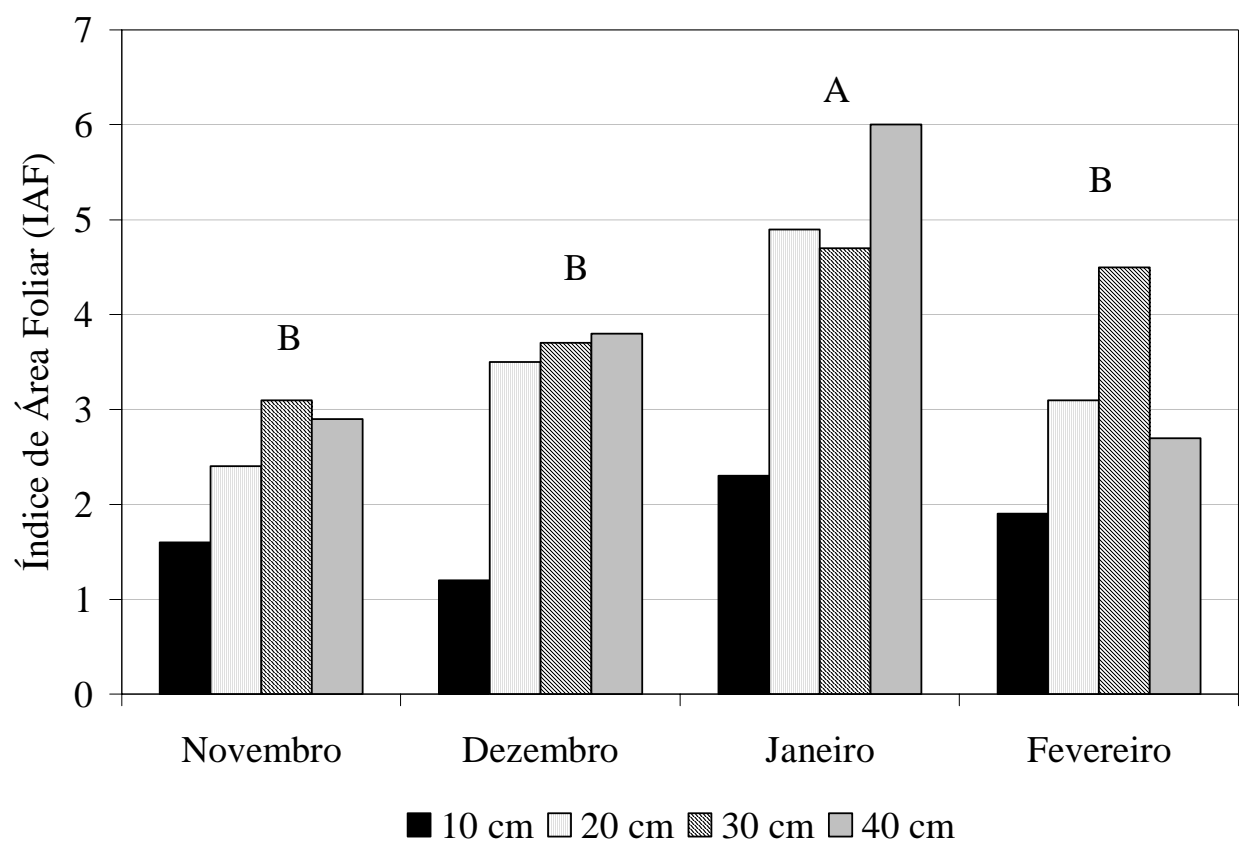

Figura 12 - Índice de área foliar (IAF) em pastos de braquiária brizanta, de novembro de 2001 a fevereiro de 2002.

A redução no IAF do pasto de $40 \mathrm{~cm}$ relativamente ao de $30 \mathrm{~cm}$ em fevereiro ocorreu como consequência da manutenção de animais nos piquetes por tempo maior do que o previsto no protocolo experimental de ajuste em taxa de lotação, justificado pela necessidade do término de avaliações de comportamento ingestivo sendo realizadas em experimento concomitante, conforme relatado no item 3.2.2 e Figura 7. Esse fato deve ter levado os animais a removerem seletivamente lâminas foliares em relação aos colmos, de forma que o IAF do pasto diminuiu.

A estabilização dos valores de IAF a partir da altura de $20 \mathrm{~cm}$ esteve diretamente associada com a interceptação luminosa pelo dossel, ou seja, a partir dessa altura houve a interceptação de praticamente toda a luz incidente ${ }^{1}(97 \%)$ e, portanto, não seria esperado que aumentos adicionais em IAF a partir desse ponto resultassem em benefício

\footnotetext{
${ }^{1}$ MOLAN, L.K. (Escola Superior de Agricultura "Luiz de Queiroz", Piracicaba, SP). Estrutura do dossel e interceptação luminosa em pastos de Brachiaria brizantha cv. Marandu. (projeto de mestrado em andamento)
} 
algum para a planta forrageira do ponto de vista morfofisiológico, fato ratificado pelos valores de IAF obtidos nas alturas de 30 e $40 \mathrm{~cm}$. Esses resultados revelaram não ter existido diferença alguma entre as condições de pasto de 20,30 e $40 \mathrm{~cm}$, ao passo que a altura de $10 \mathrm{~cm}$ apresentou um menor valor de IAF. O padrão de comportamento observado confirmou a expectativa de que pastos mantidos mais altos devem apresentar valores maiores de IAF (Tabela 4, Figuras 11 e 12), corroborando os resultados apresentados por Gomide et al. (1997), Fagundes (1999), Fagundes et al. (1999 e 2001) e Grasselli et al. (2000).

Todavia, os dados disponíveis na literatura nacional relativos à relação entre IAF e altura do pasto para outras gramíneas forrageiras tropicais permitem inferir que o IAF descreve um padrão crescente e linear, diferentemente do que foi observado neste experimento, conforme foi relatado para braquiária decumbens (Gomide et al., 1997; Grasselli et al., 2000) e para cultivares de Cynodon (Fagundes, 1999; Fagundes et al., 1999, 2001). Grasselli et al. (2000), avaliando braquiária decumbens sob lotação contínua e taxa de lotação variável utilizando novilhos azebuados para a manutenção das condições do pasto dentro de uma amplitude de alturas variando entre 10 e $25 \mathrm{~cm}$ (10, 15,20 e $25 \mathrm{~cm}$ ), concluíram que o IAF que maximizaria a produtividade da pastagem seria obtido acima dos $25 \mathrm{~cm}$, condição essa não contemplada no experimento. Fagundes (1999) e Fagundes et al. (1999, 2001), trabalhando com pastos de Tifton-85, Florakirk e Coastcross sob lotação contínua de ovinos e taxa de lotação variável para manutenção das condições experimentais representadas pelas alturas de pasto de 5, 10, 15 e $20 \mathrm{~cm}$, relataram que um padrão de comportamento linear e crescente foi observado para o IAF em relação as alturas de pasto estudadas quando foi considerada a média dos três cultivares durante os meses de novembro de 1998 a fevereiro de 1999.

Em ambos os trabalhos, a interceptação de luz pelo dossel atingiu valores inferiores a 95\%, interceptação na qual a taxa de crescimento da cultura está próxima de um valor máximo (Brown \& Blaser, 1968). Para braquiária decumbens, Grasselli et al. (2000) relataram um valor máximo de interceptação de luz igual a 90,5\% obtido na altura de $25 \mathrm{~cm}$, o que reforça o fato de que as amplitudes de condição de pasto 
utilizadas não foram grandes o suficiente para permitir a maximização dessa variável resposta.

No caso do gênero Cynodon, o cultivar Tifton-85 apresentou valores de interceptação de luz próximos ou até superiores a 95\%. No entanto, esses valores foram observados somente na altura de pasto de $20 \mathrm{~cm}$. Para Florakirk e Coastcross, os valores máximos de interceptação de luz alcançados foram de 90,9 e 86,3\%, respectivamente, também na altura de $20 \mathrm{~cm}$ (Fagundes, 1999; Fagundes et al., 1999). Novamente, a amplitude de condições de pasto utilizada não permitiu que um valor máximo de IAF fosse obtido. A conclusão desse trabalho destacou dois aspectos fundamentais em termos de ecofisiologia de pastagens: (1) plantas forrageiras apresentam padrões específicos de resposta, mesmo em se tratando de plantas pertencentes ao mesmo gênero, muito embora os padrões de comportamento relativo aos aspectos de morfofisiologia sejam universais, fato esse que merece ser considerado com muita atenção quando da comparação de resultados de pesquisa e, (2) as alturas utilizadas não foram capazes de contemplar uma amplitude de respostas de IAF onde o padrão de comportamento dessa variável fosse satisfatoriamente obtido, sobremaneira para o cultivar Coastcross, visto que apresentou os menores valores de IAF e interceptação luminosa consistentemente ao longo do período experimental.

Com relação à época do ano, o maior valor de IAF obtido no mês de janeiro pode ser justificado pela associação entre a realização de uma adubação nitrogenada (45 $\mathrm{kg} \mathrm{ha}^{-1} \mathrm{~N}$, na de sulfato de amônio) no início do mês (10/01/2002) visando estimular o crescimento da pastagem para a manutenção de um mínimo de animais na área (Figura 4), e um aumento marcante na precipitação em comparação com os outros meses (Tabela 2 e Figura 2). As variações correspondentes em temperatura mínima, média e máxima e radiação global foram pequenas, não justificando, dessa forma, o aumento ocorrido em IAF no mês de janeiro. Adicionalmente, a possibilidade de ocorrência de maiores valores de IAF para uma mesma altura de pasto é reconhecida em situações onde as plantas encontram-se em fase de desenvolvimento reprodutivo (Robson et al., 1988), fato esse característico dos meses de janeiro e fevereiro neste experimento. 
Embora resultados de IAF obtidos especificamente em trabalhos com braquiária brizanta sejam encontrados na literatura nacional (Alcântara, 1987; Portes et al., 2000) variando de 1 até 15, ressalta-se que esses valores não foram gerados em experimentos planejados com o objetivo de se entender aspectos de comunidades de plantas forrageiras em pastagens sendo, por esse motivo, inconsistentes e incompatíveis com o tipo de discussão relativo a este experimento.

\subsection{Massa de raízes e de parte aérea}

Os valores das massas de partes da planta apresentados nesta seção, assim como aqueles relativos aos estoques de reservas que serão apresentados e discutidos adiante, foram expressos em quilogramas por metro quadrado $\left(\mathrm{kg} \mathrm{m}^{-2}\right)$, visto que essa expressão indica a unidade de área para qual essas massas e estoques foram calculados. Adicionalmente, as massas de raízes e da parte aérea foram quantificadas com o intuito principal de se determinar os estoques dos compostos de reserva e, dessa forma, se restringiram à profundidade de $10 \mathrm{~cm}$.

Os resultados referentes às massas de raízes e de parte aérea são mostrados na Tabela 5 e nas Figuras 13 e 14. Houve efeito de altura de pasto ( $\mathrm{P}=0,0411)$, mês $(\mathrm{P}<0,0001)$, parte da planta $(\mathrm{P}<0,0001)$ e das interações altura x mês $(\mathrm{P}=0,0658)$, altura $\mathrm{x}$ parte da planta $(\mathrm{P}=0,0528)$, parte da planta x mês $(\mathrm{P}<0,0001)$ e altura $\mathrm{x}$ parte da planta $\mathrm{x}$ mês $(\mathrm{P}=0,0388)$. Os valores de massa de raízes ao longo do período experimental variaram entre 0,616 (40 cm, novembro e dezembro) e 1,300 $\mathrm{kg} \mathrm{m}^{-2}$ (40 cm, setembro). Os valores relativos à massa de parte aérea variaram entre 1,031 (40 cm, dezembro) e $3,061 \mathrm{~kg} \mathrm{~m}^{-2}$ (20 cm, outubro). A massa total de órgãos de reserva para a altura de pasto de $10 \mathrm{~cm}\left(3,103 \mathrm{~kg} \mathrm{~m}^{-2}\right)$ não diferiu da média de $20 \mathrm{~cm}\left(3,003 \mathrm{~kg} \mathrm{~m}^{-2}\right)$, embora tenha sido estatisticamente diferente das alturas de pasto de $30\left(2,680 \mathrm{~kg} \mathrm{~m}^{-2}\right)$ e $40 \mathrm{~cm}(2,492$ $\mathrm{kg} \mathrm{m}^{-2}$ ). A massa relativa à altura de $20 \mathrm{~cm}$, por sua vez, não diferiu de $30 \mathrm{~cm}$, embora tenha sido maior que a da altura de $40 \mathrm{~cm}$. As massas das alturas de pasto de 30 e $40 \mathrm{~cm}$ não diferiram entre si (Figura 13). 
Tabela 5. Massa $\left(\mathrm{kg} \mathrm{m}^{-2}\right)$ do sistema radicular (SR) e da parte aérea (PA) de braquiária brizanta mantida em quatro alturas de pasto, de setembro de 2001 a fevereiro de 2002.

\begin{tabular}{|c|c|c|c|c|c|c|c|c|c|c|}
\hline \multirow{2}{*}{$\begin{array}{l}\text { Altura do } \\
\text { Pasto }\end{array}$} & \multicolumn{6}{|c|}{ Parte da Planta } & \multirow{2}{*}{\multicolumn{3}{|c|}{ Média }} & \multirow{2}{*}{$\begin{array}{c}\text { Média } \\
\text { do Mês }\end{array}$} \\
\hline & & \multicolumn{2}{|c|}{ SR } & & \multicolumn{2}{|c|}{ PA } & & & & \\
\hline & & & & Sete & mbro & -2001 & & \multirow[b]{2}{*}{ A } & \multirow[b]{2}{*}{$(0,1641)$} & \multirow[b]{3}{*}{$1,878^{\mathrm{A}^{\prime}}$} \\
\hline 10 & 0,809 & $\mathrm{Bb}$ & $(0,1763)$ & 2,895 & $\mathrm{ABa}$ & $(0,2772)$ & 1,852 & & & \\
\hline 20 & 1,108 & $\mathrm{ABb}$ & $(0,1525)$ & 2,913 & $\mathrm{Aa}$ & $(0,1388)$ & 2,010 & A & $(0,1028)$ & \\
\hline 30 & 1,105 & $\mathrm{ABb}$ & $(0,1763)$ & 2,687 & $\mathrm{ABa}$ & $(0,5335)$ & 1,896 & A & $(0,2809)$ & \multirow[b]{2}{*}{$(0,0967)$} \\
\hline 40 & 1,300 & $\mathrm{Ab}$ & $(0,1763)$ & 2,206 & $\mathrm{Ba}$ & $(0,3184)$ & 1,753 & A & $(0,1817)$ & \\
\hline Média & 1,081 & $\mathrm{~b}$ & $(0,0853)$ & 2,675 & & $(0,1735)$ & & & & \\
\hline \multicolumn{11}{|c|}{ Outubro - 2001} \\
\hline 10 & 0,866 & $\mathrm{Bb}$ & $(0,1134)$ & 2,897 & Aa & $(0,3665)$ & 1,881 & A & $(0,1918)$ & \multirow{5}{*}{$\begin{array}{l}1,878^{A^{\prime}} \\
(0,1050)\end{array}$} \\
\hline 20 & 1,069 & $\mathrm{ABb}$ & $(0,1208)$ & 3,061 & Aa & $(0,3894)$ & 2,065 & A & $(0,2038)$ & \\
\hline 30 & 1,163 & $\mathrm{Ab}$ & $(0,1134)$ & 2,306 & Aa & $(0,4878)$ & 1,734 & A & $(0,2504)$ & \\
\hline 40 & 1,002 & $\mathrm{ABb}$ & $(0,1134)$ & 2,662 & Aa & $(0,3576)$ & 1,832 & A & $(0,1876)$ & \\
\hline Média & 1,025 & $\mathrm{~b}$ & $(0,0577)$ & 2,731 & & $(0,2018)$ & & & & \\
\hline \multicolumn{11}{|c|}{ Novembro - 2001} \\
\hline 10 & 0,756 & $\mathrm{Ab}$ & $(0,0998)$ & 2,268 & $\mathrm{Aa}$ & $(0,2805)$ & 1,512 & A & $(0,1489)$ & \multirow{5}{*}{$\begin{array}{l}1,211^{\mathrm{B}^{\prime}} \\
(0,0693)\end{array}$} \\
\hline 20 & 0,815 & $\mathrm{Ab}$ & $(0,1002)$ & 1,603 & $\mathrm{Ba}$ & $(0,2367)$ & 1,209 & $\mathrm{AB}$ & $(0,1286)$ & \\
\hline 30 & 0,749 & $\mathrm{Ab}$ & $(0,1004)$ & 1,686 & $\mathrm{ABa}$ & $(0,256)$ & 1,218 & $\mathrm{AB}$ & $(0,1374)$ & \\
\hline 40 & 0,616 & $\mathrm{Ab}$ & $(0,1004)$ & 1,196 & $\mathrm{Ba}$ & $(0,2587)$ & 0,906 & B & $(0,1388)$ & \\
\hline Média & 0,734 & $\mathrm{~b}$ & $(0,0501)$ & 1,688 & $\mathrm{a}$ & $(0,1292)$ & & & & \\
\hline \multicolumn{11}{|c|}{ Dezembro - 2001} \\
\hline 10 & 1,133 & $\mathrm{Ab}$ & $(0,1517)$ & 2,038 & $\mathrm{Aa}$ & $(0,1288)$ & 1,585 & A & $(0,0993)$ & \multirow{5}{*}{$\begin{array}{l}1,178^{\mathrm{B}^{\prime} \mathrm{C}^{\prime}} \\
(0,0502)\end{array}$} \\
\hline 20 & 1,202 & $\mathrm{Aa}$ & $(0,1987)$ & 1,046 & $\mathrm{Ca}$ & $(0,1133)$ & 1,124 & B & $(0,1145)$ & \\
\hline 30 & 0,913 & $\mathrm{ABb}$ & $(0,1398)$ & 1,445 & $\mathrm{Ba}$ & $(0,1354)$ & 1,179 & B & $(0,0971)$ & \\
\hline 40 & 0,616 & $\mathrm{Bb}$ & $(0,1398)$ & 1,031 & $\mathrm{Ca}$ & $(0,1107)$ & 0,824 & $\mathrm{C}$ & $(0,0889)$ & \\
\hline Média & 0,966 & $\mathrm{~b}$ & $(0,0797)$ & 1,390 & $\mathrm{a}$ & $(0,0614)$ & & & & \\
\hline \multicolumn{11}{|c|}{ Janeiro - 2002} \\
\hline 10 & 0,981 & $\mathrm{Ab}$ & $(0,0934)$ & 1,627 & $\mathrm{Aa}$ & $(0,1166)$ & 1,304 & $\mathrm{AB}$ & $(0,0743)$ & \multirow{5}{*}{$\begin{array}{l}1,235^{\mathrm{B}} \\
(0,0440)\end{array}$} \\
\hline 20 & 0,909 & $\mathrm{Ab}$ & $(0,0775)$ & 1,829 & Aa & $(0,1724)$ & 1,369 & A & $(0,0947)$ & \\
\hline 30 & 0,860 & $\mathrm{Ab}$ & $(0,0799)$ & 1,415 & Aa & $(0,1897)$ & 1,138 & $\mathrm{AB}$ & $(0,1032)$ & \\
\hline 40 & 0,798 & $\mathrm{Ab}$ & $(0,0799)$ & 1,458 & Aa & $(0,1315)$ & 1,128 & B & $(0,0767)$ & \\
\hline Média & 0,887 & b & $(0,0414)$ & 1,582 & $\mathrm{a}$ & $(0,776)$ & & & & \\
\hline \multicolumn{11}{|c|}{ Fevereiro - 2002} \\
\hline 10 & 0,643 & $\mathrm{Ab}$ & $(0,0977)$ & 1,710 & $\mathrm{ABa}$ & $(0,1573)$ & 1,177 & A & $(0,0927)$ & \multirow{5}{*}{$\begin{array}{l}1,080^{C^{\prime}} \\
(0,0538)\end{array}$} \\
\hline 20 & 0,619 & $\mathrm{Ab}$ & $(0,2073)$ & 1,842 & Aa & $(0,1741)$ & 1,231 & A & $(0,1353)$ & \\
\hline 30 & 0,663 & $\mathrm{Ab}$ & $(0,1259)$ & 1,091 & $\mathrm{Ba}$ & $(0,1431)$ & 0,877 & B & $(0,0946)$ & \\
\hline 40 & 0,648 & $\mathrm{Ab}$ & $(0,1281)$ & 1,421 & $\mathrm{Ba}$ & $(0,1593)$ & 1,035 & $\mathrm{AB}$ & $(0,1024)$ & \\
\hline Média & 0,643 & $\mathrm{~b}$ & $(0,0725)$ & 1,516 & $\mathrm{a}$ & $(0,0793)$ & & & & \\
\hline
\end{tabular}

Valores entre parênteses indicam o Erro Padrão da Média (EPM).

Médias na linha seguidas de mesmas letras minúsculas não diferem entre si $(\mathrm{P}>0,10)$.

Médias na coluna seguidas de mesmas letras maiúsculas não diferem entre si $(\mathrm{P}>0,10)$. 


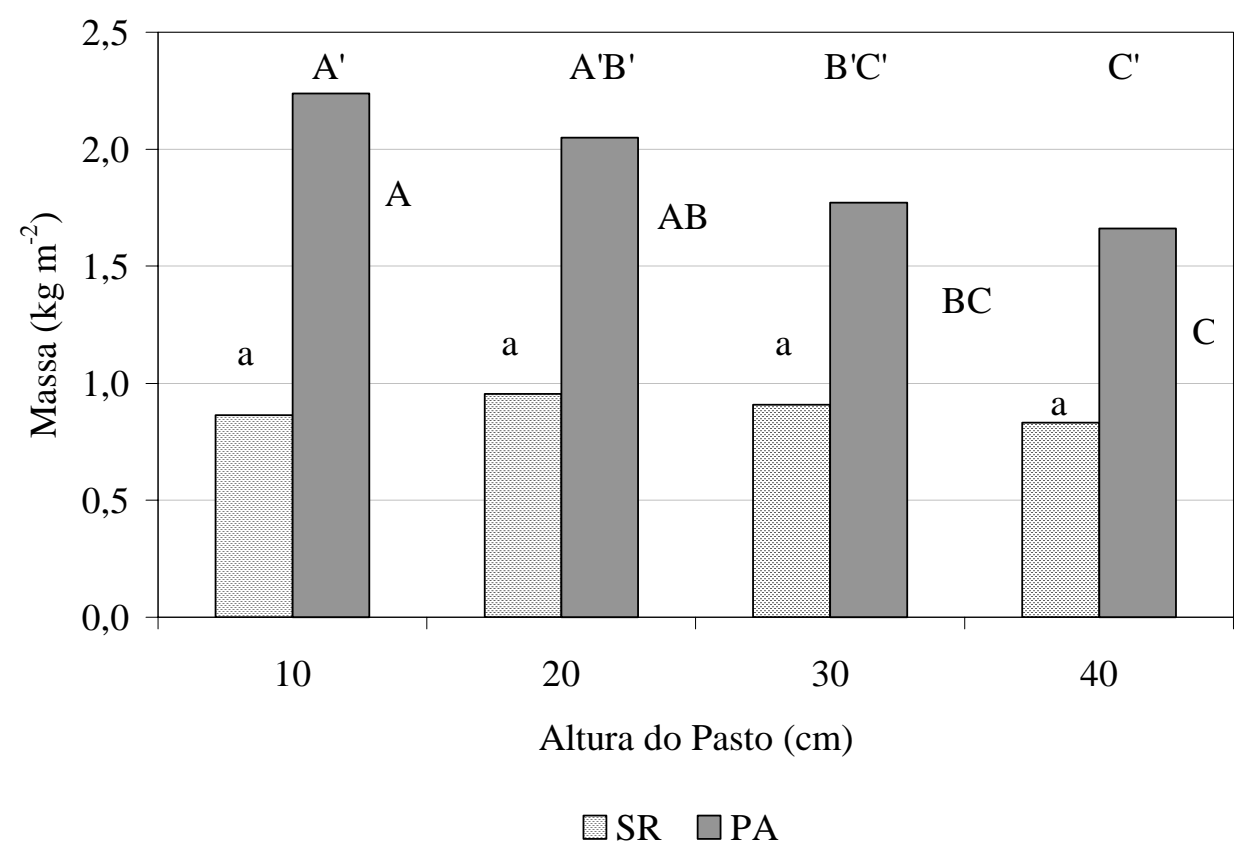

Figura 13 - Massa de raízes (SR) e da parte aérea (PA) de braquiária brizanta mantida em diferentes alturas de pasto.

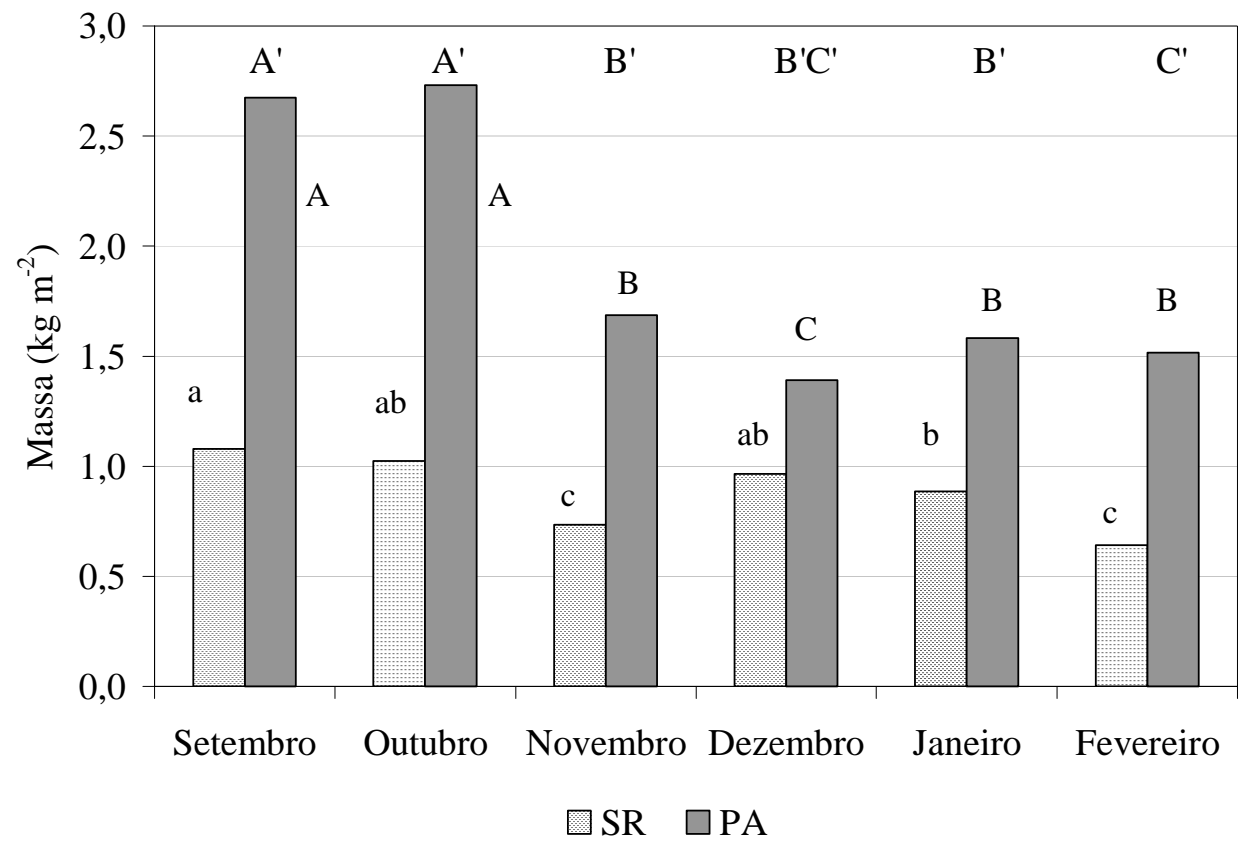

Figura 14 - Massa de raízes (SR) e da parte aérea (PA) em pastos de braquiária brizanta, de setembro de 2001 a fevereiro de 2002. 
Com relação à parte da planta, a maior média geral do experimento foi observada para a massa da parte aérea $\left(1,931 \mathrm{~kg} \mathrm{~m}^{-2}\right)$ em relação a massa de raízes $\left(0,889 \mathrm{~kg} \mathrm{~m}^{-2}\right)$ (Figuras 13 e 14). O maior valor médio encontrado para a massa de raízes foi obtido em setembro $\left(1,081 \mathrm{~kg} \mathrm{~m}^{-2}\right)$, o qual não diferiu daqueles observados para os meses de outubro (1,025 $\left.\mathrm{kg} \mathrm{m}^{-2}\right)$ e dezembro $\left(0,966 \mathrm{~kg} \mathrm{~m}^{-2}\right)$ (Figura 14). As massas de setembro e outubro diferiram daquelas observadas para novembro $\left(0,734 \mathrm{~kg} \mathrm{~m}^{-2}\right)$, janeiro $(0,887$ $\left.\mathrm{kg} \mathrm{m}^{-2}\right)$ e fevereiro $\left(0,643 \mathrm{~kg} \mathrm{~m}^{-2}\right)$, ao passo que dezembro não diferiu de janeiro. As massas de novembro e fevereiro não diferiram entre si (Figura 14). O maior valor médio relativo à massa da parte aérea foi obtido em outubro $\left(2,731 \mathrm{~kg} \mathrm{~m}^{-2}\right)$, o qual não foi diferente daquele observado em setembro $\left(2,675 \mathrm{~kg} \mathrm{~m}^{-2}\right)$. Essas massas foram diferentes das massas observadas nos meses subseqüentes. A massa observada em novembro $\left(1,688 \mathrm{~kg} \mathrm{~m}^{-2}\right)$ não diferiu das massas de janeiro $\left(1,582 \mathrm{~kg} \mathrm{~m}^{-2}\right)$ e fevereiro $(1,516$ $\mathrm{kg} \mathrm{m}{ }^{-2}$ ), embora tenha sido diferente de dezembro $\left(1,390 \mathrm{~kg} \mathrm{~m}^{-2}\right)$. As massas determinadas em dezembro, janeiro e fevereiro não diferiram entre si (Figura 14).

O comportamento dos valores médios de massa de raízes em comparação com a massa de parte aérea, ambos em relação às alturas de pasto estudadas, foi distinto (Figura 14). Enquanto a massa de raízes manteve um valor relativamente constante, a massa de parte aérea diminuiu com o aumento da altura de pasto. A ausência de diferenças em massa de raízes pode ser justificada, visto que a profundidade utilizada para a coleta das amostras foi de $10 \mathrm{~cm}$. A escolha dessa profundidade, apesar de insuficiente para se determinar a massa total de raízes das plantas forrageiras ou para ratificar uma provável vantagem quantitativa de pastos mantidos mais altos, foi suficiente para se determinar os teores e estoques de compostos de reserva, objetivo principal deste experimento.

Trabalhando com cinco gramíneas forrageiras de clima tropical, entre as quais a braquiária brizanta cv. Marandu, mantidas em pastagens e manejadas através de lotação contínua por três anos, Kanno et al. (1999) relataram que cerca de $60 \%$ do sistema radicular dessas gramíneas encontrava-se nos primeiros $10 \mathrm{~cm}$ de profundidade, independentemente das doses de fertilizantes e corretivos utilizadas. Os valores médios de massa de raízes encontrados por esses autores utilizando 1,5 e 3,0 t ha ${ }^{-1}$ de calcário 
dolomítico associado a 400 e $800 \mathrm{~kg} \mathrm{ha}^{-1}$ de uma fórmula 0-20-20, respectivamente para o menor e o maior grau de uso de corretivos e fertilizantes, foram de 0,734 e 0,881

g $100 \mathrm{~g}^{-1}$ solo seco. A amplitude de valores observada neste experimento foi de 0,507

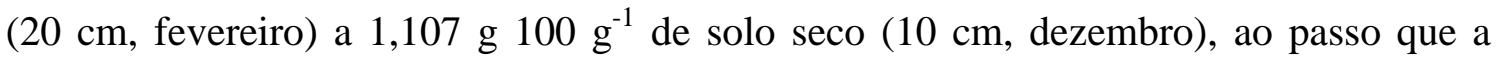

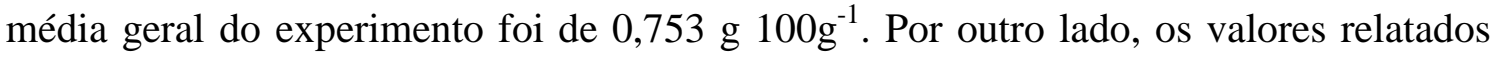
por Soares Filho (1991), para pastagens de braquiária decumbens em processo de degradação e recuperadas, foram sensivelmente menores que aqueles relatados por Kanno et al. (1999) e os obtidos neste experimento, fato que possivelmente poderia estar associado ao método utilizado para a coleta das raízes. A massa de raízes correspondente a cada tratamento no trabalho de Soares Filho (1991) foi obtida através da utilização de um tubo de aço com 1,8 cm de diâmetro e $30 \mathrm{~cm}$ de profundidade, de modo que a análise dos resultados desse experimento ratificou que esse método de amostragem pareceu não ser o mais indicado para gramíneas forrageiras de clima tropical devido, principalmente, à pequena área do cilindro em relação à coroa da planta forrageira, pois aparentemente não representou a condição real da pastagem.

Com relação ao padrão de comportamento observado para a massa da parte aérea, verificou-se que nas menores alturas de pasto estudadas foram obtidas as maiores massas. Esse fato pode ser explicado, considerando-se que os pastos mais baixos (10 e $20 \mathrm{~cm}$ ) apresentaram consistentemente uma maior densidade populacional de perfilhos ao longo do período experimental ${ }^{2}$ e, além disso, uma maior densidade bulk ${ }^{3} \mathrm{em}$ comparação com as maiores alturas de pasto estudadas (30 e $40 \mathrm{~cm}$ ).

É pertinente relatar, todavia, que a escolha das coroas das plantas de braquiária brizanta para a determinação dos teores e estoques de reserva foi mais precisa nas condições de pasto mais baixas do que nas de pastos mais altos, o que pode ter contribuído para o padrão de resposta observado, uma vez que as coroas eram de menor

\footnotetext{
${ }^{2}$ SBRISSIA, A.F. (Escola Superior de Agricultura "Luiz de Queiroz", Piracicaba, SP). Perfilhamento, compensação tamanho/densidade populacional de perfilhos e fluxo de tecidos em pastos de Brachiaria brizantha cv. Marandu. (projeto de doutorado em andamento)

${ }^{3}$ SARMENTO, D.O.L. (Escola Superior de Agricultura “Luiz de Queiroz”, Piracicaba, SP). Comportamento ingestivo de bovinos de corte em pastos de Brachiaria brizantha cv. Marandu (projeto de mestrado em andamento).
} 
tamanho e de ocorrência mais freqüente na área comparativamente a pastos mais altos, sendo, portanto, mais facilmente visualizadas (Figura 15).

$10 \mathrm{~cm}$

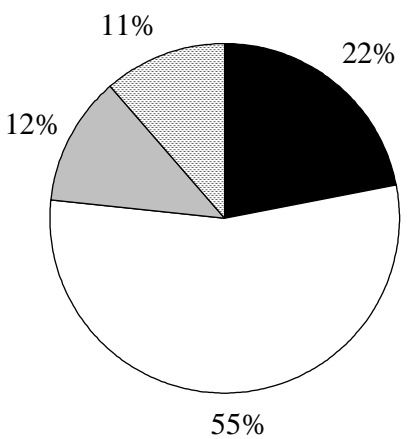

$30 \mathrm{~cm}$

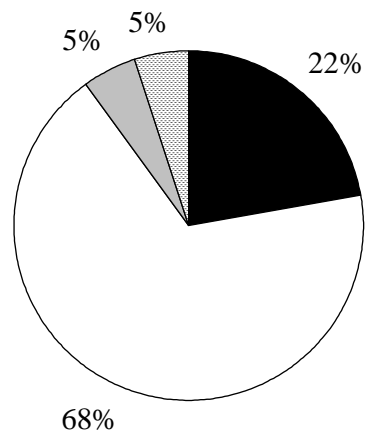

Coroa

Folhas

$\square$ Vazio
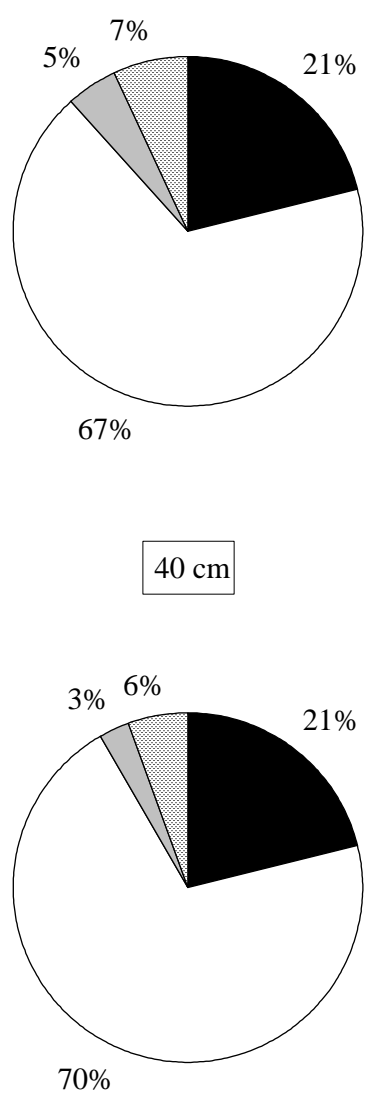

$40 \mathrm{~cm}$

Figura 15 - Distribuição média de plantas de braquiária brizanta (coroa e folhas) mantida em diferentes alturas de pasto durante o período experimental.

Quanto à época de avaliação, foi notório que os meses de setembro e outubro apresentaram as maiores massas tanto de raízes quanto de parte aérea. Esse comportamento pode ser explicado pela ausência de condições climáticas favoráveis 
para o crescimento da planta forrageira. À medida que as condições climáticas passaram a estimular o crescimento das plantas, notou-se uma redução acentuada nas massas dos órgãos de reserva devido a uma provável alteração no direcionamento de fotoassimilados, que preferencialmente foram utilizados para a formação de tecidos fotossintetizantes, conforme relatado por Snyder \& Carlson (1984).

Embora a opção inicial tenha sido expressar os resultados referentes às massas de raízes e de parte aérea em $\mathrm{kg} \mathrm{m}^{-2}$, faz-se oportuno destacar que a extrapolação dos valores dessas massas, bem como dos estoques de reserva correspondentes, para hectare (ha) não seria recomendada devido à limitação do método de amostragem, conforme apresentado em 3.2.6.2. Os resultados de distribuição de plantas de braquiária brizanta nas parcelas evidenciam que a área ocupada por coroas não ultrapassou $25 \%$ em condição alguma de pasto estudada durante o período experimental e, portanto, esse fato não pode ser ignorado no caso de extrapolações (Figura 15).

\subsection{Compostos de reserva}

\subsubsection{Carboidratos não estruturais (CNE)}

\subsubsection{Teores}

Os resultados referentes aos teores de CNE são mostrados nas Tabelas 6 e 7 e nas Figuras 16 e 17. Houve efeito de altura $(\mathrm{P}=0,0004)$, mês $(\mathrm{P}<0,0001)$ e da interação altura x mês $(\mathrm{P}=0,0008)$, os quais são apresentados na Tabela 6 e Figura 16. Houve também efeito de parte da planta $(\mathrm{P}=0,0006)$ e da interação parte da planta x mês $(\mathrm{P}<0,0001)$, que podem ser observados na Tabela 7 e Figura 17. A amplitude dos valores médios dos teores de CNE ao longo do período experimental foi de 40,6 (10 cm, fevereiro) a 139,3 $\mathrm{g} \mathrm{kg}^{-1}$ (20 cm, novembro). $\mathrm{O}$ maior teor de CNE dentre as alturas de pasto estudadas foi obtido em $40 \mathrm{~cm}\left(118,4 \mathrm{~g} \mathrm{~kg}^{-1}\right)$, o qual não diferiu da altura de $20 \mathrm{~cm}\left(111,7 \mathrm{~g} \mathrm{~kg}^{-1}\right)$ que, por sua vez, foi superior às médias de $10\left(88,5 \mathrm{~g} \mathrm{~kg}^{-1}\right)$ e $30 \mathrm{~cm}\left(109,8 \mathrm{~g} \mathrm{~kg}^{-1}\right)$. Os valores para os pastos de $30 \mathrm{~cm}$ foram superiores àqueles dos pastos de $10 \mathrm{~cm}$ (Tabela 6). Com 
relação ao mês, o maior teor médio foi observado em novembro $\left(130,1 \mathrm{~g} \mathrm{~kg}^{-1}\right)$, o qual não diferiu de outubro (120,6 $\mathrm{g} \mathrm{kg}^{-1}$ ) (Tabela 6). O teor relativo a outubro não diferiu daqueles obtidos em setembro (118,8 $\left.\mathrm{g} \mathrm{kg}^{-1}\right)$ e dezembro $\left(115,7 \mathrm{~g} \mathrm{~kg}^{-1}\right)$, os quais foram diferentes dos teores observados em janeiro $\left(70,3 \mathrm{~g} \mathrm{~kg}^{-1}\right)$ e fevereiro $\left(87,2 \mathrm{~g} \mathrm{~kg}^{-1}\right)$, sendo que o teor obtido no mês de janeiro diferiu daquele relativo a fevereiro e foi o menor teor médio de CNE durante todo o período experimental (Figura 17).

Vale ressaltar que os dados referentes ao mês de setembro foram obtidos logo após o corte de uniformização dos pastos e servem, portanto, apenas como referencial inicial de avaliação das variações nos teores de CNE desde o início do estabelecimento das condições de pasto estudadas (Tabela 6).

Os resultados dos teores de CNE relativos às condições de pasto revelaram um padrão de comportamento em que se distingue um grupo homogêneo de teores observados para as alturas de 20,30 e 40 cm, no qual não existem diferenças sob um

Tabela 6. Teores de carboidratos não estruturais $\left(\mathrm{g} \mathrm{kg}^{-1}\right)$ em braquiária brizanta mantida em quatro alturas de pasto, de setembro de 2001 a fevereiro de 2002.

\begin{tabular}{|c|c|c|c|c|c|c|c|c|c|c|c|}
\hline \multirow{2}{*}{ Mês } & \multicolumn{8}{|c|}{ Altura do Pasto (cm) } & \multirow{2}{*}{\multicolumn{2}{|c|}{ Média }} & \multirow{2}{*}{$\mathrm{EPM}^{*}$} \\
\hline & \multicolumn{2}{|c|}{10} & \multicolumn{2}{|c|}{20} & \multicolumn{2}{|l|}{30} & \multicolumn{2}{|l|}{40} & & & \\
\hline Setembro & 120,0 & Aa & 124,5 & $\mathrm{Aa}$ & 112,5 & $\mathrm{ABa}$ & 117,9 & $\mathrm{Aa}$ & 118,8 & B & 4,05 \\
\hline Outubro & 108,7 & $\mathrm{ABb}$ & 129,5 & $\mathrm{Aa}$ & 125,0 & Aab & 119,2 & Aab & 120,6 & $\mathrm{AB}$ & 4,05 \\
\hline Novembro & 116,3 & $\mathrm{Ab}$ & 139,3 & $\mathrm{Aa}$ & 130,6 & Aab & 134,2 & $\mathrm{Aab}$ & 130,1 & A & 4,27 \\
\hline Dezembro & 92,8 & $\mathrm{Bb}$ & 129,1 & $\mathrm{Aa}$ & 115,5 & $\mathrm{Aa}$ & 125,2 & Aa & 115,7 & B & 4,00 \\
\hline Janeiro & 52,8 & $\mathrm{Cb}$ & 50,7 & $\mathrm{Cb}$ & 81,0 & $\mathrm{Ca}$ & 96,7 & $\mathrm{Ba}$ & 70,3 & $\mathrm{D}$ & 4,39 \\
\hline Fevereiro & 40,6 & $\mathrm{Cc}$ & 96,7 & $\mathrm{Bb}$ & 94,5 & $\mathrm{BCb}$ & 117,0 & $\mathrm{ABa}$ & 87,2 & $\mathrm{C}$ & 3,91 \\
\hline Média & 88,5 & c & 111,7 & & 109,8 & $\mathrm{~b}$ & 118,4 & $\mathrm{a}$ & & & \\
\hline $\mathrm{EPM}^{*}$ & 3,02 & & 3,12 & & 3,11 & & 3,02 & & & & \\
\hline
\end{tabular}

*EPM - Erro padrão da média.

Médias na linha seguidas de mesmas letras minúsculas não diferem entre si $(\mathrm{P}>0,10)$.

Médias na coluna seguidas de mesmas letras maiúsculas não diferem entre si $(\mathrm{P}>0,10)$. 
Tabela 7. Teores de carboidratos não estruturais $\left(\mathrm{g} \mathrm{kg}^{-1}\right)$ no sistema radicular (SR) e na parte aérea (PA) de pastos de braquiária brizanta, de setembro de 2001 a fevereiro de 2002.

\begin{tabular}{|c|c|c|c|c|c|c|c|}
\hline Mês & SR & & PA & & Média & & EPM* \\
\hline Setembro & 128,0 & $\mathrm{Ba}$ & 109,6 & $\mathrm{ABb}$ & 118,8 & B & 4,05 \\
\hline Outubro & 144,6 & $\mathrm{Aa}$ & 96,6 & $\mathrm{Bb}$ & 120,6 & $\mathrm{AB}$ & 4,05 \\
\hline Novembro & 155,5 & $\mathrm{Aa}$ & 104,7 & $\mathrm{Bb}$ & 130,1 & A & 4,27 \\
\hline Dezembro & 110,4 & $\mathrm{Ca}$ & 120,9 & $\mathrm{Aa}$ & 115,7 & B & 4,00 \\
\hline Janeiro & 76,5 & $\mathrm{Da}$ & 64,1 & $\mathrm{Ca}$ & 70,3 & D & 4,39 \\
\hline Fevereiro & 70,0 & $\mathrm{Db}$ & 104,3 & $\mathrm{Ba}$ & 87,2 & & 3,91 \\
\hline Média & 114,2 & $\mathrm{a}$ & 100,0 & $b$ & & & \\
\hline EPM* & 2,12 & & 2,22 & & & & \\
\hline
\end{tabular}

*EPM - Erro padrão da média.

Médias na linha seguidas de mesmas letras minúsculas não diferem entre si $(\mathrm{P}>0,10)$.

Médias na coluna seguidas de mesmas letras maiúsculas não diferem entre si $(\mathrm{P}>0,10)$.

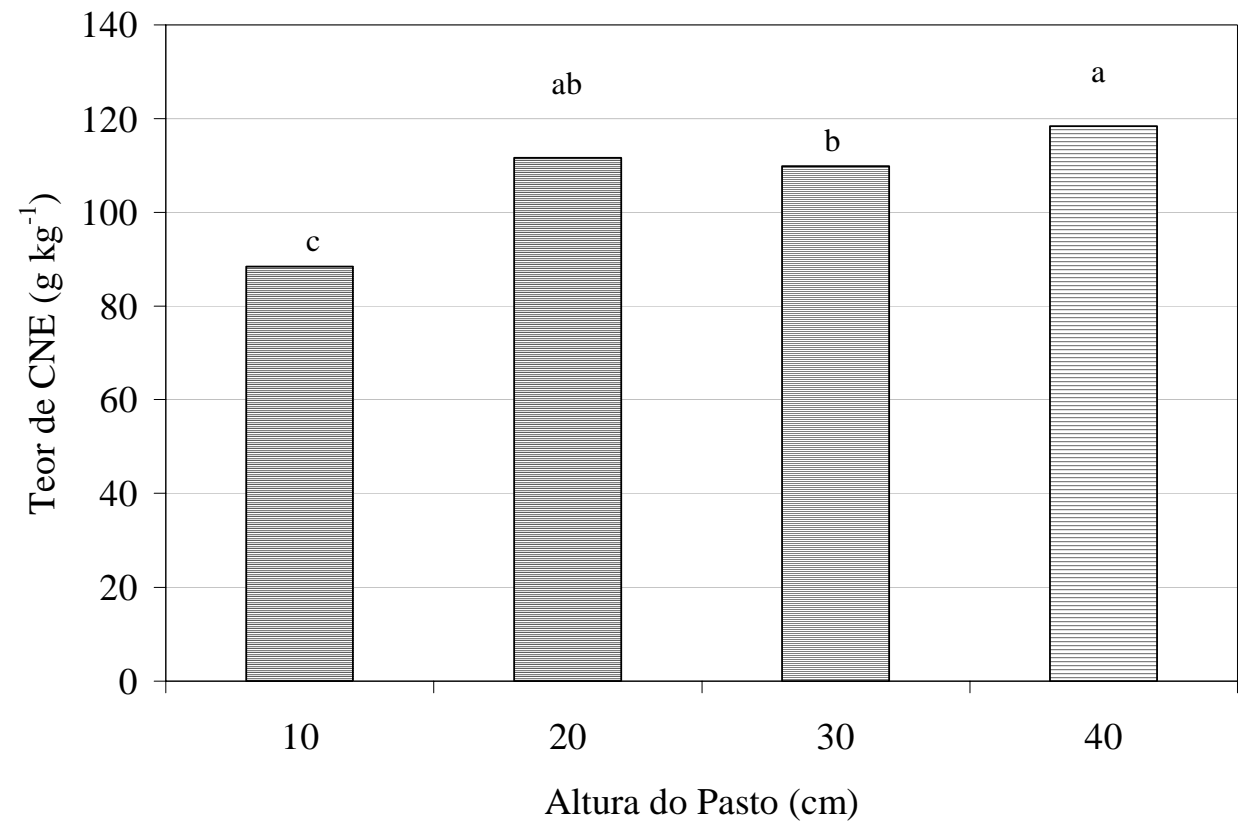

Figura 16 - Teores de CNE em braquiária brizanta mantida em diferentes alturas de pasto. 


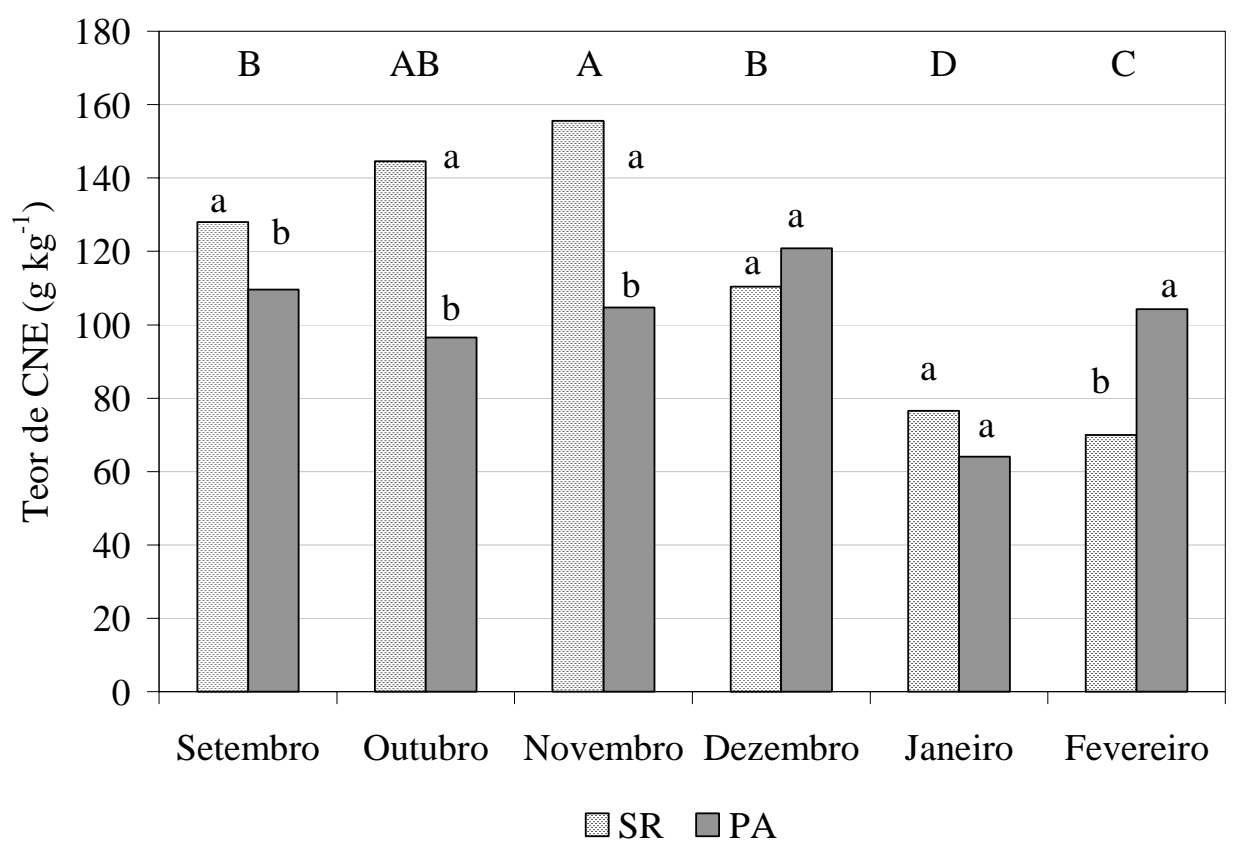

Figura 17 - Teores de carboidratos não estruturais $\left(\mathrm{g} \mathrm{kg}^{-1}\right)$ no sistema radicular (SR) e na parte aérea (PA) de pastos de braquiária brizanta, de setembro de 2001 a fevereiro de 2002.

ponto de vista fisiológico. Estes, por sua vez, diferem daqueles observados para a altura de $10 \mathrm{~cm}$ durante os meses de outubro, novembro e dezembro, quando a planta encontrava-se em estádio vegetativo (Tabela 6). Considerando-se que a altura de pasto de $10 \mathrm{~cm}$ apresentou valores de taxa de acúmulo (Tabela 25) próximos aos observados para os demais tratamentos durante esse período, pode-se inferir que os menores teores de CNE desses pastos em relação às alturas de 20,30 e $40 \mathrm{~cm}$ indicam que a quantidade de assimilados alocados para os tecidos de reserva foi menor, provavelmente como consequência da priorização de produção de tecidos fotossintetizantes. Esse fato pode indicar que a altura de pasto de $10 \mathrm{~cm}$ estaria imprimindo um regime de desfolha drástico o suficiente para colocar a comunidade de plantas da pastagem em uma situação de estresse fisiológico inerente ao seu limite de resistência ao pastejo, objetivo original dessa condição de pasto no planejamento do experimento, ou simplesmente refletindo a maior eficiência de utilização da forragem produzida, consequência de processo 
reduzido de senescência ${ }^{2}$ e correspondente reciclagem interna de nutrientes (Lemaire \& Chapman, 1996).

Já em janeiro e fevereiro, meses em que a planta encontrava-se em estádio reprodutivo (Figura 17), notou-se uma redução acentuada nos teores de CNE em todos os tratamentos, sendo que esse tipo de comportamento já havia sido relatado para plantas forrageiras por Reis et al. (1985), em trabalho realizado com braquiária decumbens. As reduções mais acentuadas foram verificadas para as alturas de 10 e $20 \mathrm{~cm}$, principalmente nos pastos de $20 \mathrm{~cm}$, em janeiro, uma vez que esses vinham apresentando de forma consistente os maiores teores desses compostos desde setembro (Tabela 6). Certamente os pastos mantidos a 10 e $20 \mathrm{~cm}$ foram os mais prejudicados pelo início do florescimento em janeiro, consequência da decapitação de colmos reprodutivos durante uma fase de forte ação como dreno metabólico, não permitindo a manutenção de colmos reprodutivos vivos por muito tempo, o que resultou em concentrações de CNE por volta de 40 a $50 \mathrm{~g} \mathrm{~kg}^{-1}$ (Tabela 6). Gross (1988) indicou teores menores que 20 a $30 \mathrm{~g} \mathrm{~kg}^{-1}$ como limitantes ao desenvolvimento de plantas de braquiária decumbens. Nos pastos de 30 e $40 \mathrm{~cm}$ esse problema foi menor, uma vez que as capacidades de suporte $\left(\mathrm{kg} \mathrm{ha}^{-1}\right.$ de massa corporal) foram sensivelmente reduzidas ${ }^{4}$.

Ainda que os teores de CNE em fevereiro tenham sido diferentes daqueles determinados durante o estádio vegetativo, os valores foram superiores aos de janeiro, fato que, num primeiro momento, poderia parecer contraditório devido à intensificação do florescimento dos pastos nesse mês, mas que, por outro lado, seria justificável devido à redução na taxa de acúmulo de forragem (Tabela 25), motivada principalmente pela redução na precipitação (Tabela 2 e Figura 2). Como consequência, uma maior alocação de fotoassimilados deve ter sido direcionada para tecidos de reserva (sistema radicular e parte aérea), fato também verificado para braquiária decumbens por Reis et al. (1985) e Soares Filho (1991).

\footnotetext{
${ }^{2}$ SBRISSIA, A.F. (Escola Superior de Agricultura "Luiz de Queiroz", Piracicaba, SP). Perfilhamento, compensação tamanho/densidade populacional de perfilhos e fluxo de tecidos em pastos de Brachiaria brizantha cv. Marandu. (projeto de doutorado em andamento)

${ }^{4}$ ANDRADE, F.M.E. (Escola Superior de Agricultura "Luiz de Queiroz", Piracicaba, SP). Valor nutritivo da forragem e desempenho de bovinos de corte em pastos de Brachiaria brizantha cv. Marandu (projeto de mestrado em andamento).
} 
De forma contrária ao que foi observado durante o período de desenvolvimento vegetativo das plantas, no estádio reprodutivo os teores de CNE assumiram um padrão de comportamento crescente em relação às alturas, de modo que os menores teores foram observados nos pastos mantidos em $10 \mathrm{~cm}$ e os maiores nos pastos mantidos em $40 \mathrm{~cm}$ (Tabela 6). Tal fato pode ser compreendido se for considerado que a inflorescência deve ter atuado como o maior dreno metabólico durante a fase reprodutiva (Snyder \& Carlson, 1984) e, portanto, a produção de fotoassimilados não deve ter sido suficientemente grande para assegurar os processos envolvidos com a formação de inflorescências e manutenção dos processos respiratórios e de síntese de tecidos nos pastos de 10 e $20 \mathrm{~cm}$. Como consequência, as plantas precisaram lançar mão dos compostos armazenados nos órgãos de reserva como forma de otimizar a energia proveniente dos fotoassimilados. Desse modo, quanto maior a quantidade de assimilados produzida pela planta, menor deve ter sido a quantidade de reservas mobilizada e utilizada para esse fim. Novamente, a altura de pasto de $10 \mathrm{~cm}$ correspondeu à uma condição de maior estresse para a planta forrageira, condição essa justificada pelos menores teores apresentados durante essa fase de desenvolvimento. Esse padrão de comportamento é típico de regimes de desfolha freqüentes e intensos, nos quais a decapitação de colmos reprodutivos é bastante precoce e resulta em uma condição de balanço negativo de energia em função das alterações na relação fonte:dreno (Snyder \& Carlson, 1984).

Com relação ao órgão de armazenamento dos $\mathrm{CNE}$, foi observado durante o estádio vegetativo que as raízes apresentaram os maiores teores desses compostos (Figura 17). Esses dados confirmam os resultados de Carvalho et al. (2001) para Cynodon spp. durante a fase de desenvolvimento vegetativo que, para essa planta, se estendeu até o início do mês de março. Dessa maneira, se as comparações entre a braquiária brizanta e os cultivares de Cynodon fosse feita com base em época do ano, certamente a conclusão seria que houve diferença em termos da parte da planta que apresentou os maiores teores de CNE. No entanto, se as comparações levarem em consideração o estádio de desenvolvimento da planta forrageira, a conclusão é válida para ambas. 
À medida que a braquiária brizanta passou para o estádio reprodutivo, houve uma inversão na ordem de grandeza dos teores em relação aos órgãos de armazenamento, de modo que em dezembro e janeiro não houve diferença entre raízes e parte aérea e, em fevereiro, os maiores teores de CNE foram observados na parte aérea (Figura 17). Os resultados de Reis et al. (1985) revelaram que a parte aérea foi o órgão que apresentou o maior teor desses compostos. No entanto, os resultados desses autores e de outros, em trabalhos com outras gramíneas forrageiras, foram realizados durante os meses de dezembro a março apenas, época do ano que deve ter contemplado somente plantas em estádio reprodutivo de desenvolvimento.

Nesse contexto, os dados deste experimento corroboram aqueles disponíveis na literatura. No entanto, em função do período experimental contemplar uma fase de desenvolvimento vegetativo, de relação fonte:dreno diferente, ficou claro o padrão distinto de comportamento e partição de fotoassimilados ao longo do ano, revelando o risco potencial que generalizações de dados podem ter sobre a compreensão de processos e o manejo de comunidades de plantas em pastagens.

\subsubsection{Estoques}

Os resultados referentes aos estoques de CNE são mostrados na Tabela 8 e nas Figuras 18 e 19. Houve efeito de mês $(\mathrm{P}<0,0001)$, parte da planta $(\mathrm{P}<0,0001)$ e das interações altura $\mathrm{x}$ mês $(\mathrm{P}<0,0001)$, parte da planta $\mathrm{x}$ mês $(\mathrm{P}<0,0001)$ e altura $\mathrm{x}$ parte da planta $\mathrm{x}$ mês ( $\mathrm{P}=0,00194)$. A amplitude dos valores médios dos estoques de CNE ao longo do período experimental foi de $0,030\left(10 \mathrm{~cm}\right.$, sistema radicular, fevereiro) a $0,354 \mathrm{~kg} \mathrm{~m}^{-2}$ (30 cm, parte aérea, outubro). Com relação ao mês, o maior estoque médio foi observado em outubro $\left(0,238 \mathrm{~kg} \mathrm{~m}^{-2}\right)$, o qual não diferiu de setembro $\left(0,225 \mathrm{~kg} \mathrm{~m}^{-2}\right)$. Os estoques relativos a setembro e outubro diferiram daqueles obtidos em novembro $\left(0,166 \mathrm{~kg} \mathrm{~m}^{-2}\right) \mathrm{e}$ dezembro $\left(0,156 \mathrm{~kg} \mathrm{~m}^{-2}\right)$, os quais foram semelhantes. Os estoques de novembro e dezembro foram diferentes daqueles determinados em janeiro $\left(0,089 \mathrm{~kg} \mathrm{~m}^{-2}\right)$ e fevereiro $\left(0,111 \mathrm{~kg} \mathrm{~m}^{-2}\right)$, sendo que o estoque obtido no mês de janeiro diferiu daquele relativo a 
Tabela 8. Estoques de CNE $\left(\mathrm{kg} \mathrm{m}^{-2}\right)$ no sistema radicular $(\mathrm{SR})$ e na parte aérea $(\mathrm{PA})$ de braquiária brizanta mantida em quatro alturas de pasto, de setembro de 2001 a fevereiro de 2002.

\begin{tabular}{|c|c|c|c|c|c|c|c|c|c|c|}
\hline \multirow{2}{*}{$\begin{array}{l}\text { Altura do } \\
\text { Pasto }\end{array}$} & \multicolumn{6}{|c|}{ Parte da Planta } & \multirow{2}{*}{\multicolumn{3}{|c|}{ Média }} & \multirow{2}{*}{$\begin{array}{l}\text { Média } \\
\text { do Mês }\end{array}$} \\
\hline & \multicolumn{3}{|c|}{ SR } & \multicolumn{3}{|c|}{ PA } & & & & \\
\hline \multicolumn{10}{|c|}{ Setembro - 2001} & \multirow[b]{3}{*}{$0,225^{\mathrm{A}^{\prime}}$} \\
\hline 10 & 0,158 & A & $(0,0262)$ & 0,297 & & $(0,0411)$ & 0,228 & A & $(0,0244)$ & \\
\hline 20 & 0,147 & A & $(0,0300)$ & 0,280 & A & $(0,0152)$ & 0,214 & A & $(0,0168)$ & \\
\hline 30 & 0,146 & A & $(0,0262)$ & 0,325 & A & $(0,0562)$ & 0,235 & A & $(0,0310)$ & \multirow[b]{2}{*}{$(0,0126)$} \\
\hline 40 & 0,177 & A & $(0,0262)$ & 0,271 & A & $(0,0466)$ & 0,224 & A & $(0,0268)$ & \\
\hline \multirow[t]{2}{*}{ Média } & 0,157 & $\mathrm{~b}$ & $(0,0136)$ & 0,293 & & $(0,0213)$ & & & & \\
\hline & \multicolumn{9}{|c|}{ Outubro - 2001} & \multirow{6}{*}{$\begin{array}{l}0,238^{A^{\prime}} \\
(0,0165)\end{array}$} \\
\hline 10 & 0,128 & B & $(0,022)$ & 0,284 & & $(0,0650)$ & 0,206 & A & $(0,0343)$ & \\
\hline 20 & 0,174 & $\mathrm{AB}$ & $(0,027)$ & 0,334 & A & $(0,0598)$ & 0,254 & A & $(0,0327)$ & \\
\hline 30 & 0,191 & A & $(0,022)$ & 0,354 & A & $(0,0674)$ & 0,272 & A & $(0,0354)$ & \\
\hline 40 & 0,150 & $\mathrm{AB}$ & $(0,022)$ & 0,291 & A & $(0,0546)$ & 0,220 & A & $(0,0294)$ & \\
\hline \multirow[t]{2}{*}{ Média } & 0,161 & $\mathrm{~b}$ & $(0,0116)$ & 0,316 & & $(0,0309)$ & & & & \\
\hline & \multicolumn{9}{|c|}{ Novembro - 2001} & \multirow{6}{*}{$\begin{array}{l}0,166^{\mathrm{B}^{\prime}} \\
(0,0084)\end{array}$} \\
\hline 10 & 0,120 & A & $(0,0206)$ & 0,198 & B & $(0,0208)$ & 0,159 & B & $(0,0146)$ & \\
\hline 20 & 0,150 & A & $(0,0212)$ & 0,173 & $\mathrm{BC}$ & $(0,0268)$ & 0,161 & B & $(0,0171)$ & \\
\hline 30 & 0,135 & A & $(0,0206)$ & 0,312 & A & $(0,0338)$ & 0,223 & A & $(0,0198)$ & \\
\hline 40 & 0,112 & A & $(0,0206)$ & 0,127 & $\mathrm{C}$ & $(0,0234)$ & 0,119 & $\mathrm{C}$ & $(0,0156)$ & \\
\hline \multirow[t]{2}{*}{ Média } & 0,129 & $\mathrm{~b}$ & $(0,0104)$ & 0,202 & & $(0,0133)$ & & & & \\
\hline & \multicolumn{9}{|c|}{ Dezembro - 2001} & \multirow{6}{*}{$\begin{array}{l}0,156^{\mathrm{B}^{\prime}} \\
(0,0081)\end{array}$} \\
\hline 10 & 0,146 & $\mathrm{AB}$ & $(0,0210)$ & 0,210 & & $(0,0244)$ & 0,178 & A & $(0,0$ & \\
\hline 20 & 0,177 & A & $(0,0208)$ & 0,163 & $\mathrm{AB}$ & $(0,0258)$ & 0,170 & A & $(0,0166)$ & \\
\hline 30 & 0,117 & $\mathrm{BC}$ & $(0,0210)$ & 0,190 & $\mathrm{AB}$ & $(0,0244)$ & 0,153 & $\mathrm{AB}$ & $(0,0161)$ & \\
\hline 40 & 0,094 & $\mathrm{C}$ & $(0,0210)$ & 0,148 & B & $(0,0232)$ & 0,121 & B & $(0,0157)$ & \\
\hline \multirow[t]{2}{*}{ Média } & 0,133 & $\mathrm{~b}$ & $(0,0105)$ & 0,178 & $\mathrm{a}$ & $(0,0123)$ & & & & \\
\hline & \multicolumn{9}{|c|}{ Janeiro - 2002} & \multirow{7}{*}{$\begin{array}{l}0,089^{\mathrm{D}} \\
(0,0064)\end{array}$} \\
\hline 10 & 0,087 & $\mathrm{AB}$ & $(0,0165)$ & 0,083 & A & $(0,0174)$ & 0,085 & $\mathrm{AB}$ & 20) & \\
\hline 20 & 0,054 & B & $(0,0184)$ & 0,076 & A & $(0,0194)$ & 0,065 & B & $(0,0134)$ & \\
\hline 30 & 0,074 & $\mathrm{AB}$ & $(0,0165)$ & 0,114 & A & $(0,0210)$ & 0,094 & $\mathrm{AB}$ & $(0,0134)$ & \\
\hline 40 & 0,105 & A & $(0,0165)$ & 0,119 & A & $(0,0186)$ & 0,112 & A & $(0,0124)$ & \\
\hline \multirow[t]{2}{*}{ Média } & 0,080 & $\mathrm{a}$ & $(0,0085)$ & 0,098 & $\mathrm{a}$ & $(0,0096)$ & & & & \\
\hline & & & & Feve & & -2002 & & & & \\
\hline 10 & 0,030 & B & $(0,0113)$ & 0,081 & $\mathrm{C}$ & $(0,0195)$ & 0,056 & $\mathrm{C}$ & & \multirow{5}{*}{$\begin{array}{l}0,111^{C^{\prime}} \\
(0,0057)\end{array}$} \\
\hline 20 & 0,046 & $\mathrm{AB}$ & $(0,0131)$ & 0,227 & A & $(0,0197)$ & 0,137 & A & $(0,0118)$ & \\
\hline 30 & 0,056 & $\mathrm{AB}$ & $(0,0112)$ & 0,151 & B & $(0,0191)$ & 0,104 & B & $(0,0111)$ & \\
\hline 40 & 0,074 & A & $(0,0113)$ & 0,220 & A & $(0,0189)$ & 0,147 & A & $(0,0110)$ & \\
\hline Média & 0,051 & $\mathrm{~b}$ & $(0,0059)$ & 0,170 & $\mathrm{a}$ & $(0,0097)$ & & & & \\
\hline
\end{tabular}

Valores entre parênteses indicam o Erro Padrão da Média (EPM).

Médias na linha seguidas de mesmas letras minúsculas não diferem entre si $(\mathrm{P}>0,10)$.

Médias na coluna seguidas de mesmas letras maiúsculas não diferem entre si $(\mathrm{P}>0,10)$. 


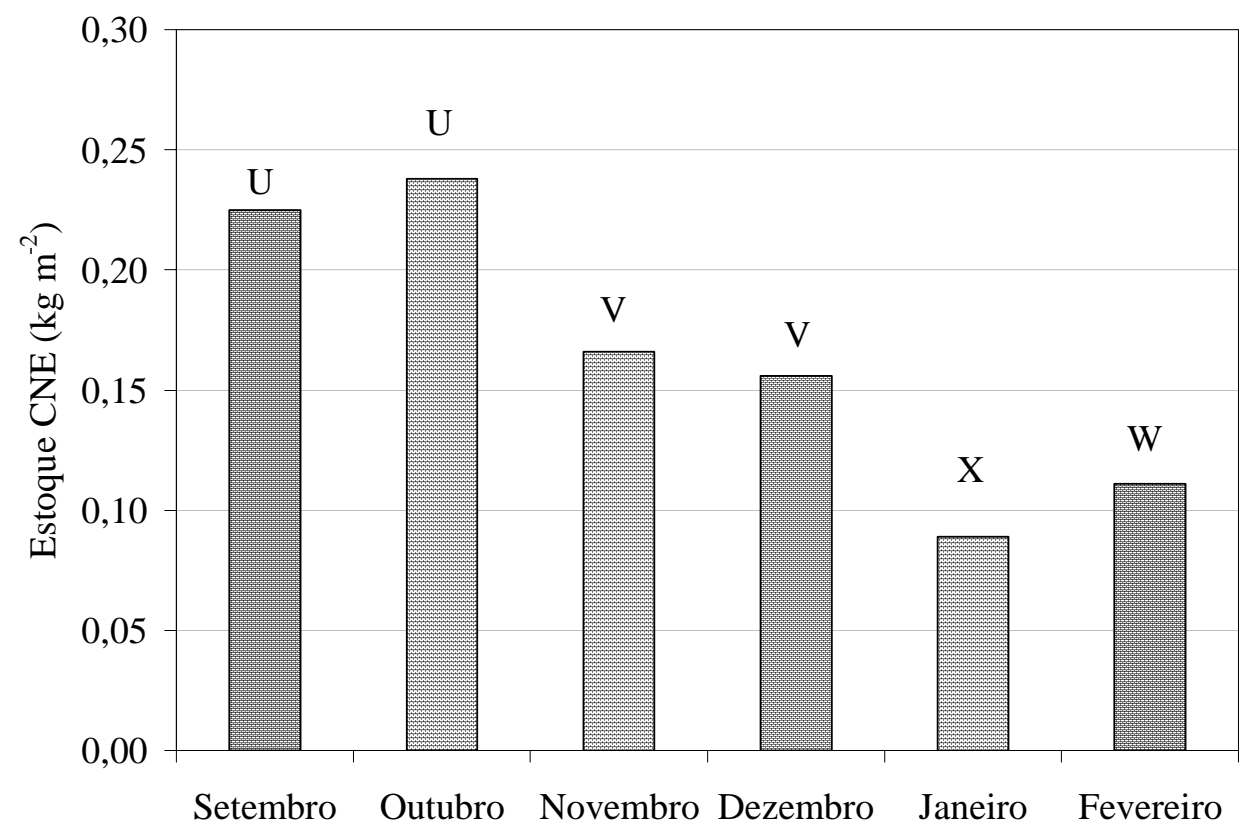

Figura 18 - Estoques de carboidratos não estruturais $\left(\mathrm{kg} \mathrm{m}^{-2}\right)$ em pastos de braquiária brizanta, de setembro de 2001 a fevereiro de 2002.

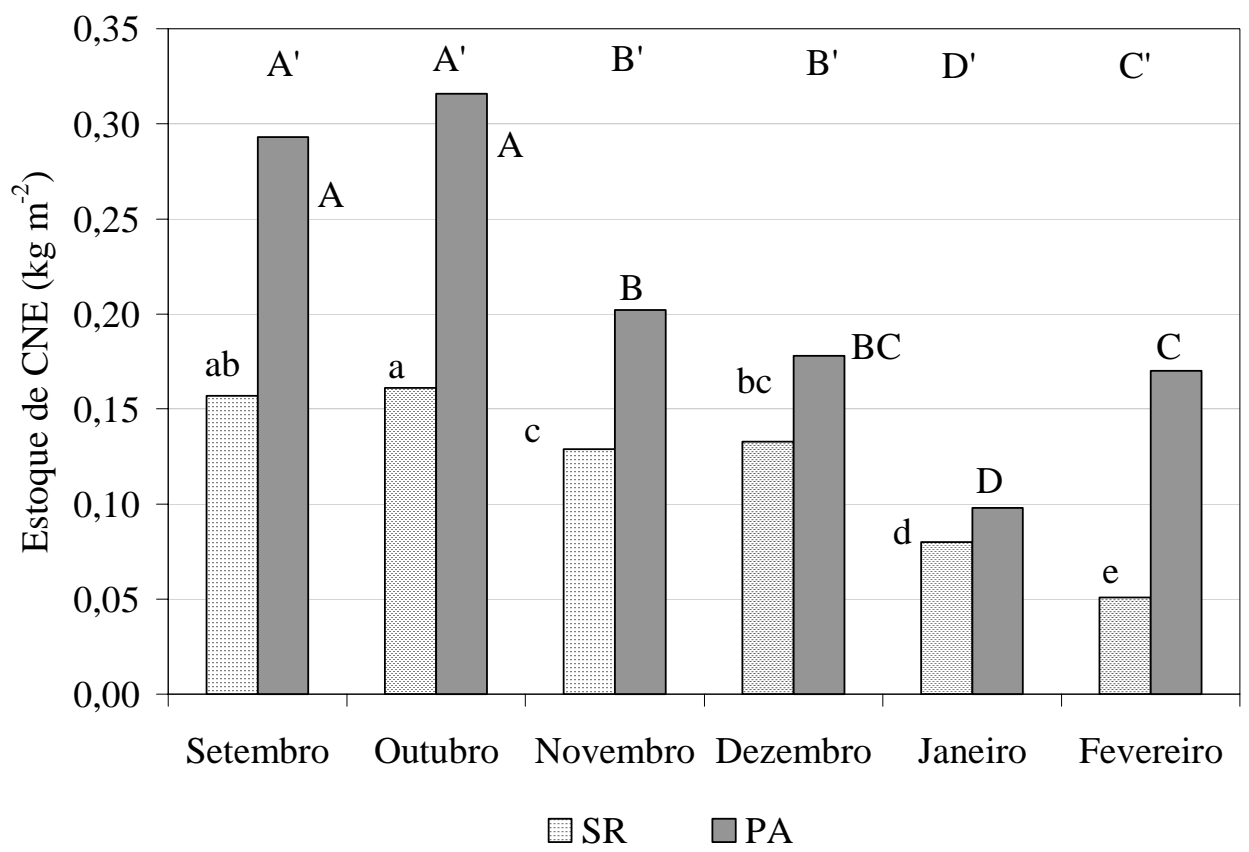

Figura 19 - Estoques de carboidratos não estruturais no sistema radicular (SR) e na parte aérea (PA) de pastos de braquiária brizanta, de setembro de 2001 a fevereiro de 2002. 
a fevereiro e foi o menor estoque médio de CNE durante todo o período experimental (Figura 18).

O padrão de comportamento dos estoques de CNE ao longo do período experimental foi semelhante ao descrito para os teores desses compostos (Figura 17), sendo que somente em novembro foi observada uma diferença significativa no comportamento desses parâmetros. Nesse mês, a planta encontrava-se em estádio vegetativo e, portanto, a redução nos estoques de CNE foi provavelmente decorrente da menor massa dos órgãos de reserva (Figura 14), provavelmente como consequência do aumento da taxa de acúmulo de forragem em virtude de condições climáticas favoráveis, consequência da priorização da produção de tecidos fotossintetizantes. Assim, considerando-se que o padrão de comportamento dos estoques de CNE foi semelhante àquele observado para os teores desses compostos, pode-se inferir que os fatores que atuaram na determinação do padrão de comportamento dos teores foram semelhantes àqueles relativos ao comportamento dos estoques de CNE.

Adicionalmente, a redução dos estoques de CNE foi superior na parte aérea em relação ao sistema radicular (Figura 19), chegando a atingir 49,38\% e 63,70\% em dezembro e fevereiro, respectivamente, em relação aos maiores estoques observados durante o período experimental. Esse comportamento pode ser justificado pela maior proximidade da parte aérea aos principais drenos da planta (Snyder \& Carlson, 1984).

Com relação ao órgão de armazenamento dos CNE, foi notado que a parte aérea apresentou consistentemente os maiores estoques desses compostos em relação ao sistema radicular ao longo do período experimental (Figura 19), o que foi devido fundamentalmente à maior massa da parte aérea em comparação ao sistema radicular (Figura 14), que mesmo apresentando os maiores teores desses compostos nos meses de setembro, outubro, novembro e janeiro (Tabela 7 e Figura 17), revelou consistentemente os menores estoques de CNE (Tabela 8 e Figura 19). 


\subsubsection{Compostos Nitrogenados}

\subsubsection{Nitrogênio total ( $N$ total)}

\subsection{Teores}

Os resultados referentes aos teores de $\mathrm{N}$ total são mostrados nas Tabelas 9 e 10 e nas Figuras 20 e 21. Houve efeito de altura $(\mathrm{P}=0,0012)$, mês $(\mathrm{P}<0,0001)$ e da interação parte da planta x mês $(\mathrm{P}=0,0004)$, embora não tenha sido observado efeito de parte da planta $(\mathrm{P}=0,2658)$. A amplitude dos valores médios dos teores de $\mathrm{N}$ total ao longo do período experimental foi de 3,48 (40 cm, fevereiro) a $14,80 \mathrm{~g} \mathrm{~kg}^{-1}$ (10 cm, setembro) (Tabela 9). O maior teor médio de $\mathrm{N}$ total dentre as alturas de pasto estudadas foi alcançado em $10 \mathrm{~cm}\left(10,65 \mathrm{~g} \mathrm{~kg}^{-1}\right)$, o qual diferiu das demais alturas. O teor médio de $\mathrm{N}$ total na altura de pasto de $20 \mathrm{~cm}\left(8,93 \mathrm{~g} \mathrm{~kg}^{-1}\right)$ foi semelhante àquele determinado para $\mathrm{a}$ altura de $30 \mathrm{~cm}\left(8,64 \mathrm{~g} \mathrm{~kg}^{-1}\right)$, embora diferente daquele relativo a altura de $40 \mathrm{~cm}(8,04 \mathrm{~g}$ $\mathrm{kg}^{-1}$ ) (Tabela 9 e Figura 20). Os teores médios das alturas de pasto de 30 e $40 \mathrm{~cm}$ foram semelhantes. Com relação ao mês, o maior teor médio de $\mathrm{N}$ total foi obtido em setembro $\left(12,76 \mathrm{~g} \mathrm{~kg}^{-1}\right)$, ao passo que o menor ocorreu no mês de fevereiro $\left(3,98 \mathrm{~g} \mathrm{~kg}^{-1}\right)$. Os teores médios de $\mathrm{N}$ total relativos aos meses de setembro a fevereiro foram diferentes entre si e decresceram ao longo do tempo (Figura 21).

$\mathrm{O}$ padrão de comportamento dos teores médios de $\mathrm{N}$ total correspondente às alturas de pasto estudadas foi decrescente, atingindo o maior e o menor teor nas alturas de pasto de 10 e $40 \mathrm{~cm}$, respectivamente (Figura 20). Esse comportamento poderia ser justificado por uma maior taxa de renovação de tecidos, resultado de altas taxas de aparecimento e morte de perfilhos ${ }^{2}$ associadas a uma maior frequência de desfolha de perfilhos individuais ${ }^{5}$ na altura de pasto de $10 \mathrm{~cm}$, os quais sendo mais jovens e desenvolvendo-se num ambiente com menor competição por luz, apresentaram atividade

\footnotetext{
${ }^{2}$ SBRISSIA, A.F. (Escola Superior de Agricultura "Luiz de Queiroz”, Piracicaba, SP). Perfilhamento, compensação tamanho/densidade populacional de perfilhos e fluxo de tecidos em pastos de Brachiaria brizantha cv. Marandu. (projeto de doutorado em andamento)

${ }^{5}$ GONÇALVES, A.C. (Escola Superior de Agricultura "Luiz de Queiroz", Piracicaba, SP). Morfogênese, intensidade e frequência de desfolha em pastos de Brachiaria brizantha cv. Marandu. (Dissertação de mestrado em elaboração)
} 
Tabela 9. Teores de nitrogênio total $\left(\mathrm{g} \mathrm{kg}^{-1}\right)$ de braquiária brizanta mantida em quatro alturas de pasto, de setembro de 2001 a fevereiro de 2002.

\begin{tabular}{|c|c|c|c|c|c|c|c|}
\hline \multirow{2}{*}{ Mês } & \multicolumn{4}{|c|}{ Altura do Pasto (cm) } & \multirow{2}{*}{\multicolumn{2}{|c|}{ Média }} & \multirow{2}{*}{ EPM* } \\
\hline & 10 & 20 & 30 & 40 & & & \\
\hline Setembro & 14,80 & 12,35 & 11,82 & 12,08 & 12,76 & A & 0,353 \\
\hline Outubro & 12,96 & 11,96 & 11,03 & 10,28 & 11,56 & B & 0,332 \\
\hline Novembro & 11,99 & 9,89 & 10,21 & 10,53 & 10,65 & C & 0,332 \\
\hline Dezembro & 11,50 & 8,85 & 8,86 & 6,94 & 8,95 & D & 0,332 \\
\hline Janeiro & 7,71 & 6,86 & 6,40 & 4,96 & 6,49 & E & 0,331 \\
\hline Fevereiro & 5,26 & 3,66 & 3,53 & 3,48 & 3,98 & $\mathrm{~F}$ & 0,333 \\
\hline Média & $10,65^{a}$ & $8,93^{b}$ & $8,64^{b c}$ & $8,04^{\mathrm{c}}$ & & & \\
\hline $\mathrm{EPM}^{*}$ & 0,306 & 0,306 & 0,315 & 0,306 & & & \\
\hline
\end{tabular}

*EPM - Erro padrão da média.

Médias na linha seguidas de mesmas letras minúsculas não diferem entre si $(\mathrm{P}>0,10)$.

Médias na coluna seguidas de mesmas letras maiúsculas não diferem entre si $(P>0,10)$.

Tabela 10. Teores de nitrogênio total $\left(\mathrm{g} \mathrm{kg}^{-1}\right)$ no sistema radicular (SR) e na parte aérea (PA) de pastos de braquiária brizanta, de setembro de 2001 a fevereiro de 2002 .

\begin{tabular}{lrrrrr}
\hline \multicolumn{1}{c}{ Mês } & SR & PA & Média & EPM* $^{*}$ \\
\hline Setembro & $12,54^{\text {A }}$ & $12,99^{\text {A }}$ & $12,76^{\text {A }}$ & 0,353 \\
Outubro & $10,70^{\text {B }}$ & $12,42^{\text {A }}$ & $11,56^{\text {B }}$ & 0,332 \\
Novembro & $10,68^{\text {B }}$ & $10,63^{\text {B }}$ & $10,65^{\text {C }}$ & 0,332 \\
Dezembro & $9,18^{\text {C }}$ & $8,72^{\text {C }}$ & $8,95^{\text {D }}$ & 0,332 \\
Janeiro & $6,73^{\text {D }}$ & $6,24^{\text {D }}$ & $6,49^{\text {E }}$ & 0,331 \\
Fevereiro & $4,00^{\text {E }}$ & $3,96^{\text {E }}$ & $3,98^{\text {F }}$ & 0,333 \\
Média & 8,97 & $9,16^{*}$ & & & \\
EPM & 0,173 & $0,175^{*}$ & & & \\
\hline
\end{tabular}

*EPM - Erro padrão da média.

Médias na coluna seguidas de mesmas letras maiúsculas não diferem entre si $(P>0,10)$. 


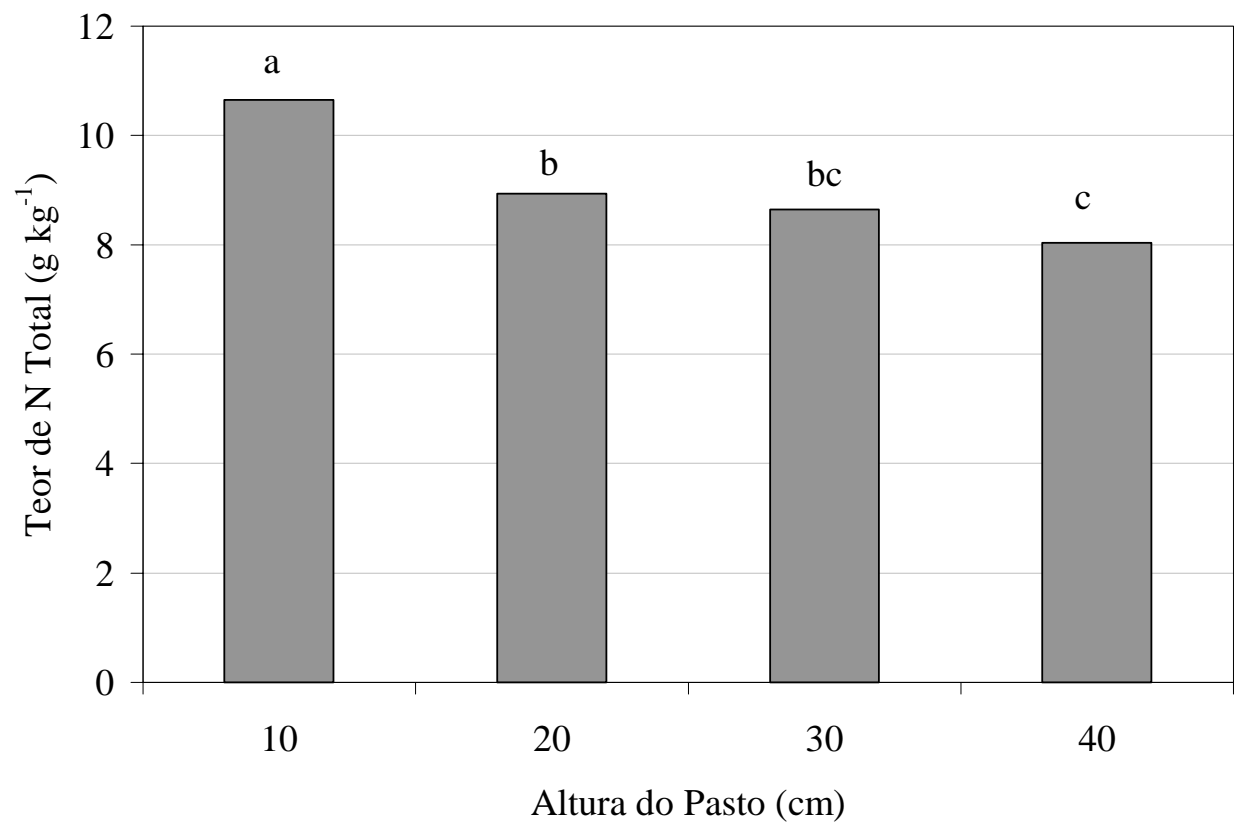

Figura 20 - Teores de $\mathrm{N}$ total em braquiária brizanta mantida em diferentes alturas de pasto.

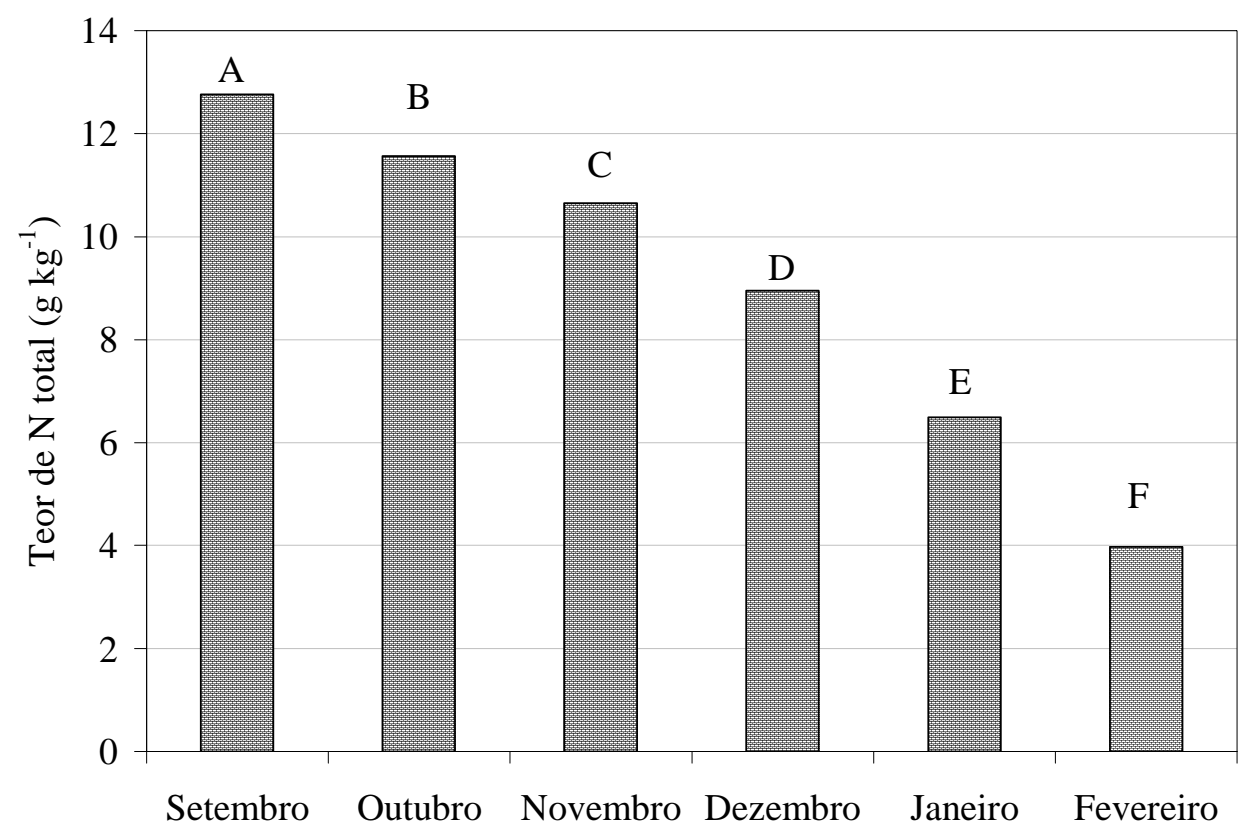

Figura 21 - Teores de $\mathrm{N}$ total em pastos de braquiária brizanta, de setembro de 2001 a fevereiro de 2002. 
metabólica mais intensa em comparação com os pastos mantidos mais altos. Por outro lado, os pastos mantidos mais altos $(20,30$ e $40 \mathrm{~cm})$ deveriam apresentar uma estrutura basal mais rígida, necessária para a sustentação do dossel, de modo que a rigidez dessa estrutura seria proporcional ao tamanho da parte aérea das plantas (McMahon, 1973). A análise da relação C:N dos órgãos de reserva, assumindo-se uma concentração média de 44\% de carbono nos CNE (Parsons \& Chapman, 2000), ratificou essas hipóteses, mostrando que a medida que a altura de pasto aumentou, tal relação também aumentou (Figura 18), tendo como consequência direta um menor teor de $\mathrm{N}$ total. No entanto, essa justificativa seria válida somente se a planta não acumulasse frações nitrogenadas durante os períodos favoráveis ao crescimento vegetativo, o que não foi observado no experimento, ou, por outro lado, se a taxa de mobilização de $\mathrm{N}$ total fosse superior à sua taxa de armazenamento. Essa segunda hipótese poderia ser descartada visto que as taxas de renovação de tecidos foram superiores nos pastos mais baixos e, portanto, segundo a mesma, deveriam apresentar os menores teores de $\mathrm{N}$ total, fato que não aconteceu (Figura 20).

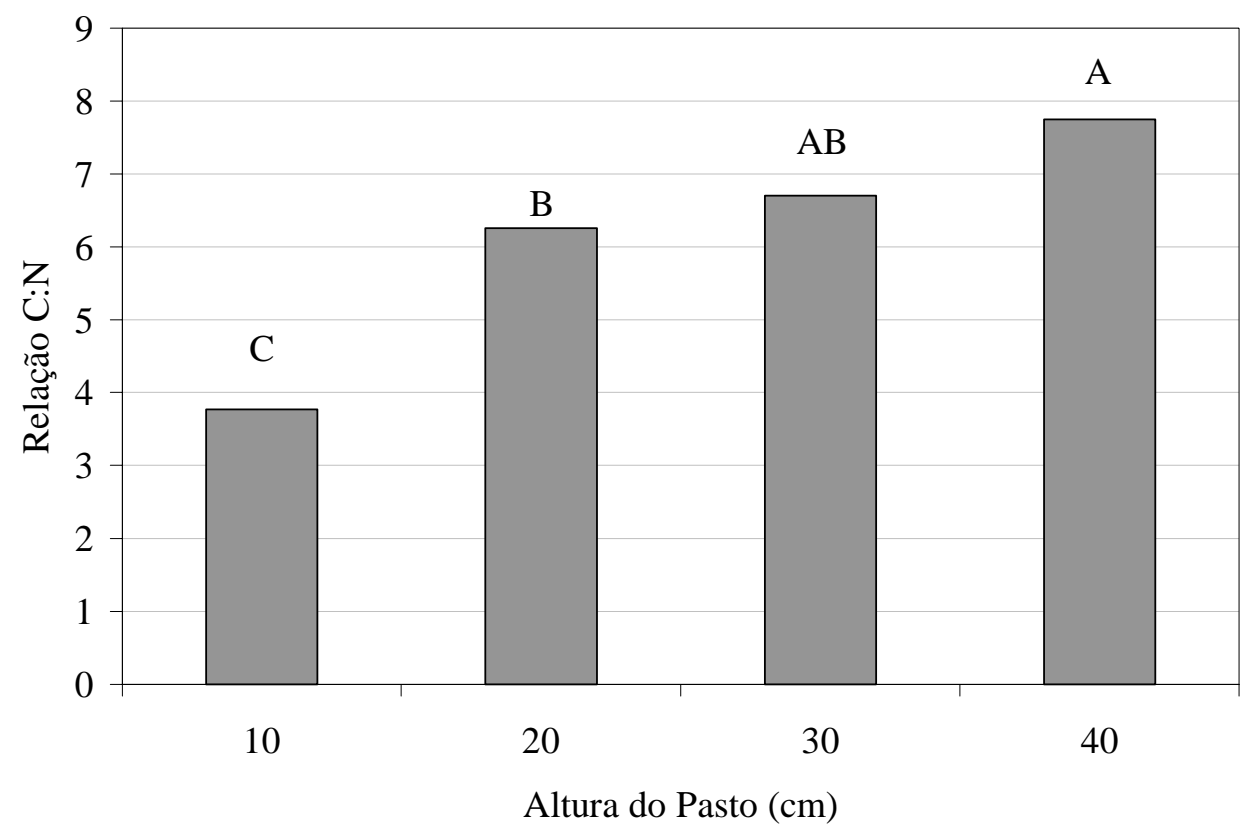

Figura 22 - Relação C:N em braquiária brizanta mantida em diferentes alturas de pasto. 
Com relação ao mês, os teores de $\mathrm{N}$ total foram decrescentes ao longo do período experimental, tanto durante o estádio de desenvolvimento vegetativo quanto durante a fase reprodutiva (Tabela 9). Esse padrão de comportamento poderia ser explicado novamente pelo crescimento das plantas (Volenec et al., 1996; Lemaire \& Gastal, 1997). Durante o período de crescimento mais pronunciado da planta forrageira (novembro a janeiro), observou-se a utilização do nitrogênio sem que houvesse qualquer investimento em acúmulo de reservas nitrogenadas por parte da planta. Em seguida, com o início do estádio reprodutivo, quando as inflorescências passaram a ser os principais drenos da planta, novamente não houve acúmulo de reservas nitrogenadas. Além disso, em se tratando de tecidos vegetais, é pertinente considerar que os teores de $\mathrm{N}$ total tendem a diminuir progressivamente na medida em que a planta atinge estádios de desenvolvimento mais avançados (Mengel \& Kirkby, 2001).

$\mathrm{O}$ padrão de comportamento dos teores de $\mathrm{N}$ total observado neste trabalho corrobora aqueles mostrados por Soares Filho (1991) e Volenec et al. (1996) para braquiária decumbens e alfafa, respectivamente, de modo que poderia ser assumido que os teores de $\mathrm{N}$ total descrevem, ao longo do ano, um padrão estacional, caracterizado por redução acentuada desses teores durante as épocas de primavera e verão, compensada, provavelmente, por elevação durante o período de outono/inverno.

\subsection{Estoques}

Os resultados referentes aos estoques de $\mathrm{N}$ total são mostrados na Tabela $11 \mathrm{e}$ nas Figuras 23 e 24. Houve efeito de altura $(\mathrm{P}=0,0018)$, mês $(\mathrm{P}<0,0001)$, parte da planta $(\mathrm{P}<0,0001)$ e das interações altura $\mathrm{x}$ mês $(\mathrm{P}<0,0001)$, altura $\mathrm{x}$ parte da planta $(\mathrm{P}=0,0191)$, parte da planta $\mathrm{x}$ mês $(\mathrm{P}<0,0001)$ e altura $\mathrm{x}$ parte da planta $\mathrm{x}$ mês $(\mathrm{P}<0,0001)$. A amplitude dos valores médios dos estoques de $\mathrm{N}$ total durante o período experimental foi de $0,003\left(10,20\right.$ e $40 \mathrm{~cm}$, sistema radicular, fevereiro) a 0,054 $\mathrm{kg} \mathrm{m}^{-2}$ (20 cm, parte aérea, setembro) (Tabela 11). A altura de pasto de $10 \mathrm{~cm}\left(0,036 \mathrm{~kg} \mathrm{~m}^{-2}\right)$ apresentou o maior valor médio de estoque ao longo do período experimental, o qual não 
diferiu da altura de pasto de $20 \mathrm{~cm}\left(0,035 \mathrm{~kg} \mathrm{~m}^{-2}\right)$ que, por sua vez, foi distinto dos valores determinados para as alturas de $30\left(0,029 \mathrm{~kg} \mathrm{~m}^{-2}\right)$ e $40 \mathrm{~cm}\left(0,024 \mathrm{~kg} \mathrm{~m}^{-2}\right)$ (Figura 23). Os estoques relativos às alturas de pasto de 20,30 e $40 \mathrm{~cm}$ diferiram entre si. Com relação ao mês, assim como foi observado para os teores de $\mathrm{N}$ total, houve uma redução acentuada nos estoques de $\mathrm{N}$ total ao longo do período experimental. $\mathrm{O}$ maior valor médio de estoque de $\mathrm{N}$ total foi encontrado no mês de setembro $\left(0,031 \mathrm{~kg} \mathrm{~m}^{-2}\right)$, ao passo que o menor valor foi observado no mês de fevereiro $\left(0,005 \mathrm{~kg} \mathrm{~m}^{-2}\right)$ (Figura 24). À exceção dos valores médios relativos aos meses de novembro $\left(0,014 \mathrm{~kg} \mathrm{~m}^{-2}\right)$ e dezembro $\left(0,012 \mathrm{~kg} \mathrm{~m}^{-2}\right)$, cujos estoques foram semelhantes entre si, todos os outros valores foram distintos. No que diz respeito à parte da planta, os maiores valores de estoques de $\mathrm{N}$ total foram consistentemente encontrados na parte aérea (Figura 24). O valor médio da parte aérea durante o período experimental $\left(0,021 \mathrm{~kg} \mathrm{~m}^{-2}\right)$ foi diferente daquele obtido para o sistema radicular $\left(0,009 \mathrm{~kg} \mathrm{~m}^{-2}\right)$.

$\mathrm{O}$ padrão de comportamento dos estoques de $\mathrm{N}$ total em relação às alturas de pasto estudadas foi decrescente (Figura 23), como consequência dos padrões de comportamento relatados para as massas dos órgãos de reserva e para os teores de $\mathrm{N}$ total. A provável explicação para essa redução nos estoques de $\mathrm{N}$ total é semelhante àquela apresentada para os teores desses compostos, isto é, houve uma menor taxa de renovação de tecidos na medida em que a altura de pasto aumentou, fato corroborado pela concomitante elevação da relação C:N nas alturas de pasto mais altas (Figura 22).

Quanto ao mês, o padrão de comportamento dos estoques de $\mathrm{N}$ total revelou-se semelhante aquele descrito para os teores desses compostos, o que poderia estar associado a um padrão estacional de acúmulo de reservas nitrogenadas, segundo o qual, durante o período favorável ao crescimento da planta forrageira e também durante parte de seu desenvolvimento reprodutivo, seria observada uma redução nesses estoques, ao passo que, em épocas desfavoráveis ao crescimento da planta, principalmente determinadas por restrições climáticas, tanto os teores quanto os estoques desses compostos voltariam a aumentar. 
Tabela 11. Estoques de $\mathrm{N}$ total $\left(\mathrm{kg} \mathrm{m}^{-2}\right)$ no sistema radicular (SR) e na parte aérea (PA) de braquiária brizanta mantida em quatro alturas de pasto, de setembro de 2001 a fevereiro de 2002.

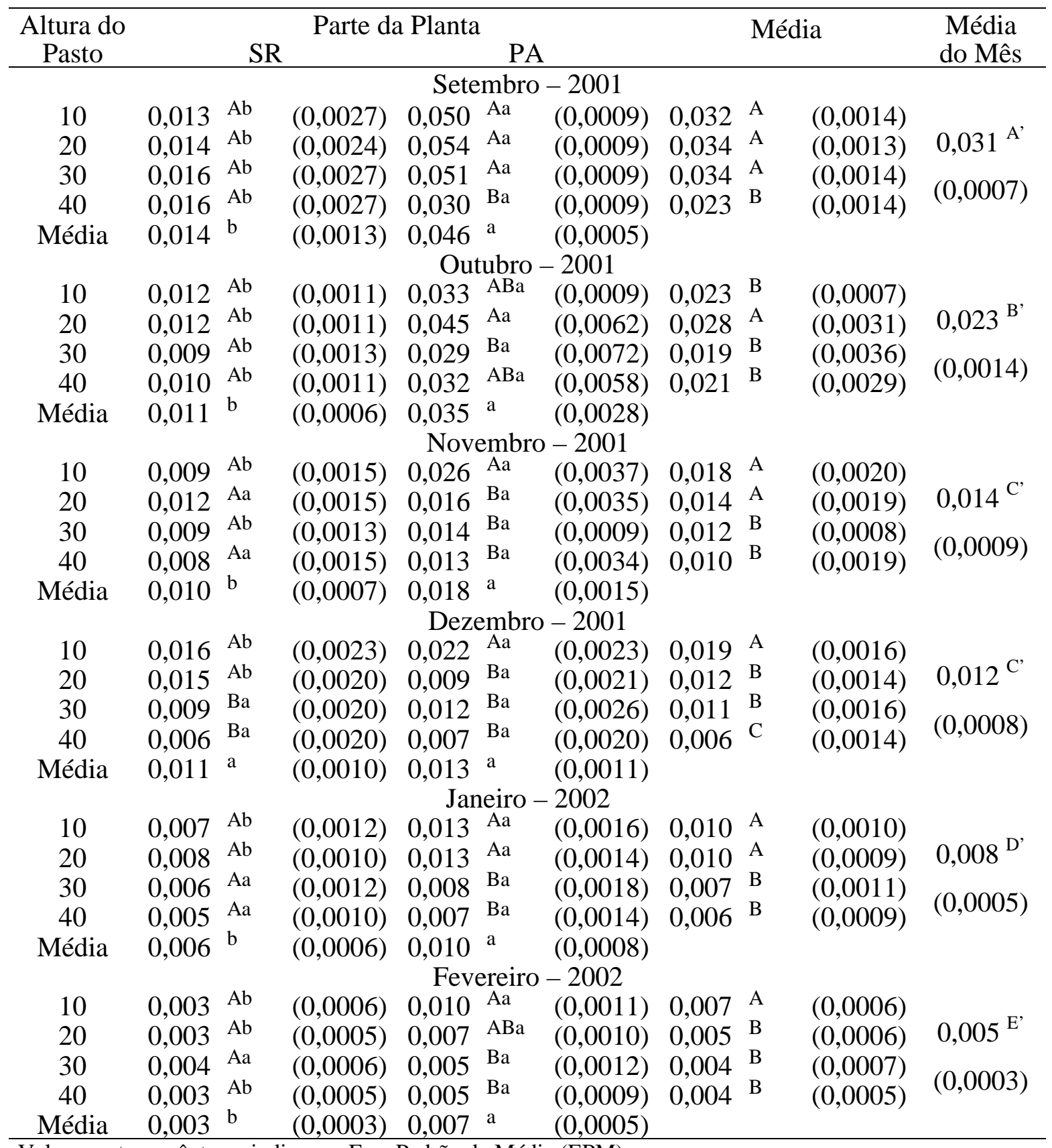

Valores entre parênteses indicam o Erro Padrão da Média (EPM).

Médias na linha seguidas de mesmas letras minúsculas não diferem entre si $(\mathrm{P}>0,10)$.

Médias na coluna seguidas de mesmas letras maiúsculas não diferem entre si $(\mathrm{P}>0,10)$. 


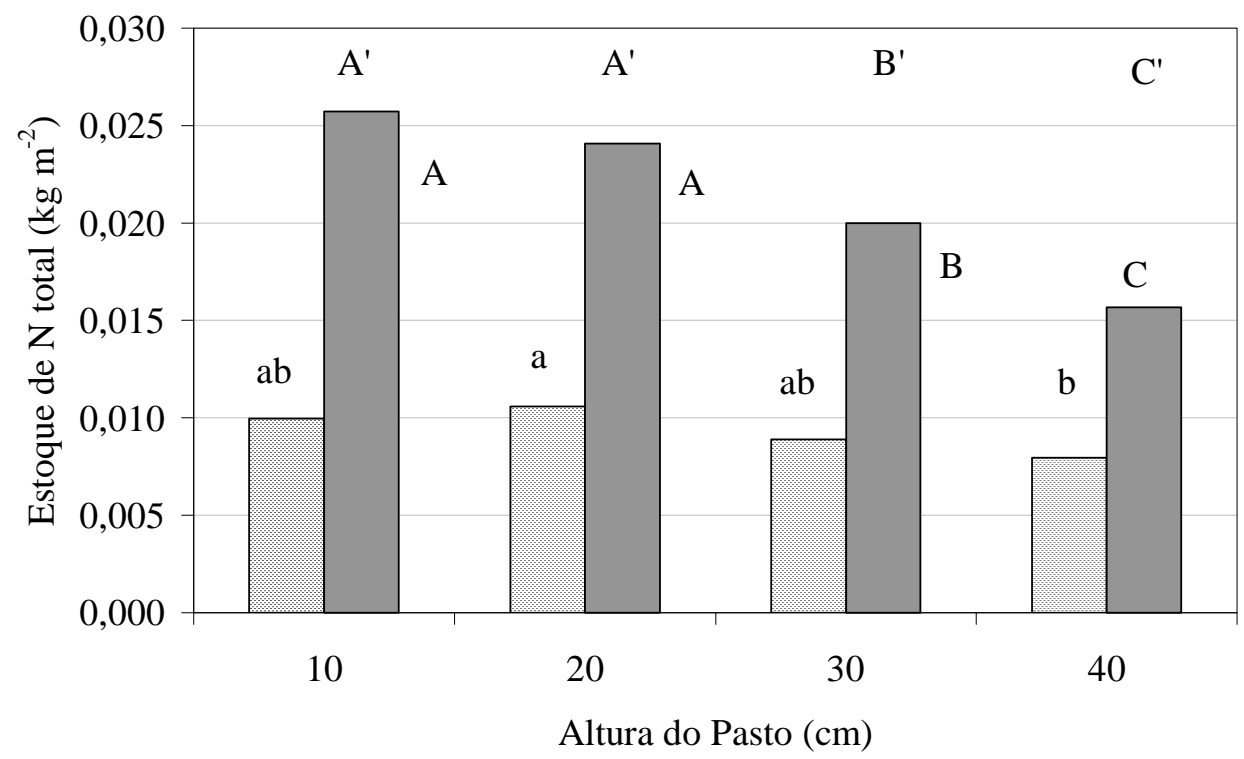

$\square \mathrm{SR} \quad \square \mathrm{PA}$

Figura 23 - Estoques de $\mathrm{N}$ total no sistema radicular (SR) e na parte aérea (PA) de braquiária brizanta mantida em diferentes alturas de pasto.

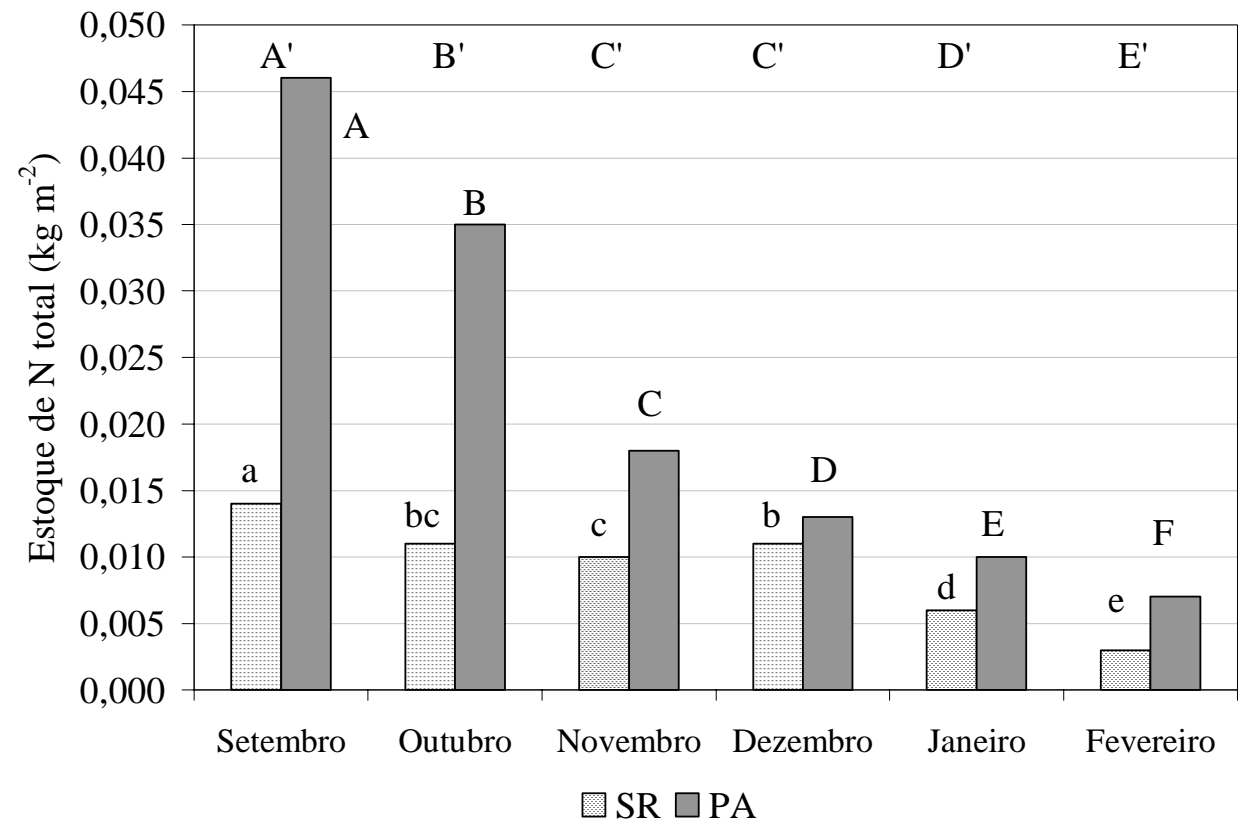

Figura 24 - Estoques de $\mathrm{N}$ total no sistema radicular (SR) e na parte aérea (PA) de pastos de braquiária brizanta, de setembro de 2001 a fevereiro de 2002. 
Com relação à parte da planta, observou-se um maior estoque na parte aérea em comparação com o sistema radicular, o que devido à inexistência de diferenças entre os teores de $\mathrm{N}$ total, seria justificado como consequência direta da maior massa da parte aérea em comparação ao sistema radicular, conforme apresentado no item 4.2. A redução nos estoques de $\mathrm{N}$ total foram mais drásticas na parte aérea relativamente ao sistema radicular, provavelmente consequência da maior proximidade desse órgão de reserva em relação aos drenos metabólicos da planta (meristemas apicais vegetativos e reprodutivos).

\subsubsection{Nitrogênio solúvel ( $\mathrm{N}$ solúvel)}

\subsection{Teores}

Os resultados referentes aos teores de $\mathrm{N}$ solúvel são mostrados nas Tabelas $12 \mathrm{e}$ 13 e nas Figuras 25, 26 e 27. Houve efeito de altura $(P=0,0573)$, mês $(P<0,0001)$, parte da planta $(\mathrm{P}=0,0251)$ e das interações altura x mês $(\mathrm{P}=0,0217)$ e parte da planta $\mathrm{x}$ mês $(\mathrm{P}=0,0177)$. A amplitude dos valores médios dos teores de $\mathrm{N}$ solúvel durante $\mathrm{o}$ experimento foi de 1,80 (40 cm, janeiro) a 7,20 g kg-1 (10 cm, setembro). O maior teor médio de $\mathrm{N}$ solúvel entre as alturas de pasto estudadas foi observado em $10 \mathrm{~cm}(4,81 \mathrm{~g}$ $\left.\mathrm{kg}^{-1}\right)$, o qual não diferiu da altura de $20 \mathrm{~cm}\left(4,22 \mathrm{~g} \mathrm{~kg}^{-1}\right)$, embora tenha sido distinto dos valores obtidos para $30\left(4,14 \mathrm{~g} \mathrm{~kg}^{-1}\right)$ e $40 \mathrm{~cm}\left(3,65 \mathrm{~g} \mathrm{~kg}^{-1}\right)$. Não houve diferenças entre os teores relativos às alturas de pasto de 20, 30 e $40 \mathrm{~cm}$ (Tabela 12). Com relação ao mês, assim como foi descrito para os teores de $\mathrm{N}$ total, foi notada uma redução dos teores de $\mathrm{N}$ solúvel ao longo do período experimental. Os teores médios observados nos meses de setembro $\left(6,02 \mathrm{~g} \mathrm{~kg}^{-1}\right)$ e outubro $\left(5,46 \mathrm{~g} \mathrm{~kg}^{-1}\right)$ não diferiram entre si sendo, no entanto, diferentes daqueles determinados para os demais meses (Figura 25). Os teores relativos aos meses de novembro (4,22 $\mathrm{g} \mathrm{kg}^{-1}$ ) e dezembro $\left(4,15 \mathrm{~g} \mathrm{~kg}^{-1}\right)$ foram semelhantes, embora distintos dos teores de janeiro $\left(2,44 \mathrm{~g} \mathrm{~kg}^{-1}\right)$ e fevereiro $(2,95$

$\mathrm{g} \mathrm{kg}^{-1}$ ), sendo que esses foram semelhantes entre si (Tabela 12 e Figura 26). Em relação à parte da planta, os teores de $\mathrm{N}$ solúvel foram mais elevados no sistema radicular 
Tabela 12. Teores de $\mathrm{N}$ solúvel $\left(\mathrm{g} \mathrm{kg}^{-1}\right)$ em braquiária brizanta mantida em diferentes alturas de pasto, de setembro de 2001 a fevereiro de 2002.

\begin{tabular}{|c|c|c|c|c|c|c|c|c|c|c|}
\hline \multirow{2}{*}{ Mês } & \multicolumn{8}{|c|}{ Altura do Pasto $(\mathrm{cm})$} & \multirow{2}{*}{ Média } & \multirow{2}{*}{$\mathrm{EPM}^{*}$} \\
\hline & \multicolumn{2}{|l|}{10} & \multicolumn{2}{|c|}{20} & \multicolumn{2}{|l|}{30} & \multicolumn{2}{|l|}{40} & & \\
\hline Setembro & 7,20 & $\mathrm{Aa}$ & 5,52 & $\mathrm{Ab}$ & 6,24 & Aab & 5,13 & $\mathrm{Ab}$ & $6,02^{\mathrm{A}}$ & 0,297 \\
\hline Outubro & 6,36 & $\mathrm{ABa}$ & 5,99 & Aab & 4,53 & $\mathrm{Bc}$ & 4,96 & $\mathrm{Abc}$ & $5,46^{\mathrm{A}}$ & 0,268 \\
\hline Novembro & 3,78 & $\mathrm{Cab}$ & 3,74 & $\mathrm{Bb}$ & 5,08 & $\mathrm{ABa}$ & 4,26 & $\mathrm{ABab}$ & $4,22^{\mathrm{B}}$ & 0,280 \\
\hline Dezembro & 5,58 & $\mathrm{Ba}$ & 3,78 & $\mathrm{Bbc}$ & 4,46 & Bab & 2,76 & $\mathrm{Cc}$ & $4,15^{\mathrm{B}}$ & 0,269 \\
\hline Janeiro & 2,97 & $\mathrm{Ca}$ & 2,62 & $\mathrm{Ba}$ & 2,39 & $\mathrm{Ca}$ & 1,80 & $\mathrm{Ca}$ & $2,44^{\mathrm{C}}$ & 0,292 \\
\hline Fevereiro & 2,96 & $\mathrm{Cab}$ & 3,66 & $\mathrm{Ba}$ & 2,16 & $\mathrm{Cb}$ & 3,02 & $\mathrm{BCab}$ & $2,95^{\mathrm{C}}$ & 0,279 \\
\hline Média & 4,81 & & 4,22 & & 4,14 & & 3,65 & & & \\
\hline $\mathrm{EPM}^{*}$ & 0,248 & & 0,248 & & 0,253 & & 0,248 & & & \\
\hline
\end{tabular}

*EPM - Erro padrão da média.

Médias na linha seguidas de mesmas letras minúsculas não diferem entre si $(\mathrm{P}>0,10)$.

Médias na coluna seguidas de mesmas letras maiúsculas não diferem entre si $(\mathrm{P}>0,10)$.

Tabela 13. Teores de nitrogênio solúvel $\left(\mathrm{g} \mathrm{kg}^{-1}\right)$ no sistema radicular (SR) e na parte aérea (PA) de pastos de braquiária brizanta, de setembro de 2001 a fevereiro de 2002.

\begin{tabular}{|c|c|c|c|c|c|c|}
\hline Mês & SR & & PA & & Média & EPM* \\
\hline Setembro & 6,39 & $\mathrm{Aa}$ & 5,65 & $\mathrm{Aa}$ & $6,02^{\mathrm{A}}$ & 0,297 \\
\hline Outubro & 5,26 & $\mathrm{Ba}$ & 5,66 & $\mathrm{Aa}$ & $5,46^{\mathrm{A}}$ & 0,268 \\
\hline Novembro & 4,85 & $\mathrm{BCa}$ & 3,58 & $\mathrm{BCb}$ & $4,22^{\mathrm{B}}$ & 0,280 \\
\hline Dezembro & 4,16 & $\mathrm{CDa}$ & 4,14 & $\mathrm{Ba}$ & $4,15^{\mathrm{B}}$ & 0,269 \\
\hline Janeiro & 3,31 & DEa & 1,58 & $\mathrm{Db}$ & $2,44^{\mathrm{C}}$ & 0,292 \\
\hline Fevereiro & 3,17 & $\mathrm{Ea}$ & 2,73 & $\mathrm{Ca}$ & $2,95^{\mathrm{C}}$ & 0,279 \\
\hline Média & 4,52 & $\mathrm{a}$ & 3,89 & & & \\
\hline $\mathrm{EPM}^{*}$ & 0,174 & & 0,178 & & & \\
\hline
\end{tabular}

*EPM - Erro padrão da média.

Médias na linha seguidas de mesmas letras minúsculas não diferem entre si $(\mathrm{P}>0,10)$.

Médias na coluna seguidas de mesmas letras maiúsculas não diferem entre si $(\mathrm{P}>0,10)$. 


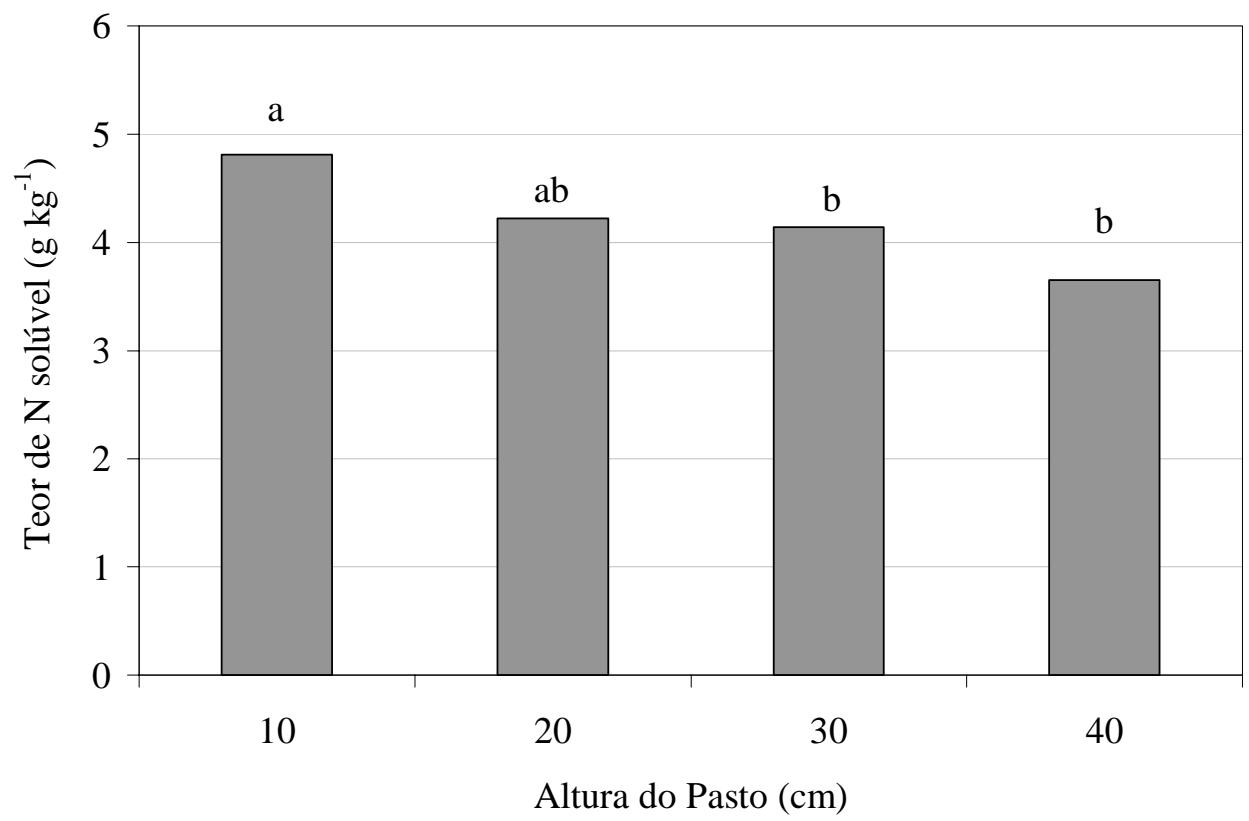

Figura 25 - Teores de N solúvel de braquiária brizanta mantida em diferentes alturas de pasto.

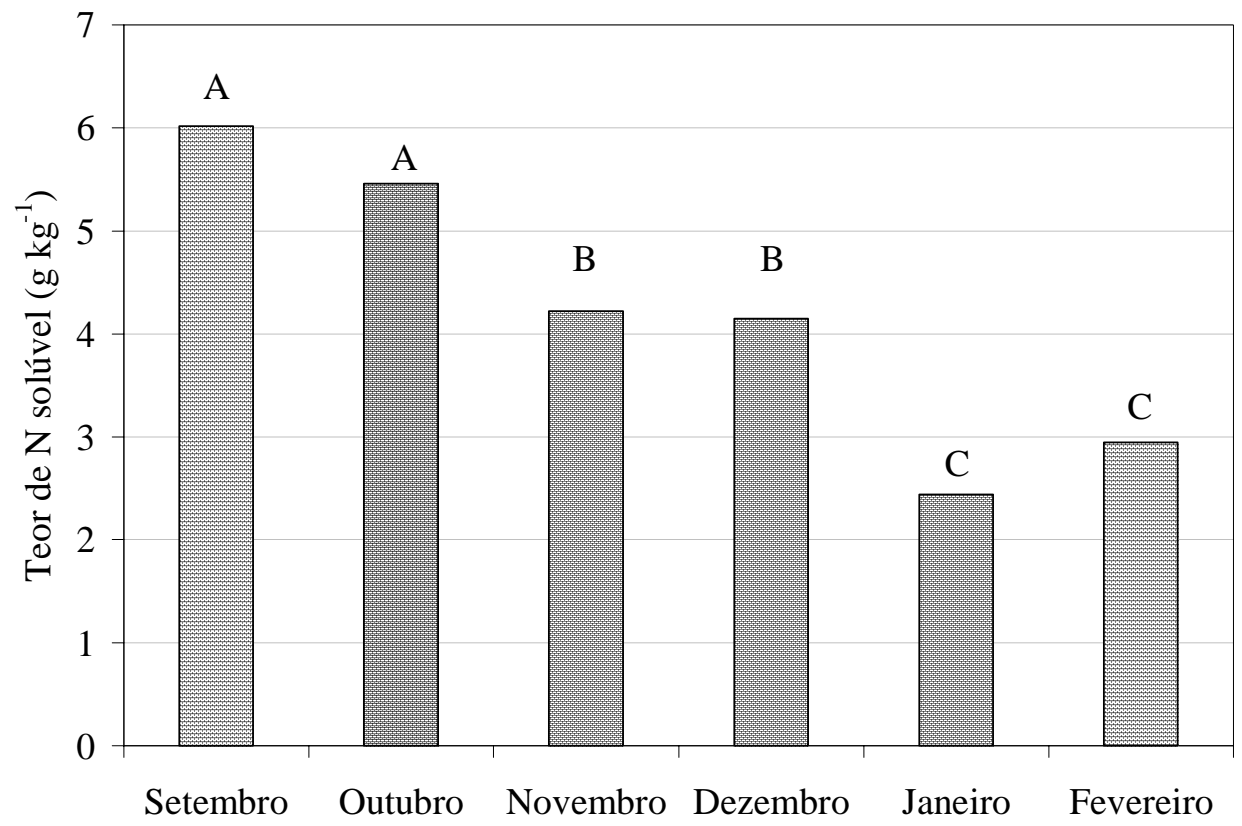

Figura 26 - Teores de N solúvel em pastos de braquiária brizanta, de setembro de 2001 a fevereiro de 2002. 


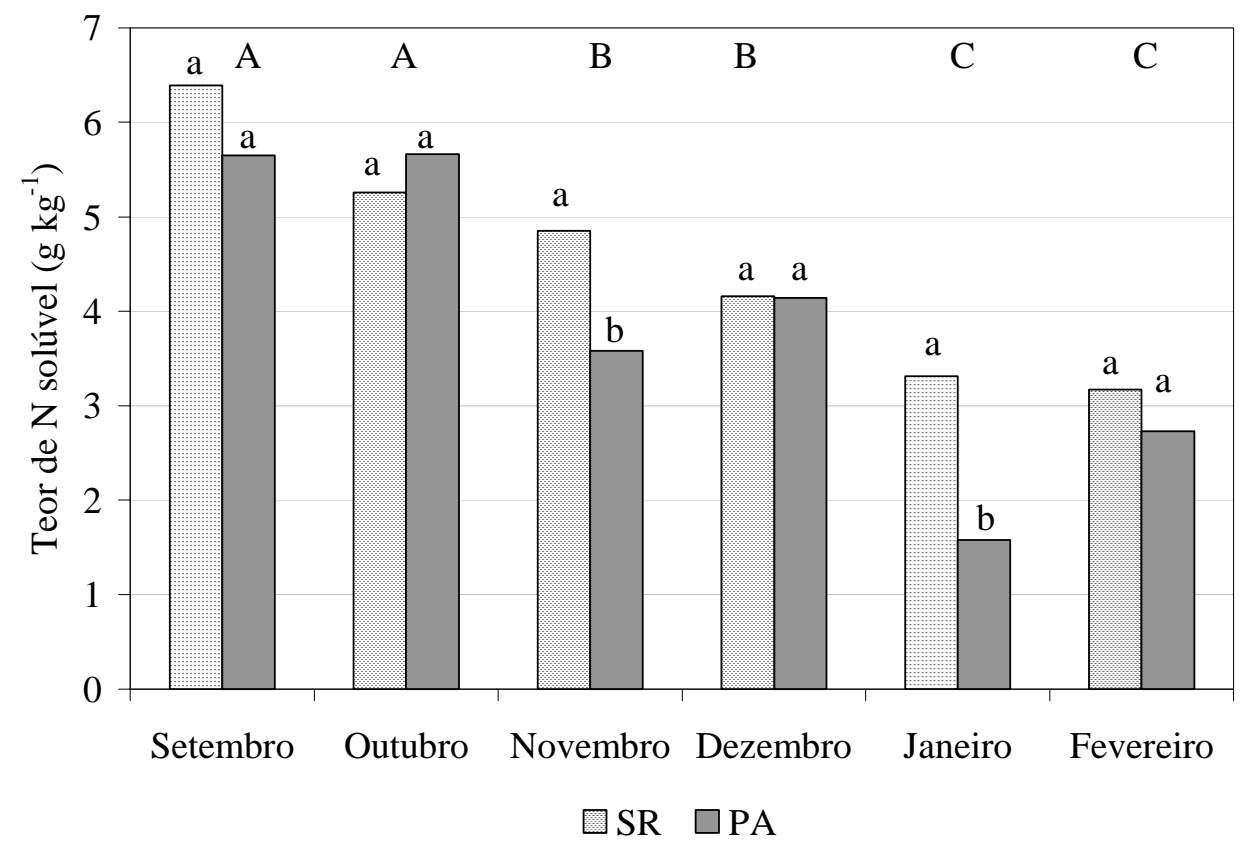

Figura 27 - Teores de N solúvel no sistema radicular (SR) e na parte aérea (PA) de pastos de braquiária brizanta, de setembro de 2001 a fevereiro de 2002.

(4,52 $\left.\mathrm{g} \mathrm{kg}^{-1}\right)$ em comparação com a parte aérea $\left(3,89 \mathrm{~g} \mathrm{~kg}^{-1}\right)$ (Tabela 13).

A determinação do $\mathrm{N}$ solúvel permitiu que fosse calculada a relação $\mathrm{N}$ solúvel/ $\mathrm{N}$ total, com a finalidade de verificar a existência de algum tipo de comportamento particular. Os resultados obtidos no experimento mostraram que para as condições de pasto estudadas os teores de $\mathrm{N}$ solúvel mantiveram certa proporcionalidade com os teores de $\mathrm{N}$ total, indicando que os tratamentos empregados não influenciaram essa relação. No entanto, quando a relação $\mathrm{N}$ solúvel/ $\mathrm{N}$ total foi calculada para as médias mensais, verificou-se proporcionalidade semelhante apenas durante os meses em que a braquiária se encontrava em estádio de desenvolvimento vegetativo (setembro a dezembro). Em janeiro e fevereiro, época em que a brizanta iniciou o estádio reprodutivo, foi verificada uma redução inicial na relação $\mathrm{N}$ solúvel/ $\mathrm{N}$ total, seguida por um aumento marcante, o que não permitiu assumir a existência de um comportamento padrão para essa relação ao longo do período experimental.

$\mathrm{O}$ padrão de comportamento dos teores médios de $\mathrm{N}$ solúvel relativo à amplitude de condições de pasto estudadas foi semelhante àquele relatado para os teores de $\mathrm{N}$ total 
(Figura 26), o que permitiu assumir que existe, entre as alturas de pasto estudadas, uma relação relativamente constante entre $\mathrm{N}$ solúvel e $\mathrm{N}$ total nos órgãos de reserva, que neste experimento variou, em média, de 0,45 $(10 \mathrm{~cm})$ a 0,52 (20 cm). Como consequência dessa proporcionalidade, as diferenças observadas nos teores de $\mathrm{N}$ solúvel poderiam ser consideradas mais como um resultado das diferenças mostradas para os teores de $\mathrm{N}$ total do que propriamente como um efeito das condições de pasto.

Com relação ao mês, foi observada uma redução nos teores de $\mathrm{N}$ solúvel ao longo do período experimental (Figura 27), assim como havia sido descrito para os teores de $\mathrm{N}$ total. A redução nos teores de $\mathrm{N}$ solúvel a partir dos meses de setembro/outubro poderia ser justificada considerando-se que provavelmente houve, num primeiro momento, um aumento nas taxas de acúmulo de forragem (novembro, dezembro e janeiro) e, a partir do mês de janeiro, com o início do estádio reprodutivo, com a intensificação da queda nos teores de $\mathrm{N}$ total e solúvel, foram observados os menores teores dessas frações. Esse fato aponta, uma vez mais, para a provável importância das inflorescências como fortes drenos metabólicos e determinantes da partição de carbono e nitrogênio em braquiária brizanta.

Conforme mencionado, notou-se que os padrões de redução dos teores de $\mathrm{N}$ total e solúvel foram específicos e distintos no período (Figura 28). Houve uma queda mais acentuada nos teores de $\mathrm{N}$ total relativamente aos teores de $\mathrm{N}$ solúvel, particularmente no mês de fevereiro, fato esse que não permitiu assumir a existência de uma proporção constante entre os teores dessas frações nitrogenadas durante todo o período experimental. Entre os meses de setembro e dezembro, a relação $\mathrm{N}$ solúvel/ $\mathrm{N}$ total variou entre 0,40 (novembro) e 0,47 (setembro), ao passo que em fevereiro aumentou para 0,76 .

A variação na relação $\mathrm{N}$ solúvel/N total poderia ser justificada por uma alteração na regulação hormonal das plantas superiores durante o estádio reprodutivo de desenvolvimento, conforme relatado por Davies (1995) e Rossato et al. (2002 a). Adicionalmente, o entendimento dos mecanismos que regulam a dinâmica do armazenamento e remobilização do nitrogênio na planta ainda é recente e incompleto, conforme foi apresentado por Volenec et al. (1996), Thornton et al. (2000), Gastal \& 
Lemaire (2002), Rossato et al. (2001, 2002 a, b), Stitt et al. (2002) e Takey et al. (2002), sendo que alguns desses autores indicaram a presença de compostos específicos, como por exemplo, o metil jasmonato (Rossato et al., 2002 a) ou mesmo o nitrato (Rossato et al., 2001; Takey et al., 2002) como modificadores da partição (relação fonte:dreno) de compostos nitrogenados dentro da planta. Rossato et al. (2002 a, b) relataram para soja e Arabidopsis thaliana que o metil jasmonato tem um papel significativo na partição de nitrogênio no tocante a alterações na relação fonte:dreno, bem como altos teores de metil jasmonato encontrados em flores e outros tecidos reprodutivos foram associados ao controle genético da produção, acúmulo e mobilização de proteínas de reserva (VSP vegetative storage proteins) na planta.

Nesse sentido, embora não exista nenhuma evidência clara na literatura a respeito da degradação e subseqüente mobilização de nitrogênio ou proteínas localizadas na parede celular durante o estádio reprodutivo, os dados sugerem que a alteração na

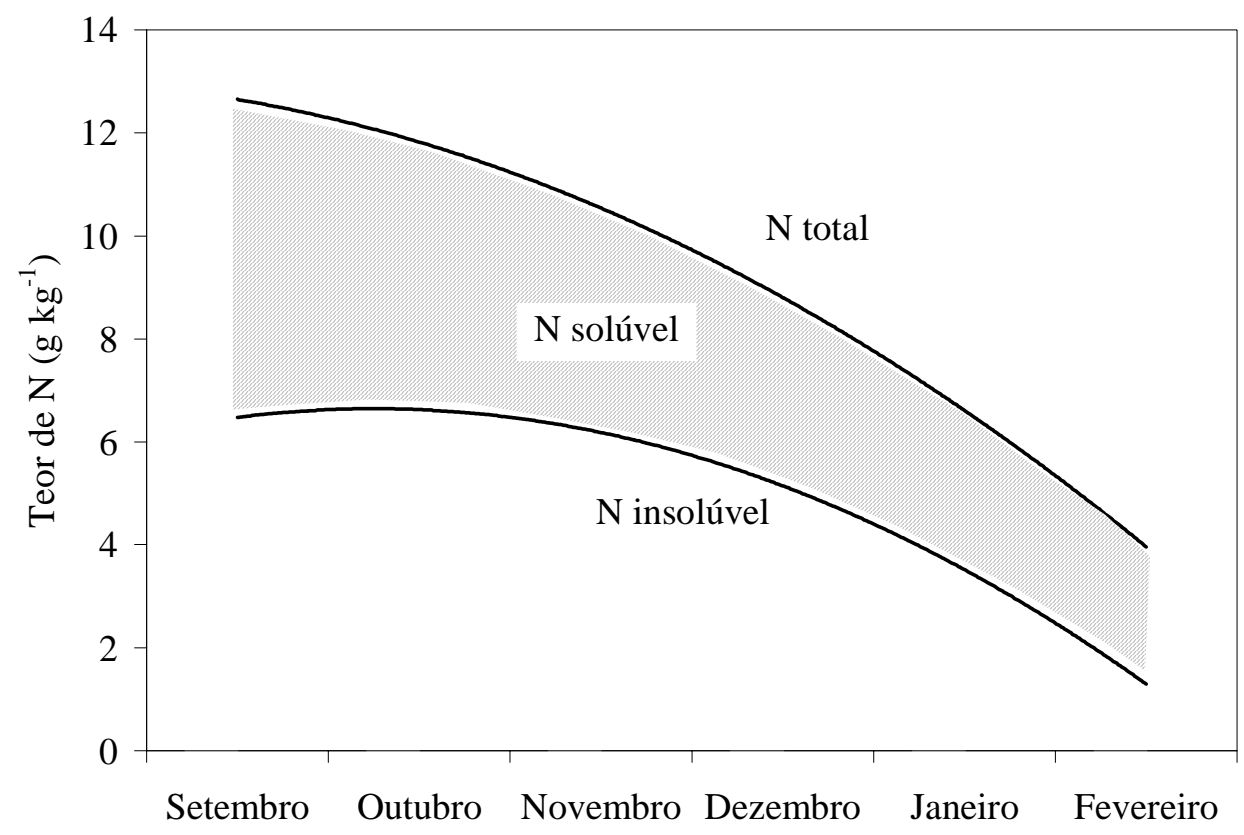

Figura 28 - Teores de $\mathrm{N}$ total e solúvel em pastos de braquiária brizanta, de setembro de 2001 a fevereiro de 2002 (linhas de tendência). 
proporção entre os teores de $\mathrm{N}$ total e solúvel poderia estar relacionada com a degradação da parede celular visando a mobilização de compostos nitrogenados para a utilização na formação de inflorescências e sementes.

Com relação à parte da planta, foram observadas diferenças somente nos meses de novembro e janeiro, sendo notado um maior teor de $\mathrm{N}$ solúvel no sistema radicular em comparação à parte aérea em ambos os meses. Em novembro, a diferença entre os teores relativos às partes da planta dever ter sido associada, provavelmente, à mobilização de reservas de $\mathrm{N}$ solúvel da parte aérea (maior proximidade dos pontos de crescimento dos perfilhos), devido ao aumento da taxa de acúmulo de forragem, visto que havia condições climáticas favoráveis ao crescimento da planta forrageira. Já em janeiro, com o início do estádio reprodutivo, uma vez mais a planta fez uso intenso do nitrogênio solúvel, possivelmente para suprir a demanda dos meristemas reprodutivos existentes. Além disso, é pertinente considerar que uma das prováveis causas que contribuíram para a inexistência de reduções significativas nos teores de $\mathrm{N}$ solúvel nas partes da planta nos meses de dezembro e fevereiro, tenha sido a realização de adubações nitrogenadas previamente às avaliações relativas a esses meses.

\subsection{Estoques}

Os resultados referentes aos estoques de N solúvel são mostrados na Tabela 14 e nas Figuras 29 e 30. Houve efeito de altura $(\mathrm{P}=0,0042)$, mês $(\mathrm{P}<0,0001)$, parte da planta $(\mathrm{P}<0,0001)$ e das interações altura $\mathrm{x}$ mês $(\mathrm{P}=0,0004)$, altura $\mathrm{x}$ parte da planta $(\mathrm{P}=0,0930)$, parte da planta $\mathrm{x}$ mês $(\mathrm{P}<0,0001)$ e altura $\mathrm{x}$ parte da planta $\mathrm{x}$ mês $(\mathrm{P}=0,0711)$. A amplitude dos valores médios dos estoques de $\mathrm{N}$ solúvel durante $\mathrm{o}$ período experimental foi de 0,001 $(40 \mathrm{~cm}$, parte aérea, janeiro; $30 \mathrm{~cm}$, sistema radicular, fevereiro) a $0,029 \mathrm{~kg} \mathrm{~m}^{-2}$ (10 cm, parte aérea, setembro) (Tabela 14). A altura de pasto

de $10 \mathrm{~cm}\left(0,009 \mathrm{~kg} \mathrm{~m}^{-2}\right)$ apresentou o maior valor médio de estoque durante o experimento, o qual diferiu dos valores relativos as demais alturas de pasto estudadas (Figura 29). Os valores médios de estoque das alturas de $20\left(0,007 \mathrm{~kg} \mathrm{~m}^{-2}\right)$ e $30 \mathrm{~cm}$ 
Tabela 14. Estoques de nitrogênio solúvel $\left(\mathrm{kg} \mathrm{m}^{-2}\right)$ no sistema radicular $(\mathrm{SR})$ e na parte aérea (PA) de braquiária brizanta mantida em quatro alturas de pasto, de setembro de 2001 a fevereiro de 2002.

\begin{tabular}{|c|c|c|c|c|c|c|c|c|c|c|}
\hline \multirow{2}{*}{$\begin{array}{c}\text { Altura do } \\
\text { Pasto }\end{array}$} & \multicolumn{6}{|c|}{ Parte da Planta } & \multirow{2}{*}{\multicolumn{3}{|c|}{ Média }} & \multirow{2}{*}{$\begin{array}{l}\text { Média } \\
\text { do Mês }\end{array}$} \\
\hline & & $\mathrm{SF}$ & & & $\mathrm{P}$ & & & & & \\
\hline \multicolumn{11}{|c|}{ Setembro - 2001} \\
\hline 10 & 0,009 & $\mathrm{Ab}$ & $(0,0015)$ & 0,029 & & $(0,0015)$ & 0,019 & A & $(0,0011)$ & \\
\hline 20 & 0,007 & $\mathrm{Ab}$ & $(0,0015)$ & 0,018 & $\mathrm{Ba}$ & $(0,0015)$ & 0,012 & B & $(0,0011)$ & $0,014^{\mathrm{A}^{\prime}}$ \\
\hline 30 & 0,009 & $\mathrm{Ab}$ & $(0,0010)$ & 0,018 & $\mathrm{Ba}$ & $(0,0057)$ & 0,014 & B & $(0,0030)$ & \\
\hline 40 & 0,007 & $\mathrm{Ab}$ & $(0,0017)$ & 0,015 & $\mathrm{Ba}$ & $(0,0018)$ & 0,011 & B & $(0,0012)$ & $(0,0005$ \\
\hline Média & 0,008 & $\mathrm{~b}$ & $(0,0008)$ & 0,020 & & $(0,0016)$ & & & & \\
\hline \multicolumn{11}{|c|}{ Outubro - 2001} \\
\hline 10 & 0,006 & $\mathrm{Ab}$ & $(0,0009)$ & 0,022 & Aa & $(0,0040)$ & 0,014 & A & $(0,0021)$ & \\
\hline 20 & 0,007 & $\mathrm{Ab}$ & $(0,0010)$ & 0,018 & $\mathrm{ABa}$ & $(0,0015)$ & 0,012 & $\mathrm{AB}$ & $(0,0023)$ & $0,011^{\mathrm{B}}$ \\
\hline 30 & 0,003 & $\mathrm{Bb}$ & $(0,0010)$ & 0,014 & $\mathrm{ABa}$ & $(0,0046)$ & 0,009 & B & $(0,0024)$ & \\
\hline 40 & 0,006 & $\mathrm{Ab}$ & $(0,0010)$ & 0,012 & $\mathrm{Ba}$ & $(0,0015)$ & 0,009 & B & $(0,0009)$ & $(0,0010)$ \\
\hline Média & 0,005 & $\mathrm{~b}$ & $(0,0005)$ & 0,017 & & $(0,0019)$ & & & & \\
\hline \multicolumn{11}{|c|}{ Novembro -2001} \\
\hline 10 & 0,005 & Aa & $(0,0010)$ & 0,006 & $\mathrm{Aa}$ & $(0,0018)$ & 0,005 & $\mathrm{AB}$ & $(0,0010)$ & \\
\hline 20 & 0,005 & Aa & $(0,0009)$ & 0,005 & $\mathrm{Aa}$ & $(0,0018)$ & 0,005 & $\mathrm{AB}$ & $(0,0010)$ & $0,005^{\mathrm{C}}$ \\
\hline 30 & 0,005 & $\mathrm{Ab}$ & $(0,0011)$ & 0,008 & $\mathrm{Aa}$ & $(0,0014)$ & 0,006 & A & $(0,0009)$ & 8000 \\
\hline 40 & 0,003 & Aa & $(0,0010)$ & 0,005 & $\mathrm{Aa}$ & $(0,0018)$ & 0,004 & B & $(0$ & $(0,0005)$ \\
\hline Média & 0,004 & $\mathrm{~b}$ & $(0,0005)$ & 0,006 & & $(0,0009)$ & & & & \\
\hline \multicolumn{11}{|c|}{ Dezembro - 2001} \\
\hline 10 & 007 & $\mathrm{Ab}$ & $(0,0011)$ & 0,010 & $A_{i}$ & $(0,0011)$ & 0,008 & A & 08) & \\
\hline 20 & 0,006 & Aa & $(0,0010)$ & 0,004 & $\mathrm{Ba}$ & $(0,0012)$ & 0,005 & B & $(0,0008)$ & 0,005 \\
\hline 30 & 0,005 & Aa & $(0,0010)$ & 0,003 & $\mathrm{Ba}$ & $(0,0017)$ & 0,005 & B & $(0,0007)$ & \\
\hline 40 & 0,002 & $\mathrm{Ba}$ & $(0,0010)$ & 0,003 & $\mathrm{Ba}$ & $(0,0012)$ & 0,002 & $\mathrm{C}$ & $(0,0008)$ & 4) \\
\hline \multicolumn{11}{|c|}{ Janeiro - 2002} \\
\hline 10 & 0,005 & $\mathrm{Aa}$ & $(0,0049)$ & 0,002 & $\mathrm{Aa}$ & $(0,0015)$ & 0,004 & A & $(0,0009)$ & \\
\hline 20 & 0,006 & Aa & $(0,0010)$ & 0,002 & $\mathrm{Ab}$ & $(0,0018)$ & 0,003 & A & $(0,0010)$ & $0,003^{D^{\prime}}$ \\
\hline 30 & 0,002 & Ba & $(0,0010)$ & 0,003 & $\mathrm{Aa}$ & $(0,0017)$ & 0,003 & A & $(0,0010)$ & (0005005) \\
\hline 40 & 0,002 & $\mathrm{Ba}$ & $(0,0010)$ & 0,001 & Aa & $(0,0016)$ & 0,002 & A & $(0,0009)$ & $0003)$ \\
\hline Média & 0,003 & $\mathrm{a}$ & $(0,0005)$ & 0,002 & $\mathrm{a}$ & $(0,0008)$ & & & & \\
\hline \multicolumn{11}{|c|}{ Fevereiro - 2002} \\
\hline 10 & 0,003 & Aa & $(0,0008)$ & 0,005 & Aa & $(0,0009)$ & 0,004 & A & $(0,0006)$ & \\
\hline 20 & 0,003 & $\mathrm{Ab}$ & $(0,0010)$ & 0,006 & $\mathrm{Aa}$ & $(0,0009)$ & 0,005 & A & $(0,0006)$ & $0,003^{\mathrm{D}}$ \\
\hline 30 & 0,001 & Aa & $(0,0009)$ & 0,002 & $\mathrm{Aa}$ & $(0,0012)$ & 0,002 & B & $(0,0007)$ & \\
\hline 40 & 0,003 & Aa & $(0,0009)$ & 0,004 & $\mathrm{Aa}$ & $(0,0008)$ & 0,003 & $\mathrm{AB}$ & $(0,0006)$ & $0003)$ \\
\hline Média & 0,003 & b & $(0,0004)$ & 0,004 & a & $(0,0005)$ & & & & \\
\hline
\end{tabular}

Valores entre parênteses indicam o Erro Padrão da Média (EPM).

Médias na linha seguidas de mesmas letras minúsculas não diferem entre si $(\mathrm{P}>0,10)$.

Médias na coluna seguidas de mesmas letras maiúsculas não diferem entre si $(P>0,10)$. 


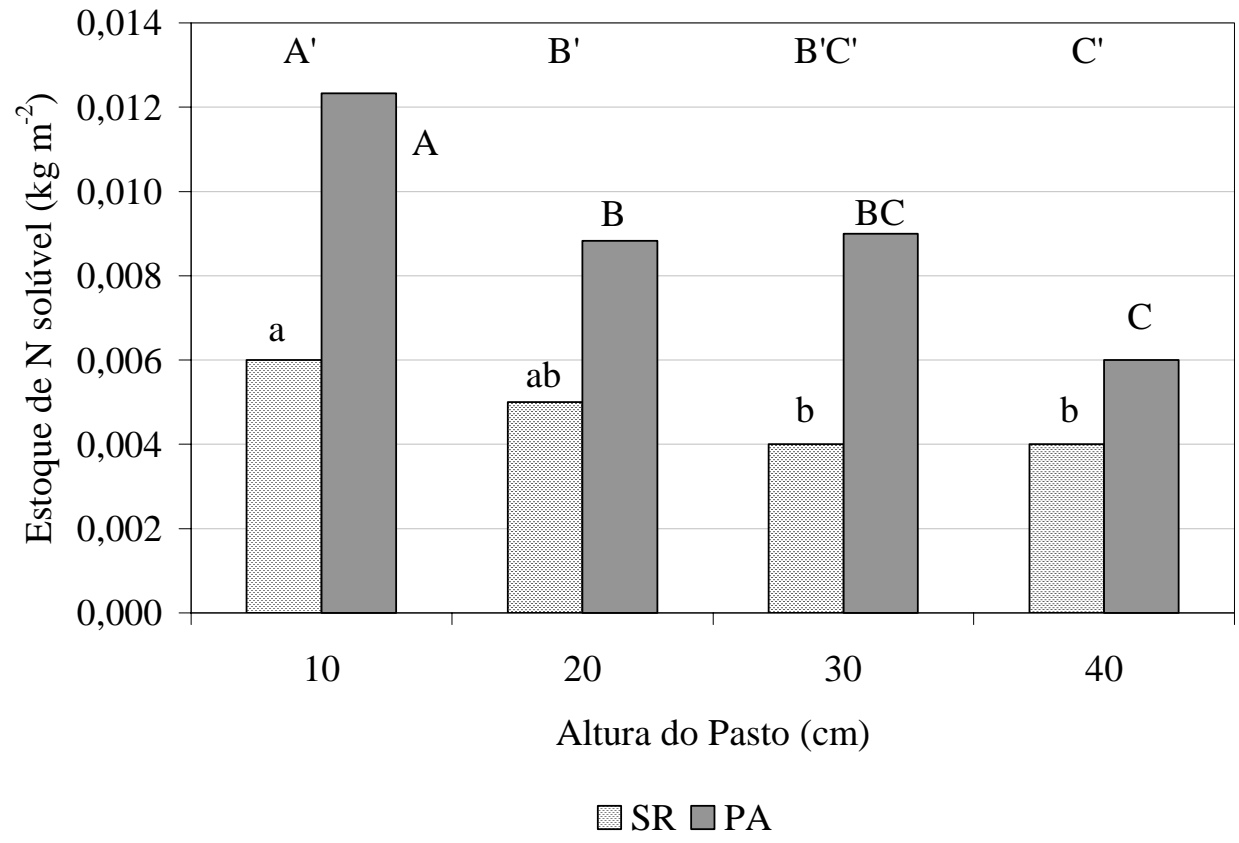

Figura 29 - Estoques de N solúvel no sistema radicular (SR) e na parte aérea (PA) de braquiária brizanta mantida em diferentes alturas de pasto.

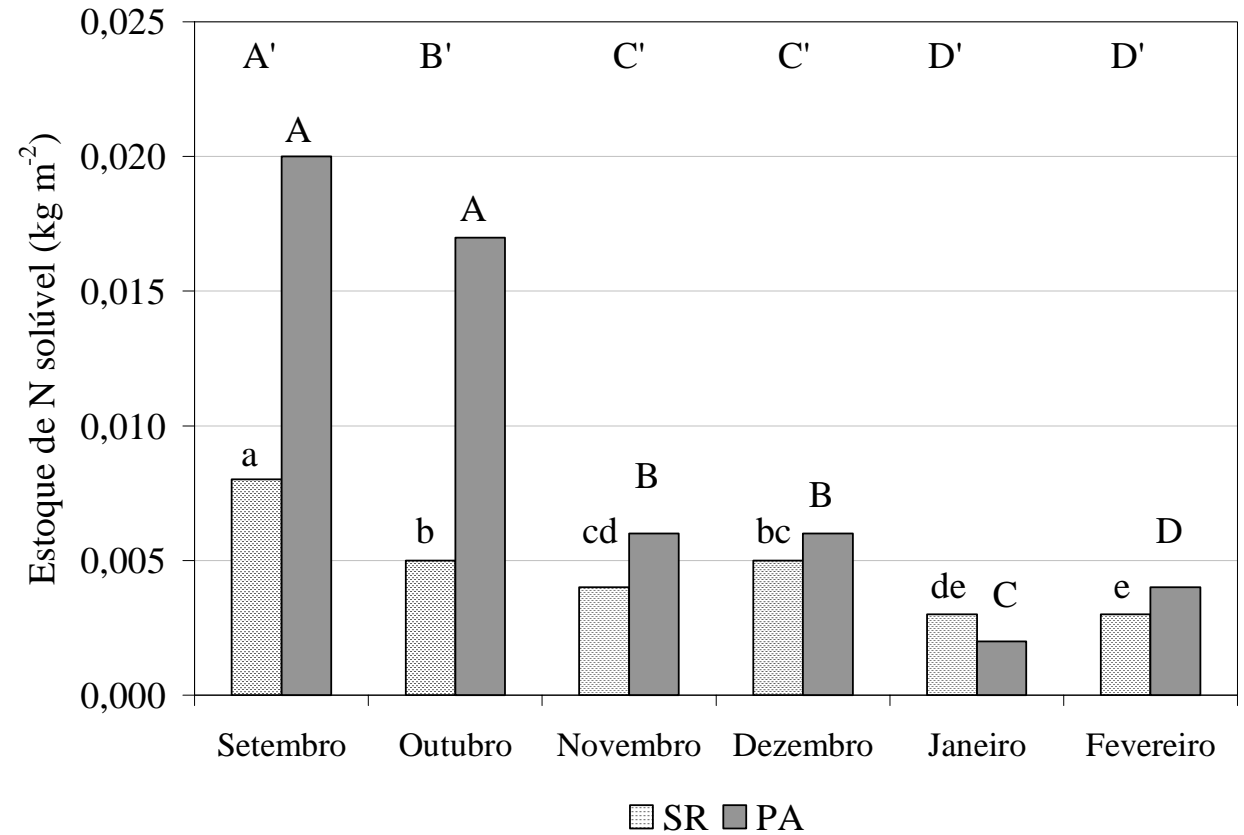

Figura 30 - Estoques de N solúvel no sistema radicular (SR) e na parte aérea (PA) de pastos de braquiária brizanta, de setembro de 2001 a fevereiro de 2002. 
$\left(0,006 \mathrm{~kg} \mathrm{~m}^{-2}\right)$ não diferiram entre si. $\mathrm{O}$ estoque médio da altura de $20 \mathrm{~cm}$ foi distinto daquele observado para a altura de $40 \mathrm{~cm}\left(0,005 \mathrm{~kg} \mathrm{~m}^{-2}\right)$, ao passo que entre as alturas de pasto de 30 e $40 \mathrm{~cm}$ não foram detectadas diferenças (Figura 29). Com relação ao mês, houve redução nos estoques de $\mathrm{N}$ solúvel durante o período experimental seguindo o mesmo padrão relatado para os teores de N solúvel (Figura 30). O maior valor médio de estoque de $\mathrm{N}$ solúvel foi encontrado no mês de setembro $\left(0,014 \mathrm{~kg} \mathrm{~m}^{-2}\right)$, ao passo que o menor valor foi relativo ao mês de janeiro $\left(0,003 \mathrm{~kg} \mathrm{~m}^{-2}\right)$. O estoque médio obtido em setembro foi diferente dos valores observados nos outros meses. O mesmo foi notado para o estoque médio de outubro $\left(0,011 \mathrm{~kg} \mathrm{~m}^{-2}\right)$. Os estoques médios de $\mathrm{N}$ solúvel de novembro $\left(0,005 \mathrm{~kg} \mathrm{~m}^{-2}\right)$ e dezembro $\left(0,006 \mathrm{~kg} \mathrm{~m}^{-2}\right)$ e, de janeiro $\left(0,003 \mathrm{~kg} \mathrm{~m}^{-2}\right)$ e fevereiro $\left(0,004 \mathrm{~kg} \mathrm{~m}^{-2}\right)$, não diferiram entre si (Figura 30). Quanto à parte da planta, os maiores valores de estoque de $\mathrm{N}$ solúvel foram encontrados, consistentemente, na parte aérea, exceção feita ao mês de janeiro (Figura 30). O valor médio da parte aérea $(0,009$ $\mathrm{kg} \mathrm{m}^{-2}$ ) ao longo do período experimental diferiu daquele relativo ao sistema radicular $\left(0,005 \mathrm{~kg} \mathrm{~m}^{-2}\right)$.

$\mathrm{O}$ padrão de comportamento revelado pelos estoques de $\mathrm{N}$ solúvel em relação às alturas de pasto estudadas foi decrescente (Figura 29), assim como já havia sido apresentado para os teores de $\mathrm{N}$ total e solúvel e para os estoques de $\mathrm{N}$ total. A provável explicação que justificaria esse comportamento estaria associada à maior taxa de renovação de tecidos nos pastos mantidos mais baixos, conforme discutido anteriormente.

Assim como relatado para os teores de $\mathrm{N}$ solúvel no tocante à relação $\mathrm{N}$ solúvel/N total, foi constatada também uma tendência de proporcionalidade entre os estoques de $\mathrm{N}$ solúvel e $\mathrm{N}$ total para as condições de pasto estudadas. Essa relação não se manteve constante ao longo do ano, principalmente devido às variações decorrentes do desenvolvimento reprodutivo iniciado em dezembro. Para as alturas de pasto a relação $\mathrm{N}$ solúvel/N total variou de $0,40(20 \mathrm{~cm})$ a 0,51 $(10 \mathrm{~cm})$.

O padrão de comportamento apresentado pelos estoques de $\mathrm{N}$ solúvel ao longo do período experimental foi semelhante àquele descrito para os teores de $\mathrm{N}$ solúvel, bem como para os estoques de $\mathrm{N}$ total, com a particularidade de que a redução nos estoques 
de $\mathrm{N}$ total foi mais acentuada em comparação com o $\mathrm{N}$ solúvel. Uma vez mais, foram marcantes os efeitos, inicialmente, do início da estação de crescimento, caracterizado pelo aumento da taxa de acúmulo entre os meses de setembro/outubro e novembro e, posteriormente, em janeiro, o início da fase de desenvolvimento reprodutivo, quando foram notadas reduções significativas nos estoques de N solúvel (Figura 30).

No tocante à proporcionalidade entre os estoques de $\mathrm{N}$ solúvel e $\mathrm{N}$ total, notou-se uma semelhança ao que foi descrito para os teores de $\mathrm{N}$ solúvel, sendo que a relação $\mathrm{N}$ solúvel/N total variou entre 0,37 (novembro) e 0,48 (outubro) durante a fase de desenvolvimento vegetativo, e atingiu 0,70 em fevereiro, durante a fase reprodutiva. Conforme discutido para os teores de $\mathrm{N}$ solúvel, essa variação na relação $\mathrm{N}$ solúvel/N total poderia estar associada ao aumento da produção de metil jasmonato, estimulada pela presença de estruturas reprodutivas, o qual atuaria modificando a regulação hormonal da planta de forma a resultar na mobilização e transporte de compostos nitrogenados presentes na parede celular para os novos drenos metabólicos, as inflorescências.

Com relação à parte da planta, o padrão de comportamento obtido para os estoques de $\mathrm{N}$ solúvel foi semelhante àquele descrito para os estoques de $\mathrm{N}$ total. Os maiores valores de estoque de $\mathrm{N}$ solúvel foram encontrados na parte aérea, à exceção dos meses de dezembro e janeiro, nos quais não houve diferenças entre os estoques nas partes da planta. Dado que as diferenças entre os teores de $\mathrm{N}$ solúvel foram pontuais (novembro e janeiro), a maior causa de variação entre os estoques de $\mathrm{N}$ solúvel foi a maior massa da parte aérea em relação ao sistema radicular, conforme os resultados apresentados no item 4.2. Assim como para $\mathrm{N}$ total, a redução nos estoques de $\mathrm{N}$ solúvel foi mais drástica na parte aérea relativamente ao sistema radicular, provavelmente consequência da maior proximidade desse órgão de reserva em relação aos drenos metabólicos da planta (meristemas apicais vegetativos e reprodutivos). 


\subsubsection{Nitrogênio em aminoácidos ( $\mathrm{N}$ aminoácidos)}

\subsubsection{Teores}

Os resultados referentes aos teores de $\mathrm{N}$ aminoácidos são mostrados na Tabela 15 e nas Figuras 31 e 32. Houve efeito de altura $(\mathrm{P}=0,0429)$, mês $(\mathrm{P}<0,0001)$ e da interação altura x mês $(\mathrm{P}=0,0719)$. A amplitude dos teores de $\mathrm{N}$ aminoácidos durante o período experimental foi de 189,8 (40 cm, parte aérea, janeiro) a 1930,0 mg kg-1 (10 cm, sistema radicular, setembro) (Tabela 15). Essa amplitude foi semelhante àquela apresentada por Gross (1988), para braquiária decumbens, que variou entre 230 e $2700 \mathrm{mg} \mathrm{kg}^{-1}$. O maior teor médio de $\mathrm{N}$ aminoácidos dentre as alturas de pasto estudadas foi obtido na altura de $20 \mathrm{~cm}\left(1177,3 \mathrm{mg} \mathrm{kg}^{-1}\right)$, o qual foi semelhante àquele determinado para a altura de 10 $\mathrm{cm}\left(1176,6 \mathrm{mg} \mathrm{kg}^{-1}\right)$. Ambos foram distintos dos teores observados para as alturas de 30 $\left(928,3 \mathrm{mg} \mathrm{kg}^{-1}\right)$ e $40 \mathrm{~cm}\left(888,4 \mathrm{mg} \mathrm{kg}^{-1}\right)$. Os valores de 30 e $40 \mathrm{~cm}$ foram semelhantes. Com relação ao mês, o maior teor de $\mathrm{N}$ aminoácidos foi obtido em setembro (1544,3

$\mathrm{mg} \mathrm{kg}^{-1}$ ), que por sua vez foi semelhante ao teor de outubro (1397,3 $\mathrm{mg} \mathrm{kg}^{-1}$ ). Ambos foram diferentes dos teores encontrados para os demais meses. $\mathrm{O}$ teor determinado para o mês de novembro $\left(1068,5 \mathrm{mg} \mathrm{kg}^{-1}\right)$ não diferiu do valor de dezembro $(1087,7$ $\left.\mathrm{mg} \mathrm{kg}^{-1}\right)$, embora tenham sido distintos daqueles observados para janeiro $(778,3$ $\left.\mathrm{mg} \mathrm{kg}^{-1}\right)$ e fevereiro $\left(379,7 \mathrm{mg} \mathrm{kg}^{-1}\right)$. Esses últimos diferiram entre si, de modo que mais uma vez o teor encontrado para o mês de fevereiro foi o menor do período experimental.

$\mathrm{O}$ padrão de comportamento dos teores médios de $\mathrm{N}$ aminoácidos no que diz respeito à amplitude de condições de pasto estudadas foi semelhante àqueles observados para os teores de $\mathrm{N}$ total e $\mathrm{N}$ solúvel, isto é, foi decrescente, de modo que os pastos mais baixos apresentaram os maiores teores de $\mathrm{N}$ aminoácidos. Esse padrão de comportamento poderia ser justificado considerando que nos pastos mais baixos a taxa de renovação de tecidos foi maior e, consequentemente, os tecidos existentes eram mais jovens e apresentavam atividade metabólica mais intensa em relação aos pastos mantidos mais altos, conforme foi relatado no item 4.3.2.1.1, referente aos teores de $\mathrm{N}$ total. 
Tabela 15. Teores de $\mathrm{N}$ aminoácidos $\left(\mathrm{mg} \mathrm{kg}^{-1}\right)$ em braquiária brizanta mantida em diferentes alturas de pasto, de setembro de 2001 a fevereiro de 2002.

\begin{tabular}{|c|c|c|c|c|c|c|c|c|c|c|c|}
\hline \multirow{2}{*}{ Mês } & \multicolumn{8}{|c|}{ Altura do Pasto (cm) } & \multirow{2}{*}{\multicolumn{2}{|c|}{ Média }} & \multirow{2}{*}{$\mathrm{EPM}^{*}$} \\
\hline & 10 & & 20 & & 30 & & 40 & & & & \\
\hline Setembro & 1753,4 & $\mathrm{Aa}$ & 1346,2 & $\mathrm{ABa}$ & 1359,8 & $\mathrm{ABa}$ & 1718,1 & $\mathrm{Aa}$ & 1544,3 & $\mathrm{~A}$ & 97,42 \\
\hline Outubro & 1287,5 & $\mathrm{Bb}$ & 1749,5 & Aa & 1455,8 & Aab & 1096,6 & $\mathrm{Bb}$ & 1397,3 & A & 91,99 \\
\hline Novembro & 1064,0 & $\mathrm{Ba}$ & 1091,8 & $\mathrm{BCa}$ & 967,3 & $\mathrm{Ba}$ & 1151,0 & $\mathrm{Ba}$ & 1068,5 & B & 100,88 \\
\hline Dezembro & 1247,7 & $\mathrm{Bab}$ & 1544,3 & $\mathrm{ABa}$ & 945,6 & $\mathrm{Bbc}$ & 613,4 & $\mathrm{Cc}$ & 1087,7 & B & 91,99 \\
\hline Janeiro & 1249,3 & $\mathrm{Ba}$ & 955,0 & $\mathrm{Ca}$ & 479,1 & $\mathrm{Cb}$ & 429,8 & $\mathrm{Cb}$ & 778,3 & $\mathrm{C}$ & 90,09 \\
\hline Fevereiro & 457,8 & $\mathrm{Ca}$ & 377,3 & $\mathrm{Da}$ & 362,5 & $\mathrm{Ca}$ & 321,4 & $\mathrm{Ca}$ & 379,7 & $\mathrm{D}$ & 90,09 \\
\hline Média & 1176,6 & a & 1177,3 & & 928,3 & $\mathrm{~b}$ & 888,4 & $\mathrm{~b}$ & & & \\
\hline $\mathrm{EPM}^{*}$ & 76,59 & & 77,60 & & 75,61 & & 76,77 & & & & \\
\hline
\end{tabular}

*EPM - Erro padrão da média.

Médias na linha seguidas de mesmas letras minúsculas não diferem entre si $(\mathrm{P}>0,10)$.

Médias na coluna seguidas de mesmas letras maiúsculas não diferem entre si $(P>0,10)$.

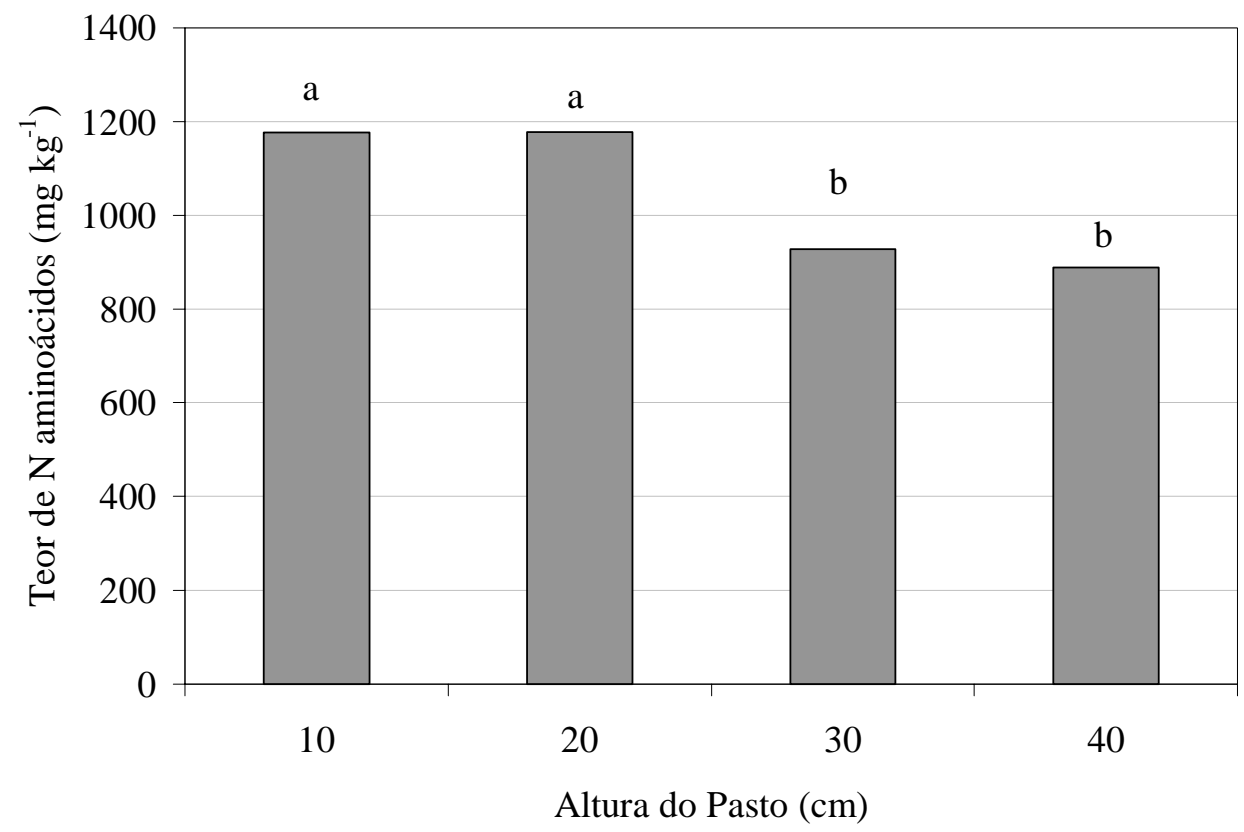

Figura 31 - Teores de $\mathrm{N}$ aminoácidos em braquiária brizanta mantida em diferentes alturas de pasto. 


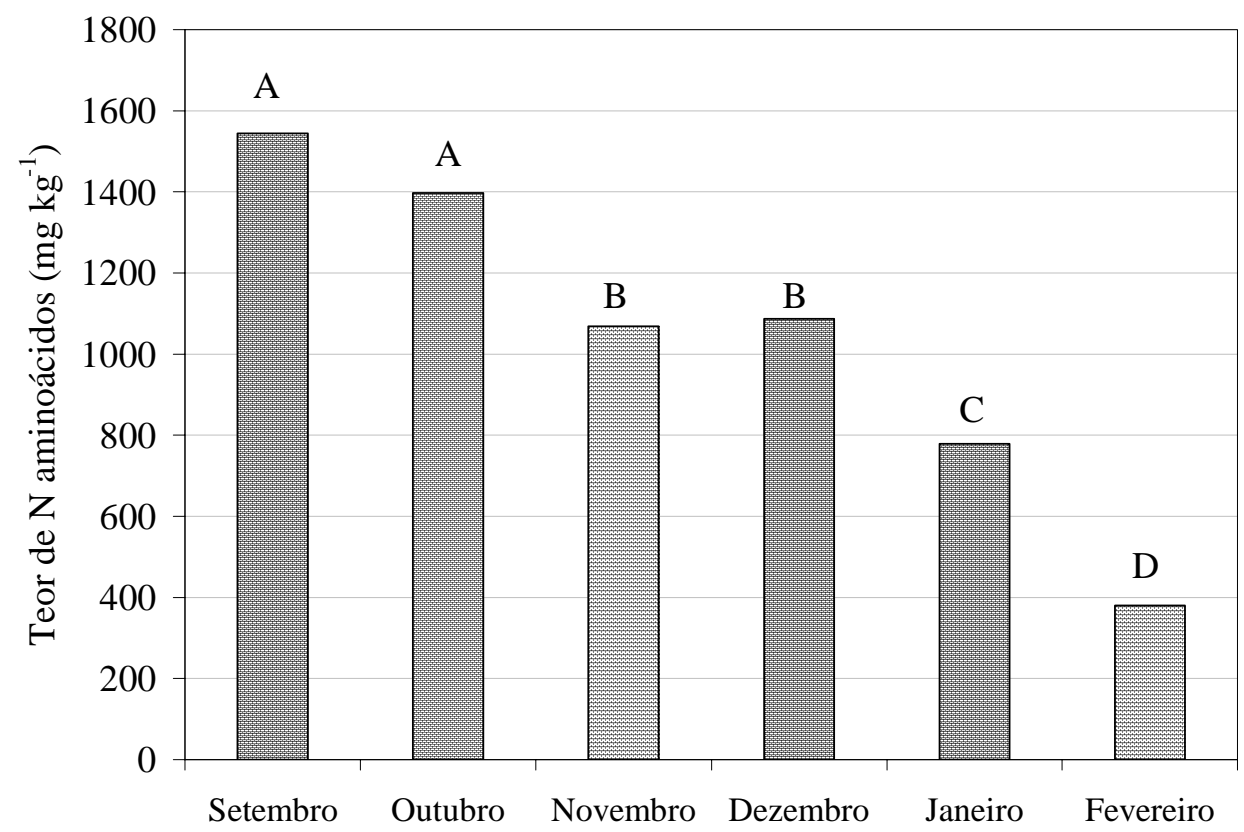

Figura 32 - Teores de N aminoácidos em pastos de braquiária brizanta, de setembro de 2001 a fevereiro de 2002.

Esse comportamento indica que embora a altura de pasto de $10 \mathrm{~cm}$ corresponda a um regime drástico de desfolha, essa condição ainda não poderia ser considerada como sendo correspondente àquela de uma pastagem em degradação ou degradada, visto que, de acordo com Gross (1988), as plantas mantidas em pastos em degradação apresentariam teores mais baixos de $\mathrm{N}$ aminoácidos em comparação às plantas manejadas adequadamente.

Com relação ao mês, os teores de $\mathrm{N}$ aminoácidos foram decrescentes ao longo do período experimental, assim como foi descrito para os teores de $\mathrm{N}$ total e $\mathrm{N}$ solúvel. Esse padrão de crescimento poderia ser explicado pelo crescimento das plantas (Volenec et al., 1996; Lemaire \& Gastal, 1997) no período compreendido entre setembro e dezembro e, posteriormente, entre janeiro e fevereiro, pela transição da fase vegetativa para a fase reprodutiva de desenvolvimento das plantas. Os teores observados em janeiro e fevereiro destacam, uma vez mais, a importância dos órgãos reprodutivos como drenos metabólicos. 


\subsection{Estoques}

Os resultados referentes aos estoques de $\mathrm{N}$ aminoácidos são mostrados na Tabela 16 e nas Figuras 33 e 34 . Houve efeito de mês $(\mathrm{P}<0,0001)$, parte da planta $(\mathrm{P}<0,0001)$ e da interação parte da planta x mês $(\mathrm{P}=0,0002)$. Não houve efeito de altura $(\mathrm{P}=0,1439)$. A amplitude dos estoques de $\mathrm{N}$ aminoácidos foi de 0,26 $(10 \mathrm{~cm}$, sistema radicular, fevereiro) a 5,96 $\mathrm{g} \mathrm{m}^{-2}$ (30 cm, parte aérea, outubro). Embora não tenha havido diferença entre as alturas de pasto estudadas, é pertinente considerar que houve uma tendência de queda nos estoques de $\mathrm{N}$ aminoácidos na medida em que as alturas de pasto aumentaram. Com relação ao mês, houve redução nos estoques de $\mathrm{N}$ aminoácidos durante o período experimental. O maior estoque foi obtido em setembro $\left(3,38 \mathrm{~g} \mathrm{~m}^{-2}\right)$, de modo que esse não diferiu do estoque correspondente ao mês de outubro $\left(3,26 \mathrm{~g} \mathrm{~m}^{-2}\right)$, embora ambos tenham sido diferentes dos demais. O estoque observado em novembro $\left(2,42 \mathrm{~g} \mathrm{~m}^{-2}\right)$, por sua vez, foi distinto dos demais, sendo que o mesmo foi notado para dezembro $\left(1,70 \mathrm{~g} \mathrm{~m}^{-2}\right)$. Os estoques de janeiro $\left(0,96 \mathrm{~g} \mathrm{~m}^{-2}\right)$ e fevereiro $\left(0,44 \mathrm{~g} \mathrm{~m}^{-2}\right)$ foram semelhantes e, também, os menores durante o período experimental. No tocante à parte da planta, o estoque médio relativo ao sistema radicular $\left(1,24 \mathrm{~g} \mathrm{~m}^{-2}\right)$ foi inferior àquele determinado para a parte aérea $\left(2,81 \mathrm{~g} \mathrm{~m}^{-2}\right)$.

$\mathrm{O}$ padrão de comportamento dos estoques de $\mathrm{N}$ aminoácidos durante $\mathrm{o}$ experimento foi decrescente, assim como já havia sido relatado para os estoques de $\mathrm{N}$ total e $\mathrm{N}$ solúvel. Ficou nítido que o início da estação de crescimento e o estádio reprodutivo tiveram um efeito significativo na redução dos estoques de $\mathrm{N}$ aminoácidos. No caso do crescimento, o efeito foi devido à produção de tecidos, principalmente folhas, motivado pela disponibilidade hídrica, temperatura e radiação solar favoráveis. No que diz respeito ao estádio reprodutivo, a produção de inflorescências e sementes exige uma grande quantidade de aminoácidos (proteínas, ácidos nucléicos, hormônios, enzimas), para suprir as necessidades de divisão e expansão celular e constituição de tecidos de reserva nas sementes (Taiz \& Zeiger, 1998).

Com relação à parte da planta, pode-se notar que os estoques de $\mathrm{N}$ aminoácidos acumulados na parte aérea foram, novamente, utilizados de forma mais intensa do que 
Tabela 16. Estoques de $\mathrm{N}$ aminoácidos $\left(\mathrm{g} \mathrm{m}^{-2}\right)$ no sistema radicular $(\mathrm{SR})$ e na parte aérea (PA) de pastos de braquiária brizanta, de setembro de 2001 a fevereiro de 2002.

\begin{tabular}{|c|c|c|c|c|c|c|}
\hline Mês & SR & & PA & & Média & $\mathrm{EPM}^{*}$ \\
\hline Setembro & 2,12 & $\mathrm{Ab}$ & 4,64 & Aa & $3,38 \quad \mathrm{~A}^{\prime}$ & 0,312 \\
\hline Outubro & 1,61 & $\mathrm{ABb}$ & 4,90 & Aa & $3,26^{A^{\prime}}$ & 0,295 \\
\hline Novembro & 1,05 & $\mathrm{Bb}$ & 3,79 & Aa & $2,42^{\mathrm{B}}$ & 0,295 \\
\hline Dezembro & 1,45 & $\mathrm{ABa}$ & 1,95 & $\mathrm{Ba}$ & $1,70^{\mathrm{C}}$ & 0,289 \\
\hline Janeiro & 0,91 & $\mathrm{BCa}$ & 1,02 & $\mathrm{BCa}$ & $0,96^{\mathrm{D}}$ & 0,289 \\
\hline Fevereiro & 0,30 & $\mathrm{Ca}$ & 0,57 & $\mathrm{Ca}$ & $0,44^{\mathrm{D}}$ & 0,289 \\
\hline Média & 1,24 & $\mathrm{~b}$ & 2,81 & a & & \\
\hline $\mathrm{EPM}^{*}$ & 0,169 & & 0,171 & & & \\
\hline
\end{tabular}

*EPM - Erro padrão da média.

Médias na linha seguidas de mesmas letras minúsculas não diferem entre si $(P>0,10)$.

Médias na coluna seguidas de mesmas letras maiúsculas não diferem entre si $(\mathrm{P}>0,10)$.

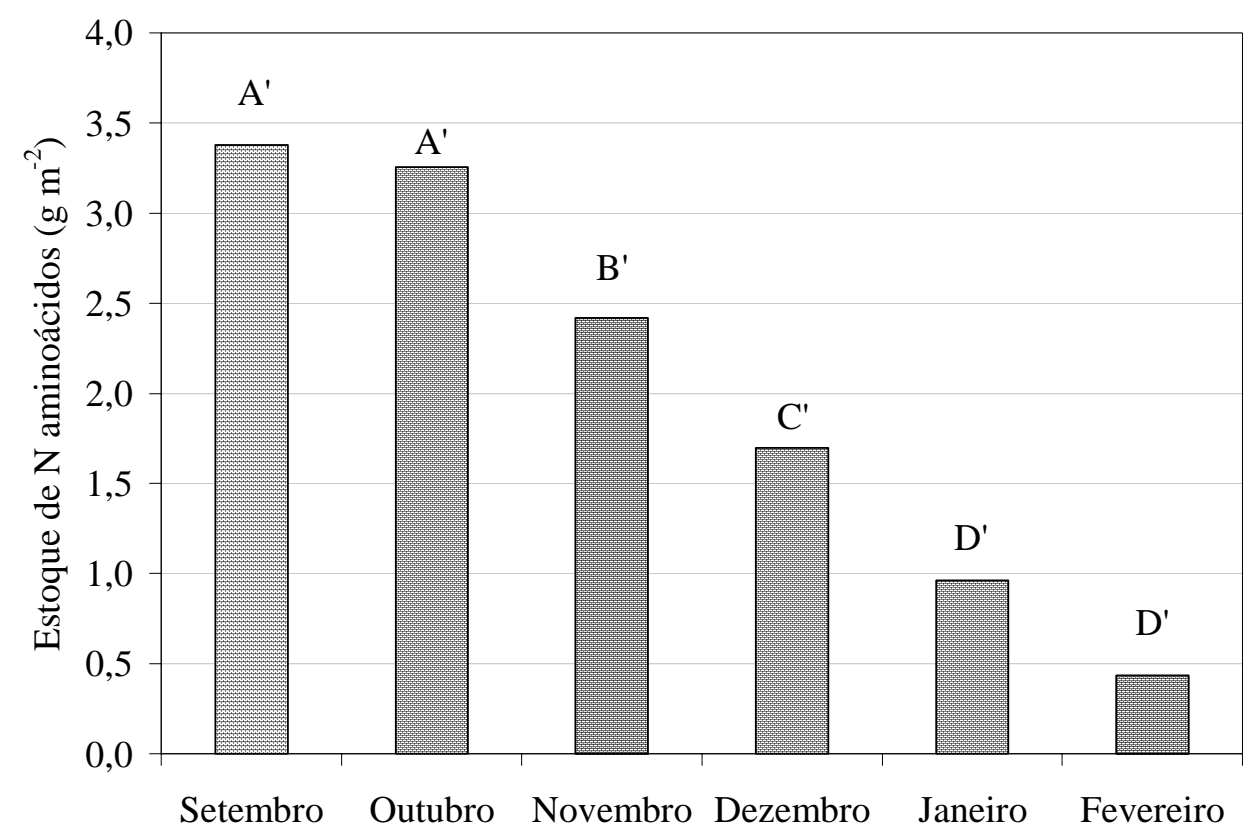

Figura 33 - Estoques de $\mathrm{N}$ aminoácidos em pastos de braquiária brizanta, de setembro de 2001 a fevereiro de 2002. 


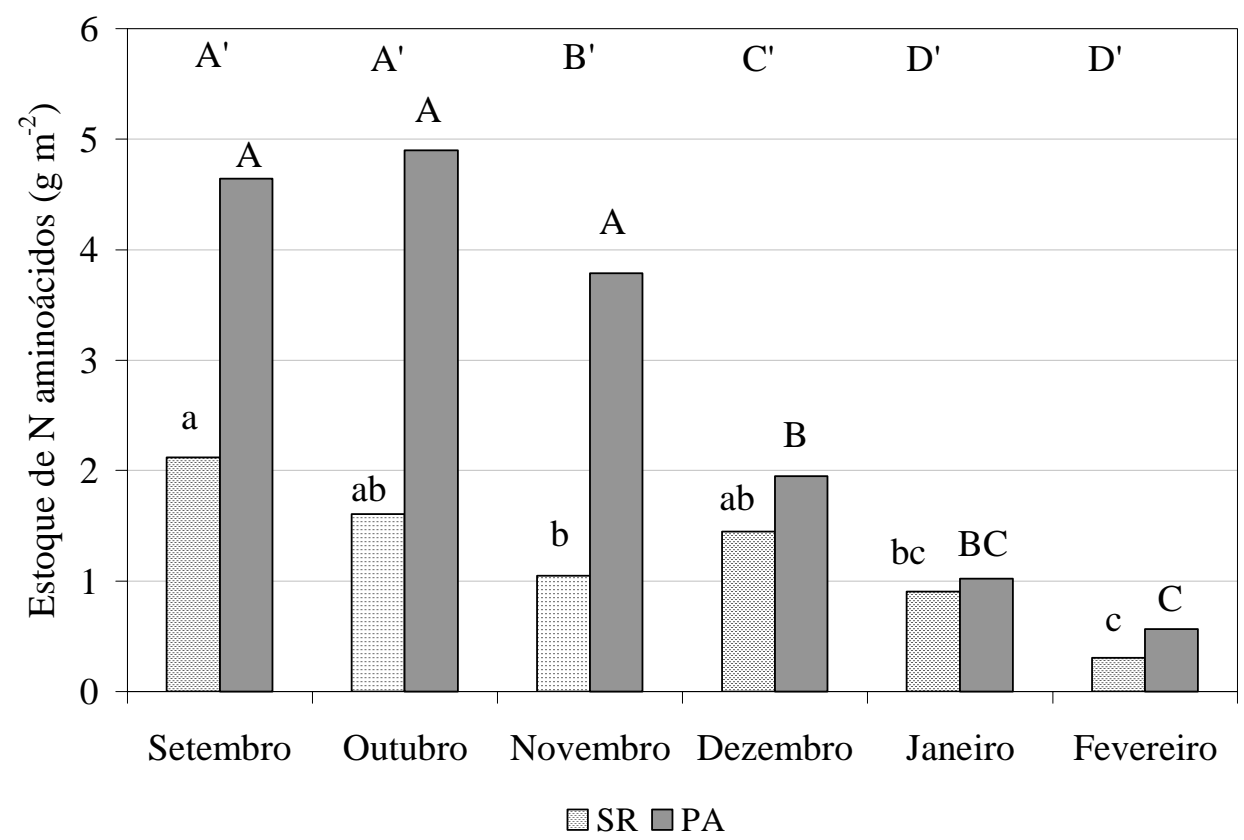

Figura 34 - Estoques de $\mathrm{N}$ aminoácidos no sistema radicular (SR) e na parte aérea (PA) de pastos de braquiária brizanta, de setembro de 2001 a fevereiro de 2002.

àqueles presentes no sistema radicular. A justificativa mais pertinente está associada a menor distância que existe entre os drenos metabólicos do dossel e esse órgão de reserva.

\subsubsection{Amônio $\left(\mathrm{NH}_{4}{ }^{+}\right)$}

\subsection{Teores}

Os resultados referentes aos teores de amônio são mostrados na Tabela 17 e nas Figuras 35,36 e 37. Houve efeito de altura $(\mathrm{P}=0,0019)$, mês ( $\mathrm{P}<0,0001)$, parte da planta $(\mathrm{P}=0,0014)$ e das interações altura $\mathrm{x}$ mês $(\mathrm{P}=0,0173)$, parte da planta $\mathrm{x}$ mês $(\mathrm{P}<0,0001) \mathrm{e}$ altura x parte da planta x mês $(\mathrm{P}=0,0513)$. A amplitude dos teores de amônio durante o período experimental foi de 251,3 (20 cm, fevereiro) a $1445,5 \mathrm{mg} \mathrm{kg}^{-1}(30 \mathrm{~cm}$, novembro) (Tabela 17). O maior teor médio de amônio dentre as alturas estudadas foi observado na altura de $10 \mathrm{~cm}\left(729,57 \mathrm{mg} \mathrm{kg}^{-1}\right)$, o qual diferiu das demais alturas. $\mathrm{O}$ teor 
Tabela 17. Teores de amônio $\left(\mathrm{mg} \mathrm{kg}^{-1}\right)$ no sistema radicular (SR) e na parte aérea (PA) (PA) de braquiária brizanta mantida em quatro alturas de pasto, de setembro de 2001 a fevereiro de 2002.

\begin{tabular}{|c|c|c|c|c|c|c|c|c|c|}
\hline \multirow{2}{*}{$\begin{array}{l}\text { Altura do } \\
\text { Pasto }(\mathrm{cm})\end{array}$} & \multicolumn{5}{|c|}{ Parte da Planta } & \multirow{2}{*}{\multicolumn{3}{|c|}{ Média }} & \multirow{2}{*}{$\begin{array}{c}\text { Média } \\
\text { do Mês }\end{array}$} \\
\hline & & \multicolumn{2}{|c|}{ SR } & \multicolumn{2}{|c|}{ PA } & & & & \\
\hline \multicolumn{10}{|c|}{ Setembro - 2001} \\
\hline 10 & 474,7 & & $(75,31)$ & 579,5 & $(75,31)$ & 527,1 & A & $(53,25)$ & \\
\hline 20 & 474,1 & & $(75,31)$ & 490,9 & $(75,31)$ & 482.5 & A & $(53,25)$ & $509,2^{\text {D' }}$ \\
\hline 30 & 480,1 & & $(75,31)$ & 611,7 & $(75,31)$ & 545,9 & A & $(53,25)$ & \\
\hline 40 & 460,6 & & $(75,31)$ & 501,9 & $(75,31)$ & 481,2 & A & $(53,25)$ & $(26,63)$ \\
\hline Média & 472,4 & a & $(37,66)$ & $546,0^{a}$ & $(37,66)$ & & & & \\
\hline \multicolumn{10}{|c|}{ Outubro - 2001} \\
\hline 10 & 506,5 & & $(75,31)$ & 1103,7 & $(75,31)$ & 805,1 & A & $(53,25)$ & \multirow{5}{*}{$\begin{array}{l}663,3^{B^{\prime}} \\
(26,63)\end{array}$} \\
\hline 20 & 497,5 & & $(75,31)$ & 977,8 & $(75,31)$ & 737,6 & A & $(53,25)$ & \\
\hline 30 & 483,3 & & $(75,31)$ & 633,6 & $(75,31)$ & 558,4 & B & $(53,25)$ & \\
\hline 40 & 421,3 & & $(75,31)$ & 682,4 & $(75,31)$ & 551,9 & B & $(53,25)$ & \\
\hline Média & 477,1 & \multirow[t]{2}{*}{$\mathrm{b}$} & $(37,65)$ & $849,4^{a}$ & $(37,66)$ & & & & \\
\hline \multicolumn{9}{|c|}{ Novembro - 2001} & \\
\hline 10 & 1286,4 & & $(87,21)$ & 1075,3 & $(75,31)$ & 1180,8 & $\mathrm{AB}$ & $(57,61)$ & \multirow{5}{*}{$\begin{array}{r}1128,5^{A} \\
(30,47)\end{array}$} \\
\hline 20 & 930,7 & & $(87,21)$ & 1158,4 & $(107,09)$ & 1044,6 & $\mathrm{BC}$ & $(69,21)$ & \\
\hline 30 & 1091,0 & & $(75,31)$ & 1445,5 & $(87,20)$ & 1268,2 & A & $(57,61)$ & \\
\hline 40 & 905,9 & & $(75,31)$ & 1135,1 & $(87,21)$ & 1020,5 & $\mathrm{C}$ & $(57,61)$ & \\
\hline Média & 1053,5 & \multirow[t]{2}{*}{$\mathrm{b}$} & $(40,80)$ & $1203,6^{\mathrm{a}}$ & $(45,06)$ & & & & \\
\hline \multicolumn{9}{|c|}{ Dezembro - 2001} & \\
\hline 10 & 695,7 & & $(75,31)$ & 716,8 & $(75,31)$ & 706,2 & A & $(53,25)$ & \multirow{5}{*}{$\begin{array}{r}572,65^{C^{\prime}} \\
(26,63)\end{array}$} \\
\hline 20 & 679,0 & & $(75,31)$ & 570,9 & $(75,31)$ & 624,9 & A & $(53,25)$ & \\
\hline 30 & 545,2 & & $(75,31)$ & 449,4 & $(75,31)$ & 497,3 & B & $(53,25)$ & \\
\hline 40 & 494,2 & & $(75,31)$ & 430,2 & $(75,31)$ & 462,2 & B & $(53,25)$ & \\
\hline Média & 603,5 & $\mathrm{a}$ & $(37,66)$ & $541,8^{a}$ & $(37,66)$ & & & & \\
\hline \multicolumn{10}{|c|}{ Janeiro - 2002} \\
\hline 10 & 711,7 & & $(75,31)$ & 857,3 & $(75,31)$ & 784,5 & A & $(53,25)$ & \multirow{5}{*}{$\begin{array}{l}597,4^{C} \\
(26,63)\end{array}$} \\
\hline 20 & 528,3 & & $(75,31)$ & 501,7 & $(75,31)$ & 515,0 & $\mathrm{BC}$ & $(53,25)$ & \\
\hline 30 & 619,1 & & $(75,31)$ & 636,1 & $(75,31)$ & 627,6 & B & $(53,25)$ & \\
\hline 40 & 479,5 & & $(75,31)$ & 445,7 & $(75,31)$ & 462,6 & $\mathrm{C}$ & $(53,25)$ & \\
\hline Média & 584,7 & $\mathrm{a}$ & $(37,66)$ & $610,2^{a}$ & $(37,65)$ & & & & \\
\hline \multicolumn{10}{|c|}{ Fevereiro - 2002} \\
\hline 10 & 370,8 & & $(75,31)$ & 376,6 & $(75,31)$ & 373,7 & A & $(53,25)$ & \multirow{5}{*}{$\begin{array}{l}302,9^{E} \\
(26,63)\end{array}$} \\
\hline 20 & 264,6 & & $(75,31)$ & 251,3 & $(75,31)$ & 258,0 & A & $(53,25)$ & \\
\hline 30 & 290,5 & & $(75,31)$ & 251,8 & $(75,31)$ & 271,2 & A & $(53,25)$ & \\
\hline 40 & 300,4 & & $(75,31)$ & 317,1 & $(75,31)$ & 308,7 & A & $(53,25)$ & \\
\hline Média & 306,6 & $\mathrm{a}$ & $(37,66)$ & $299,2^{\mathrm{a}}$ & $(37,66)$ & & & & \\
\hline
\end{tabular}

Valores entre parênteses indicam o Erro Padrão da Média (EPM).

Médias na linha seguidas de mesmas letras minúsculas não diferem entre si $(\mathrm{P}>0,10)$.

Médias na coluna seguidas de mesmas letras maiúsculas não diferem entre si $(\mathrm{P}>0,10)$. 


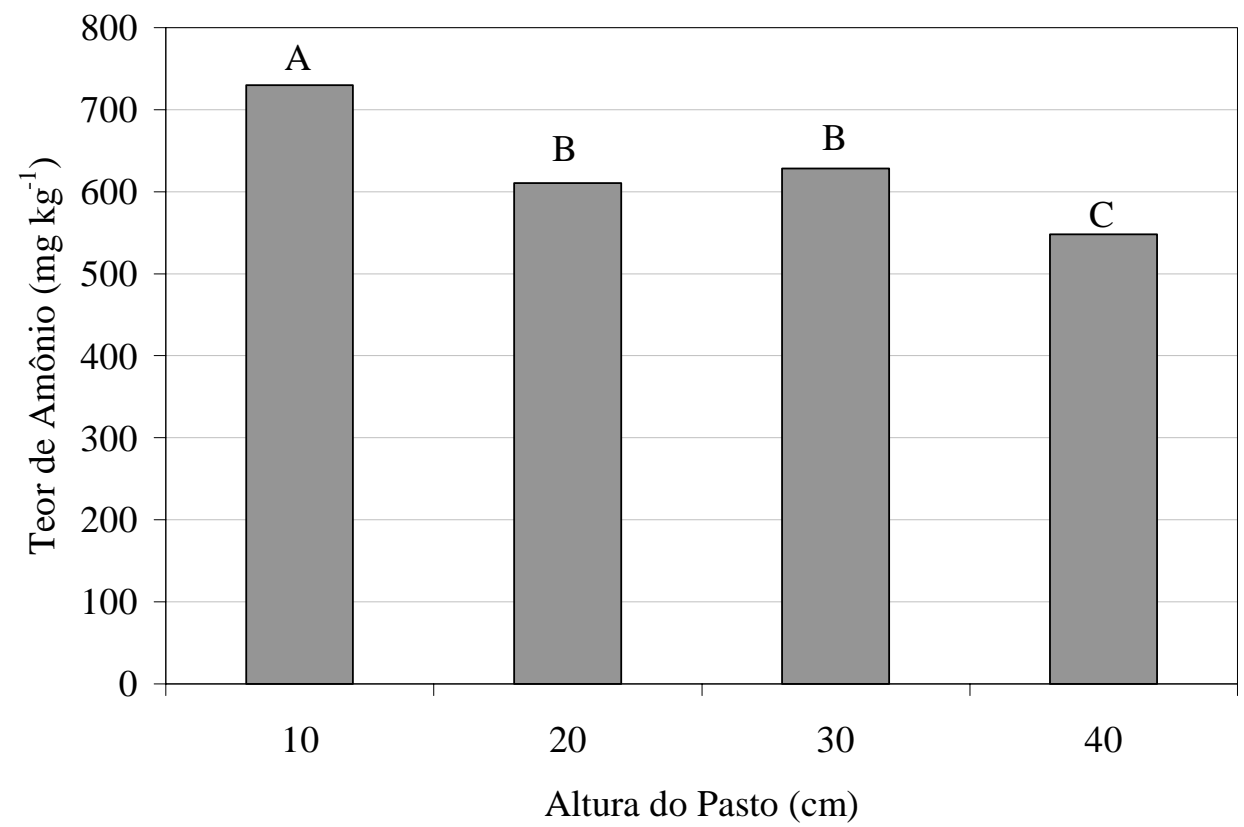

Figura 35 - Teores de amônio em braquiária brizanta mantida em diferentes alturas de pasto.

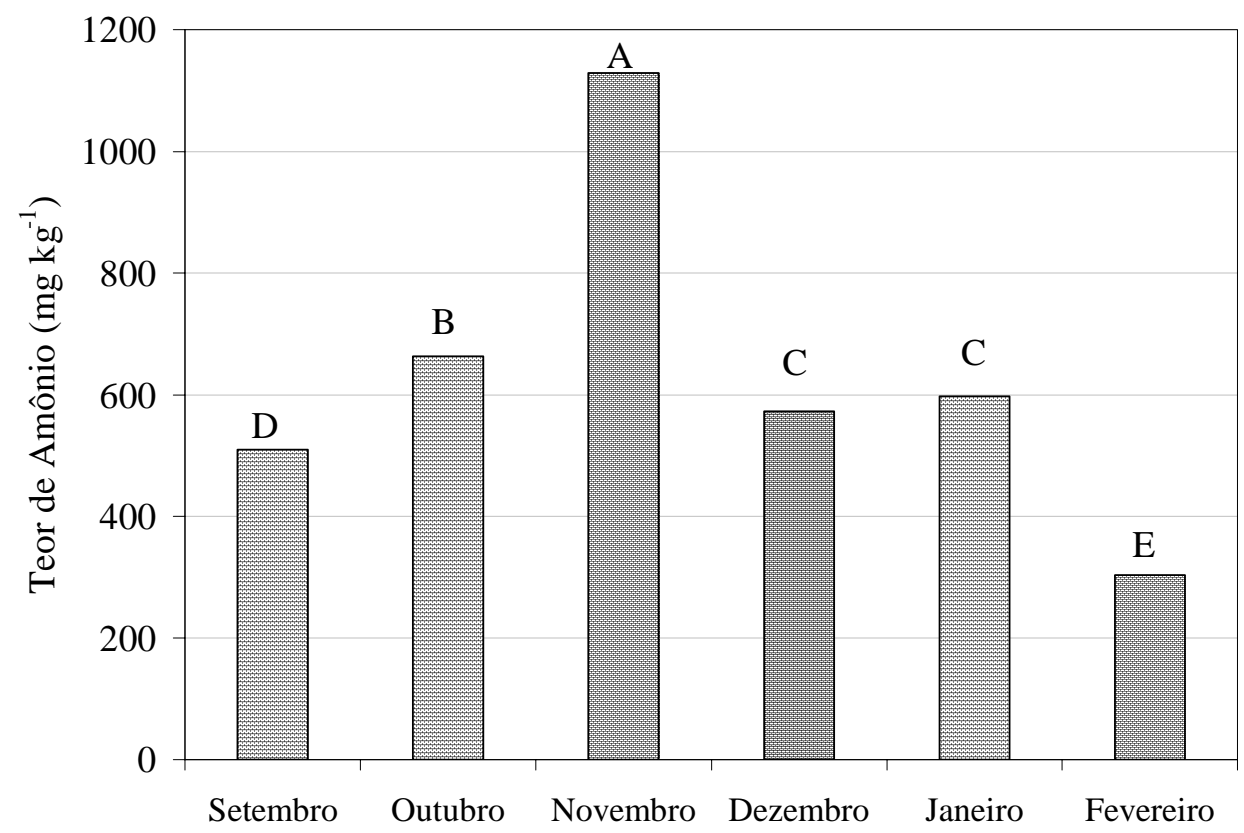

Figura 36 - Teores de amônio em pastos de braquiária brizanta, de setembro de 2001 a fevereiro de 2002. 


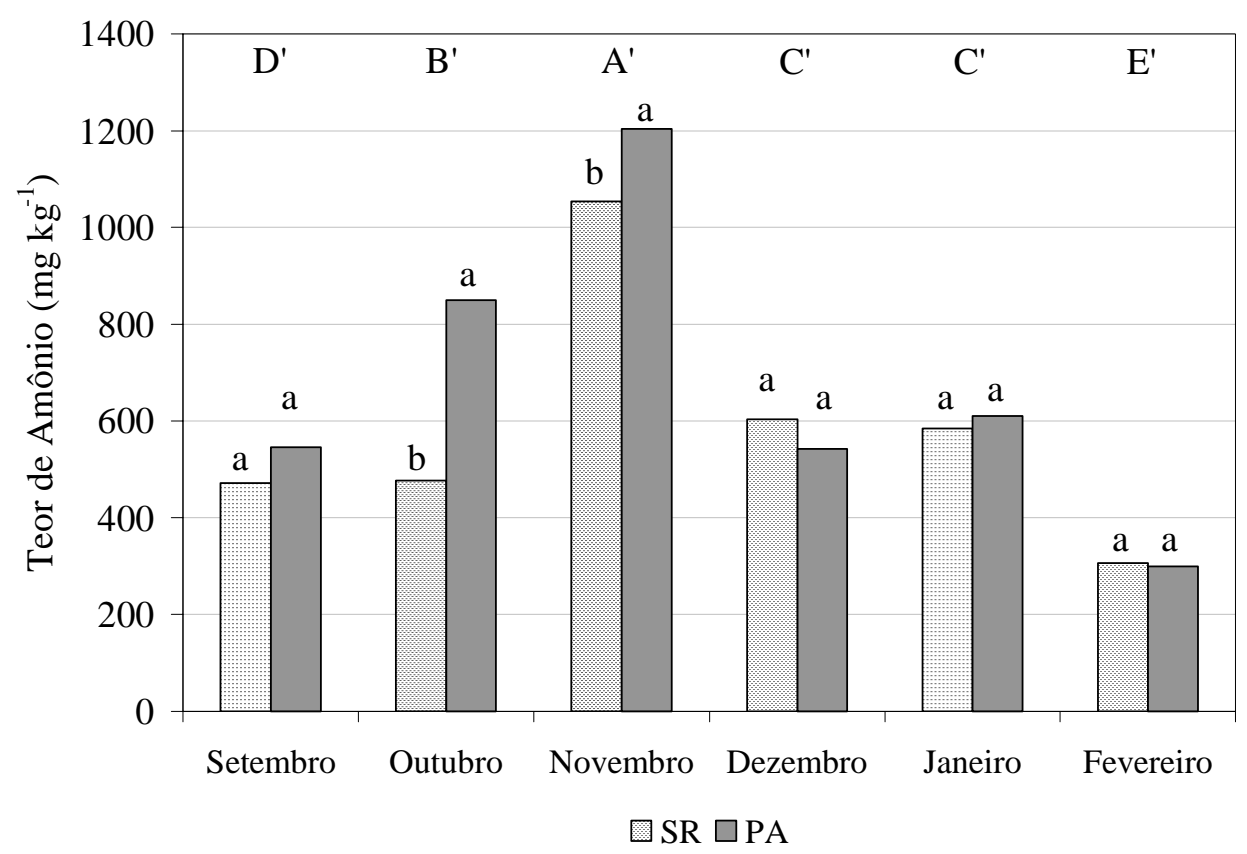

Figura 37 - Teores de amônio no sistema radicular (SR) e na parte aérea (PA) de pastos pastos de braquiária brizanta, de setembro de 2001 a fevereiro de 2002.

médio de amônio relativo à altura de $20 \mathrm{~cm}\left(610,43 \mathrm{mg} \mathrm{kg}^{-1}\right)$ foi semelhante àquele determinado para a altura de $30 \mathrm{~cm}\left(628,10 \mathrm{mg} \mathrm{kg}^{-1}\right)$, ao passo que foi distinto daquele observado para a altura de $40 \mathrm{~cm}\left(547,85 \mathrm{mg} \mathrm{kg}^{-1}\right)$. Os teores médios das alturas de $30 \mathrm{e}$ $40 \mathrm{~cm}$ foram diferentes (Figura 35). Com relação ao mês, o maior teor médio de amônio foi obtido em novembro $\left(1128,5 \mathrm{mg} \mathrm{kg}^{-1}\right)$, sendo que foi diferente de todos os outros meses. O mês de outubro $\left(663,3 \mathrm{mg} \mathrm{kg}^{-1}\right)$ também diferiu dos demais meses, ao passo que os teores determinados em dezembro $\left(572,7 \mathrm{mg} \mathrm{kg}^{-1}\right)$ e janeiro $\left(597,4 \mathrm{mg} \mathrm{kg}^{-1}\right)$ foram semelhantes. Os teores observados em setembro $\left(509,2 \mathrm{mg} \mathrm{kg}^{-1}\right)$ e fevereiro (302,9 $\mathrm{mg} \mathrm{kg}^{-1}$ ) foram distintos (Tabela $17 \mathrm{e}$ Figura 36). No tocante à parte da planta, $\mathrm{o}$ maior valor médio ao longo do período experimental foi observado para a parte aérea $\left(675,02 \mathrm{mg} \mathrm{kg}^{-1}\right)$ em relação ao sistema radicular $\left(582,95 \mathrm{mg} \mathrm{kg}^{-1}\right)$.

$\mathrm{O}$ padrão de comportamento dos teores médios de amônio correspondente às alturas de pasto estudadas foi decrescente ao longo do período experimental, conforme descrito para os teores de $\mathrm{N}$ total e $\mathrm{N}$ solúvel. Embora não seja consensual a hipótese de 
que haja a translocação de amônio das raízes para a parte aérea (Tobin \& Yamaya, 2001; Schjoerring et al., 2002), esse composto é um intermediário central gerado em processos como a redução do nitrato, a fotorrespiração, a degradação de amidas e o catabolismo de proteínas resultante de processos de senescência, bem como tem função chave no metabolismo do nitrogênio em folhas. Nesse sentido, Schjoerring et al. (2002) relataram a existência da translocação do amônio das raízes para a parte aérea, de modo que essa translocação seria motivada pela demanda da parte aérea. Consequentemente, no caso específico deste experimento, o maior teor de amônio deveria ser encontrado na altura de pasto de $10 \mathrm{~cm}$, em função dessa altura apresentar uma menor disponibilidade de esqueletos carbônicos para a formação de novos tecidos (menor teor e estoque de carboidratos). Adicionalmente, devido a maior frequência e intensidade de desfolha em relação às demais condições de pasto estudadas ${ }^{5}$, a translocação dos compostos presentes no sistema radicular para a parte aérea deveria ocorrer de forma mais lenta, considerando-se que esse processo depende diretamente da transpiração da planta, a qual é função direta da quantidade de folhas no dossel associada à atividade metabólica desses órgãos (Taiz \& Zeiger, 1998).

Com relação ao mês, o padrão observado para os teores de amônio foi distinto daqueles até então observados para $\mathrm{N}$ total e $\mathrm{N}$ solúvel, muito embora o amônio faça parte da fração solúvel do nitrogênio na planta. Entre setembro e novembro, foi notado um aumento no teor de amônio, provavelmente devido ao início do verão, época de ocorrência de condições favoráveis à absorção de nitrogênio, principalmente em função do aumento na disponibilidade hídrica no solo (Figura 4), possivelmente associada ao aumento da demanda da planta, resultante do incremento na taxa de acúmulo de forragem do período (Tabela 25).

Ademais, os teores foram praticamente constantes ao longo do período experimental, à exceção dos valores encontrados nos meses de novembro e fevereiro. Em novembro, foi observado um aumento significativo do amônio tanto no sistema

\footnotetext{
${ }^{5}$ GONÇALVES, A.C. (Escola Superior de Agricultura “Luiz de Queiroz”, Piracicaba, SP). Morfogênese, intensidade e frequência de desfolha em pastos de Brachiaria brizantha cv. Marandu. (Dissertação de mestrado em elaboração)
} 
radicular quanto na base do colmo, embora proporcionalmente o acréscimo ocorrido nas raízes tenha sido mais notório (Figura 29). Esse fato mereceu maior atenção, visto que o teor de amônio sofreu um incremento abrupto em relação a outubro e, posteriormente, em dezembro, voltou a cair, mantendo-se constante até janeiro, quando novamente sofreu redução em fevereiro (Figura 28). Aparentemente, esse aumento poderia ser entendido como o resultado de um sinal fisiológico interno cujo objetivo principal teria sido estimular a planta a passar do estádio vegetativo para reprodutivo. Essa indução poderia desencadear um conjunto de alterações em processos bioquímicos e fisiológicos (fenologia), que em última análise, seriam expressos através de alterações morfológicas como o aparecimento de colmos reprodutivo, inflorescências e sementes. No tocante às alterações fisiológicas, poderiam ser citadas as mudanças nas partições de carbono e nitrogênio em virtude de mudanças na priorização de alocação dos assimilados para os drenos metabólicos na planta (Snyder \& Carlson, 1984), de modo que durante o estádio reprodutivo as inflorescências passariam a ser o principal dreno. De forma complementar, é pertinente considerar que durante essa fase de transição ocorre uma produção intensa de hormônios e enzimas responsáveis pelo desencadeamento do processo reprodutivo, que contém nitrogênio em sua composição molecular e é fixado nesses compostos a partir de amônio.

No que diz respeito à parte da planta, o padrão de comportamento observado para os teores de amônio diferiu daquele descrito para os teores de $\mathrm{N}$ solúvel, de modo que nos meses de outubro e novembro, nos quais houve diferenças nos teores de amônio entre as partes da planta, a base do colmo apresentou os maiores valores dessa fração nitrogenada. Esse comportamento estaria indicando a ocorrência de um acúmulo inicial desse composto, que antecederia uma possível translocação do amônio para a parte aérea. 


\subsection{Estoques}

Os resultados referentes aos estoques de amônio são mostrados nas Tabelas 18, 19 e 20 e nas Figuras 38 e 39. Houve efeito de altura ( $\mathrm{P}=0,0022)$, mês $(\mathrm{P}<0,0001)$, parte da planta $(\mathrm{P}<0,0001)$ e das interações altura $\mathrm{x}$ mês $(\mathrm{P}=0,0018)$, altura $\mathrm{x}$ parte da planta $(\mathrm{P}=0,0363)$ e parte da planta $\mathrm{x}$ mês $(\mathrm{P}<0,0001)$, não sendo observada a interação altura $\mathrm{x}$ parte da planta x mês $(\mathrm{P}=0,1010)$. A amplitude dos valores médios dos estoques de amônio durante o período experimental foi de $0,19(20 \mathrm{~cm}$, sistema radicular, fevereiro) a $3,39 \mathrm{~g} \mathrm{~m}^{-2}\left(10 \mathrm{~cm}\right.$, parte aérea, outubro). A altura de pasto de $10 \mathrm{~cm}\left(1,26 \mathrm{~g} \mathrm{~m}^{-2}\right)$ apresentou o maior valor médio de estoque ao longo do experimento e diferiu das demais condições de pasto estudadas (Tabela 18). Os estoques de amônio relativos às alturas de $20\left(0,94 \mathrm{~g} \mathrm{~m}^{-2}\right)$ e $30 \mathrm{~cm}\left(1,01 \mathrm{~g} \mathrm{~m}^{-2}\right)$ foram semelhantes entre si, de modo que somente o valor correspondente à altura de $20 \mathrm{~cm}$ foi distinto do estoque de $40 \mathrm{~cm}(0,81$ $\mathrm{g} \mathrm{m}^{-2}$ ) (Tabela 18). Quanto ao mês, o maior estoque de amônio foi obtido em novembro $\left(1,53 \mathrm{~g} \mathrm{~m}^{-2}\right)$, o qual foi semelhante àquele determinado para outubro $\left(1,43 \mathrm{~g} \mathrm{~m}^{-2}\right)$ (Tabela 18). Ambos diferiram dos estoques encontrados nos demais meses. $\mathrm{O}$ valor obtido em setembro $\left(1,16 \mathrm{~g} \mathrm{~m}^{-2}\right)$ foi diferente daqueles relativos a dezembro $\left(0,78 \mathrm{~g} \mathrm{~m}^{-2}\right)$ e janeiro $\left(0,77 \mathrm{~g} \mathrm{~m}^{-2}\right)$, embora ambos tenham sido semelhantes. O estoque determinado para fevereiro $\left(0,35 \mathrm{~g} \mathrm{~m}^{-2}\right)$ foi o menor durante o período experimental e diferiu dos demais meses. Com relação à parte da planta, o estoque médio correspondente ao sistema radicular $\left(0,60 \mathrm{~g} \mathrm{~m}^{-2}\right)$ foi menor do que aquele obtido para a parte aérea $\left(1,41 \mathrm{~g} \mathrm{~m}^{-2}\right)$ (Tabela 19).

Com relação às alturas de pasto estudadas, o padrão de comportamento dos estoques de amônio foi bastante semelhante ao que foi descrito para $\mathrm{N}$ total e solúvel. Houve redução significativa dos estoques a medida que a altura de pasto aumentou (Figura 38), o que uma vez mais indicaria que a mobilização do amônio para a parte aérea da planta foi mais intensa nas maiores alturas de pasto, devido a maior força de demanda (número de meristemas apicais e crescimento por perfilho) nessas alturas.

No tocante ao mês, o padrão de comportamento dos estoques de amônio foi ligeiramente distinto àqueles observados para os estoques de $\mathrm{N}$ total e solúvel. No 
Tabela 18. Estoques de amônio $\left(\mathrm{g} \mathrm{m}^{-2}\right)$ em braquiária brizanta mantida em diferentes alturas de pasto, de setembro de 2001 a fevereiro de 2002.

\begin{tabular}{|c|c|c|c|c|c|c|c|c|c|c|c|}
\hline \multirow{2}{*}{ Mês } & \multicolumn{8}{|c|}{ Altura do Pasto $(\mathrm{cm})$} & \multirow{2}{*}{\multicolumn{2}{|c|}{ Média }} & \multirow{2}{*}{$\mathrm{EPM}^{*}$} \\
\hline & \multicolumn{2}{|c|}{10} & \multicolumn{2}{|l|}{20} & \multicolumn{2}{|l|}{30} & \multicolumn{2}{|l|}{40} & & & \\
\hline Setembro & 1,08 & $\mathrm{Ba}$ & 1,11 & $\mathrm{Aa}$ & 1,44 & $\mathrm{ABa}$ & 1,03 & $\mathrm{Aa}$ & 1,16 & B' & 0,081 \\
\hline Outubro & 1,93 & $\mathrm{Aa}$ & 1,43 & $\mathrm{Ab}$ & 1,16 & $\mathrm{Bb}$ & 1,22 & $\mathrm{Ab}$ & 1,43 & & 0,099 \\
\hline Novembro & 1,84 & $\mathrm{Aa}$ & 1,14 & $\mathrm{Ab}$ & 1,83 & Aa & 1,33 & $\mathrm{Ab}$ & 1,53 & & 0,110 \\
\hline Dezembro & 1,24 & $\mathrm{Ba}$ & 0,80 & $\mathrm{Bb}$ & 0,64 & $\mathrm{Cbc}$ & 0,42 & $\mathrm{Bc}$ & 0,78 & & 0,056 \\
\hline Janeiro & 1,04 & $\mathrm{Ba}$ & 0,81 & $\mathrm{Bb}$ & 0,71 & $\mathrm{Cbc}$ & 0,51 & $\mathrm{Bc}$ & 0,77 & & 0,051 \\
\hline Fevereiro & 0,42 & $\mathrm{Ca}$ & 0,34 & $\mathrm{Cab}$ & 0,29 & $\mathrm{Db}$ & 0,34 & $\mathrm{Bab}$ & 0,35 & & 0,029 \\
\hline Média & 1,26 & $\mathrm{a}$ & 0,94 & & 1,01 & & 0,81 & & & & \\
\hline $\mathrm{EPM}^{*}$ & 0,053 & & 0,066 & & 0,062 & & 0,062 & & & & \\
\hline
\end{tabular}

*EPM - Erro padrão da média.

Médias na linha seguidas de mesmas letras minúsculas não diferem entre si $(\mathrm{P}>0,10)$.

Médias na coluna seguidas de mesmas letras maiúsculas não diferem entre si $(\mathrm{P}>0,10)$.

Tabela 19. Estoques de amônio $\left(\mathrm{g} \mathrm{m}^{-2}\right)$ no sistema radicular (SR) e na parte aérea (PA) de pastos de braquiária brizanta, de setembro de 2001 a fevereiro de 2002.

\begin{tabular}{|c|c|c|c|c|c|c|}
\hline Mês & SR & & PA & & Média & EPM* $^{*}$ \\
\hline Setembro & 0,65 & $\mathrm{BCb}$ & 1,68 & $\mathrm{Ba}$ & $1,16^{\mathrm{B}}$ & 0,081 \\
\hline Outubro & 0,58 & $\mathrm{Cb}$ & 2,29 & $\mathrm{Aa}$ & $1,43^{\mathrm{A}}$ & 0,099 \\
\hline Novembro & 0,86 & $\mathrm{Ab}$ & 2,21 & $\mathrm{Aa}$ & $1,53 \mathrm{~A}^{\mathrm{\prime}}$ & 0,110 \\
\hline Dezembro & 0,77 & $\mathrm{ABa}$ & 0,79 & $\mathrm{Da}$ & $0,78^{\mathrm{C}}$ & 0,056 \\
\hline Janeiro & 0,55 & $\mathrm{Cb}$ & 0,99 & $\mathrm{Ca}$ & $0,77^{\mathrm{C}}$ & 0,051 \\
\hline Fevereiro & 0,22 & $\mathrm{Db}$ & 0,48 & $\mathrm{Ea}$ & $0,35^{\mathrm{D}}$ & 0,029 \\
\hline Média & 0,60 & $\mathrm{~b}$ & 1,41 & $\mathrm{a}$ & & \\
\hline $\mathrm{EPM}^{*}$ & 0,027 & & 0,055 & & & \\
\hline
\end{tabular}

*EPM - Erro padrão da média.

Médias na linha seguidas de mesmas letras minúsculas não diferem entre si $(\mathrm{P}>0,10)$.

Médias na coluna seguidas de mesmas letras maiúsculas não diferem entre si $(\mathrm{P}>0,10)$. 
Tabela 20. Estoques de amônio $\left(\mathrm{g} \mathrm{m}^{-2}\right)$ no sistema radicular (SR) e na parte aérea (PA) de braquiária brizanta mantida em quatro alturas de pasto.

\begin{tabular}{cccccc}
\hline $\begin{array}{c}\text { Altura do } \\
\text { Pasto }(\mathrm{cm})\end{array}$ & SR & \multicolumn{2}{c}{ PA } & Média & EPM* \\
\hline 10 & $0,71^{\mathrm{Ab}}$ & $1,81^{\mathrm{Aa}}$ & $1,26^{\mathrm{A}}$ & 0,053 \\
20 & $0,66^{\mathrm{Ab}}$ & $1,22^{\mathrm{Ba}}$ & $0,94^{\mathrm{B}^{\prime} \mathrm{C}^{\prime}}$ & 0,066 \\
30 & $0,58^{\mathrm{ABb}}$ & $1,44^{\mathrm{Ba}}$ & $1,01^{\mathrm{B}}$ & 0,062 \\
40 & $0,46^{\mathrm{Bb}}$ & $1,16^{\mathrm{Ba}}$ & $0,81^{\mathrm{C}}$ & 0,062 \\
Média & $0,60^{\mathrm{b}}$ & $1,41^{\mathrm{a}}$ & & \\
EPM* & 0,027 & $0,055^{*}$ & & \\
\hline
\end{tabular}

*EPM - Erro padrão da média.

Médias na linha seguidas de mesmas letras minúsculas não diferem entre si $(\mathrm{P}>0,10)$.

Médias na coluna seguidas de mesmas letras maiúsculas não diferem entre si $(\mathrm{P}>0,10)$.

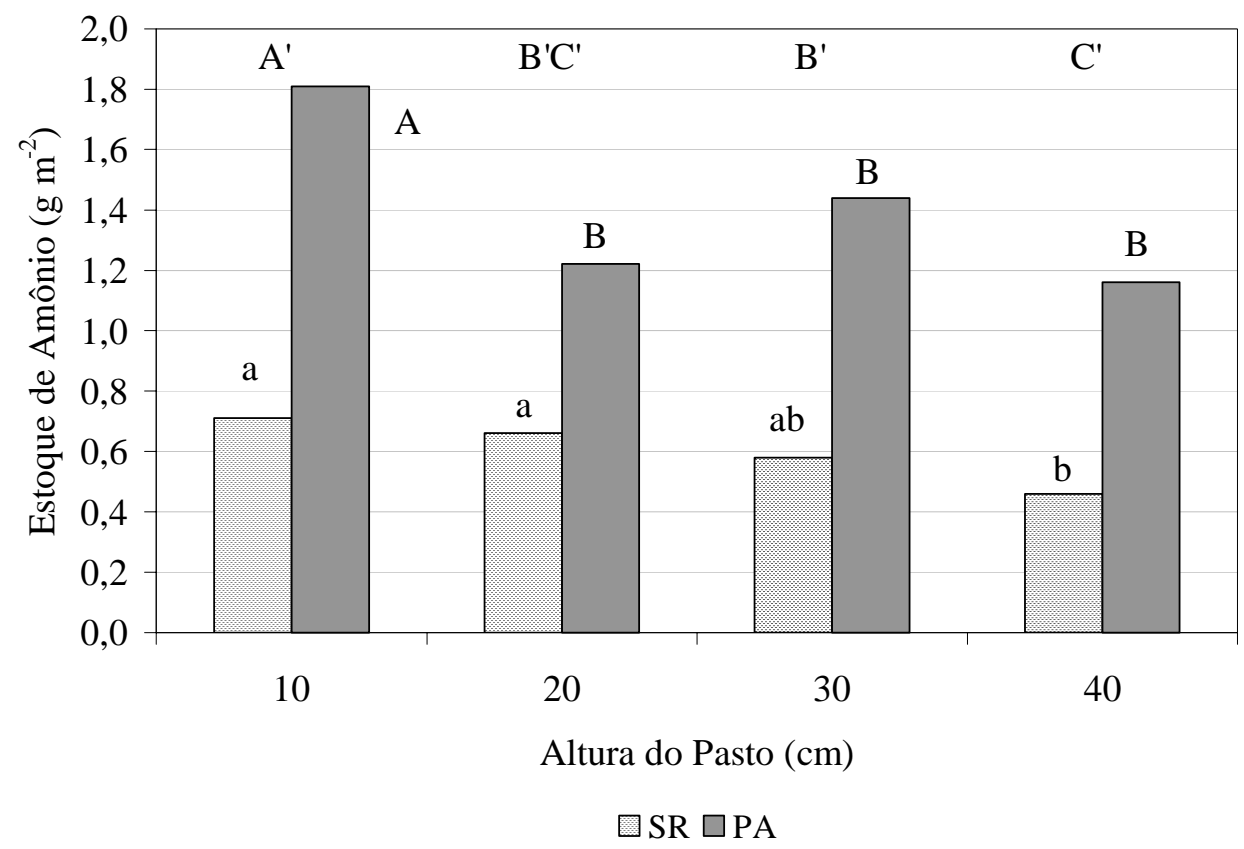

Figura 38 - Estoques de amônio no sistema radicular (SR) e na parte aérea (PA) de braquiária brizanta mantida em diferentes alturas de pasto. 


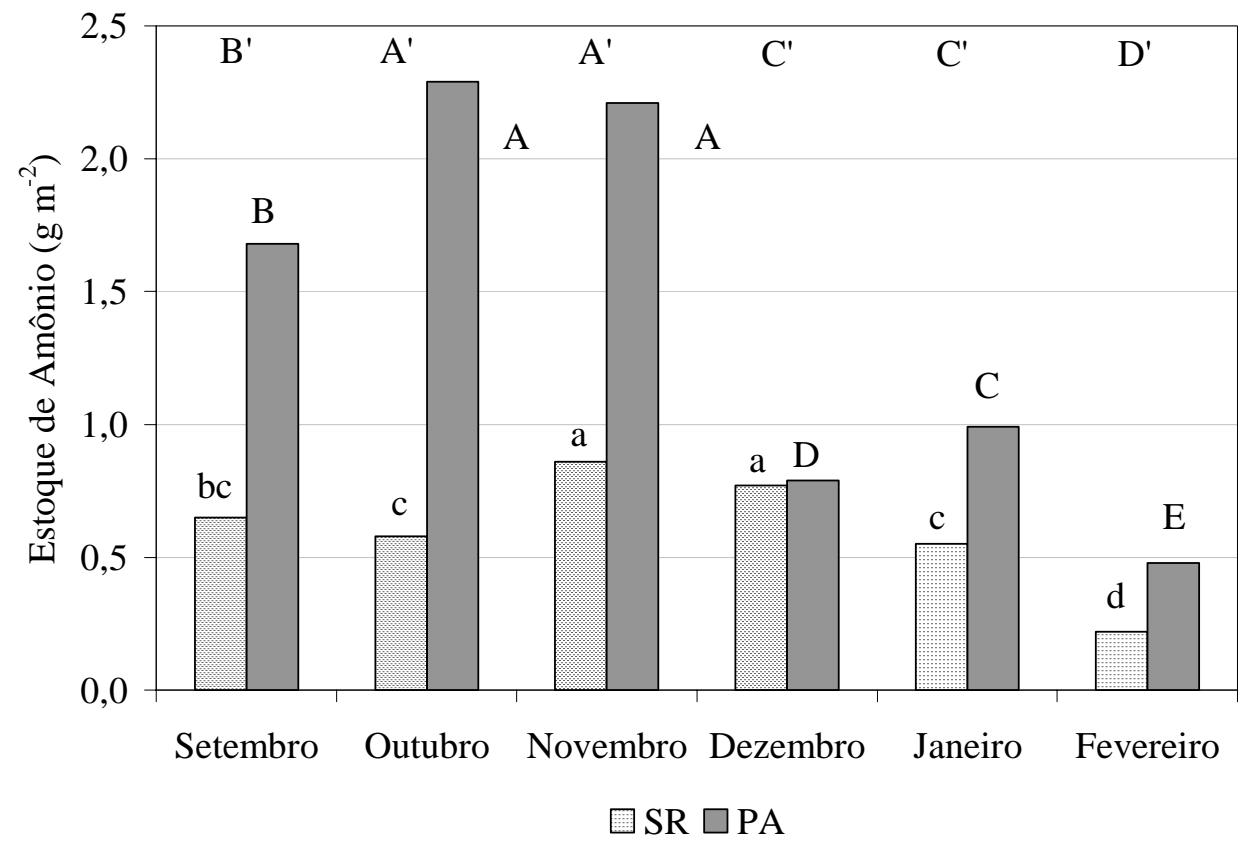

Figura 39 - Estoques de amônio no sistema radicular (SR) e na parte aérea (PA) de pastos de braquiária brizanta de setembro de 2001 a fevereiro de 2002.

entanto, foi semelhante ao relatado para os teores de amônio. Houve um aumento entre os meses de setembro e novembro, provavelmente devido ao início do verão, que devido ao aumento da precipitação gerou uma condição favorável à absorção de nitrogênio e, em seguida, com a transição do estádio vegetativo para o reprodutivo, mostrou uma queda acentuada entre novembro e fevereiro. $\mathrm{O}$ valor máximo encontrado em novembro parecer ratificar a hipótese levantada na seção anterior relativa à associação entre o início do processo de indução reprodutiva com o aumento no acúmulo de amônio para satisfazer a demanda de compostos (hormônios e enzimas) que seriam utilizados antes (indução) e durante esse estádio de desenvolvimento.

Com relação à parte da planta, foi observado que os maiores estoques de amônio foram encontrados consistentemente na parte aérea, de modo que somente em dezembro não houve diferença entre as partes (Figura 39). Mais uma vez, esse fato estaria indicando que há uma mobilização do sistema radicular para a parte aérea e, em seguida, esse composto seria transportado para as folhas e/ou inflorescências. As maiores variações me estoque foram observadas para a parte aérea relativamente ao sistema 
radicular, fato este consistente com o comportamento observado para $\mathrm{N}$ total e $\mathrm{N}$ solúvel.

\subsubsection{Nitrato $\left(\mathrm{NO}_{3}{ }^{-}\right)$}

\subsection{Teores}

Os resultados referentes aos teores de nitrato são mostrados na Tabela 21 e nas Figuras 40 e 41 . Houve efeito de mês $(\mathrm{P}<0,0001)$, parte da planta $(\mathrm{P}=0,0017)$ e das interações parte da planta x mês $(\mathrm{P}<0,0001)$ e altura x parte da planta x mês $(\mathrm{P}=0,0950)$. A amplitude dos teores de nitrato durante o período experimental foi de 51,3 $(40 \mathrm{~cm}$, sistema radicular, setembro) a 260,1 $\mathrm{mg} \mathrm{kg}^{-1}$ (10 cm, parte aérea, outubro) (Tabela 21). O maior teor médio de nitrato encontrado durante o período experimental foi relativo ao mês de outubro (155,4 $\mathrm{mg} \mathrm{kg}^{-1}$ ), que não diferiu do teor observado em janeiro (141,6 $\mathrm{mg} \mathrm{kg}^{-1}$ ). Ambos diferiram dos demais meses. Os teores médios determinados para novembro (119,8 $\left.\mathrm{mg} \mathrm{kg}^{-1}\right)$ e dezembro $\left(116,3 \mathrm{mg} \mathrm{kg}^{-1}\right)$ também foram semelhantes. $\mathrm{O}$ teor relativo a dezembro não diferiu daquele encontrado para setembro $\left(103,8 \mathrm{mg} \mathrm{kg}^{-1}\right)$ que, por sua vez, não diferiu do teor observado em fevereiro $\left(98,1 \mathrm{mg} \mathrm{kg}^{-1}\right)$, que uma vez mais foi o menor durante o experimento. Com relação à parte da planta, o menor teor foi encontrado no sistema radicular $\left(114,0 \mathrm{mg} \mathrm{kg}^{-1}\right)$, o qual diferiu daquele determinado para a parte aérea $\left(131,0 \mathrm{mg} \mathrm{kg}^{-1}\right)$.

Embora tenha sido detectada diferença entre os teores médios de nitrato durante o experimento (Tabela 21), esses teores não assumiram nenhum padrão específico de comportamento no período (Figura 40). Os teores sofreram um aumento no mês de outubro, provavelmente em decorrência do início da estação de verão, quando a disponibilidade hídrica no solo foi incrementada por precipitações, associado a possibilidade de que no momento da avaliação os íons nitrato $\left(\mathrm{NO}_{3}{ }^{-}\right)$ainda não haviam sido assimilados internamente através de formas reduzidas $\left(\mathrm{NH}_{4}{ }^{+}, \mathrm{NH}_{3}, \mathrm{R}_{-} \mathrm{NH}_{\mathrm{n}}\right)$ que, em última análise, são as formas pelas quais a planta incorpora o nitrogênio nos tecidos vegetais. 
Tabela 21. Teores de nitrato $\left(\mathrm{mg} \mathrm{kg}^{-1}\right)$ no sistema radicular (SR) e na parte aérea (PA) de braquiária brizanta mantida em quatro alturas de pasto, de setembro de 2001 a fevereiro de 2002.

\begin{tabular}{|c|c|c|c|c|c|c|c|c|}
\hline \multirow{2}{*}{$\begin{array}{l}\text { Altura do } \\
\text { Pasto }(\mathrm{cm})\end{array}$} & \multicolumn{5}{|c|}{ Parte da Planta } & \multirow{2}{*}{\multicolumn{2}{|c|}{ Média }} & \multirow{2}{*}{$\begin{array}{c}\text { Média } \\
\text { do Mês }\end{array}$} \\
\hline & \multicolumn{3}{|c|}{ SR } & \multicolumn{2}{|c|}{ PA } & & & \\
\hline \multicolumn{9}{|c|}{ Setembro - 2001} \\
\hline 10 & 93,0 & & $(16,47)$ & 156,7 & $(18,58)$ & 124,9 & $(12,95)$ & \\
\hline 20 & 68,4 & & $(16,94)$ & 143,4 & $(18,69)$ & 105,9 & $(13,24)$ & $103,8^{\text {CD' }}$ \\
\hline 30 & 66,1 & & $(17,08)$ & 144,2 & $(18,66)$ & 105,1 & $(13,07)$ & \\
\hline 40 & 51,3 & & $(16,94)$ & 106,9 & $(18,69)$ & 79,1 & $(13,24)$ & $(0,56)$ \\
\hline Média & 69,7 & $\mathrm{~b}$ & $(8,43)$ & $137,8^{a}$ & $(9,33)$ & & & \\
\hline \multicolumn{9}{|c|}{ Outubro - 2001} \\
\hline 10 & 65,7 & & $(18,25)$ & 260,1 & $(21,37)$ & 162,9 & $(14,52)$ & \multirow{5}{*}{$\begin{array}{r}155,4^{A^{\prime}} \\
(7,05)\end{array}$} \\
\hline 20 & 115,4 & & $(18,26)$ & 202,4 & $(18,74)$ & 158,9 & $(13,66)$ & \\
\hline 30 & 79,3 & & $(18,36)$ & 222,7 & $(21,44)$ & 151,0 & $(14,59)$ & \\
\hline 40 & 70,5 & & $(18,26)$ & 227,1 & $(18,74)$ & 148,8 & $(13,66)$ & \\
\hline Média & 82,7 & $\mathrm{~b}$ & $(9,14)$ & 228,1 a & $(10,05)$ & & & \\
\hline \multicolumn{9}{|c|}{ Novembro - 2001} \\
\hline 10 & 165,1 & & $(18,30)$ & 79,3 & $(18,52)$ & 122,2 & $(13,41)$ & \multirow{5}{*}{$\begin{array}{c}119,8^{\mathrm{B}^{\prime}} \\
(7,06)\end{array}$} \\
\hline 20 & 99,5 & & $(20,99)$ & 97,6 & $(18,73)$ & 98,5 & $(14,62)$ & \\
\hline 30 & 165,7 & & $(18,65)$ & 102,6 & $(18,63)$ & 134,1 & $(13,77)$ & \\
\hline 40 & 132,1 & & $(20,99)$ & 116,7 & $(18,73)$ & 124,4 & $(14,62)$ & \\
\hline Média & 140,6 & $\mathrm{a}$ & $(9,88)$ & $99,0 \mathrm{~b}$ & $(9,33)$ & & & \\
\hline \multicolumn{9}{|c|}{ Dezembro - 2001} \\
\hline 10 & 160,8 & & $(21,26)$ & 90,6 & $(18,35)$ & 125,7 & $(14,65)$ & \multirow{5}{*}{$\begin{array}{c}116,3^{\mathrm{BC}} \\
(7,01)\end{array}$} \\
\hline 20 & 147,0 & & $(18,71)$ & 81,1 & $(18,65)$ & 114,1 & $(13,82)$ & \\
\hline 30 & 140,8 & & $(18,67)$ & 117,1 & $(18,54)$ & 128,9 & $(13,75)$ & \\
\hline 40 & 116,0 & & $(18,70)$ & 77,3 & $(18,65)$ & 96,6 & $(13,82)$ & \\
\hline Média & 141,1 & $\mathrm{a}$ & $(9,68)$ & $91,5 \mathrm{~b}$ & $(9,27)$ & & & \\
\hline \multicolumn{9}{|c|}{ Janeiro - 2002} \\
\hline 10 & 128,8 & & $(21,32)$ & 160,9 & $(20,54)$ & 144,9 & $(15,22)$ & \multirow{5}{*}{$\begin{array}{c}141,6^{A^{\prime}} \\
(7,03)\end{array}$} \\
\hline 20 & 149,7 & & $(18,72)$ & 147,9 & $(18,36)$ & 148,8 & $(13,69)$ & \\
\hline 30 & 144,0 & & $(18,68)$ & 155,5 & $(18,26)$ & 149,8 & $(13,62)$ & \\
\hline 40 & 134,6 & & $(18,72)$ & 111,6 & $(18,36)$ & 123,1 & $(13,69)$ & \\
\hline Média & 139,3 & $\mathrm{a}$ & $(9,70)$ & $144,0^{\mathrm{a}}$ & $(9,45)$ & & & \\
\hline \multicolumn{9}{|c|}{ Fevereiro - 2002} \\
\hline 10 & 122,2 & & $(18,59)$ & 112,4 & $(16,44)$ & 117,3 & $(12,57)$ & \multirow{5}{*}{$\begin{array}{l}98,1^{D^{\prime}} \\
(6,50)\end{array}$} \\
\hline 20 & 107,8 & & $(18,68)$ & 88,4 & $(17,22)$ & 98,1 & $(13,09)$ & \\
\hline 30 & 107,8 & & $(18,67)$ & 70,5 & $(17,01)$ & 89,1 & $(13,24)$ & \\
\hline 40 & 104,4 & & $(18,68)$ & 71,5 & $(17,22)$ & 88,0 & $(13,09)$ & \\
\hline Média & 110,5 & $\mathrm{a}$ & $(9,33)$ & $85,7^{b}$ & $(8,49)$ & & & \\
\hline
\end{tabular}

Valores entre parênteses indicam o Erro Padrão da Média (EPM).

Médias na linha seguidas de mesmas letras minúsculas não diferem entre si $(\mathrm{P}>0,10)$.

Médias na coluna seguidas de mesmas letras maiúsculas não diferem entre si $(P>0,10)$. 


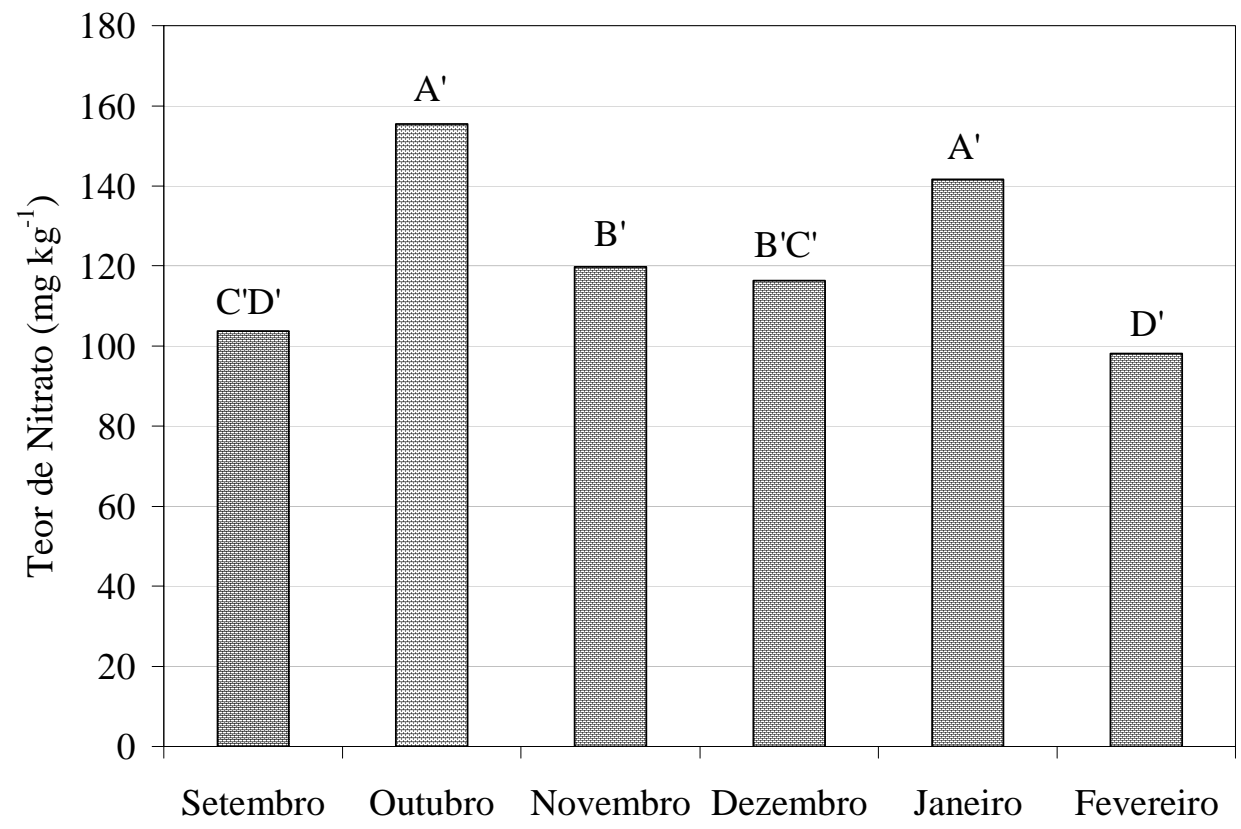

Figura 40 - Teores de nitrato em pastos de braquiária brizanta, de setembro de 2001 a fevereiro de 2002.

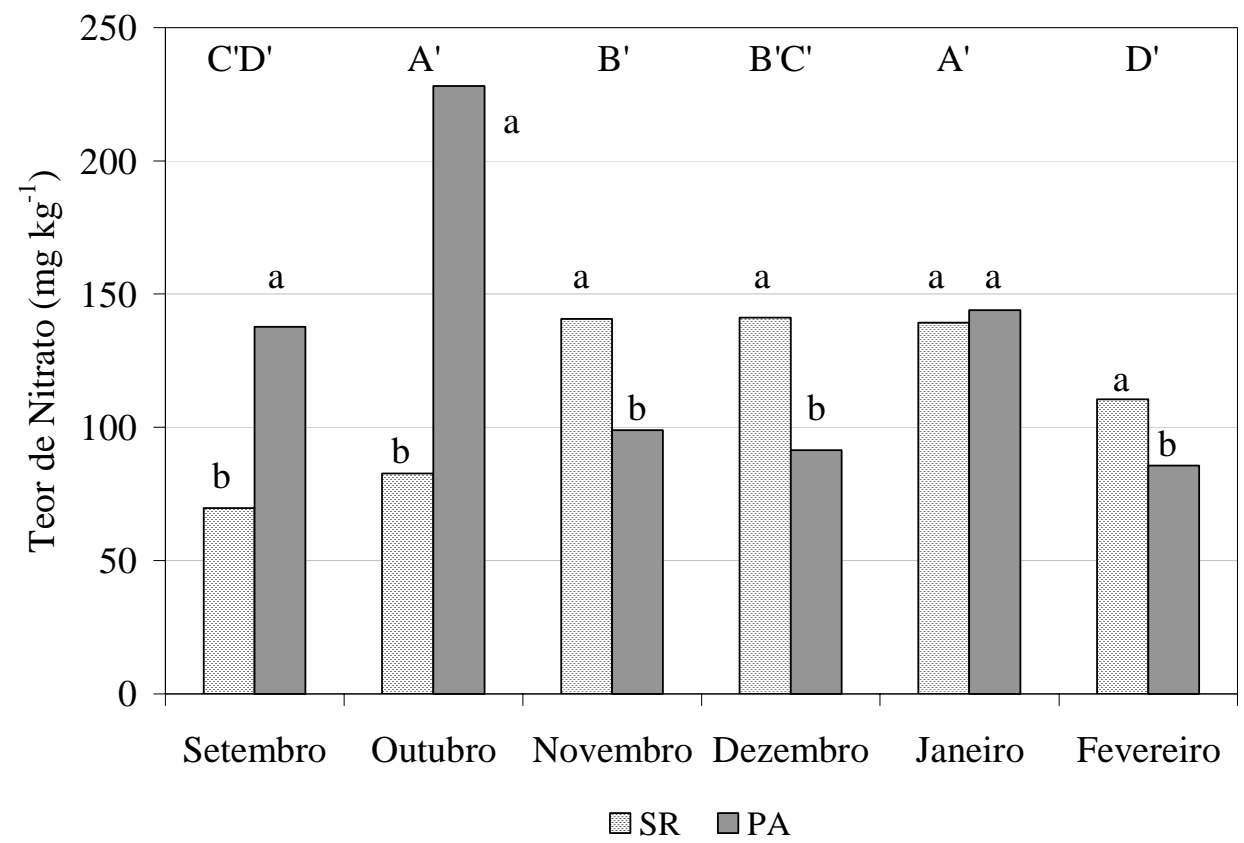

Figura 41 - Teores de nitrato no sistema radicular (SR) e na parte aérea (PA) em pastos de braquiária brizanta, de setembro de 2001 a fevereiro de 2002. 
A partir de outubro, seria esperado um aumento na absorção de nitrato em função das condições favoráveis de disponibilidade de água no solo, visto que essa é a principal forma de nitrogênio encontrada nos solos sem limitações de drenagem (ambiente oxidante). Esse aumento ocorreria como consequência da necessidade de incorporação de nitrogênio em esqueletos carbônicos para a formação de compostos orgânicos que atuariam na gênese de tecidos (aminoácidos, enzimas, proteínas, etc.), consoante com o aumento da taxa de acúmulo de forragem entre outubro e janeiro. Deve ser considerado que em novembro, ao contrário do que havia sido constatado para os teores e estoques de amônio, não foram observados aumentos nos teores de nitrato.

O aumento observado no mês de janeiro poderia estar associado com a redução na disponibilidade de carbono para a formação de novos tecidos também observada nesse mês, visto que um importante fator associado à absorção e assimilação do nitrogênio na planta é o estoque de carboidratos disponível na planta (Engels \& Marschner, 1995). Essa redução no estoque de carboidratos (Tabela 8) deve ter estado provavelmente associada ao aumento observado em IAF (Tabela 4), que em novembro alcançou o maior valor durante o período experimental. Adicionalmente, se o estoque de carboidratos não é suficiente para fixar todo o nitrogênio absorvido, a planta lança mão do armazenamento desse elemento, que em condições de balanço positivo de energia é feito sob as formas de aminoácidos, amidas e proteínas e, no caso de limitação de energia, o nitrogênio pode ser armazenado temporariamente sob a forma de nitrato (Engels \& Marschner, 1995). O maior teor de nitrato em janeiro poderia, portanto, ser o resultado da não transformação desse íon em amônio, decorrente da pequena disponibilidade de energia na planta motivada pelo baixo estoque de carboidratos não estruturais, acarretado, possivelmente, pela maior produção de área foliar (IAF) e início do estádio reprodutivo de desenvolvimento.

Ainda no mês de novembro, foi observada uma redução acentuada no teor de nitrato nos órgãos de reserva (Figura 40) e, como consequência, notou-se uma alteração marcante na relação amônio/nitrato que variou entre 3 e 5 de setembro a fevereiro e, passou 9 em novembro (Figura 42). Tal redução observada para o nitrato poderia indicar novamente a ação do metil jasmonato, que atuaria modificando a partição de frações 
nitrogenadas na planta, de modo que essa redução poderia ser resultante de maior mobilização de nitrato para as folhas, ou mesmo da inibição da absorção desse íon (Rossato et al., 2002 b). Por outro lado, em fevereiro foi notada uma redução nesse teor, que embora tenha sido significativa, não diferiu do que já havia sido apresentado para as outras frações nitrogenadas e, provavelmente, estaria associada com o estádio reprodutivo da brizanta, marcadamente pela demanda metabólica das inflorescências.

Quanto à parte da planta, embora os estoques relativos à parte aérea tenham sido superiores àqueles determinados para o sistema radicular, foi observada uma transição de importância entre as partes. Em setembro e outubro, o maior teor de nitrato na parte aérea se destacou em relação ao sistema radicular. No entanto, a partir de novembro, os teores de nitrato foram consistentemente maiores no sistema radicular. Esse fato poderia estar indicando que o nitrato foi acumulado na parte aérea enquanto não havia condições favoráveis para sua assimilação em compostos orgânicos de maior massa molecular que atuariam no processo de crescimento, visto que a taxa de acúmulo de forragem deve ter sido reduzida nessa época. A partir de novembro, com o incremento na taxa de acúmulo

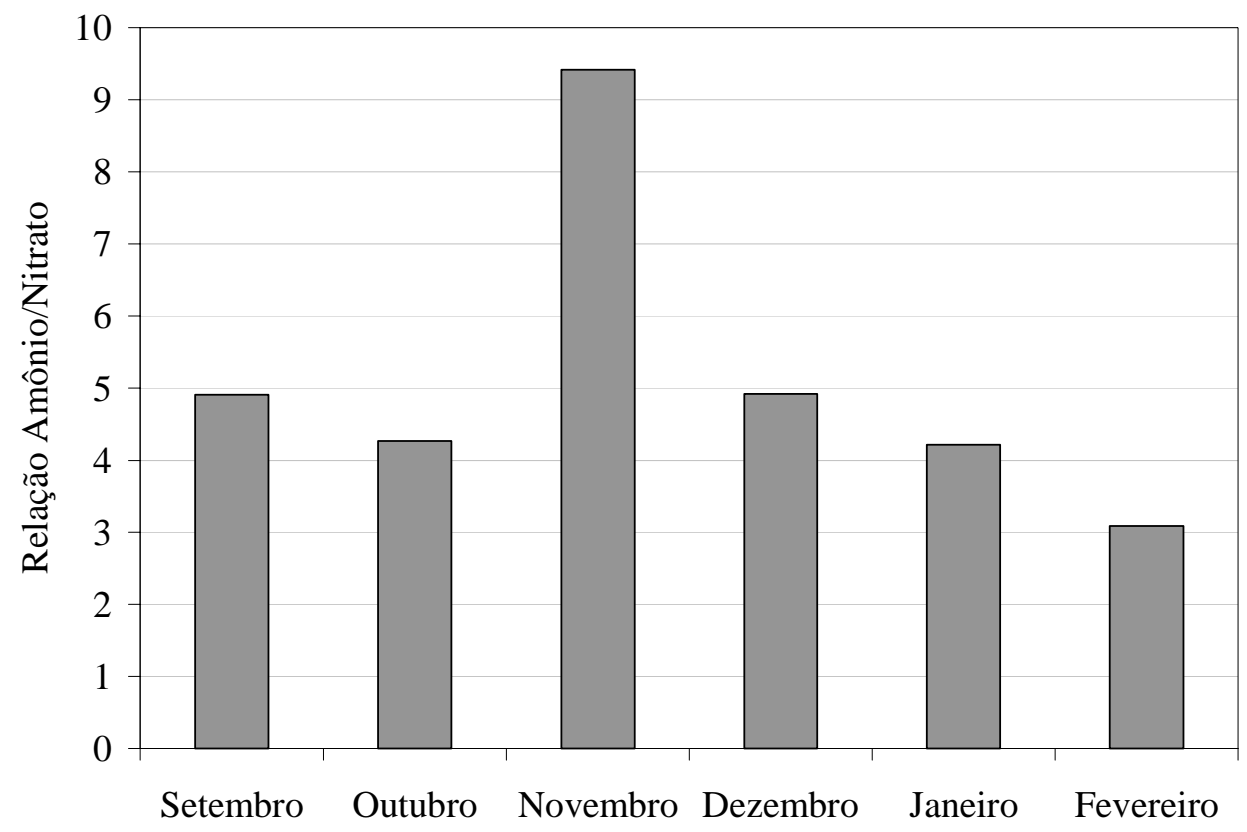

Figura 42 - Relação amônio/nitrato (teores) em pastos de braquiária brizanta, de setembro de 2001 a fevereiro de 2002. 
de forragem, provavelmente o nitrato que se encontrava acumulado na parte aérea foi rapidamente convertido em amônio e, em seguida, passou a integrar compostos como aminoácidos, amidas, enzimas, hormônios, pigmentos, proteínas, etc, fato este corroborado pela elevação nos teores de amônio. Em fevereiro foi observado o menor teor de nitrato de todo o período experimental, reforçando o padrão sugerido das modificações fisiológicas que devem ocorrer na planta durante seu estádio de desenvolvimento reprodutivo.

\subsection{Estoques}

Os resultados referentes aos estoques de nitrato são apresentados nas Tabelas 22 e 23 e nas Figuras 43 e 44. Houve efeito de altura ( $\mathrm{P}=0,0440)$, mês $(\mathrm{P}<0,0001)$, parte da planta $(\mathrm{P}<0,0001)$ e da interação parte da planta x mês $(\mathrm{P}<0,0001)$. A amplitude dos valores médios de estoque de nitrato ao longo do período experimental foi de $0,06 \mathrm{~g} \mathrm{~m}^{-2}$ (20 cm, sistema radicular, fevereiro) a $0,81 \mathrm{~g} \mathrm{~m}^{-2}(10 \mathrm{~cm}$, parte aérea, outubro). A altura de pasto de $10 \mathrm{~cm}\left(0,25 \mathrm{~g} \mathrm{~m}^{-2}\right)$ revelou o maior valor médio de estoque durante o experimento, o qual somente diferiu do estoque relativo à altura de pasto de $40 \mathrm{~cm}(0,16$ $\mathrm{g} \mathrm{m}^{-2}$ ) (Tabela 22). Os estoques correspondentes às alturas de $20\left(0,22 \mathrm{~g} \mathrm{~m}^{-2}\right)$ e $30 \mathrm{~cm}$ $\left(0,21 \mathrm{~g} \mathrm{~m}^{-2}\right)$ foram semelhantes entre si, embora diferiram da altura de $40 \mathrm{~cm}(0,16$ $\left.\mathrm{g} \mathrm{m}^{-2}\right)$. Com relação ao mês, o maior estoque de nitrato foi observado em outubro $(0,40$ $\mathrm{g} \mathrm{m}^{-2}$ ), o qual foi distinto dos demais meses estudados (Tabelas 22 e Figura 44) . O estoque relativo ao mês de setembro $\left(0,27 \mathrm{~g} \mathrm{~m}^{-2}\right)$ diferiu dos outros meses, sendo o segundo maior estoque encontrado. Na sequiência apareceu o estoque de janeiro $(0,19 \mathrm{~g}$ $\mathrm{m}^{-2}$ ), que foi diferente dos estoques correspondentes aos meses de novembro, dezembro e fevereiro. Os estoques de novembro $\left(0,15 \mathrm{~g} \mathrm{~m}^{-2}\right)$ e dezembro $\left(0,16 \mathrm{~g} \mathrm{~m}^{-2}\right)$ foram semelhantes, do mesmo modo que foi observado para novembro $\left(0,15 \mathrm{~g} \mathrm{~m}^{-2}\right)$ e fevereiro $\left(0,11 \mathrm{~g} \mathrm{~m}^{-2}\right)$. No tocante à parte da planta, o estoque médio relativo ao sistema radicular $\left(0,11 \mathrm{~g} \mathrm{~m}^{-2}\right)$ foi menor do que aquele observado para a parte aérea $\left(0,31 \mathrm{~g} \mathrm{~m}^{-2}\right)$ (Tabela 23). 
Tabela 22. Estoques de nitrato $\left(\mathrm{g} \mathrm{m}^{-2}\right)$ em braquiária brizanta mantida em diferentes alturas de pasto, de setembro de 2001 a fevereiro de 2002.

\begin{tabular}{|c|c|c|c|c|c|c|}
\hline \multirow{2}{*}{ Mês } & \multicolumn{4}{|c|}{ Altura do Pasto $(\mathrm{cm})$} & \multirow{2}{*}{ Média } & \multirow{2}{*}{$\mathrm{EPM}^{*}$} \\
\hline & 10 & 20 & 30 & 40 & & \\
\hline Setembro & 0,28 & 0,26 & 0,33 & 0,19 & $0,27^{\mathrm{B}^{\prime}}$ & 0,020 \\
\hline Outubro & 0,44 & 0,44 & 0,40 & 0,33 & $0,40^{A^{\prime}}$ & 0,024 \\
\hline Novembro & 0,18 & 0,15 & 0,15 & 0,14 & $0,15^{\text {D'E' }}$ & 0,019 \\
\hline Dezembro & 0,26 & 0,17 & 0,14 & 0,09 & $0,16^{\mathrm{D}^{\prime}}$ & 0,015 \\
\hline Janeiro & 0,23 & 0,22 & 0,18 & 0,14 & $0,19^{\mathrm{C}}$ & 0,013 \\
\hline Fevereiro & 0,14 & 0,12 & 0,09 & 0,10 & $0,11^{\mathrm{E}}$ & 0,016 \\
\hline Média & $0,25^{\mathrm{a}}$ & $0,22^{\mathrm{a}}$ & $0,21^{\mathrm{a}}$ & $0,16^{\mathrm{b}}$ & & \\
\hline EPM* $^{*}$ & 0,018 & 0,014 & 0,016 & 0,016 & & \\
\hline
\end{tabular}

*EPM - Erro padrão da média.

Médias na linha seguidas de mesmas letras minúsculas não diferem entre si $(\mathrm{P}>0,10)$.

Médias na coluna seguidas de mesmas letras maiúsculas não diferem entre si $(\mathrm{P}>0,10)$.

Tabela 23. Estoques de nitrato $\left(\mathrm{g} \mathrm{m}^{-2}\right)$ no sistema radicular (SR) e na parte aérea (PA) de pastos de braquiária brizanta, de setembro de 2001 a fevereiro de 2002.

\begin{tabular}{|c|c|c|c|c|}
\hline Mês & SR & PA & Média & $\mathrm{EPM}^{*}$ \\
\hline Setembro & $0,09^{\mathrm{Cb}}$ & $0,44^{\mathrm{Ba}}$ & $0,27^{\mathrm{B}^{\prime}}$ & 0,020 \\
\hline Outubro & $0,10^{\mathrm{BCb}}$ & $0,70^{\mathrm{Aa}}$ & $0,40^{\mathrm{A}^{\prime}}$ & 0,024 \\
\hline Novembro & $0,12^{\mathrm{BCa}}$ & $0,18^{\mathrm{Da}}$ & $0,15^{D^{\prime} E^{\prime}}$ & 0,019 \\
\hline Dezembro & 0,17 Аa & $0,15^{\mathrm{Da}}$ & $0,16^{\text {D' }}$ & 0,015 \\
\hline Janeiro & $0,13^{\mathrm{Bb}}$ & $0,26^{\mathrm{Ca}}$ & $0,19^{\mathrm{C}}$ & 0,013 \\
\hline Fevereiro & $0,08^{\mathrm{Cb}}$ & $0,15^{\mathrm{Da}}$ & $0,11^{\mathrm{E}}$ & 0,016 \\
\hline Média & $0,11^{\mathrm{b}}$ & $0,31^{\mathrm{a}}$ & & \\
\hline $\mathrm{EPM}^{*}$ & 0,008 & 0,015 & & \\
\hline
\end{tabular}

*EPM - Erro padrão da média.

Médias na linha seguidas de mesmas letras minúsculas não diferem entre si $(\mathrm{P}>0,10)$.

Médias na coluna seguidas de mesmas letras maiúsculas não diferem entre si $(\mathrm{P}>0,10)$. 


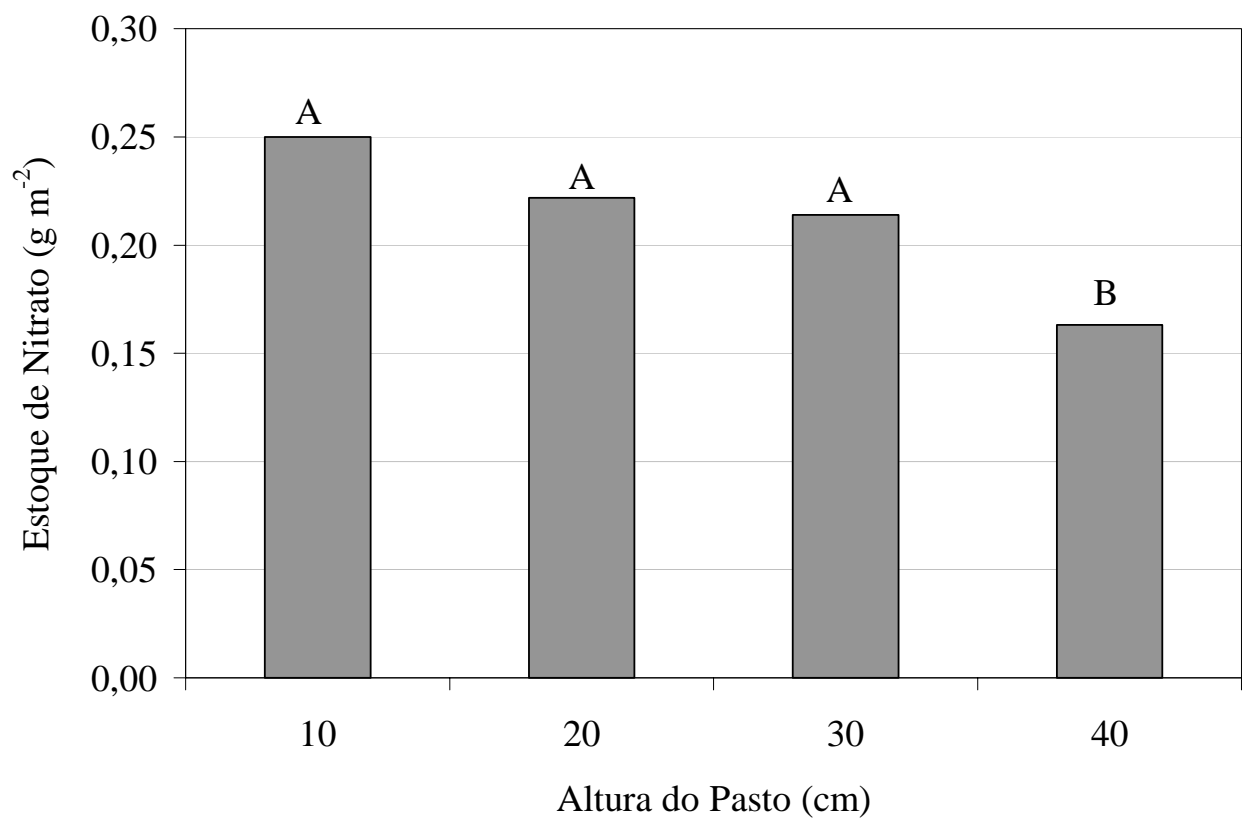

Figura 43 - Estoques de nitrato em braquiária brizanta mantida em diferentes alturas de pasto.

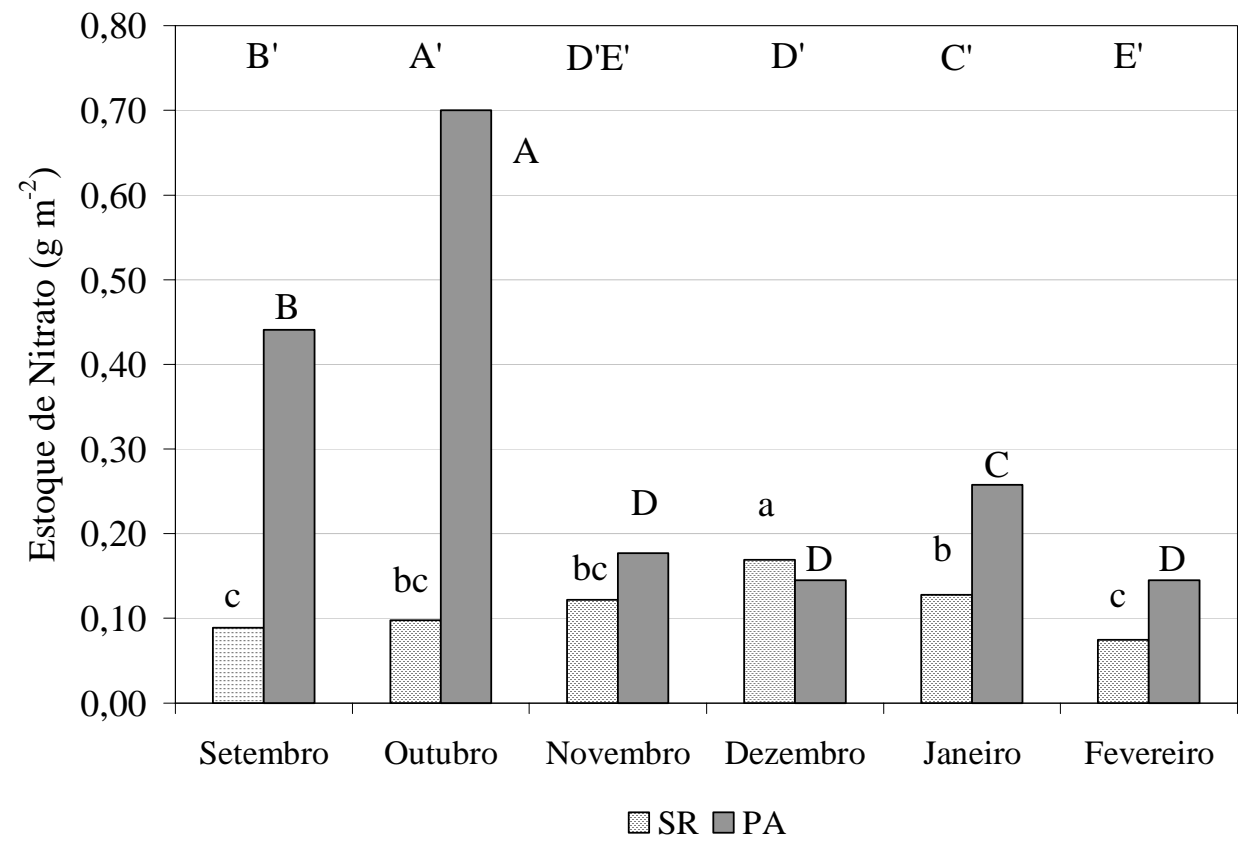

Figura 44 - Estoques de nitrato no sistema radicular (SR) e na parte aérea (PA) de pastos de braquiária brizanta, de setembro de 2001 a fevereiro de 2002. 
O padrão de comportamento apresentado pelas alturas de pasto estudadas foi, uma vez mais, decrescente, de modo análogo ao que havia sido descrito para os estoques de $\mathrm{N}$ total, $\mathrm{N}$ solúvel e amônio. Esse fato estaria indicando que a ocorrência de mobilização do nitrato para a parte aérea da planta foi mais intensa nas maiores alturas de pasto, devido a maior quantidade de drenos metabólicos nessas alturas (inflorescências). Esse fato poderia ser ratificado considerando-se que os pastos mais altos apresentaram os valores mais elevados de estoque de CNE, indicando um maior balanço de energia na planta, assim como uma maior disponibilidade de esqueletos carbônicos para a formação de compostos que seriam utilizados na formação de novos tecidos.

Com relação ao mês, o padrão de comportamento dos estoques de nitrato foi decrescente ao longo do período experimental, de modo que o menor estoque foi determinado para o mês de fevereiro. A redução mais marcante em estoque de nitrato foi detectada entre os meses de outubro e novembro, sendo que nesse último mês a planta provavelmente atingiu a maior taxa de acúmulo de forragem, o que implicaria em grande absorção, assimilação e fixação de nitrogênio em esqueletos carbônicos para a formação de novos tecidos. Conforme foi comentado anteriormente com relação aos teores de nitrato, o valor mais elevado de estoque desse ânion poderia estar associado a uma menor quantidade de CNE e, consequentemente, um menor balanço de energia na planta forrageira, de modo que o nitrogênio absorvido deve ter sido temporariamente armazenado na forma de nitrato (Engels \& Marschner, 1995) o que, neste caso, foi motivado pelo estádio reprodutivo de desenvolvimento. Em fevereiro, foi observada, novamente, uma redução no estoque de nitrato, o que poderia, mais uma vez, estar relacionado com o uso desse composto pela planta como consequência da maior exigência gerada pelas inflorescências.

No tocante à parte da planta, contrariamente ao que foi constatado para os teores de nitrato, não houve transição de importância entre os órgãos de reserva. Assim, nos meses em que foram observadas diferenças, a parte aérea apresentou consistentemente os maiores valores de estoque de nitrato. Esse fato corrobora a inferência feita 
anteriormente sobre a possibilidade de estar ocorrendo uma mobilização do nitrato do sistema radicular para a parte aérea e, em seguida, para folhas e/ou inflorescências.

\subsection{Nitrogênio em folhas $(\mathrm{N})$}

Os resultados referentes aos teores de $\mathrm{N}$ em folhas são apresentados na Tabela 24 e nas Figuras 45, 46 e 47. Houve efeito de mês $(\mathrm{P}<0,0001)$, de categoria de folha $(\mathrm{P}<0,0001)$ e da interação altura $\mathrm{x}$ mês $(\mathrm{P}=0,0066)$. Os teores de $\mathrm{N}$ durante o período experimental variaram entre 7,0 (40 cm, folha senescente, fevereiro) e $21,7 \mathrm{~g} \mathrm{~kg}^{-1}(10$ $\mathrm{cm}$, folha em expansão, dezembro). O maior teor médio dentre as categorias de folha foi observado para as folhas em expansão $\left(16,7 \mathrm{~g} \mathrm{~kg}^{-1}\right)$, ao passo que o menor teor médio foi obtido para as folhas senescentes $\left(11,4 \mathrm{~g} \mathrm{~kg}^{-1}\right)$ (Figura 45). Com relação ao mês, o maior teor médio de $\mathrm{N}$ foi determinado para dezembro $\left(17,4 \mathrm{~g} \mathrm{~kg}^{-1}\right)$, sendo que o menor teor foi observado em janeiro (11,6 $\mathrm{g} \mathrm{kg}^{-1}$ ) (Figura 46). A interação altura x mês permitiu inferir que existiu uma tendência de diminuição dos teores de $\mathrm{N}$ na medida em que a altura do pasto aumentou (Figura 47), exceção feita a altura de $30 \mathrm{~cm}$ no mês de janeiro, responsável pela ocorrência da interação altura x mês. O padrão de comportamento observado para os teores de $\mathrm{N}$ em relação às categorias de folhas estudadas foi crescente no sentido das folhas senescentes para aquelas em expansão, conforme seria esperado (Thomas \& Stoddart, 1980; Feller \& Fischer, 1994; Fernandes \& Rossiello, 1995; Hörtensteiner \& Feller, 2002). A redução dos teores em folhas é o resultado de um processo altamente organizado e muito bem regulado pela planta, conhecido como senescência (Thomas \& Stoddart, 1980; Feller \& Fischer, 1994; Hörtensteiner \& Feller, 2002). Resumidamente, devido à complexidade do assunto, durante esse processo, que caracteriza o estágio final de desenvolvimento da folha em que há a transição da assimilação de nutrientes para a remobilização desses elementos, ocorre uma intensa proteólise nos cloroplastos, de modo que os produtos da degradação das proteínas, na sua maioria aminoácidos, são exportados para as regiões de crescimento da planta (Feller \& Fischer, 1994; Hörtensteiner \& Feller, 2002). Esse processo determina, 
Tabela 24. Teores de nitrogênio $\left(\mathrm{g} \mathrm{kg}^{-1}\right)$ em folhas senescentes, maduras e em expansão de braquiária brizanta mantida em quatro alturas de pasto, de dezembro de 2001 a fevereiro de 2002.

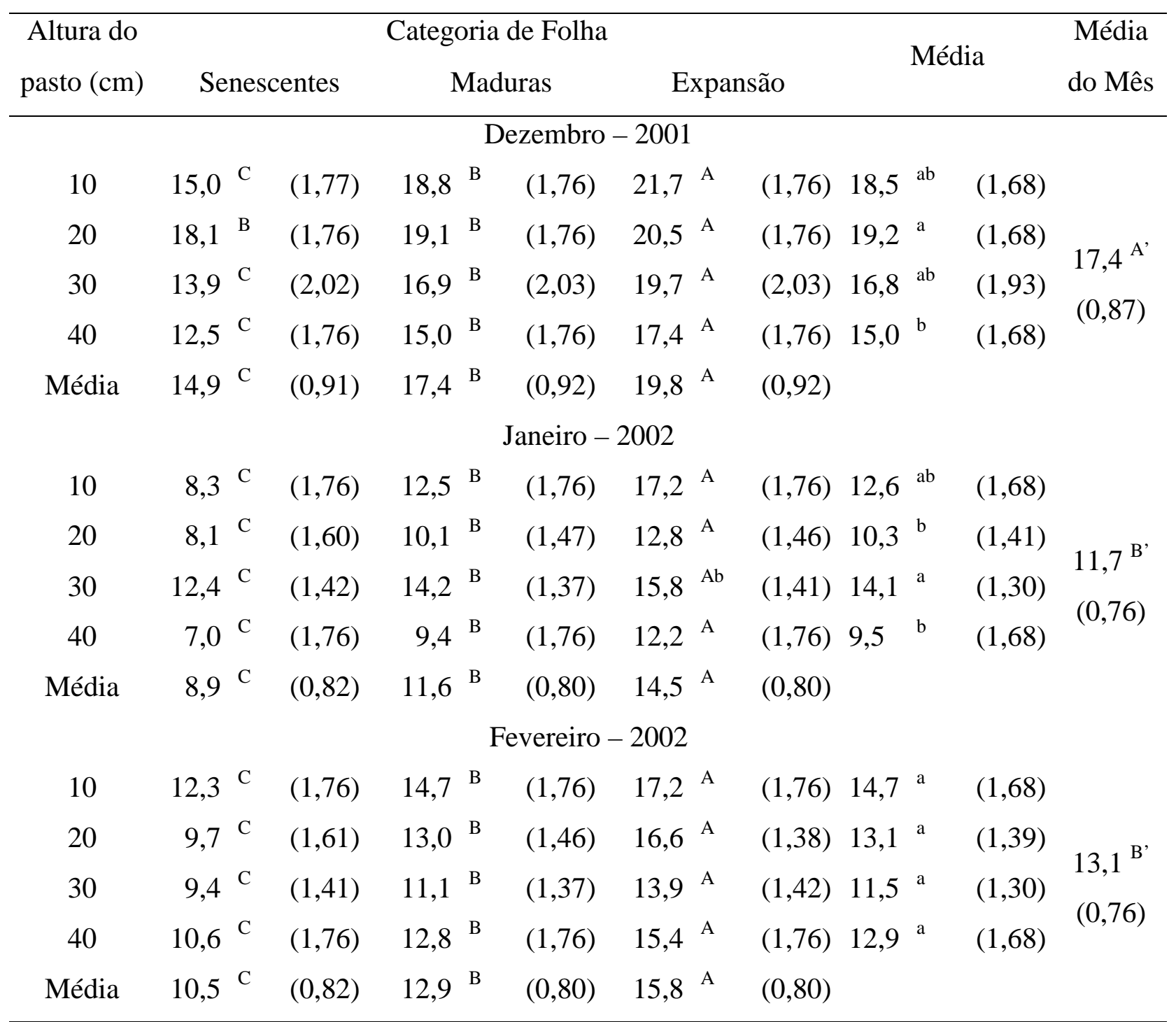

Valores entre parênteses indicam o Erro Padrão da Média (EPM).

Médias na linha seguidas de mesmas letras maiúsculas não diferem entre si $(\mathrm{P}>0,10)$.

Médias na coluna seguidas de mesmas letras minúsculas não diferem entre si ( $P>0,10)$. 


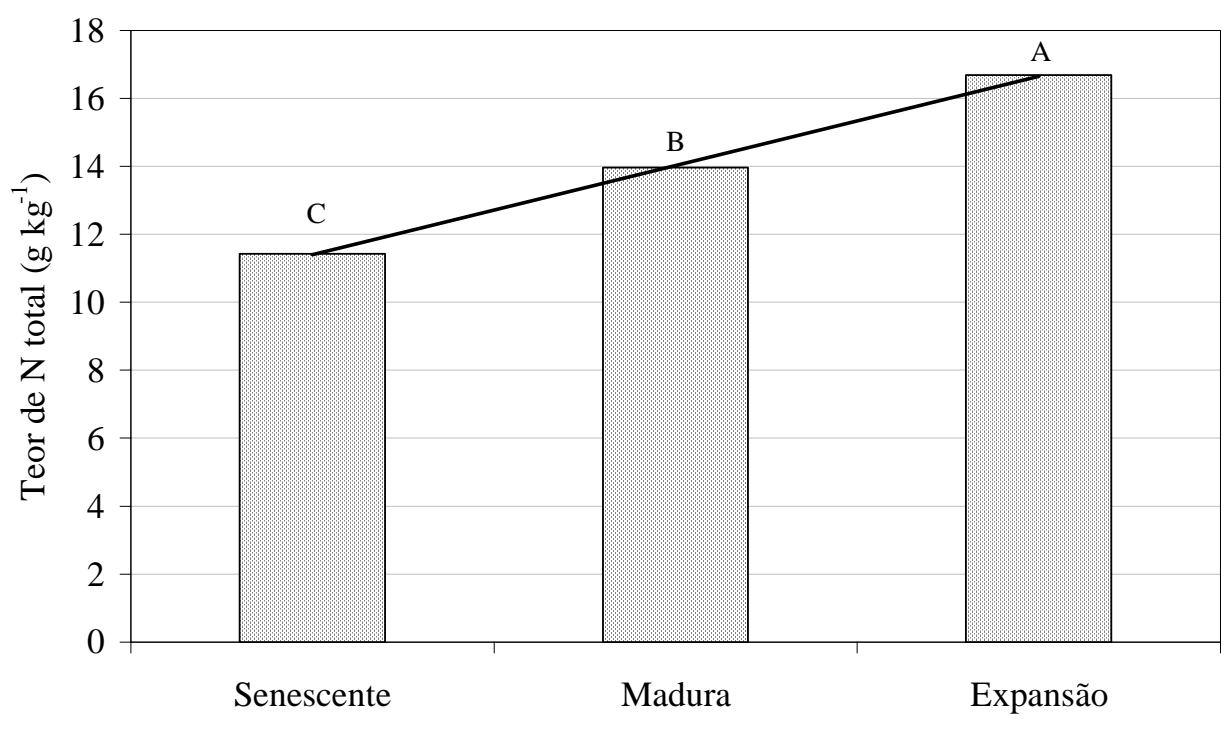

Categoria de Folha

Linha de tendência das médias

Figura 45 - Teores de nitrogênio em folhas senescentes, maduras e em expansão de braquiária brizanta mantida em diferentes alturas de pasto.

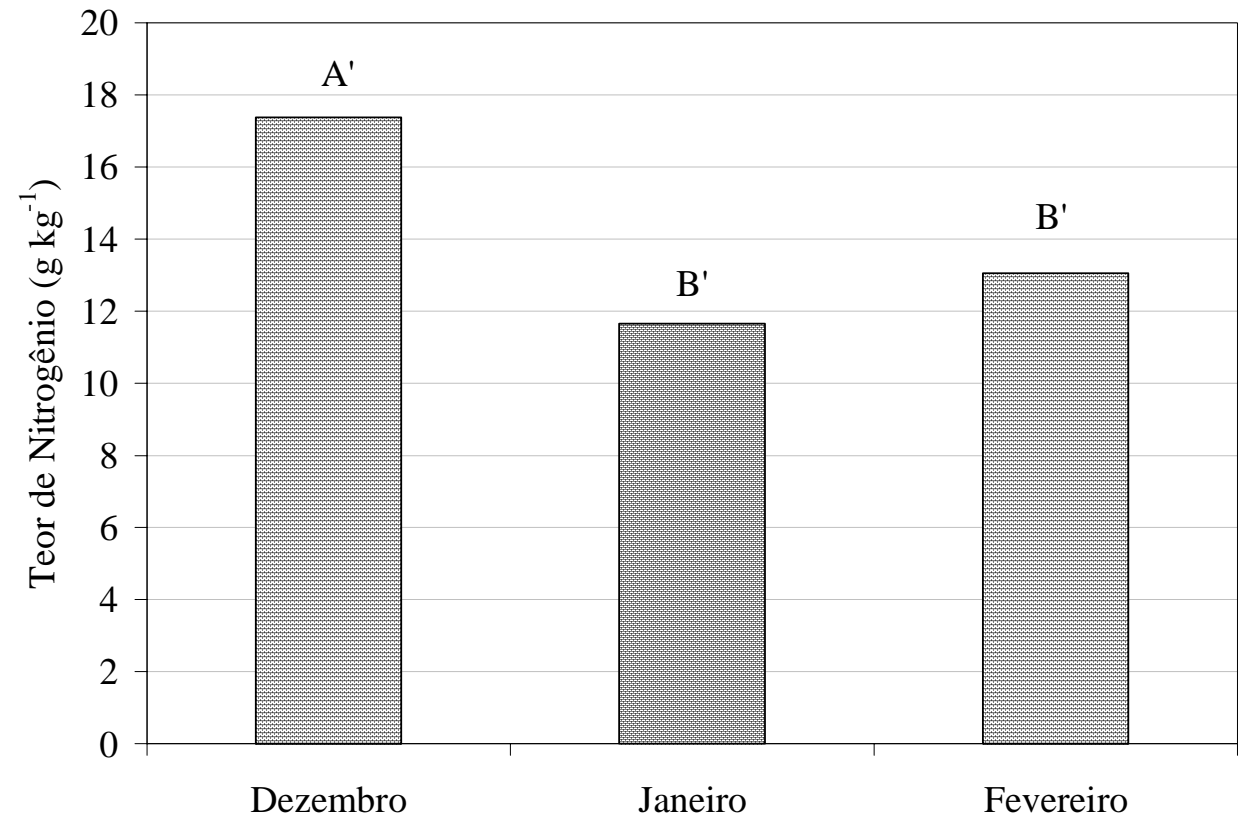

Figura 46 - Teores de nitrogênio em folhas de braquiária brizanta, de dezembro de 2001 a fevereiro de 2002 . 


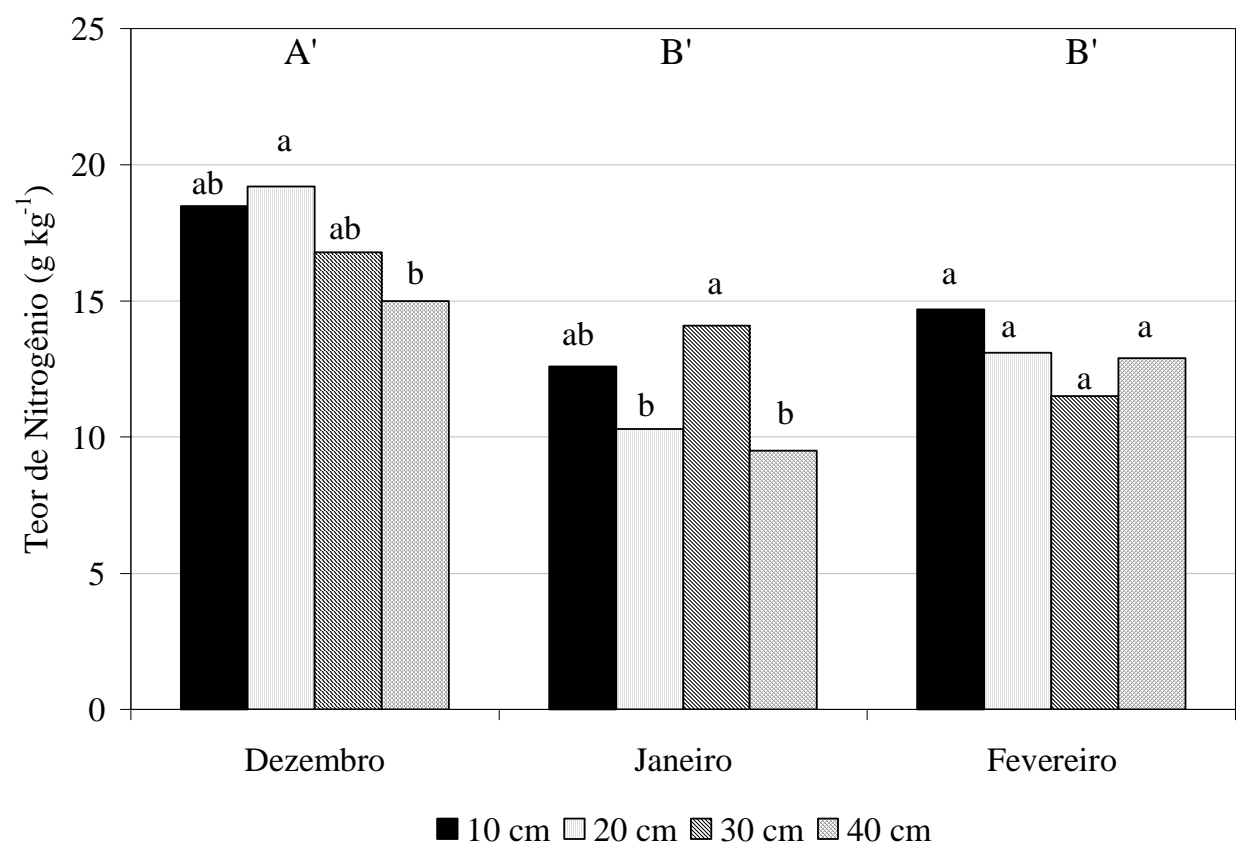

Figura 47 - Teores de nitrogênio de braquiária brizanta mantida em quatro alturas de pasto de dezembro de 2001 a fevereiro de 2002.

portanto, que os teores de nitrogênio em folhas senescentes sejam inferiores àqueles encontrados para folhas maduras que, por sua vez, devem apresentar teores menores do que folhas em expansão (Figura 45).

Com relação ao mês, o padrão de comportamento caracterizado pela redução dos teores de dezembro a fevereiro, poderia estar diretamente associado a uma mobilização desse elemento para o processo reprodutivo, onde uma vez mais poderia estar ocorrendo algum tipo de regulação/controle hormonal no sentido de direcionar o nitrogênio para os colmos reprodutivos, inflorescências e sementes. Conforme discutido anteriormente, durante o mês de janeiro ocorreu uma redução bastante acentuada nos estoques de CNE e nitrogênio solúvel, o que estaria sinalizando para a existência de um dreno bastante forte, no caso os colmos reprodutivos e as inflorescências da brizanta.

No tocante às diferenças de altura dentro de mês, o padrão decrescente verificado está de acordo com o que foi relatado por Lemaire \& Gastal (1997). Essa diferença seria esperada, visto que as folhas que se encontram nos pastos mais baixos devem ser mais 
jovens do que àquelas presentes nos pastos mais altos, em decorrência da maior frequência de desfolha associada à menor longevidade das folhas características dos pastos mais baixos ${ }^{5}$. Portanto, os órgãos compostos por tecidos mais jovens deveriam apresentar maiores concentrações de nitrogênio (Lemaire \& Gastal, 1997; Hörtensteiner \& Feller, 2002).

\subsection{Taxa de acúmulo e produção de forragem}

Os resultados referentes às taxas de acúmulo de forragem são apresentados na Tabela 25 e nas Figuras 48, 49 e 50. Houve efeito de altura ( $\mathrm{P}=0,0996)$, mês ( $\mathrm{P}<0,0001)$ e da interação altura x mês $(\mathrm{P}=0,0215)$. Os valores médios de taxa de acúmulo variaram entre 78,4 (40 cm, fevereiro) e 144,8 $\mathrm{kg} \mathrm{ha}^{-1} \mathrm{dia}^{-1}$ de massa seca (30 cm, novembro). A maior taxa média de acúmulo de forragem foi encontrada para a altura de $30 \mathrm{~cm}(121,6$ $\left.\mathrm{kg} \mathrm{ha}^{-1} \mathrm{dia}^{-1}\right)$, a qual não diferiu das taxas de acúmulo determinadas para as alturas de 20 $\left(118,5 \mathrm{~kg} \mathrm{ha}^{-1} \mathrm{dia}^{-1}\right)$ e $40 \mathrm{~cm}\left(113,9 \mathrm{~kg} \mathrm{ha}^{-1} \mathrm{dia}^{-1}\right)$. A taxa de acúmulo correspondente à altura de $30 \mathrm{~cm}$ foi, portanto, diferente daquela relativa à altura de pasto de $10 \mathrm{~cm}(103,6$ $\mathrm{kg} \mathrm{ha}^{-1} \mathrm{dia}^{-1}$ ), sendo que o mesmo foi observado para a altura de $20 \mathrm{~cm}$. As taxas de acúmulo obtidas nas alturas de 10 e $40 \mathrm{~cm}$ foram semelhantes. Com relação ao mês, a maior taxa de acúmulo de forragem foi observada em novembro $\left(126,9 \mathrm{~kg} \mathrm{ha}^{-1} \mathrm{dia}^{-1}\right)$, ao passo que o menor valor foi determinado para fevereiro $\left(97,2 \mathrm{~kg} \mathrm{ha}^{-1} \mathrm{dia}^{-1}\right)$. Os valores correspondentes aos meses de novembro, dezembro $\left(116,1 \mathrm{~kg} \mathrm{ha}^{-1} \mathrm{dia}^{-1}\right)$ e janeiro $(116,0$ $\mathrm{kg} \mathrm{ha}^{-1} \mathrm{dia}^{-1}$ ) foram semelhantes entre si, porém distintos daquele obtido para fevereiro.

O padrão de comportamento das taxas médias de acúmulo de forragem em relação às alturas de pasto estudadas foi inicialmente crescente, atingindo um platô entre as alturas de 20 e $40 \mathrm{~cm}$ (Figura 48). Esse padrão de comportamento alerta para o fato de que estratégias de manejo do pastejo caracterizadas por desfolha intensa e frequente,

\footnotetext{
${ }^{5}$ GONÇALVES, A.C. (Escola Superior de Agricultura "Luiz de Queiroz", Piracicaba, SP). Intensidade e frequência de desfolha em pastos de Brachiaria brizantha cv. Marandu. (Dissertação de mestrado em elaboração)
} 
Tabela 25. Taxas de acúmulo de forragem $\left(\mathrm{kg} \mathrm{ha}^{-1} \mathrm{dia}^{-1}\right)$ de braquiária brizanta mantida em quatro alturas de pasto, de novembro de 2001 a fevereiro de 2002.

\begin{tabular}{|c|c|c|c|c|c|c|c|c|c|c|}
\hline \multirow{2}{*}{ Mês } & \multicolumn{8}{|c|}{ Altura do Pasto $(\mathrm{cm})$} & \multirow{2}{*}{ Média } & \multirow{2}{*}{$\mathrm{EPM}^{*}$} \\
\hline & 10 & & 20 & & 30 & & 40 & & & \\
\hline Novembro & 125,6 & $\mathrm{Aa}$ & 108,5 & $\mathrm{BCa}$ & 144,8 & $\mathrm{Aa}$ & 128,5 & $\mathrm{Aa}$ & $126,9^{\mathrm{A}}$ & 5,93 \\
\hline Dezembro & 104,2 & $\mathrm{ABa}$ & 127,9 & $\mathrm{ABa}$ & 107,1 & $\mathrm{Ba}$ & 125,3 & Aa & $116,1^{\mathrm{A}}$ & 5,94 \\
\hline Janeiro & 85,4 & $\mathrm{Bc}$ & 135,7 & Aa & 119,1 & $\mathrm{Bb}$ & 123,6 & Aab & $116,0^{\mathrm{A}}$ & 3,02 \\
\hline Fevereiro & 92,7 & $\mathrm{Bb}$ & 102,0 & $\mathrm{Cab}$ & 115,4 & $\mathrm{Ba}$ & 78,4 & $\mathrm{Bb}$ & $97,2^{\text {В }}$ & 5,26 \\
\hline Média & 102,0 & b & 118,5 & a & 121,6 & & 113,9 & & & \\
\hline $\mathrm{EPM}^{*}$ & 5,05 & & 5,19 & & 5,19 & & 7,16 & & & \\
\hline
\end{tabular}

*EPM - Erro padrão da média.

Médias na linha seguidas de mesmas letras minúsculas não diferem entre si $(\mathrm{P}>0,10)$.

Médias na coluna seguidas de mesmas letras maiúsculas não diferem entre si $(P>0,10)$.

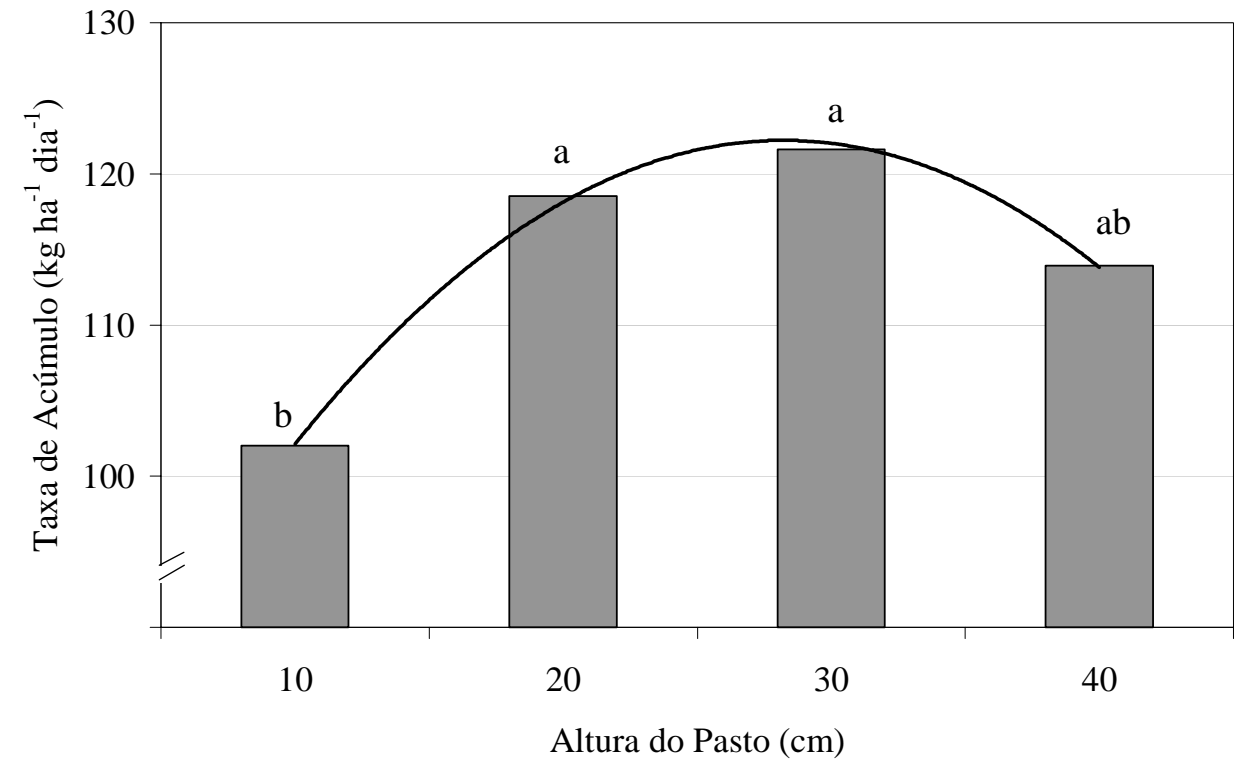

— Linha de tendência das médias

Figura 48 - Taxa de acúmulo de massa seca de braquiária brizanta mantida em diferentes alturas de pasto. 


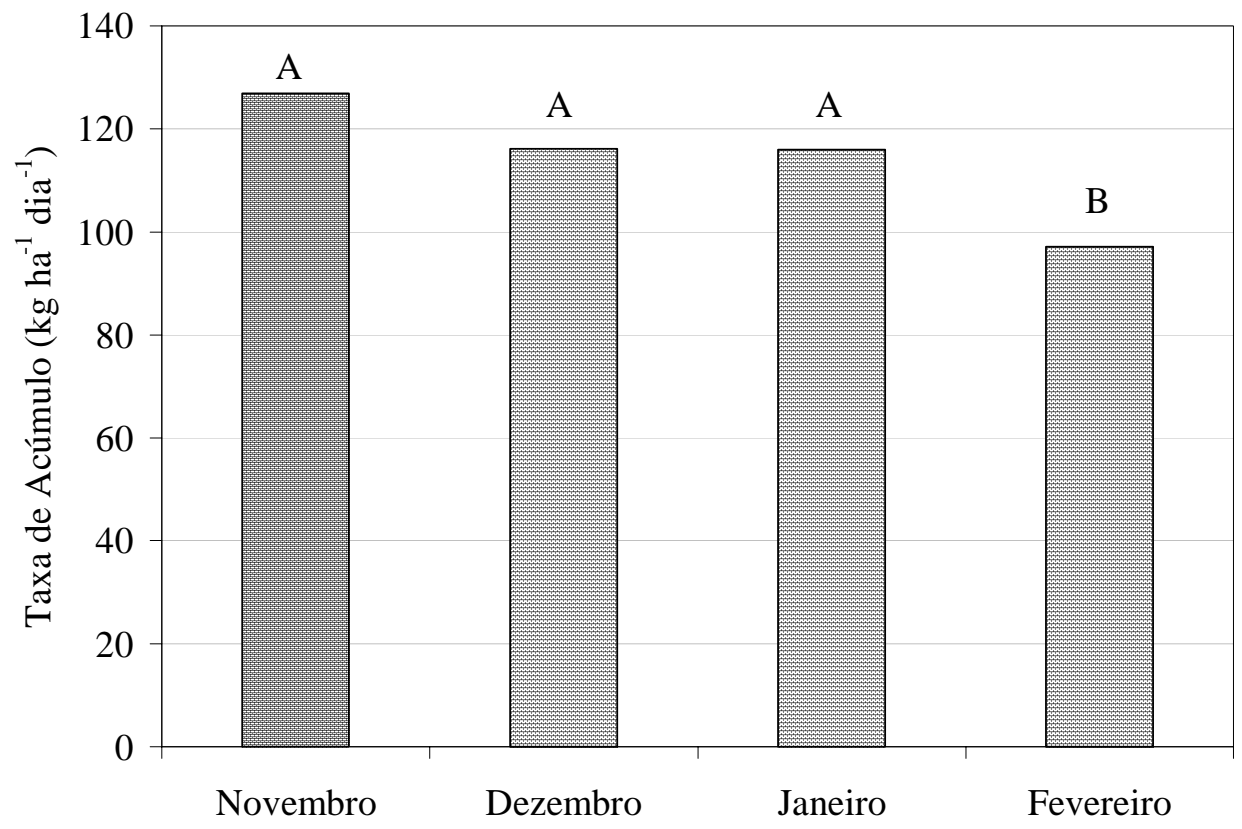

Figura 49 - Taxa de acúmulo de forragem em pastos de braquiária brizanta, de novembro de 2001 a fevereiro de 2002.

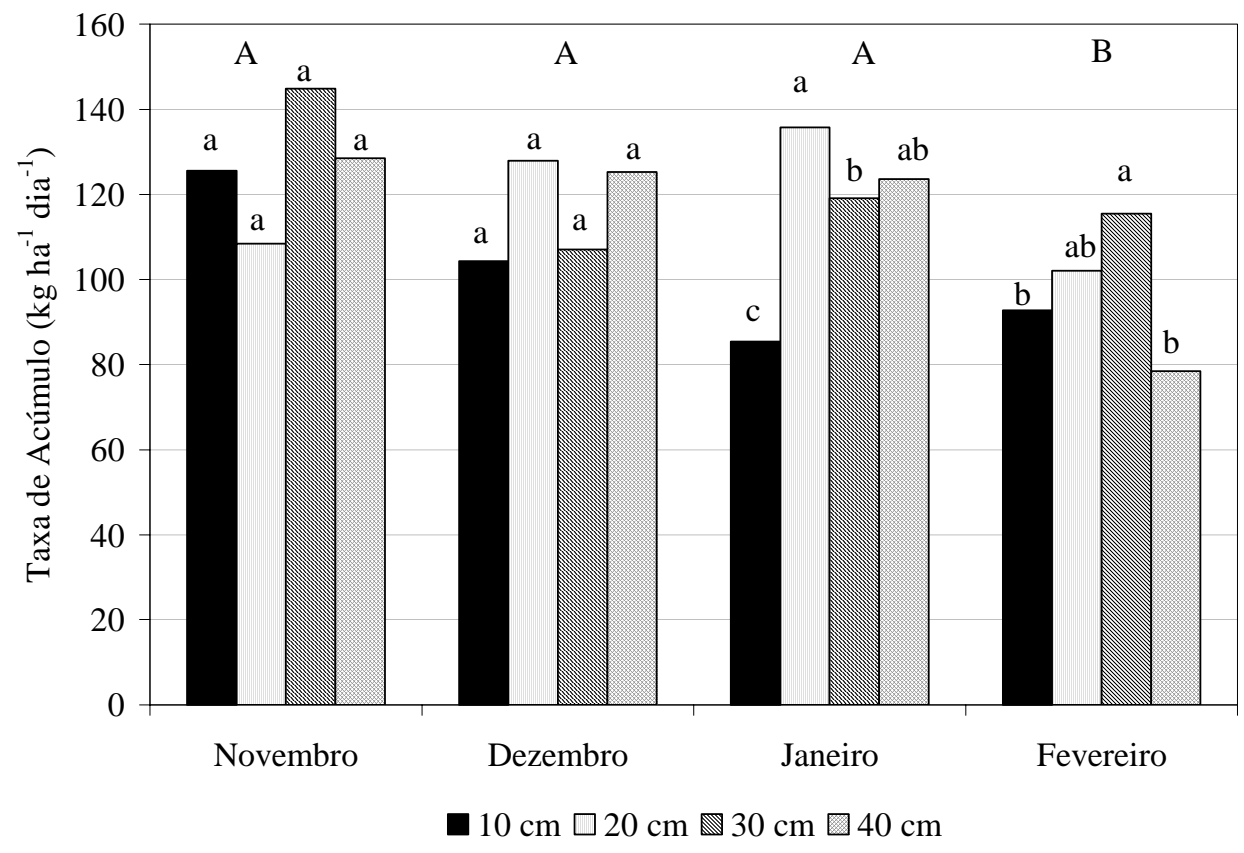

Figura 50 - Taxa de acúmulo de forragem de braquiária brizanta mantida em quatro alturas de pasto, de novembro de 2001 a fevereiro de 2002. 
neste experimento exemplificadas pela condição de pasto de $10 \mathrm{~cm}$, não resultam em benefício algum em termos de taxa de acúmulo de forragem, consequência de baixos valores de IAF e interceptação luminosa dos pastos ${ }^{1}$. Da mesma forma, regimes de desfolha caracterizados por baixa frequência e baixa intensidade de pastejo também podem gerar prejuízos para a produção de forragem, particularmente como consequência de processo muito intenso de senescência, morte e decomposição de tecidos (Hodgson, 1990), condição essa próxima daquela representa pela altura de pasto de $40 \mathrm{~cm}$ no presente experimento ${ }^{2}$. Por outro lado, os resultados apontam para uma faixa de utilização do pasto $(20-40 \mathrm{~cm})$ dentro da qual a taxa de acúmulo é muito próxima, embora as características estruturais do pasto sejam distintas ${ }^{1,2}$ e, assim, demonstram a amplitude da plasticidade fenotípica e de flexibilidade de uso dessa planta forrageira.

Com relação ao mês, não houve diferenças entre novembro, dezembro e janeiro, dentro dos quais foram observadas as maiores taxas de acúmulo de forragem. Em fevereiro, considerando-se a intensificação do processo de florescimento ${ }^{2}$, associada à redução em radiação solar e temperatura média (Tabela 2), foram observadas as menores taxas de acúmulo, de modo que a redução mais acentuada foi detectada na altura de pasto de $40 \mathrm{~cm}$. Os resultados de taxa de acúmulo para cultivares de Cynodon spp., apresentados por Pinto (2000), corroboram o dados obtidos neste experimento no que diz respeito à redução marcante na taxa de acúmulo durante o estádio reprodutivo. Nessa fase de desenvolvimento, as inflorescências e a produção de sementes são drenos muito fortes, de modo que grande parte do que é absorvido (nutrientes) ou acumulado (reservas orgânicas) e produzido (fotoassimilados) são quase que exclusivamente direcionados para a perpetuação da espécie (Snyder \& Carlson, 1984) gerando, como consequência, queda nas taxas de acúmulo de forragem (Pinto, 2000).

\footnotetext{
${ }^{1}$ MOLAN, L.K. (Escola Superior de Agricultura "Luiz de Queiroz", Piracicaba, SP). Estrutura do dossel e interceptação luminosa em pastos de Brachiaria brizantha cv. Marandu. (projeto de mestrado em andamento)

${ }^{2}$ SBRISSIA, A.F. (Escola Superior de Agricultura "Luiz de Queiroz", Piracicaba, SP). Perfilhamento, compensação tamanho/densidade populacional de perfilhos e fluxo de tecidos em pastos de Brachiaria brizantha cv. Marandu. (projeto de doutorado em andamento)
} 
No tocante ao comportamento das alturas de pasto nos meses estudados, pode-se notar, de uma forma geral, que houve uma tendência de aumento da taxa de acúmulo da altura de pasto de $10 \mathrm{~cm}$ para as demais alturas. Esse fato somente não foi ratificado em fevereiro, possivelmente em função do intenso florescimento nos pastos mais altos nessa época do ano.

Os resultados relativos à produção acúmulo de forragem da braquiária brizanta nas alturas de pasto estudadas durante o período experimental são apresentados na Tabela 26 e na Figura 51. Houve efeito de altura $(\mathrm{P}=0,0522)$, muito embora deva ser considerada a limitação do método utilizado para esse fim, conforme foi descrito por Parsons et al. (1988 c) e Pinto (2000). Nesse sentido, as gaiolas de exclusão poderiam estar favorecendo o acúmulo de forragem nas menores alturas de pasto e, concomitantemente, subestimando-o nos pastos mais altos, diminuindo a amplitude de eventuais diferenças entre pastos baixos e altos. Uma forma de ajustar esses desvios seria a utilização dos dados provenientes das avaliações de fluxo de tecidos (morfogênese) $)^{2}$.

Considerando a limitação da técnica, os resultados apontaram para uma vantagem nas alturas de pasto de 20 a $40 \mathrm{~cm}$, dentro das quais poderia ser suposto que ocorreu um melhor balanço entre os processos determinantes da produção de forragem (crescimento e senescência), conforme discutido com propriedade por Parsons et al. (1988 c).

\footnotetext{
${ }^{2}$ SBRISSIA, A.F. (Escola Superior de Agricultura "Luiz de Queiroz", Piracicaba, SP). Perfilhamento, compensação tamanho/densidade populacional de perfilhos e fluxo de tecidos em pastos de Brachiaria brizantha cv. Marandu. (projeto de doutorado em andamento)
} 
Tabela 26. Produção de forragem de braquiária brizanta $\left(\mathrm{kg} \mathrm{ha}^{-1}\right.$ de massa seca), de novembro de 2001 a fevereiro de 2002.

\begin{tabular}{cc}
\hline Altura do Pasto $(\mathrm{cm})$ & Produtividade $\left(\mathrm{kg} \mathrm{ha}^{-1}\right)$ \\
\hline 10 & $10.300^{\mathrm{B}}$ \\
20 & $13.340^{\mathrm{A}}$ \\
30 & $12.620^{\mathrm{A}}$ \\
40 & $13.880^{\mathrm{A}}$ \\
Média & 13.220 \\
EPM* $^{*}$ & 810
\end{tabular}

*EPM: Erro Padrão da Média.

Médias na coluna seguidas de mesmas letras maiúsculas não diferem entre si $(\mathrm{P}>0,10)$.

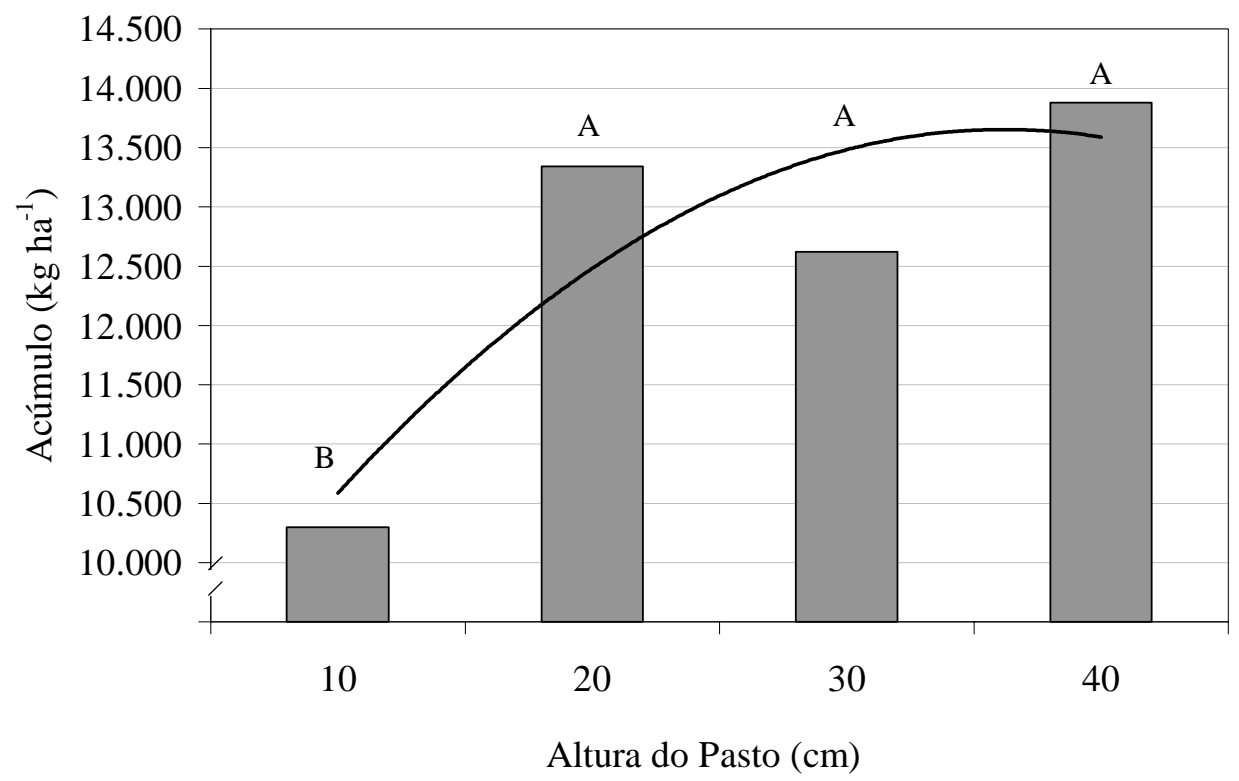

— Linha de tendência das médias

Figura 51 - Produção de forragem de braquiária brizanta mantida em quatro alturas, de pasto de novembro de 2001 a fevereiro de 2002. 


\subsection{Considerações finais}

A apreciação geral dos resultados obtidos ao longo do período experimental revelou que as condições de pasto estudadas representadas pelas alturas de 10, 20, 30 e $40 \mathrm{~cm}$, foram suficientes para gerar os contrastes desejados e possibilitaram a visualização de padrões bastante consistentes de respostas.

Os resultados apontaram para um aumento nos valores de IAF, taxa de acúmulo e acúmulo de forragem com o aumento da altura de pasto de 10 para $40 \mathrm{~cm}$ (Figura 52). No entanto, foi detectado um platô a partir da altura de $20 \mathrm{~cm}$, indicando que, em termos de produção de forragem, não existiu vantagem alguma na manutenção do pasto nas alturas de 30 e $40 \mathrm{~cm}$. A altura de pasto de $10 \mathrm{~cm}$ correspondeu a uma condição de desfolha drástica o suficiente para a braquiária brizanta e, portanto, não seria recomendada para uso em sistemas pastoris.

No tocante às massas dos órgãos de reserva, ficou aparente que a brizanta preferiu, consistentemente, lançar mão de reduções nas massas da parte aérea (base do colmo), de tal sorte que mesmo durante a fase reprodutiva a redução na massa do sistema radicular foi muito menos intensa comparativamente à parte aérea.

Com relação aos teores e estoques de compostos de reserva, dentro da amplitude de condições de pasto estudada, foi possível distinguir dois padrões de comportamento, um para carboidratos não estruturais e outro para frações nitrogenadas (Figuras 53 e 54). Ocorreu um incremento nos teores e estoques de carboidratos à medida em que a altura de pasto aumentou, revelando que os pastos mais altos foram capazes de acumular uma maior quantidade de energia e indicando, mais uma vez, a drasticidade do regime de desfolha imposta pela condição de pasto de $10 \mathrm{~cm}$. Já para as frações nitrogenadas, o padrão de comportamento detectado foi inverso, de modo que os estoques e teores dos compostos nitrogenados decresceram com o aumento da altura de pasto, apontando para o fato de que as plantas mantidas em pastos mais altos não devem investir no acúmulo de reservas nitrogenadas, ou mesmo, acumulam o mínimo necessário.

Foi observada uma redução marcante nos teores e estoques tanto de carboidratos não estruturais como das frações nitrogenadas ao longo do período experimental, 
principalmente devido à passagem do estádio de desenvolvimento vegetativo para o reprodutivo. Esse fato também mostrou a força dos órgãos reprodutivos como drenos metabólicos (Figura 55 e 56) e o impacto potencial que sua ocorrência pode ter sobre a produção de forragem e a estratégia de pastejo a ser adotada em diferentes épocas do ano. A redução nos teores e estoques de reservas orgânicas apontam para o risco potencial de práticas de manejo no final do verão, especificamente aquelas relacionadas com desfolhas drásticas e freqüentes, dada a possibilidade de perda e/ou redução da capacidade de perfilhamento e restauração de IAF nessas circunstâncias, podendo resultar em problemas de diminuição da população de plantas e degradação dos pastos.

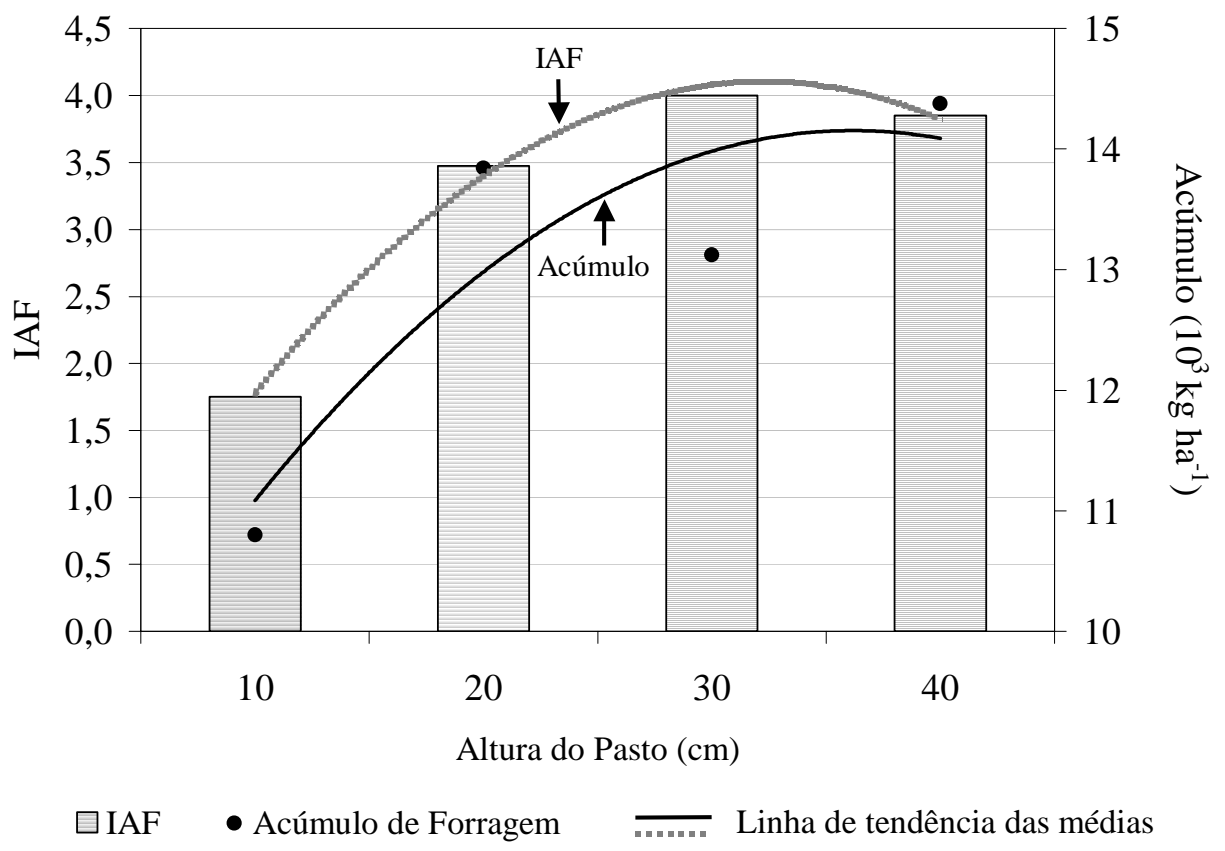

Figura 52 - Índice de área foliar e acúmulo de forragem de pastos de braquiária brizanta mantida em diferentes alturas de pasto. 


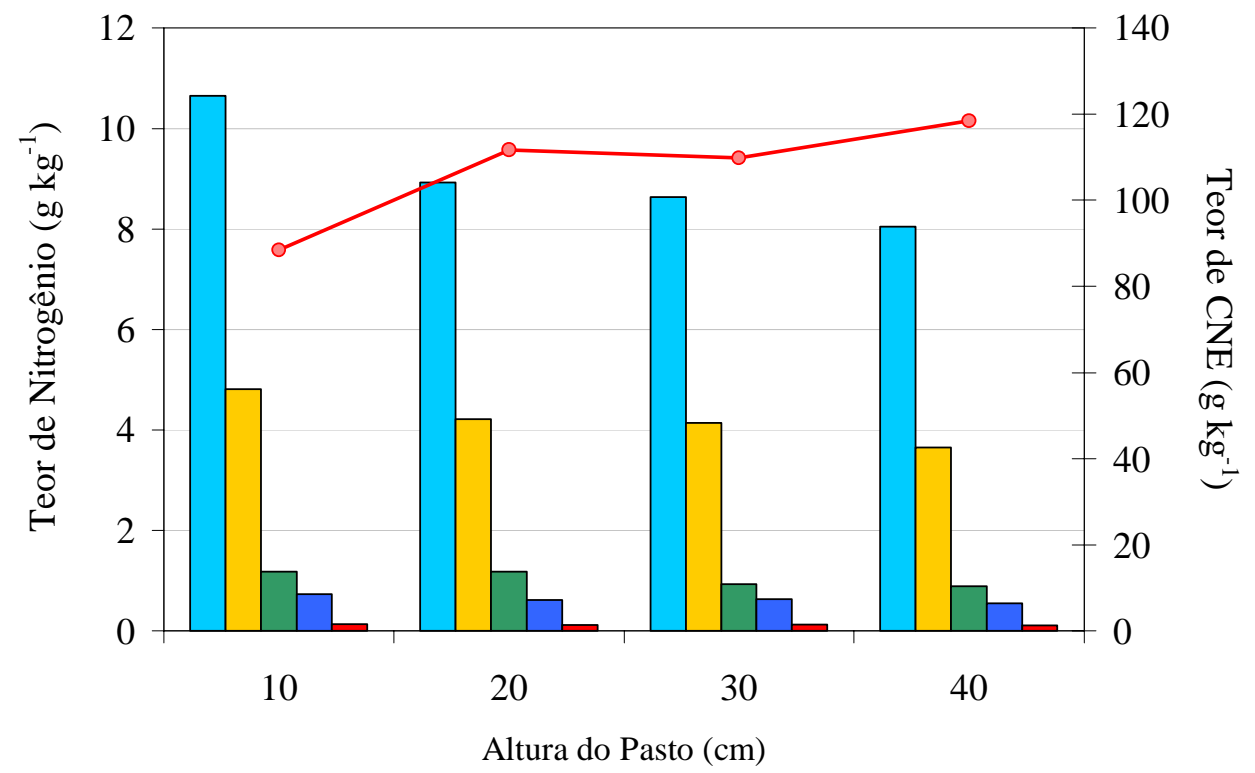

$\square$ Total $\square$ Solúvel $\square$ Aminoácidos $\square$ Amônio $\square$ Nitrato —- CNE

Figura 53 - Teores de CNE e frações nitrogenadas de braquiária brizanta mantida em diferentes alturas de pasto.

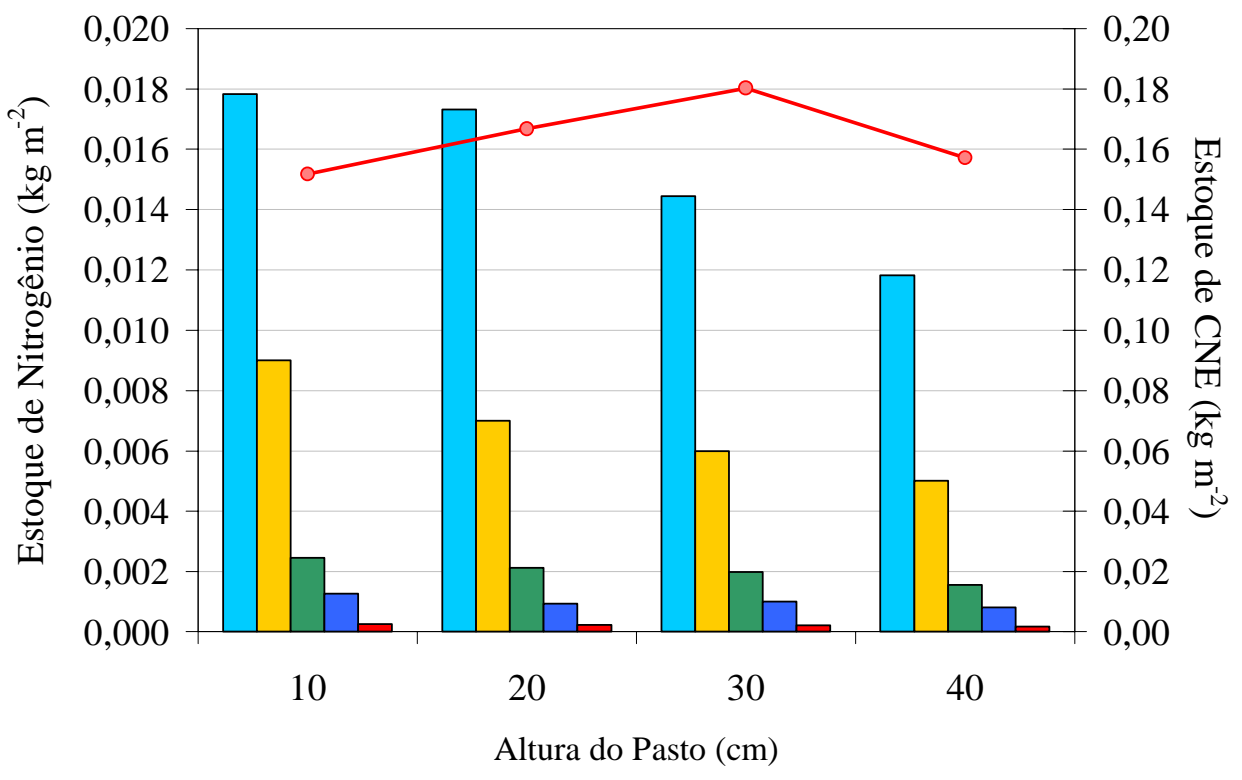

$\square$ Total $\square$ Solúvel $\square$ Aminoácidos $\square$ Amônio $\square$ Nitrato $\multimap$ CNE

Figura 54 - Estoques de CNE e frações nitrogenadas de braquiária brizanta mantida em diferentes alturas de pasto. 


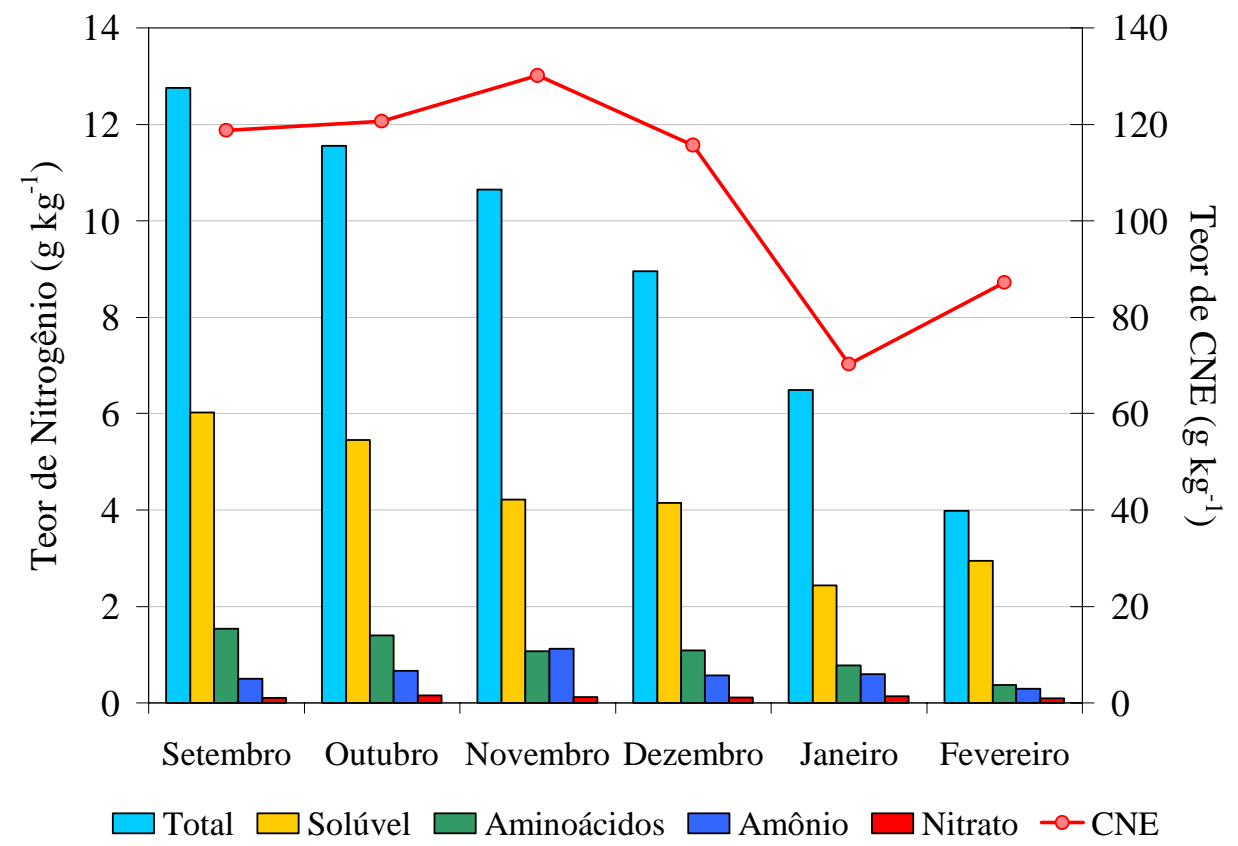

Figura 55 - Teores de CNE e frações nitrogenadas em pastos de braquiária brizanta, de setembro de 2001 a fevereiro de 2002.

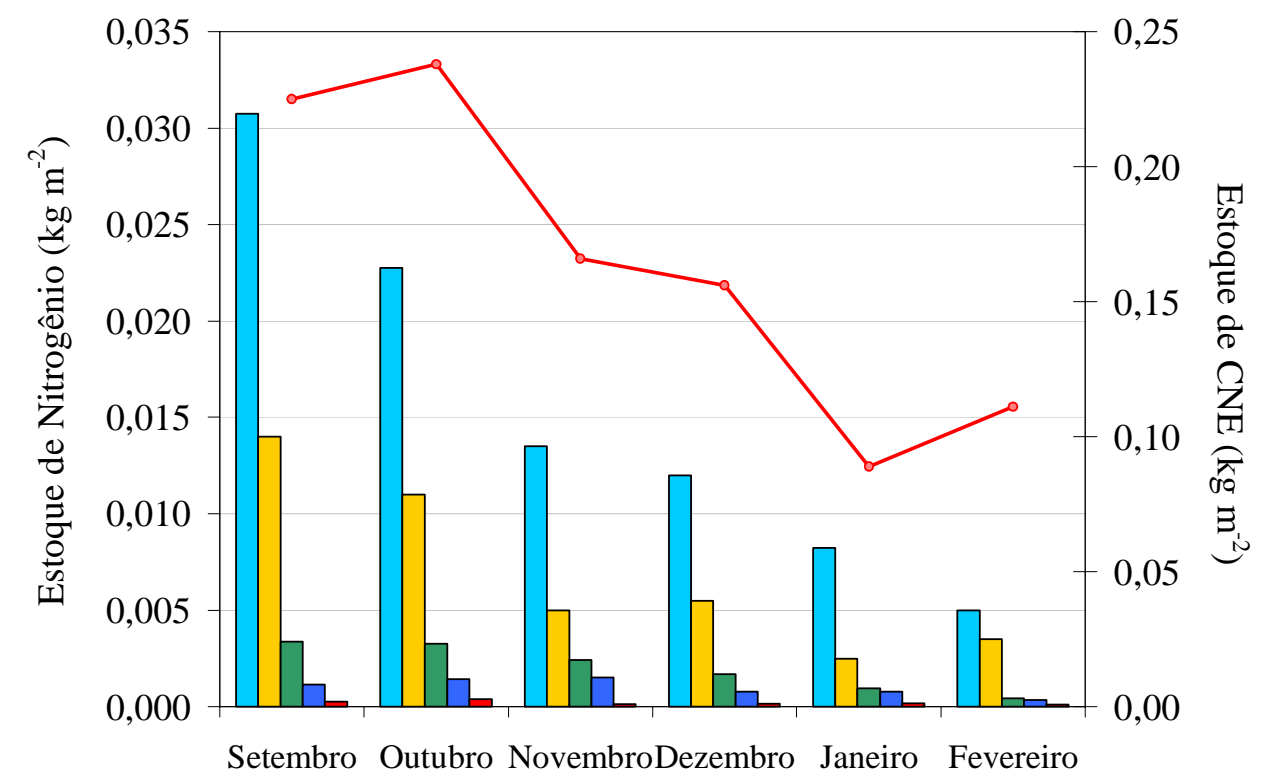

$\square$ Total $\square$ Solúvel $\square$ Aminoácidos $\square$ Amônio $\square$ Nitrato $\multimap$ CNE

Figura 56 - Estoques de CNE e frações nitrogenadas em pastos de braquiária brizanta, de setembro de 2001 a fevereiro de 2002. 


\section{CONCLUSÕES}

- A amplitude de condições de pasto utilizada foi suficiente para detectar os padrões de variação das variáveis-resposta estudadas.

- O conjunto de dados gerados com relação às reservas de carboidratos não estruturais e de compostos nitrogenados foi bastante consistente, apesar da curta duração do experimento, e revelou um padrão oposto de comportamento em função da condição de pasto estudada, porém uniforme com relação ao estádio de desenvolvimento dos pastos.

- As reservas estocadas na base dos colmos foram utilizadas preferencialmente àquelas estocadas nas raízes.

- As inflorescências se mostraram um dreno metabólico muito forte e interferiram nos padrões de variação dos teores e estoques de compostos de reserva das plantas.

- O teor de nitrogênio das folhas sofreu interferência do estádio de desenvolvimento das plantas, sendo mais baixo durante a fase reprodutiva.

- Ocorreu um platô para os valores de taxa de acúmulo e de produção de forragem entre as alturas de pasto de 20 e $40 \mathrm{~cm}$.

- A amplitude de condições de pasto representada pelas alturas de 20, 30 e $40 \mathrm{~cm}$ poderia ser utilizada no manejo do pastejo de Brachiaria brizantha cv. Marandu, sendo a escolha específica de um valor, função do objetivo e da natureza do sistema de produção idealizado. 


\section{REFERÊNCIAS BIBLIOGRÁFICAS}

ALCÂNTARA, P.B. Origem das braquiárias e suas características morfológicas de interesse forrageiro. In: ENCONTRO SOBRE CAPINS DO GÊNERO Brachiaria, Nova Odessa, 1986. Anais. Nova Odessa: IZ, 1987. p. 1-18.

ALEXANDRINO, E. Crescimento e características químicas e morfogênicas da Brachiaria brizantha cv. Marandu submetida a cortes e diferentes doses de nitrogênio. Viçosa, 2000. 132p. Dissertação (Mestrado) - Universidade Federal de Viçosa.

ARRUDA, Z.J. A pecuária bovina de corte no Brasil e resultados econômicos de sistemas alternativos de produção. In: SIMPÓSIO SOBRE PECUÁRIA DE CORTE, 4., Piracicaba, 1997. Anais. Piracicaba: FEALQ, 1997. p.259-273.

ASSOACIATION OFFICIAL ANALYTICAL CHEMISTS. Micro Kjeldahl method. In: CUNNIFF, P. (Ed.) Official methods of analysis of AOAC international. Arlington: AOAC, 1995 a. cap.12, p.7.

ASSOCIATION OFFICIAL ANALYTICAL CHEMISTS. Macro Kjeldahl method. In: CUNNIFF, P. (Ed.) Official methods of analysis of AOAC international. Arlington: AOAC, 1995 b. cap.2, p.13-14.

AVICE, J.C.; OURRY, A.; LEMAIRE, G.; BOUCAUD, J. Nitrogen ad carbon flows estimated by ${ }^{15} \mathrm{~N}$ and ${ }^{13} \mathrm{C}$ pulse-chase labeling during regrowth of alfalfa. Plant Physiology, v. 112, n.1, p.281-290, 1996a. 
AVICE, J.C.; OURRY, A.; VOLENEC, J.J.; LEMAIRE, G.; BOUCAUD, J. Defoliation-induced changes in abundance and immuno-localization of vegetative storage proteins in taproots of Medicago sativa. Plant Physiology Biochemistry, v. 34, n. 4, p.561-570, 1996 b.

AVICE, J.C.; OURRY, A.; LEMAIRE, G.; VOLENEC, J.J.; BOUCAUD, J. Root protein and vegetative storage protein are key organic nutrients for alfalfa shoot regrowth. Crop Science, v. 37, p.1187-1193, 1997a.

AVICE, J.C.; LEMAIRE, G.; OURRY, A.; BOUCAUD, J. Effects of the previous shoot removal frequency on subsequent shoot regrowth in two Medicago sativa cultivars. Plant and Soil, n. 188, p.189-198, 1997b.

BARCELlOS, A.O.; VILELA, L.; LUPINACCI, A.V. Produção animal a pasto: desafios e oportunidades. In: ENCONTRO NACIONAL DO BOI VERDE: A PECUÁRIA SUSTENTÁVEL, 3., Uberlândia, 2001. Anais. Uberlândia: Sindicato Rural de Uberlândia, 2001. p. 29-64.

BENICASA, M.M.P. Análise de crescimento de plantas. Jaboticabal: FUNEP, 1988. $42 \mathrm{p}$.

BERNATOWICZ, A.J. Teleology in science teaching. Science, n. 128, 1403-1405, 1958.

BIRCHAM, J.S.; HODGSON, J. The influence of swards conditions on rates of herbage growth and senescence in mixed swards under continuous grazing management. Grass and Forage Science, v. 38, p. 323-331, 1983.

BLASER, R. E.; HAMMES Jr. R.C.; FONTENOT, J. P.; BRYANT, H.T.; POLAN, C.E.; WOLF, D.D.; McClAUGHERTHY, F.S.; KLINE, R.G.; MOORE, J.S. Forage animal management systems. Blacksburg: Virginia Agricultural Experimental Station, 1986. 90 p. (Bulletin, 86-7).

BRASIL. Ministério da Agricultura. Serviço Nacional de Pesquisa Agronômica. Comissão de Solos. Levantamento de reconhecimento dos solos do Estado de São Paulo. Rio de Janeiro, 1960. 634p. (Boletim, 12). 
BRISKE, D.D. Strategies of plant survival in grazed systems: a functional interpretation. In: HODGSON, J.; ILLIUS, W. (Ed.) The ecology and management of grazing systems. London: CAB International, 1996. cap.2, p.37-67.

BROUGHAM, R.W. Effect of intensity of defoliation on regrowth of pasture. Australian Journal of Agricultural Research, v.7, n.2, p.377-387, 1956.

BROWN, R.H. Growth of the green plant. In: TESAR, M.B. Physiological basis of crop growth and development. Madison: ASA, CSSA, 1984. p. 153-174.

BROWN, R. H.; BLASER, R.E. Leaf area index in pasture growth. Herbage Abstracts, v. 38, p. 1-9, 1968.

CARVALHO, C.A.B.; DA SILVA, S.C.; SBRISSIA, A.F.; FAGUNDES, J.L.; CARNEVALLI, R.A.; PINTO, L.F.M.; PEDREIRA, C.G.S. Carboidratos não estruturais e acúmulo de forragem em pastagens de Cynodon spp. sob lotação contínua. Scientia Agricola, v.58, n.4, p.667-674, 2001.

CORE, N.; BOUCHART, V.; OURRY, A.; BOUCAUD, J. Mobilization of nitrogen reserves during regrowth of defoliated Trifolium repens $\mathrm{L}$. and identification of potential vegetative storage proteins. Journal of Experimental Botany, v.47, n.301, p. 1111-1118, 1996.

CORSI, M. Pastagens de alta produtividade. In: CONGRESSO BRASILEIRO DE PASTAGENS, 8., Piracicaba, 1986. Anais. Piracicaba: FEALQ, 1986. p. 499-511.

CORSI, M., BALSALOBRE, M. A.; SANTOS, P. M., SILVA, S. C. da. Bases para o estabelecimento do manejo de pastagens de braquiária.In: SIMPÓSIO SOBRE MANEJO DE PASTAGENS, 11., Piracicaba, 1994. Anais. Piracicaba: FEALQ, 1994. p. 249-266.

CUNNINGHAM, S.; VOLENEC, J.J. Purification and characterization of vegetative storage proteins from alfalfa (Medicago sativa L.) taproots. Journal of Plant Physiology, v.147, p.625-632, 1996.

CYR, D.R.; BEWLEY, J.D. Proteins in the roots of the perennial weeds chicory (Cichorium intybus L.) and dandelion (Taraxacum officinale Weber) are associated with overwintering. Planta, v.182, p.370-374, 1990. 
DA SILVA, S.C. Condições edafoclimáticas para a produção de Panicum sp. In: SIMPÓSIO SOBRE MANEJO DE PASTAGENS, 12., Piracicaba, 1995. Anais. Piracicaba: FEALQ, 1995. p. 129-146.

DA SILVA, S.C.; PEDREIRA, C.G.S. Fatores condicionantes e predisponentes da produção animal a pasto. In: SIMPÓSIO SOBRE MANEJO DE PASTAGENS, 13., Piracicaba, 1996. Anais. Piracicaba: FEALQ, 1997a. p. 99-121.

DA SILVA, S.C.; PEDREIRA, C.G.S. Princípios de ecologia aplicados ao manejo de pastagem. In: SIMPÓSIO SOBRE ECOSSISTEMA DE PASTAGENS, 3., Jaboticabal, 1997. Anais. Jaboticabal: FUNEP, 1997b. p. 1-62.

DA SILVA, S.C.; SBRISSIA, A.F. A planta forrageira no sistema de produção. In: SIMPÓSIO SOBRE MANEJO DE PASTAGENS, 17., Piracicaba, 2000. Anais. Piracicaba: FEALQ, 2000. p. 3-20.

DAVIES, A. The regrowth of grass swards. In: JONES, M.B.; LAZENBY, A. The grass crop: the physiological basis of production. London: Chapman and Hall, 1988. p.85-127.

DAVIES, P.J. Plant hormones: physiology, biochemistry and molecular biology. 2.ed. Boston: Kluwer Academic Press, 1995. 833p.

DAVIES, D.A.; FURTHERGILL, M.; MORGAN, C.T. Assessment of contrasting perennial ryegrasses and white clover under continuous stocking in the uplands. 5 . Herbage production, quality and intake in years 4-6. Grass and Forage Science, v. 48, n. 3, p. 213-222, 1993.

DE FARIA, V.P.; PEDREIRA, C.G.S.; SANTOS, F.A.P. Evolução do uso de pastagens para bovinos. In: SIMPÓSIO SOBRE MANEJO DE PASTAGENS, 13., Piracicaba, 1996. Anais. Piracicaba: FEALQ, 1997. p.1-14.

DONALD, C.M. Competition among crop and pasture plants. Advances in Agronomy, v. 15, p. 1-114, 1963.

DONALD; C.M.; BLACK, J.N. The significance of leaf area index in pasture growth. Herbage Abstracts, v. 28, p. 1-6, 1958.

ELLIOT, W.H.; ELLIOT, D.C. Biochemistry and molecular biology. New York: Oxford University Press, 1997. 437p. 
EMPRESA BRASILEIRA DE PESQUISA AGROPECUÁRIA. Sistema brasileiro de classificação de solos. Brasília: EMBRAPA Produção de Informação, 1999. 412p.

ENGELS, C.; MARSCHNER, H. Plant uptake and utilization of nitrogen. In: BACON, P.E. (Ed.) Nitrogen fertilization in the environment. New York: Marcel Dekker, 1995. cap.2, p.41-81.

ERNST, P.; LE DU; CARLIER, L. Animal and sward production under rotational and contiunous grazing management - a critical appraisal. In: INTERNATIONAL SYMPOSIUM OF THE EUROPEAN GRASSLAND FEDERATION ON THE ROLE OF NITROGEN IN INTENSIVE GRASSLAND PRODUCTION, Wageningen, 1980. Proceedings. Wageningen: CAPD, 1980. p.119-126.

ESCOLA SUPERIOR DE AGRICULTURA “LUIZ DE QUEIROZ”. Departamento de Ciências Exatas. http://ce.esalq.usp.br/dce/anos.htm (20 de abril de 2002).

FAGUNDES, J. L. Efeitos de intensidades de pastejo sobre o índice área foliar, interceptação luminosa e acúmulo de forragem em pastagens de Cynodon spp. Piracicaba, 1999. 69p. Dissertação (Mestrado) - Escola Superior de Agricultura "Luiz de Queiroz", Universidade de São Paulo.

FAGUNDES, J.L.; DA SILVA, S.C.; PEDREIRA, C.G.S.; SBRISSIA, A.F.; CARNEVALLI, R.A.; CARVALHO, C.A.B.; PINTO, L.F.M. Índice de área foliar, interceptação luminosa e acúmulo de forragem em pastagens de Cynodon spp. sob diferentes intensidades de pastejo. Scientia Agricola, v. 56, n.4, p.1141-1150, 1999.

FAGUNDES, J.L.; DA SILVA, S.C.; PEDREIRA, C.G.S.; CARNEVALLI, R.A.; CARVALHO, C.A.B.; SBRISSIA, A.F.; PINTO, L.F.M. Índice de área foliar, coeficiente de extinção luminosa e acúmulo de forragem em pastagens de Cynodon spp. sob lotação contínua. Pesquisa Agropecuária Brasileira, v. 36, n.1, p. 187195, 2001.

FAO. http://www.apps.fao.org/page/collections?subset $=$ agriculture. $(20 \mathrm{de}$ abril de 2002).

FELLER, U.; FISCHER, A. Nitrogen metabolism in senescing leaves. Critical Reviews in Plant Sciences, v.13, n.3, 241-273, 1994. 
FERNANDES, M.S.; ROSSIELLO, R.O.P. Mineral nitrogen in plant physiology and plant nutrition. Critical Reviews in Plant Sciences, v.14, n.2, 111-148, 1995.

FICK, G.W.; CLARK, E.A. The future of grass for dairy cattle. In: CHERNEY, J.H.; CHERNEY, D.J.R. (Ed.) Grass for dairy cattle. Wallingford: CAB International, 1998, cap.1, p.1-22.

GASTAL, F.; LEMAIRE, G. N uptake and distribution in crops: an agronomical and ecophysiological perspective. Journal of Experimental Botany, v. 53, n. 370, 789799, 2002.

GOMIDE, C.A.M.; GOMIDE, J.A.; QUEIROZ, D.S. PACIULLO, D.S.C. Fluxo de tecidos em Brachiaria decumbens. In: REUNIÃO ANUAL DA SOCIEDADE BRASILEIRA DE ZOOTECNIA, 34., Juiz de Fora, 1997. Anais. Juiz de Fora: SBZ, 1997, np.

GRANT, S.A.; BARTHRAM, G.T.; TORVELL, L.; KING, J.; ELSTON, D.A. Comparison of herbage production under continuous stocking and intermittent grazing. Grass and Forage Science, v. 43, n. 1, p. 29-39, 1988.

GRASSELLI, L.C.P.; GOMIDE, C.A. de M.; PACIULLO, D.S.C.; GOMIDE, J.A. Características morfogênicas e estruturais de um relvado de Brachiaria decumbens sob lotação contínua. . In: REUNIÃO ANUAL DA SOCIEDADE BRASILEIRA DE ZOOTECNIA, 37., Viçosa, 2000. Anais. Viçosa: SBZ, 2000, np.

GROSS, C.D. Efeitos do desfolhamento sobre os níveis das frações nitrogenadas, carboidratos e fenóis solúveis em raízes de Braquiária (Brachiaria decumbens Stapf.). Piracicaba, 1988. 97p. Dissertação (Mestrado) - Escola Superior de Agricultura "Luiz de Queiroz", Universidade de São Paulo.

HENDERSHOT, K.L.; VOLENEC, J..J. Nitrogen pools in taproots of Medicago sativa L. after defoliation. Journal of Plant Physiology, v.141, p.129-135, 1993.

HODGKINSON, K.C.; WILLIAMS; O.B. Adaptation to grazing in forage plants. In: MCIVOR, J.G.; BRAY, R.A. (Ed.) Genetic resources of forage plants. Melbourne: CSIRO, 1983. p.85-100. 
HODGSON, J. The significance of sward characteristics in the management of temperate sown pastures. In: INTERNATIONAL GRASSLAND CONGRESS, 15. Kyoto, 1985. Proceedings. Nishi-Nasuno: Japanese Society of Grassland Science, 1985. p. 63-67.

HODGSON, J. Grazing management - science into practice. New York: John Wiley; Longman Scientific \& Technical. 1990. 203p.

HODGSON, J.; DA SILVA, S.C. Options in tropical pasture management. In: REUNIÃO ANUAL DA SOCIEDADE BRASILEIRA DE ZOOTECNIA, 39.; SIMPÓSIO INTERNACIONAL DE FORRAGICULTURA, Recife: SBZ, 2002. /No prelo/

HÖRTENSTEINER, S.; FELLER, U. Nitrogen metabolism and remobilization during senescence. Journal of Experimental Botany, v.53, n.370, p.927-937, 2002.

HUMPHREYS, L.R. Tropical pastures utilisation. Cambridge: Cambridge University Press, 1991. 206p.

INSTITUTO BRASILEIRO DE GEOGRAFIA E ESTATÍSTICA. Censo agropecuário. Recenseamento geral do Brasil. Fundação Instituto Brasileiro de Geografia e Estatística. Rio de Janeiro, 1998.

JUSTES, E.; THIÉBEAU, P.; AVICE J.C.; LEMAIRE, G.; VOLENEC, J.J.; OURRY, A. Influence of summer sowing dates, $\mathrm{N}$ fertilization and irrigation on autumn VSP accumulation and dynamics of spring regrowth in alfalfa (Medicago sativa L.). Journal of Experimental Botany, v.53, p. 111-121, 2002.

KABAT, E.A.; MAYER, M.M. Nynhryn method. In: THOMAS, C.C. (Ed.) Experimental immunochemistry. 2. ed., Springfielfd: . 1967. 905p.

KANNO, T.; MACEDO, M.C.M.; EUCLIDES, V.P.B.; BONO, J.A.; SANTOS JR., J.D.G.; ROCHA, M.C.; BERETTA, L.G.R. Root biomass of five tropical grass pastures under continuous grazing in Brazilian Savannas. Grassland Science, v.45, n.1, p. 9-14, 1999. 
KELLER-GREIN, G.; MAASS, B.L.; HANSON, J. Natural variation in Brachiaria and existing germoplasm collections. In: MILES, J.W.; MASS, B.L.; VALLE, C.B. (Ed.) Brachiaria: biology, agronomy and improvement. Cali: CIAT; Campo Grande: EMBRAPA CNPGC, 1996. cap.2 p. 16-42.

KIM, T.H.; OURRY, A.; BOUCAUD, J.; LEMAIRE, G. Changes in source-sink relationship for nitrogen during regrowth of Lucerne (Medicago sativa L.) following removal of shoots. Australian Journal of Plant Physiology, v. 18, p. 593-602, 1991.

KIM, T.H.; OURRY, A.; BOUCAUD, J.; LEMAIRE, G. Partitioning of nitrogen derived from $\mathrm{N}_{2}$ fixation and reserves in nodulated Medicago sativa L. during regrowth. Journal of Experimental Botany, v.44, p. 555-562, 1993.

LARCHER, W. Physiological plant ecology. 3.ed. Berlin: Springer-Verlag, 1995. $506 p$.

LE DILY, F.; GOULAS, E.; LAINÉ, P.; LE DEUNFF, E. Patterns of development and nitrogen reserves mobilization during regrowth of defoliated clover. In: INTERNATIONAL GRASSLAND CONGRESS， 19., São Pedro， 2001. Proceedings. Piracicaba: FEALQ, 2001. p. 45-46.

LEMAIRE, G.; CHAPMAN, D. Tissue flows in grazed plant communities. In: HODGSON, J.; ILLIUS, W. (Ed.) The ecology and management of grazing systems. London: CAB International, 1996. cap.1, p.3-36.

LEMAIRE, G.; GASTAL, F. $\mathrm{N}$ uptake and distribution in plant canopies. In: LEMAIRE, G. (Ed.) Diagnosis of the nitrogen status in crops. Berlin: SpringerVerlag, 1997. cap.1, p.3-43.

LEMAIRE, G.; MILLARD, P. An ecophysiological approach to modelling resource fluxes in competing plants. Journal of Experimental Botany, n. 50, p. 15-28, 1999. LOUAHLIA, S.; MACDUFF, J.H.; OURRY, A.; HUMPHREYS, M.; BOUCAUD, J. Nitrogen reserve status affects the dynamics of nitrogen remobilization and mineral nitrogen uptake during recovery of contrasting cultivars of Lolium perenne from defoliation. New Phytologist, v. 142, p. 451-462, 1999. 
MACEDO, M.C.M. Pastagens no ecossistema Cerrados: pesquisa para o desenvolvimento sustentável. In: SIMPÓSIO SOBRE PASTAGENS NOS ECOSSISTEMAS BRASILEIROS, Brasília, 1995. Anais. Brasília: SBZ, 1995. p.28-62.

MACEDO, M.C.M. Sistemas de produção animal em pasto nas savanas tropicais da América: limitações a sustentabilidade (compact disk). In: REUNIÃO LATINOAMERICANA DE PRODUCCIÓN ANIMAL, 16.; CONGRESO URUGUAYO DE PRODUCCIÓN ANIMAL, 3., Montevideo, 2000. Anais. Argentina: Alpa, 2000.

MAY, L.H. The utilization of carbohydrate reserves in pasture plans after defoliation. Herbage Abstracts, v. 30, n. 4, p.239-245, 1960.

McILROY, R.J. Carbohydrates of grassland herbage. Herbage Abstracts, v. 37, n. 2, p.79-87, 1967.

McMAHON, C. Size and shape in biology. Science, v. 179, p. 1201-1204, 1973.

MENGEL, K.; KIRKBY, E.A. Principles of plant nutrition. 5. ed. Boston: Kluwer Academic Press, 2001. 864p.

MILLARD, P. Ecophysiology of the internal cycling of nitrogen for tree growth. Journal of Plant Nutrition and Soil Science, n. 159, p.1-10, 1996.

MITIDIERI, J. Manual de gramíneas e leguminosas para pastos tropicais. São Paulo: Nobel, 1983. 198p.

MOORE, K.J.; HATFIELD, R.D. Carbohydrates and forage quality. In: Forage quality, evaluation and utilization. Madison: ASA, CSSA, SSSA, 1994, p. 229-280.

NOQUET, C.; AVICE, J.C.; OURRY, A.; VOLENEC, J.J.; CUNNINGHAM, S.; BOUCAUD, J. Effects of environmental factors and endogenous signal on $\mathrm{N}$ uptake, $\mathrm{N}$ partioning and taproot vegetative storage protein accumulation in Medicago sativa. Australian Journal of Plant Physiology, v. 28, p.279-287, 2001.

NOVOA, R.; LOOMIS, R.S. Nitrogen and plant production. Plant and Soil, n. 58, p.177-204, 1981. 
NUNES, S.G.; BOOCK, A.; PENTEADO, M.I. de O.; GOMES, D.T. Brachiaria brizantha cv. Marandu. 2.ed. Campo Grande: EMBRAPA CNPGC, 1985. 31p. (EMBRAPA CNPGC. Documentos, 21)

NUSSIO, L.G. Volumosos para bovinos de corte em confinamento. In: PEIXOTO, A.M.; MOURA, J.C. de; DE FARIA, V.P. Confinamento de bovinos de corte. Piracicaba: FEALQ, 2000. p.85-112.

OURRY, A.; BOUCAUD, J.; SALETTE, J. Nitrogen mobilization from stubble and roots during regrowth of ryegrass. Journal of Experimental Botany , v.39, p.803$809,1988$.

OURRY, A.; BIGOT, J.; KIM, T.H.; BOUCAUD, J.; SALETTE, J. Reserve mobilisation during regrowth after cutting of forage species: quantification and physiological mechanisms in ryegrass and lucerne. In: INTERNATIONAL GRASSLAND CONGRESS, 17., New Zealand and Australia, 1993. Proceedings. Palmerston North: Keeling \& Mundy Ltd., 1993. p.121-122.

OURRY, A.; KIM, T.H.; BOUCAUD, J. Nitrogen reserve mobilization during growth of Medicago sativa L. Relationships between availability and regrowth yield. Plant Physiology, v.105, p.831-837, 1994.

PARSONS, A.J. The effects of season and management on the growth of grass swards. In: JONES, M.B.; LAZENBY, A. The grass crop: the physiological basis of production. London: Chapman and Hall, 1988. p.129-177.

PARSONS, A.J.; LEAFE, E.L.; COLLET, B.; STILES, W. The physiology of grass production under grazing. I. Characteristics of leaf and canopy photosynthesis of continuously grazed swards . Journal of Applied Ecology, v. 20, n. 1, p. 117-126, 1983a.

PARSONS, A.J.; LEAFE, E.L.; COLLET, B.; PENNING, P.D.; LEWIS, J. The physiology of grass production under grazing. II. Photosynthesis, crop growth and animal intake of continuously grazed swards. Journal of Applied Ecology, v. 20, n. 1, p. 127-139, 1983 b. 
PARSONS, A.J.; JOHNSON, I.R., WILLIAMS, J.H.H. Leaf age structure and canopy photosynthesis in rotationally and continuously grazed swards. Grass and Forage Science, v. 43, n. 1, p. 1-14, 1988a.

PARSONS, A.J.; PENNING, P.D. The effect of the duration of regrowth on photosynthesis, leaf death and the average rate of growth in a rotationally grazed sward. Grass and Forage Science, v. 43, n. 1, p. 15-28, 1988 b.

PARSONS, A.J.; JOHNSON, I.R.; HARVEY, A. Use of a model to optimize the interaction between frequency and severity of intermittent defoliation and to provide a fundamental comparison of the continuous and intermittent defoliation of grass. Grass and Forage Science, v. 43, n. 1, p. 49-59, 1988c.

PARSONS, A.J.; CHAPMAN, D.F. The principles of pasture growth and pasture utilization. In: HOPKINS, A. (Ed.) Grass - its production and utilization. Oxford: Blackwell Science, 2000. cap.3, p.31-89.

PEREIRA, J.R.A.; ROSSI Jr., P. Manual prático de avaliação nutricional de alimentos. Piracicaba: FEALQ, 1996. 34p.

PINTO, L.F.M. Dinâmica do acúmulo de matéria seca em pastagens de Cynodon spp submetidas a pastejo. Piracicaba, 2000. 124 p. Dissertação (Mestrado) - Escola Superior de Agricultura "Luiz de Queiroz", Universidade de São Paulo.

POPPI, D.P.; HUGHES, T.P.; L'HUILLIER, P.J. Intake of pasture by grazing ruminants. In: NEW ZEALAND AND SOCIETY OF ANIMAL PRODUCTION. OCCASIONAL SIMPOSIUM, 10., Hamilton, 1987. Hamilton: Lincoln College, 1987. p. 55-63.

PORTES, T.A.; CARVALHO, S.I.C.; OLIVEIRA, I.P.; KLUTHCOUSKI, J. Análise do crescimento de uma cultivar de braquiária em cultivo solteiro e consorciado com cereais. Pesquisa Agropecuária Brasileira, v.35, n.7, p.1349-1358, 2000.

RAIJ, B. van; CANTARELlA, H.; QUAGGIO, J.A.; FURLANI, A.M.C. (Ed.) Recomendações de adubação e calagem para o Estado de São Paulo. 2. ed. Campinas: Instituto Agronômico \& Fundação IAC, 1996. 258p. (Boletim Técnico, 100). 
REIS, R.A; GARCIA, J.A.; GOMIDE, J.A.; OBEID, J.A. Efeito dos regimes de corte nos níveis de carboidratos totais não estruturais do capim-braquiária (Brachiaria decumbens Stapf.). Revista da Sociedade Brasileira de Zootecnia, v.14, p.522$528,1985$.

REIS, J.C.L.; AZAMBUJA, A.A. de Frequências de corte na produção e composição botânica da forragem e índice de área foliar em Brachiaria brizantha e Brachiaria humidicola. In: REUNIÃO ANUAL DA SOCIEDADE BRASILEIRA DE ZOOTECNIA, 33., 1996, Fortaleza. Anais. Fortaleza: SBZ, 1996, p. 398-401.

RENVOIZE, S.A.; CLAYTON, W.D.; KABUYE, C.H.S. Morphology, taxonomy and natural distribution of Brachiaria (Trin.) Griseb.. In: MILES, J.W.; MASS, B.L.; VALLE, C.B. (Ed.) Brachiaria: biology, agronomy and improvement. Cali: CIAT; Campo Grande: EMBRAPA CNPGC, 1996. cap.1, p.1-15.

RICHARDS, J.H. Physiology of plants recovering from defoliation. In: BAKER, M.J. (Ed.) Grasslands for our world. Wellington: Sir Publishing, 1993. p. 46-54.

ROBSON, M.J.; RYLE, G.J.A.; WOLEDGE, J. The grass plant - its form and function. In: JONES, M.B.; LAZENBY, A. (Ed.) The grass crop: the physiological basis of production. London: Chapman and Hall, p.25-83, 1988.

RODRIGUES, L.R.A.; RODRIGUES, T.J.D. Ecofisiologia de plantas forrageiras. In: CASTRO, P.R.; FERREIRA, S.P.; YAMADA, T. (Ed.). Ecofisiologia da produção agrícola. Piracicaba: Associação Brasileira para Pesquisa da Potassa e do Fosfato, 1987. p.203-230.

RODRIGUES, L.R.A.; REIS, R.A. Bases para o estabelecimento do manejo de capins do gênero Panicum. In: SIMPÓSIO SOBRE MANEJO DE PASTAGENS, 12. Piracicaba, 1995. Anais. Piracicaba: FEALQ, 1995. p.197-217.

ROSSATO, L.; LAINÉ, P.; OURRY, A. Nitrogen storage and remobilization in Brassica napus L.. during the growth cycle: nitrogen fluxes within the plant and chnages in soluble protein patterns. Journal of Experimental Botany, v. 52, n. 361, p. $1655-1663,2001$. 
ROSSATO, L.; LE DANTEC, C.; LAINÉ, P.; OURRY, A. Nitrogen storage and remobilization in Brassica napus L.. during the growth cycle: identification, characterization and immunolocalization of a putavive taproot storage glycoprotein. Journal of Experimental Botany, v. 53, n. 367, p. 265-275, 2002a.

ROSSATO, L.; MacDUFF, J.H.; LAINÉ, P.; LE DEUNFF, E.; OURRY, A. Nitrogen storage and remobilization in Brassica napus L.. during the growth cycle: effects of methyl jasmonate on nitrate uptake, senescence, growth and VSP accumulation. Journal of Experimental Botany, v. 53, n. 371, p. 1131-1141, 2002 b.

SACKVILLE HAMILTON, N.R.; MATTHEW, C.; LEMAIRE, G. In defence of the $3 / 2$ boundary rule: a re-evaluation of self-thinning concepts and status. Annals of Botany, v.76, p.569-577, 1995.

SANO, E.E.; BARCELLOS, A.de O.; BEZERRA, H.S. Área e distribuição espacial de pastagens cultivadas no Cerrado brasileiro. Planaltina: EMBRAPA Cerrados, 1999. 21p. (EMBRAPA Cerrados. Boletim de Pesquisa, 3)

SANTOS FILHO, L.F. Seed production: perspective from the Brazilian private sector. In: MILES, J.W.; MASS, B.L.; VALLE, C.B. (Ed.) Brachiaria: biology, agronomy and improvement. Cali: CIAT; Campo Grande: EMBRAPA CNPGC, 1996, cap.9, p.141-146.

SAS INSTITUTE. http://sasdocs.ucdavis.edu. (20 de abril de 2002).

SBRISSIA, A.F.; DA SILVA, S.C. Pastejo contínuo e rotacionado: avaliação segundo um enfoque ecofisiológico de pastagens. Piracicaba: ESALQ, 1999. 43p. (Monografia apresentada na disciplina Seminários em Ciência Animal e Pastagens, nível de Pós-graduação)

SBRISSIA, A.F. Compensação tamanho/densidade populacional de perfilhos em pastagens de Cynodon spp. Piracicaba, 2000. 80 p. Dissertação (Mestrado) - Escola Superior de Agricultura "Luiz de Queiroz", Universidade de São Paulo.

SCHJOERRING, J.K.; HUSTED, S.; MÄCK, G.; MATTSSON, M. The regulation of ammonium translocation in plants. Journal of Experimental Botany, v.53, n.370, p.883-890, 2002. 
SCHNYDER, H.; DE VISSER, R. Fluxes of reserve-derived and currently assimilated carbon and nitrogen in perennial ryegrass recovering from defoliation. The regrowing tiller and its component functionally distinct zones. Plant Physiology, v.119, p.1423-1435, 1999.

SCHWINNING, S.; PARSONS, A.J. The stability of grazing systems revisited: spatial models and the role of heterogeneity. Functional Ecology, v.13, p.737-747, 1999.

SHEARD, R.W. Organic reserves and plant regrowth. In: BUTLER, G.W.; BAILEY R.W. (Ed.) Chemistry and biochemistry of herbage. London: Academic Press, 1973. cap.25, p.353-377.

SILVA, D.J. Carboidratos totais não estruturais (CTN). In: SILVA, D.J. (Ed.) Análise de alimentos (métodos químicos e biológicos). Viçosa: Imprensa Universitária, 1981. cap.13, p.104-109.

SILVEIRA, J.A.G. Interações entre assimilação de nitrogênio e o crescimento de canade-açúcar (Saccharum spp.) cultivada em condições de campo. Piracicaba, 1985. 152p. Tese (Doutorado) - Escola Superior de Agricultura "Luiz de Queiroz", Universidade de São Paulo.

SKINNER, R.H.; MORGAN, J.A.; HANSON, J.D. Carbon and nitrogen reserve mobilization following defoliation: nitrogen and elevated $\mathrm{CO}_{2}$ effects. Crop Science, v.39, p.1749-1756, 1999.

SMITH, D. Removing and analyzing total nonstructural carbohydrates from plant tissue. Wisconsin Agricultural Experiment Station Researh Report, v. 41, p.1-11, 1969. SMITH, D. The nonstructural carbohydrates. In: BUTLER, G.W.; BAILEY, R.W. Chemistry and biochemistry of herbage, London: Academic Press, 1973. p. 105155 .

SMITH, D.; PAULSEN, G.M.; RAGUSE, C.A. Extraction of total available carbohydrates from grass and legume tissue. Plant Physiology, v. 39, p. 960-962. 1964.

SNYDER, F.W.; CARLSON, G.E. Selecting for partitioning of photosynthetic products in crops. Advances in Agronomy, v.37, p.47-72, 1984. 
SOARES FILHO, C.V. Variação sazonal de parâmetros bioquímico-fisiológicos em Brachiaria decumbens estabelecida em pastagens. Piracicaba, 1991. 101p. Dissertação (Mestrado) - Escola Superior de Agricultura "Luiz de Queiroz", Universidade de São Paulo.

STITT, M.; MÜLLER, C.; MATT, P.; GIBON, Y.; CARILLO, P.; MORCUENDE, R.; SCHEIBLE, W.R.; KRAPP, A. Steps towards an integrated view of nitrogen metabolism. Journal of Experimental Botany, v. 53, n. 370, p. 959-970, 2002.

TAIZ, L.; ZEIGER, E. Plant physiology. 2. ed. Sunderland: Sinauer Associates, 1998. cap.12, p.323-345: Assimilation of mineral nutrients.

TAKEI, K.; TAKAHASHI, T.; SUGIYAMA, T.; YAMAYA, T.; SAKAKIBARA, H. Múltiple routes communicating nitrogen availability from roots to shoots: a signal transduction pathway mediated by citokinin. Journal of Experimental Botany. v. 53, n. 370, p. 971-977, 2002.

TEDESCO, M.J.; GIANELLO, C.; BISSANI, C.A.; BOHNEN, H.; VOLKWEISS, S.J. Análise de solo, plantas e outros materiais. 2. ed. Porto Alegre: UFRGS, Departamento de Solos, 1995. 174p. (UFRGS. Boletim Técnico, 5).

THOMAS, H.; STODDART, J.L. Leaf senescence. Annuals Review of Plant Physiology, v.31, p.83-111, 1980.

THORNTON, B.; MILLARD, P. Increased defoliation frequency depletes remobilization of nitrogen for leaf growth in grasses. Annals of Botany, v.80, p.8995, 1997.

THORNTON, B.; MILLARD, P.; BAUSENWEIN, U. Reserve formation and recycling of carbon and nitrogen during regrowth of defoliated plants. In: LEMAIRE, G.; HODGSON, J.; MORAES, A. de; CARVALHO, P.C.F.; NABINGER, C. Grassland ecophysiologu and grazing ecology. London: CAB International, 2000. p.85-99.

TOBIN, A.K.; YAMAYA, T. Cellular compartmentation of ammonium assimilation in rice and barley. Journal of Experimental Botany, v.52, p.591-604, 2001. 
VALLE, C.B.; EUCLIDES, V.P.B.; MACEDO, M.C.M. Características das plantas forrageiras do gênero Brachiaria. In: SIMPÓSIO SOBRE MANEJO DE PASTAGENS, 17., Piracicaba, 2000. Anais. Piracicaba: FEALQ, 2000. p. 65-108.

VERHAGEN, A. M. W.; WILSON, J. H., BRITTEN, E. J. Plant production in relation to foliage illumination. Annals of Botany, v. 27, n. 108, p. 626-640. 1963.

VICKERY, P.J. Pasture growth under grazing. In: MORLEY, F.H.W. Grazing animals. Amsterdam: Elsevier Science, 1981. p.55-77. (World Animal Science, v.B-1)

VOLENEC, J.J.; OURRY, A.; JOERN, B.C. A role for nitrogen reserves in forage regrowth and stress tolerance. Physiologia plantarum, v. 97, p. 185-193, 1996.

WADE, M.H. Factors affecting the availability of vegetative Lolium perenne to grazing dairy cows with special reference to sward characteristics, stocking rate and grazing method. Rennes, 1991. 57 p. These (Docteur) - L'Universite de Rennes.

WATSON, D.J. Comparative physiological studies on the growth of field crops. 1. Variation in net assimilation rate and leaf area between species and varieties, and within and between years. Annals of Botany, v. 11, p. 41_76, 1947.

WEINMANN, H. Total available carbohydrates in grasses and legjmes. Herbage Abstracts, v. 31, n. 4, p.255-261, 1961.

WHITE, L.M. Carbohydrate reserves of grasses: a review. Journal of Range Management, v. 26, n.1, p. 13-18, 1973.

WHITEHEAD, D.C. Nutrient elements in grassland: soil-plant-animal relatioships. Cambridge: University Press, 2000. cap.5, p.95-125: Nitrogen.

WILES, P.G.; GRAY, I.K.; KISSLING, R.C. Routine analysis of protein by Kjeldahl and Dumas methods: review and interlaboratory study using dairy products. Journal of AOAC International, v.81, n.3, p.620-632, 1998. 


\section{APÊNDICES}




\section{Apêndice 1}

\section{Metodologia para Determinação de Carboidratos Totais Não Estruturais}

\section{Extração}

1. Pesar aproximadamente $0,5 \mathrm{~g}$ de amostra moída e coloca-la em frasco de fundo redondo para ferver. Anotar o peso com quatro casas decimais.

2. Adicionar $50 \mathrm{ml}$ de ácido sulfúrico $\left(\mathrm{H}_{2} \mathrm{SO}_{4}\right) 0,2 \mathrm{~mol} \mathrm{l}^{-1}$.

3. Colocar em banho de parafina a $100^{\circ} \mathrm{C}$ por $1 \mathrm{hora}$, agitando em intervalos de 20 minutos.

4. Filtrar em papel de filtro (WHATMAN no 42) e lavar com água destilada.

5. Passar o filtrado para balão volumétrico de $250 \mathrm{ml}$.

6. Neutralizar com $10 \mathrm{ml}$ de hidróxido de sódio $(\mathrm{NaOH}) 1 \mathrm{~mol} \mathrm{l}^{-1}$.

7. Adicionar água destilada até o volume de $250 \mathrm{ml}$.

8. Agitar e usar $10 \mathrm{ml}$ de alíquota para a determinação dos com modificações dos reagentes.

\section{Titulação}

1. Pipetar $10 \mathrm{ml}$ da alíquota dentro de cada tubo teste com agitação compassada.

2. Adicionar $10 \mathrm{ml}$ da solução de sulfato de cobre $\left(\mathrm{CuSO}_{4}\right.$ - Reagente 50), tampar e agitar o frasco.

3. Colocar em banho de água fervente por 15 minutos.

4. Colocar em banho de água fria corrente por 3 minutos.

5. Adicionar $2 \mathrm{ml}$ da solução de iodeto e oxalato de potássio $\left(\mathrm{KI}-\mathrm{K}_{2} \mathrm{C}_{2} \mathrm{O}_{4}\right)$.

6. Adicionar $10 \mathrm{ml} \mathrm{de} \mathrm{H}_{2} \mathrm{SO}_{4} 1 \mathrm{~N}$ e, em seguida agitar o tubo.

7. Colocar em banho de água fria por 5 minutos.

8. Titular com tiossulfato de sódio $\left(\mathrm{Na}_{2} \mathrm{~S}_{2} \mathrm{O}_{3} 0,02 \mathrm{~mol} \mathrm{l}^{-1}\right)$ até próximo ao ponto de viaragem ("laranja claro"). 
9. Adicionar $1 \mathrm{ml}$ da solução indicadora de amido antes de atingir o ponto final (entre azul claro e verde água)

10. Registrar o volume de $\mathrm{Na}_{2} \mathrm{~S}_{2} \mathrm{O}_{3} 0,02 \mathrm{~mol} \mathrm{l}^{-1}$ utilizado.

\section{Cálculo:}

$\operatorname{CNE}\left(\mathrm{g} \mathrm{kg}^{-1}\right)=\left(\left(\mathrm{V}_{\text {branco }}-\mathrm{V}_{\text {amostra }}\right) \cdot \mathrm{f} \cdot 25\right) \cdot(\mathrm{M} \cdot 10)^{-1} \quad$, onde:

$\mathrm{V}_{\text {branco }}=$ volume de tiossulfato de sódio gasto na titulação do branco (ml)

$\mathrm{V}_{\text {amostra }}=$ volume de tiossulfato de sódio gasto na titulação da amostra (ml)

$\mathrm{F} \quad=$ fator de padronização do tiossulfato de sódio

$\mathrm{M} \quad=$ massa da $\operatorname{amostra}(\mathrm{g})$

Referência:

SILVA, D.J. Carboidratos totais não estruturais (CTN). In: SILVA, D.J. (Ed.) Análise de alimentos (métodos químicos e biológicos). Viçosa: Imprensa Universitária, 1981. cap.13, p.104-109. 


\section{Apêndice 2}

\section{Metodologia para a Determinação de Nitrogênio em Aminoácidos}

\section{Extração}

1. Pesar $100 \mathrm{mg}$ de MS moída em tubos de centrífuga com capacidade para $15 \mathrm{ml}$.

2. Acrescentar $4 \mathrm{ml}$ de etanol $80 \%$, aquecer em banho-maria na temperatura de $85^{\circ} \mathrm{C}$ por 15 minutos.

3. Calibrar os tubos e centrifugar a $3500 \mathrm{rpm}$ (correspondente a $1993 \mathrm{~g}$-Relative Centrifugal Force), por 10 minutos.

4. Manter o sobrenadante no tubo de centrífuga

5. Repetir a operação por mais 2 vezes.

6. Retirar um alíquota de $1 \mathrm{ml}$ do extrato.

\section{Reagentes}

\section{Solução de KCN 0,01 mol $\mathrm{l}^{-1}$}

1. Pesar $650 \mathrm{mg}$ de $\mathrm{KCN}$ em um Becker.

2. Dissolver com água deionizada.

3. Aferir o volume para $1000 \mathrm{ml}$.

\section{Solução de Ninhidrina}

1. Dissolver $200 \mathrm{mg}$ de ninhidrina em $15 \mathrm{ml}$ de metil celosolve (etileno glicol

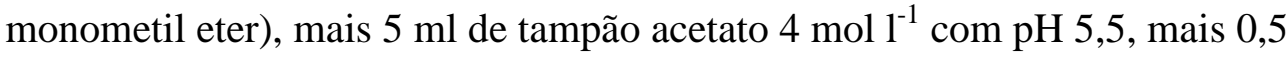
$\mathrm{ml}$ de $\mathrm{KCN}$ 0,01 $\mathrm{mol} \mathrm{l}^{-1}$.

2. Agitar, descansar 5 minutos e utilizar. Preferencialmente colocar em frasco escuro. 
3. Esta solução deve ser preparada minutos antes do uso, pois sofre perda de coloração.

\section{Tampão Acetato de Sódio 4 mol I ${ }^{-1}$ com pH 5,5}

1. Dissolver $272 \mathrm{~g}$ de $\mathrm{CH}_{3} \mathrm{COONa} .3 \mathrm{H}_{2} \mathrm{O}$ em $200 \mathrm{ml}$ de água deionizada.

2. Dissolver sob aquecimento e agitação.

3. Deixar esfriar.

4. Adicionar $50 \mathrm{ml}$ de ácido acético glacial e elevar o volume para $500 \mathrm{ml}$.

5. Ajustar o $\mathrm{pH}$ com o mesmo ácido $\left(\mathrm{CH}_{3} \mathrm{COOH}\right.$.glacial $)$.

\section{Método}

1. Tomar uma alíquota de $0,2 \mathrm{ml}$ do extrato alcoólico.

2. Adicionar $0,4 \mathrm{ml}$ da solução de ninhidrina ativada com $\mathrm{KCN}$.

3. Levar em banho-maria por 5 minutos a $100^{\circ} \mathrm{C}$.

4. Esfriar por 5 minutos em água corrente.

5. Adicionar $2 \mathrm{ml}$ de etanol $50 \%$.

6. Agitar.

7. Ler em $570 \eta \mathrm{m}$.

\section{Preparo do Branco para a Colorimetria}

1. Pipetar $0,2 \mathrm{ml}$ de etanol $80 \%, 0,4 \mathrm{ml}$ de ninhidrina e $2 \mathrm{ml}$ de etanol $50 \%$ em cada tubo representando o branco e ler em 570 ๆm.

\section{Solução Estoque para a Curva Padrão}

Pesar 111,6 mg de glicina e completar o volume a $104 \mathrm{ml}$ em balão volumétrico com o branco. A concentração da solução estoque deverá ser de $200 \mu \mathrm{g}$ ml-1 de N 


\section{Diluições para a Curva Padrão:}

Em tubos uniformes, limpos e secos com triplicatas, diluir:

\begin{tabular}{ccc}
\hline Tubos & Diluições & $\mu \mathrm{g} / \mathrm{mL}$ \\
\hline 1 & $1 \mathrm{~mL}$ de Estoque $+3 \mathrm{~mL}$ de Branco & 50 \\
2 & $1 \mathrm{~mL}$ de Estoque $+4 \mathrm{~mL}$ de Branco & 40 \\
3 & $3,5 \mathrm{~mL}$ de Estoque $+16,5 \mathrm{~mL}$ de Branco & 35 \\
4 & $3 \mathrm{~mL}$ de Estoque $+17 \mathrm{~mL}$ de Branco & 30 \\
5 & $1 \mathrm{~mL}$ de Estoque $+7 \mathrm{~mL}$ de Branco & 25 \\
6 & $1 \mathrm{~mL}$ de Estoque $+9 \mathrm{~mL}$ de Branco & 20 \\
7 & $7,5 \mathrm{~mL}$ do tubo $(6)+2,5 \mathrm{~mL}$ de Branco & 15 \\
8 & $1 \mathrm{~mL}$ de Estoque $+19 \mathrm{~mL}$ de Branco & 10 \\
9 & $7,5 \mathrm{~mL}$ do tubo $(8)+2,5 \mathrm{~mL}$ de Branco & 7,5 \\
10 & $5 \mathrm{~mL}$ do tubo $(8)+5 \mathrm{~mL}$ de Branco & 5 \\
11 & $5 \mathrm{~mL}$ do tubo $(10)+5 \mathrm{~mL}$ de Branco & 2,5 \\
12 & $5 \mathrm{~mL}$ do tubo $(11)+5 \mathrm{~mL}$ de Branco & 1,25 \\
13 & $5 \mathrm{~mL}$ do tubo $(12)+5 \mathrm{~mL}$ de Branco & 0,625 \\
14 & $5 \mathrm{~mL}$ de Branco & 0 \\
\hline
\end{tabular}

\section{Cálculo:}

ABSORBÂNCIA $=\mathrm{a}+\mathrm{b} \times \mu \mathrm{g} \mathrm{ml}{ }^{-1}$

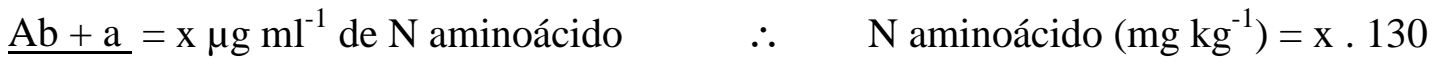
b

Referência:

KABAT, E.A.; MAYER, M.M. Nynhryn method. In: THOMAS, C.C. (Ed.) Experimental immunochemistry. 2. ed., Springfielfd: . 1967. 905p. 